\title{
AVALIAÇÃO DA RESISTÊNCIA À FRATURA DE DENTES COM CONDUTOS ALARGADOS E RECONSTRUÍDOS COM PINOS DE FIBRAS DE VIDRO PRÉ-FABRICADOS (ASSOCIADOS A PINOS ACESSÓRIOS OU FITAS DE FIBRAS) OU COM PINOS ANATÔMICOS
}

\section{Osvaldo Bazzan Kaizer}

Tese apresentada à Faculdade de Odontologia de Bauru, da Universidade de São Paulo, como parte dos requisitos para obtenção do título de Doutor em Odontologia, área de Reabilitação Oral.

(Edição Revisada) 


\section{AVALIAÇÃO DA RESISTÊNCIA À FRATURA DE DENTES COM CONDUTOS ALARGADOS E RECONSTRUÍDOS COM PINOS DE FIBRAS DE VIDRO PRÉ-FABRICADOS (ASSOCIADOS A PINOS ACESSÓRIOS OU FITAS DE FIBRAS) OU COM PINOS ANATÔMICOS}

\section{Osvaldo Bazzan Kaizer}

Tese apresentada à Faculdade de Odontologia de Bauru, da Universidade de São Paulo, como parte dos requisitos para obtenção do título de Doutor em Odontologia, área de Reabilitação Oral.

Orientador: Prof. Dr. Gerson Bonfante

(Edição Revisada) 


\section{Kaizer, Osvaldo Bazzan}

K123a Avaliação da resistência à fratura de dentes com condutos alargados e reconstruídos com pinos de fibras de vidro préfabricados (associados a pinos acessórios ou fitas de fibras) ou com pinos anatômicos / Osvaldo Bazzan Kaizer. Bauru, 2006.

xvii, 173 p. + apênd.: il.; 30 cm.

Tese (Doutorado) - - Faculdade de Odontologia de Bauru. Universidade de São Paulo.

Orientador: Prof. Dr. Gerson Bonfante.

Autorizo, exclusivamente para fins acadêmicos e científicos, a reprodução total ou parcial desta tese, por processos fotocopiadores e outros meios eletrônicos.

Assinatura:

Data de aprovação pelo Comitê de Ética da FOB/USP: 05-05-2004

Número de protocolo: 18/2004 


\section{Osvaldo Bazzan Kaizer}

\begin{tabular}{|c|c|}
\hline $\begin{array}{l}18 \text { de fevereiro de } 1973 \\
\text { Tupanciretã - RS }\end{array}$ & Nascimento \\
\hline Filiação & $\begin{array}{l}\text { Olavo Kaiser } \\
\text { Maria Lúcia Jaeger Bazzan Kaizer }\end{array}$ \\
\hline 1990-1994 & $\begin{array}{l}\text { Curso de Graduação em Odontologia pela } \\
\text { Universidade Federal de Santa Maria - RS }\end{array}$ \\
\hline 1998-1999 & $\begin{array}{l}\text { Curso de Especialização em Prótese Dentária } \\
\text { pela Universidade Luterana do Brasil - RS }\end{array}$ \\
\hline 1998 & $\begin{array}{l}\text { Professor Auxiliar de Prótese Dentária da } \\
\text { Universidade Federal de Santa Maria - RS }\end{array}$ \\
\hline 2001-2003 & $\begin{array}{l}\text { Curso de Pós-Graduação - Mestrado em } \\
\text { Reabilitação Oral, pela Faculdade de } \\
\text { Odontologia de Bauru - USP - SP }\end{array}$ \\
\hline 2003-2006 & $\begin{array}{l}\text { Curso de Pós-Graduação - Doutorado em } \\
\text { Reabilitação Oral, pela Faculdade de } \\
\text { Odontologia de Bauru - USP - SP }\end{array}$ \\
\hline Associações & $\begin{array}{l}\text { Conselho Regional de Odontologia - Seção do } \\
\text { Rio Grande do Sul }\end{array}$ \\
\hline
\end{tabular}


"Quem passou pela vida em branca nuvem E em plácido repouso adormeceu Quem não sentiu o frio da desgraça Quem passou pela vida e não sofreu, Foi espectro de homem, e não homem Só passou pela vida, e não viveu." F. O. A. Rosas 


\section{Dedico este trabalho}

Ao meu estimado pai Olavo, viga mestra em horas dificeis, por indicar o caminho correto e a conduta mais digna a seguir através de seus exemplos, bem como pelo incentivo constante para minha formação pessoal e profissional, agradeço e dedico toda minha admiração.

À minha querida mãe Maria Lúcia, pessoa muito especial e importante em minha vida, que presenteia-me sempre com as bençãos de seu amor irrestrito e de sua bondade infinita, e me acompanha tão próxima quanto possivel em todos os instantes, minha eterna gratidão.

À minha amada esposa Rosane, melhor companheira e amiga que alguém jamais poderia desejar, agradeço por seu carinho, compreensão e cumplicidade em todas as horas, pelo estimulo constante, apoio incondicional e trabalho incansável lado a lado, sem os quais mais esta etapa não teria sido vencida.

À minha irmã e grande amiga Cristina, agradeço por seu estímulo, confiança e apoio em todas as dificuldades que já enfrentei, que me servem de inspiração para continuar a buscar meus objetivos.

A Deus, razão de nossa existência. A consciência de Sua presença invisivel ao meu lado, de Sua eterna proteção e da benção de Seu amor e generosidade são motivacões permanentes. 
Ao meu orientador, Prof. Dr. Gerson Bonfante, agradeso por compartilhar comigo seus conhecimentos e sua experiência inestimáveis, os quais tão pacientemente me foram transmitidos, e pela amizade que sempre marcon nossa convivência.

Que fique aqui registrada também minha eterna gratidão por sua assistência sempre que dela necessitei e por suas palavras serenas e tranquilizadoras, bem como minha admiração por seu caráter exemplar e pela dedicação verdadeira à tudo aquilo que far: 


\section{$\boldsymbol{A}_{\text {gradecimentos }} \boldsymbol{E}_{\text {speciais }}$}

$\dot{\boldsymbol{A}}$ Faculdade de Odontologia de Santa Maria, representada por sen Coordenador Prof. Dr. Paulo Afonso Burmann, por sua dedicação para com a Faculdade e por sua firmeza de propósitos.

$\boldsymbol{A}_{\text {o }}$ Chefe do Departamento de Odontologia Restauradora da Faculdade de Odontologia de Santa Maria, Prof. Dr. Roberto Bisogno, pelo sen inestimável apoio, pelo respeito com que sempre me tratou e, acima de tudo, por sua valiosa amizade.

Ao Prof. Dr. Luiz Fernando Pegoraro e ao Prof. Dr. Paulo César Rodrigues Conti, pela permanente e incansável busca em melhorar a qualidade de nosso aprendizado durante todo o curso de Mestrado e de Doutorado e por serem exemplos de mestres e cientistas.

Ao Prof. Dr. Accácio Lins do Valle, pelo seu apoio, pelas inúmeras vezes em que me oferecen auxilio e por suas preciosas sugestões. 
$\boldsymbol{A}$ todos os professores da Faculdade de Odontologia de Santa Maria, especialmente ao Prof. Dr. Henrique Hollweg, Prof. Dra Amália Cáceres Moncada, Prof. Dra Letícia Jacques, Prof. Dr. Cláudio Figueiró, Prof. Dra Lúcia Helena Mozzaquatro, Prof. Dr. Daltro Antunes Dutra, Prof. Dr. Paulo Afonso Burmann, Prof. Dr $\boldsymbol{r}^{\mathrm{a}}$ Kátia Olmedo Braun, Prof. Paulo Antônio Pimenta, Prof. Dr. Luiz Felipe Soares e Prof. Dr. Gustavo Quesada, por sua amizade, pelo voto de confiança em mim depositado e pelas oportunidades concedidas.

Ao Prof. Dr. Ney Mugica Mutti dedico um agradecimento especial por sua assistência abnegada e altruista em momentos decisivos de minha vida, bem como por seus sempre sábios e oportunos conselhos.

$\boldsymbol{A}$ todos meus Professores na Faculdade de Odontologia de Bauru, especialmente ao Prof. Dr. Carlos dos Reis Pereira de Araújo, Prof. Dr. Milton Carlos Gonçalves Salvador, Prof. Dr. Renato de Freitas, Prof. Dr. José Henrique Rubo, Prof. Dr. Wellington Cardoso Bonachella, Prof. Dr. Accácio Lins do Valle, Prof. Dr. Luiz Fernando Pegoraro, Prof. Dr. Paulo César Rodrigues Conti, Prof. Dr. Paulo Martins Ferreira, Prof. Dr. Ricardo Marins de Carvalho, Prof. Dr. José Mondelli, Prof. Dr. Eduardo Batista Franco e Prof. Dra Lucimar Falavinha Vieira, pelo empenho e dedicação em transmitir da mais perfeita e completa forma possivel seus amplos conbecimentos. 
Aos men colegas de Mestrado e Doutorado Mauro, Paulo Henrique, Renato, Tatiany, Leylha, Stella, Renato, Rafael, Jefferson, Mariana, Luiz Gustavo, Luciana, Ana Lúcia, Paulo Fukashi, Antônio Ricardo Duarte, Eduardo Ayub, Marinelle e Marly, pelo companheirismo e pela cooperação em todas as etapas que enfrentamos juntos.

Aos meus veteranos, especialmente ao Anuar, Carlos, Nelson, William, Juliano, Vinícius, Rudys, Gildo e Stefânia, que sempre me trataram com respeito, nunca recusando auxilio on dividir suas experiências quando necessitei. O contato com cada um de vocês trouxe contribuições inestimáveis.

Aos meus "calouros" Estevan, Rodrigo, Lucas, Jonas, Andréa, Márcio, Kátia, Lívia, Patrícia, Valdey, Adriana, Ana Paula, Daniel Bayardo, Daniel Sartorelli, Fernando, Flora, Gabriela, Jefferson Tomio, Luciana Rezende, Luís Eduardo, Paola, Rafael Tobias, Romão, Thiago e Valéria, pela amizade e apoio constantes.

Aos técnicos de laboratório Reivanildo e Marcelo, pela prestez e disponibilidade na confecção de material para esta tese, pelo auxílio na execução dos projetos de pesquisa e dos trabalhos para os pacientes atendidos nas clínicas.

Aos funcionários das clínicas, especiamente à Senhora Ana Maria, à Senhora Cleusa, ao Eduardo e à Valquiria, pelo carinho, atenção e dedicaşão que tornavam mais agradáveis as aulas nas clínicas.

As funcionárias do Departamento de Prótese Edna, Cláudia e Déborah, bem como a todos os funcionários da biblioteca, especialmente à Cybelle, Rita, Valéria, César e Vera, que sempre mostraram extraordinária disponibilidade, disposição e eficiência à menor solicitação. 


\title{
Agradecimentos
}

\author{
$\dot{\boldsymbol{A}}$ Faculdade de Odontologia de Bauru - Universidade de São Paulo, representada por seu \\ diretor Prof. Dr. Luiz Fernando Pegoraro, pela oportunidade da realização de meu \\ curso de Doutorado nesta conceituada escola.
}

Ao Presidente da Comissão de Pós-Graduação, Prof. Dr. José Carlos Pereira, pelo seu constante empenho e interesse em buscar a melhoria das condições da Pós-Graduação.

Alo Prof. Dr. José Roberto Lauris, pela orientação na confecção da análise estatística do presente estudo e das demais pesquisas executadas durante o Mestrado e o Doutorado.
Als funcionários da Pós-Graduação, especialmente à Giane, Maria Margareth, Ana Letícia e Aurélio, pela pronta atenção dispensada.

Alos meus pacientes, a maioria dos quais tornaram-se também meus amigos.
$\boldsymbol{A}$ todas as pessoas que de alguma forma contribuiram, direta ou indiretamente, para a conclusão deste trabalho.




\section{SUMÁRIO}

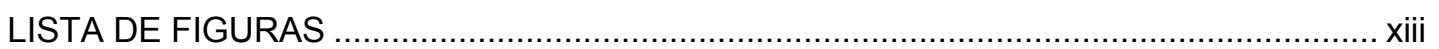

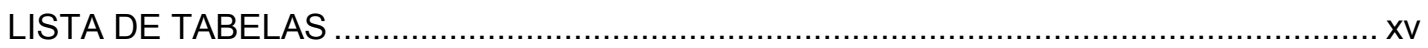

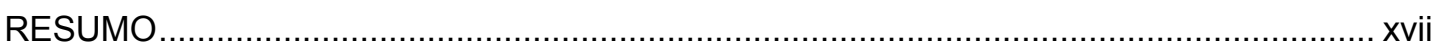

1 INTRODUÇÃO

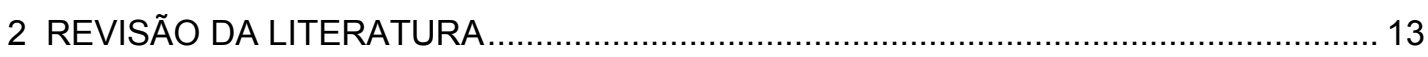

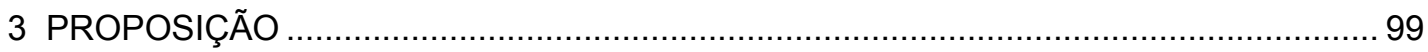

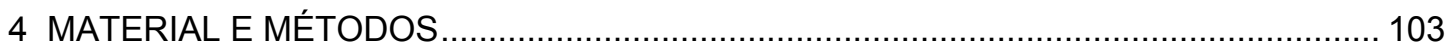

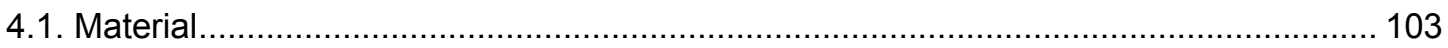

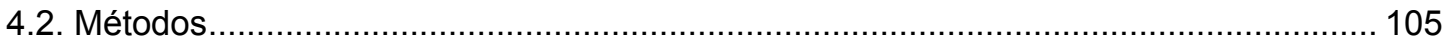

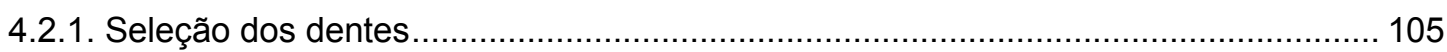

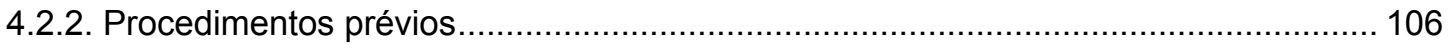

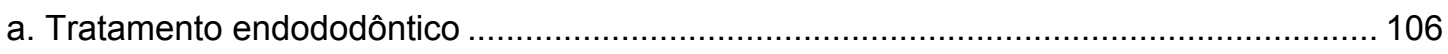

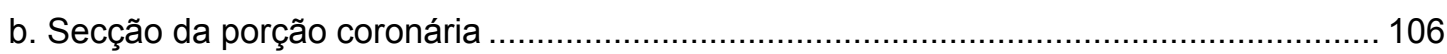

c. Fixação das raízes em cilindros plásticos ............................................................... 107

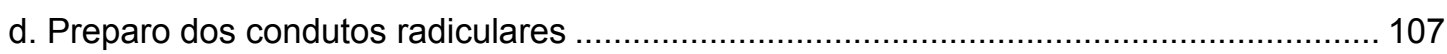

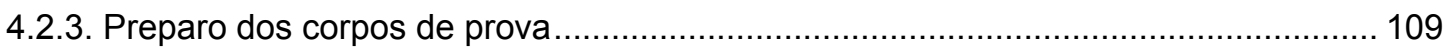

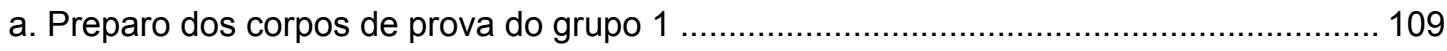

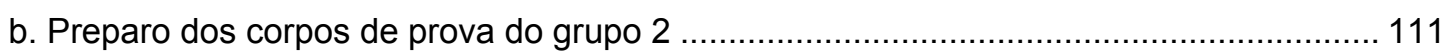

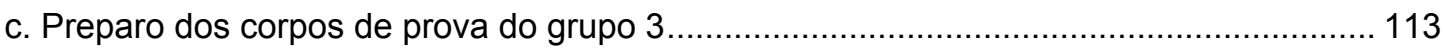

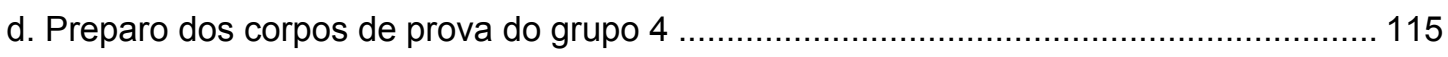

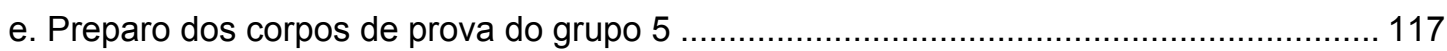

f. Confecção e cimentação de coroas totais metálicas.................................................... 119

4.2.4. Teste de resistência à fratura sob compressão .................................................... 120

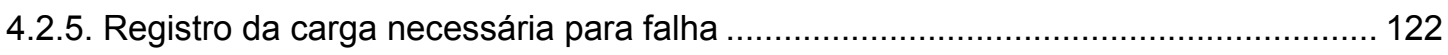

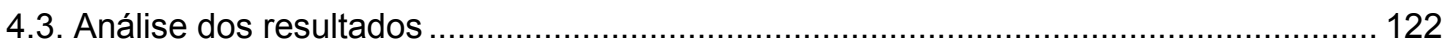

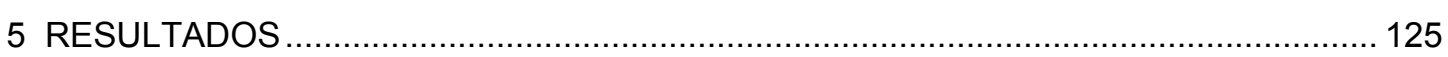

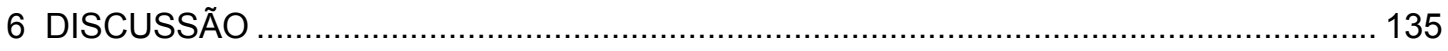

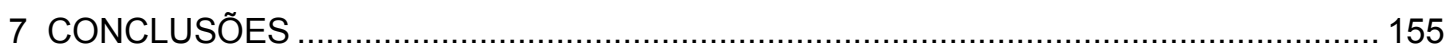

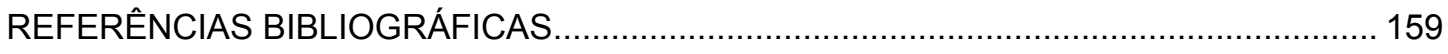

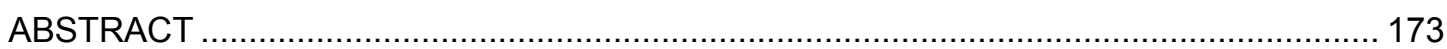

APÊNDICE 


\section{LISTA DE FIGURAS}

FIGURA 2.1- Quadro comparativo das características mais relevantes dos produtos que requerem impregnação (BOTTINO et al., 2001).

FIGURA 2.2- Quadro comparativo das características mais relevantes dos produtos pré-impregnados (BOTTINO et al., 2001).

FIGURA 2.3- Tratamento superficial aplicado nos diferentes sistemas de pinos (SAHAFI et al., 2003).

FIGURA 2.4- Tratamento superficial aplicado em cada pino (SAHAFI et al., 2004).

FIGURA 4.1- Relação do material utilizado na pesquisa e dos fabricantes ..

FIGURA 4.2- Representação esquemática dos cinco grupos

experimentais.

FIGURA 4.3. Representação esquemática da seqüência de preparo

FIGURA 4.4- Vista incisal do preparo do canal radicular utilizado para os cinco grupos.

FIGURA 4.5A- Núcleo metálico fundido cimentado no canal radicular - vista frontal

FIGURA 4.5B- Núcleo metálico fundido cimentado no canal radicular - vista lateral

FIGURA 4.6- Pino de fibras de vidro Fibrekor cimentado no canal radicular com cimento resinoso.

FIGURA 4.7- Vista frontal da porção coronária de um espécime do grupo 2 confeccionada com resina composta Enforce-Core.

FIGURA 4.8A- Confecção de um núcleo de preenchimento do grupo 3 pela associação de um pino de fibras de vidro com fitas de fibras de vidro - Fitas emergindo do conduto em torno do pino de fibras de vidro.

FIGURA 4.8B- Confecção de um núcleo de preenchimento do grupo 3 pela associação de um pino de fibras de vidro com fitas de fibras de vidro - Utilização do porta-agulha para conformação das fitas em torno do pino de fibras de vidro.

FIGURA 4.9- Preenchimento do conduto com o pino de fibras de vidro principal e três pinos de fibras de vidro acessórios (grupo 4)... 
FIGURA 4.10A- Seqüência da confecção de um pino anatômico (grupo 5) - Resina composta de baixa viscosidade sendo injetada em conduto de espécime do grupo 5 .

FIGURA 4.10B- Seqüência da confecção de um pino anatômico (grupo 5) - Complementação da polimerização do pino anatômico após sua remoção do canal radicular.....

FIGURA 4.10C- Seqüência da confecção de um pino anatômico (grupo 5) - Pino anatômico já confeccionado.

FIGURA 4.11- Representação esquemática do carregamento de compressão formando um ângulo de $45^{\circ}$ em relação ao plano horizontal $\left(135^{\circ} \mathrm{em}\right.$ relação ao longo eixo do dente)

FIGURA 4.12- Visão aproximada do carregamento de compressão formando um ângulo de $45^{\circ}$ em relação ao plano horizontal $\left(135^{\circ}\right.$ em relação ao longo eixo do dente).....

FIGURA 5.1- Gráfico representativo das médias de resistência à fratura dos grupos experimentais.

FIGURA 5.2- $\quad$ Representação gráfica do padrão de fratura observado nos grupos experimentais

FIGURA 6.1A- Tipos de fraturas mais comuns - Flexão ou fratura da porção coronária do núcleo, acompanhada de deslocamento parcial da coroa.

FIGURA 6.1B- $\quad$ Tipos de fraturas mais comuns - Fratura ao nível do terço cervical da raiz (no limite do nível ósseo simulado).

FIGURA 6.1C- Tipos de fraturas mais comuns - Fratura radicular ao nível do terço médio da raiz (abaixo do nível ósseo simulado). 


\section{LISTA DE TABELAS}

TABELA 2.1- Valores de resistência à fratura e padrões de falha para dentes tratados endodonticamente restaurados com fibras de polietileno (KARNA, 1996).

TABELA 2.2- Resistência à flexão até o limite elástico, resistência à flexão máxima e módulo de elasticidade de quatro fibras comerciais (GOLDBERG et al., 1998)

TABELA 2.3- Médias de resistência à fratura e desvios padrão para cada grupo experimental (SIRIMAI; RIIS; MORGANO, 1999).

TABELA 2.4- Resistência adesiva com oito combinações de pinos de fibras e de resinas compostas de baixa viscosidade, com ou sem a aplicação de silano (GORACCl et al., 2005).

TABELA 5.1- Valores individuais de resistência à fratura (em kgf) para cada corpo de prova, médias e respectivos desvios padrão para cada grupo experimental.

TABELA 5.2- Médias de resistência à fratura e respectivos desvios padrão em cada grupo experimental..

TABELA 5.3- Resultados da Análise de Variância a um critério (ANOVA) para o ensaio de resistência à fratura das raízes.

TABELA 5.4A- Teste de TUKEY para comparações múltiplas.

TABELA 5.4B- Teste de TUKEY para comparações múltiplas.

TABELA 5.5- Padrão de fratura observado para os grupos experimentais...

TABELA 5.6- Porcentagem de corpos de prova com padrão de fratura favorável ou desfavorável em cada grupo 


\section{RESUMO}

Avaliou-se a resistência à fratura de dentes tratados endodonticamente e reconstruídos com núcleos metálicos fundidos ou com diferentes procedimentos restauradores empregando pinos de fibras de vidro. Selecionaram-se 50 dentes caninos seccionados na junção cemento-esmalte, tratados endodonticamente e fixados em blocos de resina acrílica. Os dentes foram distribuídos aleatoriamente em cinco grupos, subdividididos de acordo com o tratamento instituído (10 espécimes cada): 1) núcleo metálico fundido com liga de $\mathrm{Ni}-\mathrm{Cr}$ (grupo controle); 2) pino de fibras de vidro convencional FibreKor $n^{\circ} 2$ (1,25mm de diâmetro); 3 ) pino de fibras de vidro envolvido por fitas de fibras de vidro (Interlig); 4) pino de fibras de vidro combinado com pinos acessórios de fibras de vidro (Reforpin); 5) pino anatômico (pino de fibras de vidro reembasado com resina composta de baixa viscosidade (Filtek Flow). O preparo do conduto nos cinco grupos simulou raízes com canais largos e foi executado de forma escalonada (dois degraus). Para este preparo, utilizou-se a ponta diamantada 1016HL (diâmetro de 1,8mm), que penetrou $10 \mathrm{~mm}$ no conduto (profundidade total de preparo do conduto). A seguir, a ponta diamantada $3017 \mathrm{HL}$ (diâmetro de $2,5 \mathrm{~mm}$ ) penetrou $5 \mathrm{~mm}$ no conduto. Realizou-se a cimentação dos pinos com sistema adesivo Scotchbond Multi-Uso Plus e cimento resinoso RelyX CRA. Coroas totais metálicas fundidas em liga de Níquel-Cromo foram cimentadas sobre a porção coronária de todos os espécimes. Os espécimes foram armazenados por 24 horas em água destilada a $37^{\circ} \mathrm{C}$ e submetidos ao teste de resistência à fratura sob compressão na máquina de ensaios universal Kratos. A carga foi aplicada em ângulo de $135^{\circ} \mathrm{com}$ o longo eixo da raiz, na velocidade de $0,5 \mathrm{~mm} / \mathrm{min}$. Os valores de resistência à fratura encontrados foram, em ordem decrescente: Grupo 1 - 110,85kgf; Grupo 4 93,88kgf; Grupo 5 - 89,34kgf; Grupo 3 - 79,07kgf; Grupo 2 - 76,04kgf, sendo que a análise estatística (ANOVA e Tukey) demonstrou diferença estatisticamente significativa $(p<0,05)$ entre o grupo 1 e o grupo 2 , bem como entre o grupo 1 e o grupo 3. Em relação ao padrão de fratura, observou-se: grupo 1 - todas as raízes fraturaram (60\% no terço médio); grupo 2 e grupo 4 - $40 \%$ de fraturas no terço cervical da raiz e 30 a $40 \%$ de falhas da porção coronária do núcleo; grupo 3 predominância de fraturas no terço cervical da raiz (60\%); grupo $5-50 \%$ das falhas na porção coronária do núcleo. 
1 INTRODUÇÃO 


\section{INTRODUÇÃO}

A restauração de dentes tratados endodonticamente tem sido exaustivamente discutida na literatura odontológica há muitas décadas. Este procedimento torna-se especialmente complexo quando os dentes envolvidos perderam toda ou uma extensa porção da estrutura coronária devido a lesões cariosas, erosão, abrasão, restaurações anteriores, traumas e pelo próprio acesso endodôntico, causando uma redução na resistência do dente às forças intraorais $^{84,85,115,129}$.

É muito freqüente a indicação de pinos intra-radiculares quando uma coroa total é necessária para a restauração de dentes despolpados ${ }^{103,115}$. A função do núcleo é, basicamente, prover retenção para a porção coronária do núcleo, a qual irá substituir a estrutura coronária perdida ${ }^{84,134}$. Se uma quantidade igual ou maior que $50 \%$ da estrutura coronária foi perdida, um núcleo intra-radicular geralmente é necessário para promover retenção para a restauração $21,67,84,85,115$.

Pesquisas recentes demonstraram que os núcleos metálicos fundidos, assim como os pinos pré-fabricados de materiais muito rígidos (metálicos e cerâmicos), além de não reforçarem o remanescente dentário, podem, na verdade, torná-lo mais susceptível à fratura ${ }^{23,52,116,121,134}$. Por outro lado, diversos estudos demonstraram que a resistência à fratura está ligada diretamente à quantidade de estrutura dental sadia remanescente $23,81,83,120,131,134$. Assim, a tendência atual é a utilização de núcleos apenas quando realmente necessário ${ }^{84,121,127,132}$. Se há suficiente estrutura dentária remanescente e uma abertura coronária conservadora, pode-se restaurar o dente despolpado sem a utilização de pinos de retenção ${ }^{85,123}$.

A busca por núcleos intra-radiculares mais estéticos e que realmente fossem capazes de reforçar a estrutura dentária impulsionou a pesquisa de núcleos não-metálicos ${ }^{36,64}$. Um dos objetivos mais almejados era a obtenção de uma restauração em monobloco, isto é, um único complexo biomecânico pela adesão entre estrutura dentária e materiais de reconstrução (pino, agente cimentante e material de preenchimento coronário) e pela utilização de materiais com propriedades mecânicas similares às da estrutura dentária remanescente ${ }^{26,27}$. Pinos não-metálicos à base de compósitos reforçados com fibras associam um elemento de alta resistência (fibras de carbono, vidro, quartzo ou polietileno) com matrizes resinosas ${ }^{40,41}$. 
Os primeiros pinos de resina reforçada por fibras que surgiram foram os pinos de fibras de carbono, idealizados por DURET ${ }^{78}$, em 1990. Posteriormente, os pinos de fibras de carbono foram recobertos com fibras de quartzo, buscando uma melhor estética ${ }^{110}$. Os pinos de fibras de vidro, especificamente, foram introduzidos em $1992^{45}$. Como os pinos de fibras de vidro foram recentemente desenvolvidos, ainda há um escasso número de estudos clínicos controlados acerca de seu desempenho a longo prazo $35,87,91$.

A partir da metade da década de 1990, pôde-se notar um visível direcionamento dos estudos na área de pinos intra-radiculares para os pinos fibroresinosos $^{87}$. O progresso destes pinos quanto à estrutura, forma e propriedades ópticas e mecânicas conseguiu resolver algumas das limitações características dos pinos metálicos, levando um número de clínicos que cresce constantemente a utilizálos. Os pinos de fibras parecem possuir a vantagem de reduzir o risco de fraturas radiculares, uma vez que em estudos clínicos e laboratoriais executados com estes pinos houve poucas ou nenhuma fratura radicular ${ }^{18,22,35,39,40,69,78,81,87,91,116,119}$. Além disso, pinos de fibras são biocompatíveis, resistentes à corrosão e fratura, e de fácil remoção ${ }^{41}$.

Apesar das óbvias vantagens estéticas proporcionadas pelos pinos cerâmicos, sua dureza e seu alto módulo de elasticidade estão associados com uma grande friabilidade do pino e maior probabilidade de fratura dentária desfavorável ${ }^{5,69,76,116}$.

Uma das principais razões do menor número de fraturas radiculares observadas com os pinos de fibras é a similaridade entre o seu módulo de elasticidade (16 a 40GPa) com o da dentina (cerca de 18GPa); além disso, os outros materiais que compõem a restauração tipo monobloco também possuem módulos de elasticidade próximos à dentina - cimentos resinosos: 6,8 a 10,8GPa e resinas compostas: 5,7 a $25 \mathrm{GPa}^{5,39,99,109}$. Devido a estas características, os pinos de fibras absorvem a maior parte do estresse e o redistribuem eqüitativamente ao longo da raiz, aumentando o limiar de carga a partir do qual inicia a ocorrência de micro-fraturas ${ }^{40,99,114}$.

A utilização de núcleos metálicos fundidos leva a um índice de fratura radicular de 2 a $4 \%{ }^{43}$, que está relacionado ao fato de que núcleos metálicos fundidos e pinos metálicos pré-fabricados possuem um módulo de elasticidade até 10 vezes 
mais alto que o da dentina, aumentando o potencial para transferir o estresse para a raiz comprometida ${ }^{35}$.

As propriedades de materiais reforçados por fibras são bem conhecidas: 1) alta resistência ao impacto; 2) amortecimento de vibrações; 3) absorção de choques; 4) maior resistência à fadiga ${ }^{99}$. No entanto, estas propriedades dependem de vários fatores: direção das fibras, quantidade de fibras por volume, impregnação das fibras na matriz resinosa, e propriedades individuais das fibras e da matriz $^{14,32}$. Segundo DRUMMOND; BAPPA ${ }^{25}$, em 2003, a adição de fibras à matriz de resina melhora suas propriedades mecânicas, como resistência à flexão, rigidez e resistência à fadiga.

Em 1990, KING; SETCHELL ${ }^{69}$ demonstraram que dentes restaurados com pinos de fibras de carbono possuíam resistência à fratura comparável àquela de dentes restaurados com pinos pré-fabricados metálicos e modo de falha mais favorável para o remanescente dentário. Este padrão de falha, bem como adequada resistência à fratura e ao deslocamento do pino, continuaram a ser observados em estudos posteriores com estes pinos, tanto in vitro $22,60,79,81,106,116$ quanto clinicamente ${ }^{39,44,78}$. As cargas necessárias para falha de dentes restaurados com pinos de fibras de carbono geralmente excedem aquelas que normalmente ocorrem clinicamente ${ }^{116}$.

As pesquisas com pinos de fibras de vidro e de quartzo evidenciaram que dentes restaurados com estes sistemas também apresentam valores clinicamente apropriados de resistência à fratura, além de, na grande maioria das situações, fraturas passíveis de reparo; são raras as fraturas longitudinais ou oblíquas se estendendo até o terço médio ou apical da raiz com estes pinos ${ }^{4,22,35,76,84,87,91,107}$. Ainda como vantagem destes pinos, deve-se observar que sua estética é superior àquela dos núcleos metálicos, especialmente quando usados em raízes fragilizadas e com paredes finas, situação em que os núcleos metálicos podem alterar a transmissão de luz através da estrutura dentária ${ }^{100,127}$.

MANNOCCI; FERRARI; WATSON ${ }^{76}$, em 1999, avaliaram o desempenho de pré-molares restaurados com pinos de fibras de quartzo, pinos de fibras de carbono-quartzo e pinos cerâmicos, recobertos com coroas de cerâmica pura. Com os pinos de fibras, as fraturas radiculares foram mais favoráveis à manutenção do remanescente dentário e em menor número que com pinos cerâmicos. 
FERRARI et al. ${ }^{35}$, em 2000, investigaram por seis anos o desempenho de 1.304 dentes restaurados com pinos de fibras de carbono, pinos de fibras de carbono-quartzo e pinos de fibras de quartzo. A taxa de falha foi de $3,2 \%$ (deslocamento de 25 pinos e 16 casos de lesão periapical). Em nenhum caso houve prejuízo ao remanescente dentário.

AKKAYAN; GÜLMEZ ${ }^{4}$, em 2002, estudaram o efeito de pinos de titânio, pinos de fibras de quartzo, pinos de fibras de vidro e pinos cerâmicos sobre a resistência à fratura e padrões de fratura de caninos endodonticamente tratados. $A$ maior resistência ocorreu com pinos de fibras de quartzo. A resistência de pinos cerâmicos e de fibras de vidro foi similar. O padrão de fratura mais favorável foi observado com os pinos de fibra de quartzo e de fibra de vidro.

MONTICELLI et al. ${ }^{87}$, em 2003, avaliaram durante dois anos o desempenho clínico de pinos de fibras de vidro em 225 pacientes com pré-molares tratados endodonticamente e restaurados com coroas de cerâmica pura. Houve oito casos $(3,5 \%)$ de deslocamento dos pinos e seis casos de lesão periapical.

NAUMANN; BLANKENSTEIN; DIETRICH ${ }^{91}$, em 2005, avaliaram 105 dentes restaurados com pinos de fibras de vidro aos 24 meses. A maioria não possuía remanescente coronário e muitos tinham condutos alargados. Uma raiz sofreu fratura não reparável, houve falha adesiva da porção coronária de um núcleo, dois pinos deslocaram e sete fraturaram (11,4\% das restaurações falharam).

A maioria dos métodos utilizados para aumentar a retenção dos núcleos enfraquece a estrutura radicular já comprometida, aumentando a tendência da raiz à fratura $^{67}$. Alargamento excessivo do conduto para inserção de pinos de grande diâmetro debilita a raiz, que fica mais susceptível a fraturas sob cargas funcionais. Uma vez que a resistência à fratura da raiz está diretamente relacionada com o volume de dentina remanescente ${ }^{83,131}$, o conduto deve ser alargado apenas 0 suficiente para proporcionar retenção e resistência suficiente para o núcleo. Raízes restauradas com pinos de menor diâmetro são mais resistentes à fratura que aquelas com pinos mais largos ${ }^{132}$.

Técnicas restauradoras com núcleos tornam-se dificultadas ou mesmo inviáveis quando a raiz exibe amplo alargamento devido a extenso envolvimento por lesões cariosas, restauração prévia com núcleos de diâmetro excessivo, causas 
iatrogênicas (durante o acesso para tratamento endodôntico, super-instrumentação), desenvolvimento incompleto (devido a impactos traumáticos), reabsorção interna ou anomalias de desenvolvimento ${ }^{92}$. Em canais alargados, núcleos metálicos fundidos produzem efeito de cunha e pinos pré-fabricados adaptam-se imprecisamente, obrigando o operador a utilizar quantidades excessivas de cimento para substituir a estrutura perdida ${ }^{57}$. Se não reforçadas, raízes com paredes finas são altamente sujeitas à fratura durante cimentação dos pinos ou função subseqüente. Por esta razão, raízes debilitadas são rotineiramente condenadas à extração ${ }^{67,74,75,114}$.

Uma forma adequada para reforçar dentes tratados endodonticamente e com condutos amplos tem sido pesquisada, visando evitar sua perda prematura. Diferentes materiais foram testados, como ionômero de vidro ${ }^{120,133}$ e resina composta $^{74,75,80,114,120,133}$, com maior sucesso para a última. Na década de 1990, surgiu a proposta da confecção de pinos dentários para reconstituição de raízes enfraquecidas, a partir de dentes naturais obtidos em bancos de dentes, cujo resultado, tanto ao nível laboratorial quanto clínico, tem sido muito promissor ${ }^{13,62}$.

Ainda na mesma década, foi sugerida a utilização de fibras de polietileno para confecção de núcleos intra-radiculares diretamente no conduto $^{41,65,82,117,119}$. Diversos ensaios laboratoriais e estudos clínicos $^{62,63,65,67,68,82,86,92,119}$ indicaram que esta forma de reconstrução de dentes despolpados apresenta comportamento mecânico e padrão de fratura similar ao de pinos de fibras pré-fabricados, podendo ser bem aplicada em dentes com condutos amplos. São mais indicadas as fibras de polietileno com tratamento superficial por plasma de gás frio, que permite união química às resinas compostas $43,44,57,59,81,82,91$, e com arquitetura entrelaçada, que possibilita reforço multidirecional da resina e melhor distribuição do estresse $\mathrm{u}^{41,62,63,65,67,68,82,119}$.

Também fibras de vidro em forma de fitas têm sido utilizadas para confecção de pinos intra-radiculares diretamente no canal radicular ${ }^{61,95,96,97}$, pois sua facilidade de manuseio, associada à utilização de materiais de uso rotineiro (resinas compostas e cimentos resinosos) facilita a reconstrução dental, abrevia o tempo do tratamento e elimina a etapa laboratorial. Foram recomendados estudos criteriosos para observação de resultados a longo prazo com esta técnica restauradora, cuja principal indicação são as raízes com paredes enfraquecidas ${ }^{96}$. 
Uma das mais novas alternativas para a restauração de condutos alargados é a utilização de pinos pré-fabricados de fibras envolvidos por fitas de fibras $^{67,68,119}$ para melhor preenchimento de espaços vazios no conduto (causados por adaptação imprecisa do pino), possibilitando minimizar a quantidade de cimento em torno do pino. Apesar da publicação de relatos clínicos sobre este procedimento, ainda há poucas evidências científicas que o suportem ${ }^{92}$.

Outra proposta recente (que tem o mesmo objetivo de preenchimento de lacunas no canal radicular) é a inserção de pinos acessórios em torno do pino de fibras de vidro principal. Apesar disso, também são escassas na literatura as pesquisas demonstrando a efetividade desta técnica ${ }^{16,32,33}$. O trabalho de BRAZ et al. ${ }^{16}$, em 2005, avaliou a resistência à fratura de raízes com condutos alargados e restaurados com pino de fibras de vidro cimentado com cimento resinoso; com pino de fibras de vidro cimentado com resina composta para núcleos de preenchimento; ou com um pino de fibras de vidro combinado com três pinos acessórios. Observou-se a maior resistência à fratura com o emprego dos pinos acessórios.

Finalmente, GRANDINI, em $2003^{49,50}$, recomendou a adaptação do pino de fibras de vidro pré-fabricado ao canal alargado pelo reembasamento do pino com resina composta, obtendo-se um "pino anatômico" que reproduz a morfologia do conduto, proporciona uma delgada espessura de cimento entre pino e parede do conduto, favorece a retenção do pino e previne falhas adesivas. Além disso, a técnica dispensa envolvimento laboratorial. Segundo GRANDINI; SAPIO; SIMONETTI ${ }^{50}$, em 2003, o pino anatômico deve ser utilizado como rotina clínica para condutos alargados ou com anatomia irregular, podendo ser indicado sempre que a adaptação do pino pré-fabricado for imperfeita. Foi verificado, através de microscopia eletrônica de varredura, que com pinos anatômicos a espessura de cimento é seis vezes menor que com pinos pré-fabricados, havendo redução significativa do número e dimensão de micro-bolhas no cimento ${ }^{49}$. A eficácia da técnica deve ser avaliada em estudos clínicos longitudinais, inexistentes até o momento ${ }^{50}$.

A realização de estudos laboratoriais sobre os novos procedimentos restauradores propostos com pinos de fibras de vidro (pinos de fibras pré-fabricados utilizados em conjunto com pinos acessórios ou com fitas de fibras de vidro, ou ainda o pino anatômico) possibilitará o uso clínico destas opções de forma menos empírica e mais segura. Assim, esta pesquisa se justifica pela necessidade de testar a resistência 
à fratura e o padrão de falha de dentes tratados endodonticamente com condutos alargados e reconstruídos com pinos de fibras de vidro, aplicando-se diferentes modalidades restauradoras. 
2 REVISÃO DA LITERATURA 


\section{REVISÃO DA LITERATURA}

Os primeiros registros oficiais da utilização de retentores intraradiculares foram publicados no ano de 1728 por PIERRE FAUCHARD ${ }^{31}$ apud RING ${ }^{108}$, em 1989, que descreveu uma técnica de confecção de coroas retidas por um pino de madeira inserido no conduto radicular. Com a umidade, o pino expandia-se, retendo as coroas. Em meados de 1880 , teve início a utilização das coroas de Richmond, também conhecidas como "pivots", nas quais um pino metálico intraradicular formava uma peça única com a coroa. A partir da década de 1960, as coroas "pivots" foram gradualmente abandonadas, devido à dificuldade para obtenção de paralelismo entre os pilares de próteses parciais fixas, que tinha de ser obtido à custa das paredes dos condutos e também devido ao alto risco de fratura na remoção dos pinos.

Tornou-se então mais rotineira a utilização dos núcleos metálicos fundidos, confeccionados separadamente da coroa. O núcleo metálico fundido é constituído de um pino intra-radicular, fixado no conduto previamente preparado, e de uma porção que reconstitui a porção coronária, como se o dente estivesse preparado para receber uma coroa total. A coroa é cimentada sobre a porção coronária do núcleo. Os núcleos metálicos fundidos podem ser obtidos em metais nobres, nãonobres ou seminobres, a partir de padrões de resina acrílica ou de cera confeccionados diretamente na boca do paciente ou indiretamente, em modelos de gesso dos preparos dentários ${ }^{115}$.

Com a evolução dos materiais dentários nas últimas décadas, foram surgindo inúmeros sistemas de pinos metálicos pré-fabricados, com desenho, diâmetro, comprimento e textura de superfície previamente determinados, podendo ser ativos (rosqueados no interior do conduto) ou passivos (somente cimentados). Podem também ser classificados pela forma geométrica (cônicos ou paralelos) ou pela textura de superfície (lisos ou serrilhados) ${ }^{2,115}$.

Mais recentemente, tem-se procurado desenvolver sistemas de pinos intra-radiculares que consigam realmente reforçar a estrutura dentária debilitada, sem aumentar o risco de fratura do remanescente dentário e que não interfiram deleteriamente com a estética. Desta forma, houve um enorme impulso na pesquisa de núcleos não-metálicos, especialmente dos pinos de resina reforçados por fibras. 
Atualmente, busca-se a obtenção de um único complexo biomecânico (restauração em monobloco) pela adesão entre os materiais utilizados para reconstrução dentária (pino, agente cimentante e material de preenchimento coronário) e a estrutura dentária, sendo que estes mesmos materiais idealmente devem apresentar propriedades mecânicas semelhantes às da estrutura dentária remanescente ${ }^{40,41}$.

SILVERSTEIN ${ }^{118}$, em 1964, recomendou a utilização de núcleos metálicos fundidos para reforço de dentes despolpados com perdas importantes de estrutura, que seriam frágeis e mais predispostos à fratura, visando assim evitar fraturas dentárias horizontais ou longitudinais. Apresentou diversas técnicas para obtenção de núcleos em dentes anteriores e posteriores e afirmou que o núcleo metálico fundido é mais vantajoso que a coroa "pivot", porquê: (1) coroa e pino são independentes, facilitando reparos e trocas da coroa; e (2) é mais fácil a obtenção de paralelismo entre os dentes pilares de uma prótese fixa, sem desgastes excessivos das raízes.

Em 1967, BARABAN ${ }^{8}$ afirmou que dentes despolpados são mais frágeis devido à desidratação, devendo ser protegidos contra fraturas. Descreveu vários métodos para obtenção desta proteção, como: núcleos metálicos fundidos, associados ou não a pinos dentinários auxiliares; núcleos divididos; pinos metálicos préfabricados, entre outros. Afirmou que três fatores influenciam na seleção do método: 1) quantidade de coroa clínica remanescente; 2) finalidade para a qual o dente será utilizado; e 3) oclusão e hábitos oclusais do indivíduo.

Em 1970, BARABAN ${ }^{9}$ descreveu os pinos pré-fabricados metálicos Para-Post, indicados para a técnica direta (com resina acrílica para a porção coronária) ou indireta (fundido). O conduto era preparado com uma broca de tamanho similar ao do pino. Os pinos eram fornecidos em cinco tamanhos e quatro materiais diferentes (ouro, aço inoxidável, alumínio e plástico). O autor observou que a técnica era simples, e que o sistema poderia ser utilizado na maioria dos dentes unirradiculares, em sessão única.

STANDLEE et al. $^{126}$, em 1972, através de análise fotoelástica, investigaram a distribuição do estresse nas estruturas de suporte por pinos metálicos pré-fabricados com diferentes desenhos, durante a cimentação e sob cargas de cisalhamento e compressão. As formas de pinos utilizadas foram: 1) pinos cônicos lisos (1,4mm de diâmetro); 2) pinos paralelos e lisos (1,4mm de diâmetro); 3 ) pinos 
rosqueados (1,5mm de diâmetro). Testaram-se três comprimentos de cada pino: $4 \mathrm{~mm}$, $7 \mathrm{~mm}$ e $10 \mathrm{~mm}$. Simularam-se raízes de incisivos centrais superiores em modelos fotoelásticos e cimentaram-se os pinos nos condutos artificiais com fosfato de zinco. Sobre os pinos cimentaram-se coroas metálicas fundidas. Com a aplicação da carga, a concentração de estresse foi maior com pinos de menor comprimento. Concluiu-se que o comprimento do pino deve ser igual ou maior do que o comprimento da coroa anatômica. Recomendaram confecção de sulcos em pinos paralelos longos para reduzir a pressão durante a cimentação. Pinos rosqueados devem ser utilizados com precaução para evitar fraturas radiculares, devido ao alto estresse quando não adaptados adequadamente.

BARABAN $^{10}$, em 1972, descreveu a confecção de núcleos com resina composta autopolimerizável retida por pinos metálicos Para-Post, associados ou não a pinos dentinários auxiliares T.M.S. As vantagens da técnica seriam: economia de tempo; baixo custo; preparo imediato mesmo com pouco ou nenhum remanescente coronário; confecção simplificada da coroa provisória; e adequada retenção da resina ao remanescente dentário.

CAPUTO; STANDLEE ${ }^{19}$, em 1976, afirmaram que núcleos e/ou pinos devem ser utilizados quando o remanescente coronário é insuficiente para retenção da restauração, pois auxiliam na resistência ao deslocamento por forças mastigatórias. Observaram, porém, que núcleos ou pinos dentinários não reforçam as restaurações, mas na verdade as enfraquecem. Os pinos dentinários auxiliares têm sua principal utilização em dentes vitais; a retenção é maior quando mais pinos são utilizados e quando não são paralelos entre si. Observaram que: pinos pré-fabricados, quando inseridos em condutos precisamente preparados, exibem melhor performance que núcleos metálicos fundidos; pinos paralelos são mais retentivos e distribuem melhor o estresse que os cônicos (que causam efeito de cunha); pinos rosqueados são os que geram maior estresse na dentina. Pinos retidos por friç̧ão possuem retenção intermediária e os cimentados possuem a menor retenção. Pinos de grandes diâmetros devem ser evitados, pois debilitam a raiz; deve-se manter pelo menos $1 \mathrm{~mm}$ de dentina sadia em torno do pino. O comprimento intra-radicular do pino deve ser igual ou maior que o da coroa clínica para retenção adequada.

TRABERT; CAPUTO; ABOU-RASS ${ }^{132}$, em 1978, investigaram a resistência à fratura de incisivos centrais superiores, distribuídos em três grupos: 1) 
sem tratamento endodôntico ou restaurador; 2) com tratamento endodôntico somente; 3) com tratamento endodôntico e pino de aço inoxidável paralelo e serrilhado (ParaPost). Em cada grupo, testaram-se dentes com três comprimentos de raízes: $11 \mathrm{~mm}$, $13 \mathrm{~mm}$ e $15 \mathrm{~mm}$. Nos grupos 2 e 3 , prepararam-se os condutos com dois diâmetros diferentes: $1,4 \mathrm{~mm}$ e $1,8 \mathrm{~mm}$. No grupo 3 , utilizaram-se pinos de $1,2 \mathrm{~mm}$ e de $1,7 \mathrm{~mm}$. A abertura da câmara coronária foi selada com resina composta. Não houve diferença estatística significativa entre dentes não tratados ou tratados endodonticamente, e nem entre os preparos com diferentes diâmetros. A resistência à fratura aumentou com pinos de menor diâmetro e raízes de maior comprimento.

GUZY; NICHOLLS ${ }^{52}$, em 1979, observaram que dentes despolpados pareciam mais friáveis que dentes vitais, pois fraturam com freqüência durante a função. Embora a literatura recomendasse reforçar estes dentes com núcleos intraradiculares, até aquele momento a afirmação não possuía suporte científico. Assim, compararam a resistência à fratura de dentes tratados endodonticamente com e sem pinos para determinar se estes reforçam as raízes. Utilizaram 59 incisivos centrais superiores e caninos inferiores divididos em quatro grupos: caninos com e sem pinos, e incisivos centrais com e sem pinos. Nos grupos com pinos, removeu-se a obturação até $5 \mathrm{~mm}$ do ápice e cimentaram-se pinos pré-fabricados Endo-Post com fosfato de zinco. Cortaram-se os pinos $1 \mathrm{~mm}$ abaixo do acesso endodôntico, que foi restaurado com silicato. Fixaram-se os dentes ( $2 \mathrm{~mm}$ abaixo da junção cemento-esmalte) em blocos de resina acrílica. Aplicaram-se cargas compressivas sobre os dentes (de lingual para vestibular) na máquina de ensaios, a um ângulo de $130^{\circ} \mathrm{com}$ seu longo eixo, na velocidade de $5 \mathrm{~cm} / \mathrm{min}$. Não houve diferença estatística significativa no padrão de fratura (58 dentes fraturaram no terço médio ou cervical da raiz) ou na resistência à fratura entre dentes com e sem pinos. Como as falhas se iniciaram na face vestibular ou lingual das raízes, concluiu-se que o pino, por sua posição, recebe estresse mínimo, reforçando muito pouco a raiz sob cargas externas; e que quanto mais larga a dimensão vestíbulo-lingual da raiz, maior sua resistência à fratura.

SORENSEN; MARTINOFF ${ }^{124}$, em 1984, avaliaram 1273 dentes tratados endodonticamente com ou sem pinos metálicos intra-radiculares (um a 25 anos de tratamento) para estabelecer correlação com as taxas de sucesso clínico. Dividiram os dentes em seis grupos: anteriores superiores, pré-molares superiores, molares superiores, anteriores inferiores, pré-molares inferiores e molares inferiores. A utilização de núcleos intra-radiculares não aumentou significativamente a resistência à 
fratura em nenhum grupo em relação aos dentes sem pinos. Os autores sugeriram que pinos metálicos não devem ser usados rotineiramente, pois não parecem capazes de reforçar o remanescente dentário ou substituir a estrutura perdida.

Ainda em 1984, utilizando a mesma amostra acima, SORENSEN; MARTINOFF ${ }^{123}$ pesquisaram a relação entre desenho, configuração de superfície e comprimento dos núcleos com a taxa de sucesso clínico. Os sistemas que mostraram as maiores taxas de sucesso foram pinos paralelos e serrilhados (Para-Post) com porção coronária fundida $(100 \%)$ e pinos Para-Post com porção coronária em amálgama ou resina composta $(97,7 \%)$. Dentes com núcleos metálicos fundidos cônicos exibiram menor taxa de sucesso $(87,3 \%)$ que dentes sem reforço intraradicular $(89,9 \%)$. Além disso, os dentes com pinos Para-Post não falharam por fratura radicular, enquanto cerca de um terço dos dentes com núcleos metálicos fundidos foram extraídos devido a fraturas radiculares não-restauráveis. Com pinos de comprimento igual ou maior que o da coroa, o sucesso foi de mais de $97 \%$.

TROPE; MALTZ; TRONSTAND ${ }^{134}$, em 1985, compararam a resistência à fratura de 64 incisivos centrais superiores tratados endodonticamente e restaurados por oito métodos diferentes. Distribuiram os dentes em oito grupos: grupo 1 - acesso palatino preenchido com resina composta autopolimerizável, sem condicionamento ácido; grupo 2 - acesso preenchido com resina composta após condicionamento ácido; grupo 3 - conduto desobturado até $10 \mathrm{~mm}$ abaixo da junção cemento-esmalte (JCE) e preenchimento do acesso e conduto com resina composta após condicionamento ácido; grupo 4 - preparo do conduto com broca Para-Post de 1,25mm de diâmetro até $10 \mathrm{~mm}$ abaixo da JCE, sendo o conduto mantido vazio e o acesso preenchido com resina composta; grupo 5 - conduto preparado como no grupo 4 , preenchendo-se o acesso e o conduto com resina composta, sem condicionamento ácido; grupo 6 conduto preparado como no grupo 4, condicionamento ácido do conduto e acesso, cimentação de pino de aço Para-Post $(1,25 \mathrm{~mm}$ de diâmetro) com fosfato de zinco e preenchimento do acesso com resina composta; grupo 7 - conduto preparado como no grupo 4, condicionamento ácido e preenchimento do acesso e do conduto com resina composta; grupo 8 - conduto preparado como no grupo 4, condicionamento ácido e cimentação de pino Para-Post com resina composta, usada também para preencher a cavidade de acesso. Os dentes foram fixados em anéis de cobre ao nível da JCE e sujeitos à compressão na máquina de ensaios universal, em ângulo de $50^{\circ}$ com o longo eixo do dente. Todos os dentes fraturaram de modo similar, 
independentemente da técnica restauradora. Os grupos com melhor resistência à fratura foram os grupos 1, 2 e 3, sem diferenças significativas entre si. O preparo do conduto (grupos 4 a 7) enfraqueceu significativamente os dentes. Quando o pino ParaPost foi cimentado com fosfato de zinco (grupo 5) ou resina (grupo 8), os valores foram significativamente mais altos que quando o conduto preparado foi mantido vazio (grupo 4) ou preenchido com resina composta sem condicionamento ácido (grupo 5), mas significativamente mais baixos que em dentes sem preparo do conduto (grupos 1 a 3). Quando o conduto preparado e o acesso endodôntico foram condicionados e preenchidos com resina (grupo 7), a resistência à fratura foi similar aos grupos 1 a 3 (sem preparo do conduto). Indicaram a técnica usada no grupo 7 para restauração de dentes jovens tratados endodonticamente com rizogênese incompleta (condutos largos e paredes da raiz finas). Recomendaram que se evite o preparo do conduto quando possível, usando pinos somente se necessário para retenção da restauração.

TJAN; WHANG ${ }^{131}$, em 1985, avaliaram a influência da espessura da parede vestibular da raiz sobre a resistência à fratura dentária. Cimentaram núcleos metálicos fundidos em 40 incisivos centrais superiores preparados de forma que a espessura de dentina vestibular da raiz fosse de $1 \mathrm{~mm}$ (grupo 1), $2 \mathrm{~mm}$ (grupo 2), $3 \mathrm{~mm}$ (grupo 3) ou $1 \mathrm{~mm}$ com bisel de $60^{\circ}$ para formação de colar metálico (grupo 4). Submeteram-se as raízes à carga de compressão horizontal na máquina de ensaios. Não se registraram diferenças significativas na resistência à fratura entre os quatro grupos, mas houve diferenças no padrão de falhas de acordo com a espessura da parede da raiz: no grupo 1 todas as raízes fraturaram; no grupo 2 fraturaram oito raízes; no grupo 3 apenas duas raízes fraturaram; no grupo 4 fraturaram sete raízes. O colar metálico no grupo 4 não aumentou a resistência à fratura.

$\mathrm{LUI}^{74}$, em 1987, sugeriu uma técnica para reforço de raízes debilitadas, preenchendo-as internamente com resina composta. Após tratamento endodôntico e eliminação da porção coronária sem suporte, preparava-se o conduto com uma broca de tamanho compatível. Verificava-se no conduto a adaptação de um pino de tamanho similar ao da broca. Sulcos eram feitos com brocas tipo cone invertido nas paredes mais espessas da raiz. Seguia-se condicionamento com ácido fosfórico e aplicação do sistema adesivo. Inseria-se o pino lubrificado com vaselina no conduto e em torno dele era injetada e condensada resina composta. Após a polimerização o pino era removido, formando o espaço para o núcleo. Terminava-se o preparo com brocas diamantadas e, para evitar rotação do núcleo, executava-se uma cavidade elíptica de 
2 a $3 \mathrm{~mm}$ de profundidade na porção cervical do conduto. A técnica permitiria a formação de um conduto retentivo e capaz de suportar um núcleo metálico fundido, evitando fratura de raízes enfraquecidas durante cimentação ou função mastigatória.

BARKHORDAR; RADSKE; ABBASI ${ }^{11}$, em 1989, avaliaram o efeito de núcleos metálicos fundidos com colar metálico de $2 \mathrm{~mm}$ de altura sobre a resistência à fratura de dentes tratados endodonticamente. No grupo 1, utilizaram 10 incisivos centrais superiores restaurados com núcleos possuindo colar metálico e no grupo 2 utilizaram-se 10 incisivos centrais superiores com núcleos sem colar. Aplicaram cargas de compressão na superfície palatina dos núcleos, à velocidade de $0,5 \mathrm{~cm} / \mathrm{min}$ e em ângulo de $135^{\circ} \mathrm{com}$ o plano horizontal. Raízes com núcleos possuindo férula exibiram resistência significativamente maior que aquelas com núcleos sem férula.

SORENSEN; ENGELMAN ${ }^{122}$, em 1990, buscaram determinar o efeito de diferentes desenhos de pinos e do grau de adaptação do pino ao conduto na resistência à fratura dentária. Utilizaram 40 incisivos centrais superiores (quatro grupos de 10 dentes). Após tratamento endodôntico, prepararam-se os condutos com brocas Peeso $n^{0} 3$ e removeram-se as coroas. Nos grupos 1 a 3 , os condutos foram preparados de forma cônica, mantendo-se $1 \mathrm{~mm}$ de espessura da parede axial dos condutos na porção cervical da raiz. No grupo 4, o conduto não foi tornado cônico e sua parede axial permaneceu com $2,5 \mathrm{~mm}$ de espessura na porção cervical da raiz. A partir de pinos Para-Post paralelos e calcináveis, fundiram-se núcleos de pratapaládio. No grupo 1, utilizou-se apenas pino Para-Post sem reembasamento, de modo que após cimentação este ficou envolvido por grande volume de cimento e adaptado somente no terço apical. No grupo 2, reembasou-se o pino para obtenção de núcleo cônico totalmente adaptado ao conduto. No grupo 3, reembasaram-se apenas os $2 \mathrm{~mm}$ mais cervicais do pino (adaptação parcial). No grupo 4, utilizou-se apenas o pino ParaPost (máxima adaptação). Cimentaram-se coroas metálicas sobre os núcleos e fixaram-se os dentes em blocos de resina acrílica com $2 \mathrm{~mm}$ da estrutura dentária acima da resina. Aplicaram-se cargas de compressão em ângulo de $135^{\circ} \mathrm{com}$ o longo eixo da raiz, à velocidade de $2,5 \mathrm{~mm} / \mathrm{min}$. A força necessária para falha foi (ordem decrescente): grupo 2 - 49,58kgf; grupo 3- 29,47kgf; grupo 4- 28,89kgf; e grupo 122,48kgf. O grupo 2 (pinos cônicos totalmente adaptados) foi significativamente mais resistente que os demais, porém foi significativamente maior a quantidade de fraturas radiculares extensas que condenariam estes dentes à extração. Nos grupos 2 e 3 (pinos cônicos total ou parcialmente adaptados), 17 dos 20 dentes fraturaram. Já nos 
grupos 1 e 4 (somente Para-Post com paredes paralelas), 50\% ou menos das raízes fraturaram, com menor envolvimento de estrutura dentária. Apesar da camada mais espessa de cimento e da menor espessura de dentina no grupo 1 em relação ao grupo 4, não houve diferença significativa entre eles.

Ainda no mesmo ano, SORENSEN; ENGELMAN ${ }^{121}$ examinaram o efeito de vários desenhos de férulas sobre a resistência à fratura de dentes despolpados com quantidades variáveis de remanescente coronário. Prepararam-se os condutos de 60 incisivos centrais superiores (distribuídos em 6 grupos) com brocas Peeso $\mathrm{n}^{0} 4$ até $4 \mathrm{~mm}$ do ápice e cimentaram-se pinos de aço Para-Post. No grupo 1 , preparou-se ombro de $90^{\circ}$ e removeu-se toda a estrutura coronária; o conduto foi alargado, mantendo-se $1 \mathrm{~mm}$ de espessura da parede axial ao nível cervical. $\mathrm{O}$ grupo 2 foi preparado da mesma forma, mas sem alargamento do conduto. No grupo 3 preparou-se um chanfro em $130^{\circ}$ e removeu-se toda a coroa. Nos grupos 4,5 e 6 , prepararam-se um ombro de $90^{\circ}$ e um bisel de $1 \mathrm{~mm}$ de largura no término, com $60^{\circ}$ de inclinação. No grupo 4, removeu-se toda a coroa. No grupo 5 , manteve-se $1 \mathrm{~mm}$ de altura da dentina coronária e a união entre porção coronária do núcleo e estrutura dentária foi topo a topo. No grupo 6 , além de manutenção de $2 \mathrm{~mm}$ da dentina coronária, a união entre porção coronária do núcleo e estrutura dentária foi através de contra-bisel de $60^{\circ} \mathrm{com} 1 \mathrm{~mm}$ de largura. Obteve-se o padrão do núcleo a partir de um pino Para-Post $n^{0} 4$ calcinável. Executaram-se os testes na máquina de ensaios em ângulo de $130^{\circ} \mathrm{com}$ o longo eixo do dente, à velocidade de $2,5 \mathrm{~mm} / \mathrm{min}$. As maiores resistências à fratura foram obtidas nos grupos 5 e 6 , seguindo-se em ordem decrescente os grupos $4,3,1$ e 2. Os valores dos grupos 5 e 6 foram significativamente mais altos que os dos demais grupos, sugerindo que o fator crítico para a maior resistência foi manter pelo menos $1 \mathrm{~mm}$ de estrutura coronária, para obtenção de efeito férula a partir de paredes paralelas. Não houve aumento da resistência nos grupos com paredes radiculares mais espessas. Os diferentes desenhos de férulas também não aumentaram a resistência à fratura.

No ano de 1990, DURET; REYNAUD; DURET ${ }^{27}$ apud MANNOCCl et al. ${ }^{78}$, em 1998, baseados nas excelentes propriedades físicas da fibra de carbono, com larga aplicação na indústria automobilística, aeroespacial e esportiva, idealizaram um pino intra-radicular à base de fibras de carbono longas e em disposição paralela, imersas em matriz de resina epóxica. Este sistema, denominado em seu país de origem (França) como Composipost, baseia-se no conceito de monobloco entre núcleo 
e raiz, pois as propriedades biomecânicas do pino, especialmente o módulo de elasticidade (rigidez), são similares às da estrutura dentária, além de ser adesivamente unido ao esmalte e à dentina. Segundo os pesquisadores, o sistema representou uma inovação em desenho, composição e performance na área de pinos pré-fabricados, apresentando-se como um núcleo passivo em dois estágios e disponível em três tamanhos, com brocas estandardizadas para preparo dos condutos.

KING; SETCHELL ${ }^{69}$, em 1990, avaliaram a resistência à fratura de dentes anteriores (incisivos centrais superiores e caninos inferiores ou superiores) restaurados com quatro tipos de núcleos. Pinos de fibra de carbono experimentais tiveram a porção coronária fundida em ouro (grupo B) ou construída com resina composta (grupo C) e foram cimentados com cimento resinoso. Utilizaram-se dois grupos controle (cimentados com fosfato de zinco): um com pinos de liga preciosa (Para-Post) com porção coronária fundida em ouro (grupo A) e outro com pinos de aço (Para-Post) com porção coronária em resina composta (grupo D). Os espécimes receberam coroas metálicas fundidas e sofreram compressão em ângulo de $130^{\circ} \mathrm{com}$ o longo eixo da raiz. Dentes restaurados com pinos de fibras de carbono exibiram desempenho comparável (em alguns espécimes até melhor) ao dos pinos metálicos. $O$ modo de falha (nível de fratura) de dentes restaurados com pinos de fibras de carbono foi mais favorável para o remanescente dentário que o dos pinos metálicos.

SORNKUL; STANNARD ${ }^{125}$, em 1992, avaliaram a resistência à fratura dentária antes e após procedimentos endodônticos e restauradores. Empregaram 140 pré-molares inferiores, distribuídos em sete grupos. No grupo 1, os dentes não receberam tratamento endodôntico nem restaurador, mas somente preparo coronário. Nos demais grupos, as raízes foram endodonticamente tratadas, a porção interna das coroas foi alargada para obtenção de uma forma afunilada (abertura vestíbulo-lingual de $3 \mathrm{~mm}$ e mésio-distal de $2 \mathrm{~mm}$ ) e um preparo para coroa total com $5 \mathrm{~mm}$ de altura foi executado. No grupo 2 utilizou-se resina composta (sem sistema adesivo) para preenchimento coronário. No grupo 3 utilizou-se a mesma resina, mas com sistema adesivo. No grupo 4 preparou-se o conduto até $10 \mathrm{~mm}$ de profundidade com a broca $\mathrm{n}^{0}$ 4 do sistema Para-Post ( $1 \mathrm{~mm}$ de diâmetro) e cimentou-se o pino compatível deste sistema com resina composta associada ao sistema adesivo. O preparo nos grupo $5 \mathrm{e}$ 6 foi similar ao do grupo 4. No grupo 5 obteve-se um núcleo metálico fundido, que foi cimentado com fosfato de zinco. No grupo 6 , não se executou nenhum tratamento restaurador, para determinar a resistência do dente tratado endodonticamente e 
preparado para coroa total, mas não restaurado. No grupo 7 , confeccionaram-se "dentes" de resina composta autopolimerizável, usando como molde uma raiz preparada, para determinar a resistência de dentes totalmente reforçados internamente com resina composta. Na máquina de ensaios, aplicaram-se cargas compressivas (perpendiculares à superfície oclusal) e de cisalhamento (ângulo de $45^{\circ}$ com o longo eixo da raiz). Os grupos com maior resistência foram o grupo 1 (raízes inalteradas) e o grupo 3 (resina composta com sistema adesivo). Quando cimentados pinos pré-fabricados com resina composta (grupo 4), a resistência diminuiu; a resistência do grupo 7 foi similar à do grupo 4. Preenchimento com resina composta sem sistema adesivo (grupo 2) e núcleo metálico fundido (grupo 5) foram os próximos na magnitude. O grupo de menor resistência foi o dos dentes preparados sem qualquer restauração (grupo 6). Os autores concluíram que os fatores que auxiliaram a evitar fraturas foram: quantidade de remanescente dentário; resistência dos pinos e material de preenchimento coronário; e adesão entre dentina e material de preenchimento coronário. Sugeriram pesquisas para aumentar a adesão entre materiais restauradores e estrutura dentária, possibilitando seu reforço.

MILOT; STEIN ${ }^{83}$, em 1992, investigaram o papel do bisel na resistência à fratura de 48 dentes plásticos padronizados (simulando incisivos centrais), divididos em três grupos de 16 dentes. No grupo 1 cimentaram-se núcleos metálicos fundidos (diâmetro de $0,8 \mathrm{~mm}$ na porção apical e 2,8mm na porção cervical). No grupo 2 utilizaram-se pinos Para-Post Plus $n^{0} 5$ (1,15mm de diâmetro). No grupo 3 utilizaramse pinos Flexi-Post $n^{0} 1$ (1,1mm de diâmetro). Para construção da porção coronária do núcleo nos grupos 2 e 3 empregou-se ionômero de vidro reforçado com prata. Metade dos dentes de cada grupo permaneceu intacta (somente com chanfro) e metade recebeu um bisel côncavo (férula) com $1 \mathrm{~mm}$ de diâmetro. Sobre os núcleos, cimentaram-se coroas metálicas fundidas. Aplicaram-se forças compressivas por lingual à velocidade de $50 \mathrm{~mm} / \mathrm{min}$ e com inclinação de $120^{\circ}$ em relação ao longo eixo da raiz. Espécimes com férula exibiram maior resistência à fratura, e fraturas verticais ocorreram em quantidade duas vezes maior em preparos sem férula. $O$ tipo de pino teve pouco ou nenhum efeito sobre a resistência final.

TROPE; RAY ${ }^{133}$, em 1992, determinaram a resistência à fratura sob cargas compressivas de 48 caninos inferiores, distribuídos em quatro grupos (12 dentes cada): no grupo 1 , os condutos instrumentados endodonticamente foram obturados com cimento de ionômero de vidro (Ketac Endo); no grupo 2, os condutos 
não foram instrumentados; no grupo 3, os canais foram instrumentados, mas não obturados; no grupo 4, os canais instrumentados foram obturados com cimento endodôntico convencional (cimento de Roth). A instrumentação endodôntica enfraqueceu significativamente as raízes. A obturação com cimento convencional não reforçou as raízes, mas a obturação com cimento ionomérico reforçou significativamente as raízes quando comparadas com raízes instrumentadas e não obturadas ou obturadas com cimento convencional.

MILLER $^{82}$ analisou, em 1993, um material à base de fibras de polietileno entrelaçadas denominado Ribbond e comercializado em forma de fitas, originalmente indicado para esplintagem periodontal e retenção ortodôntica. Usos alternativos seriam: núcleos de preenchimento, próteses adesivas diretas ou indiretas, reforço de próteses provisórias, infra-estrutura de onlays, coroas e próteses parciais fixas de compósitos, reforço de dentes fraturados, reparo de cantilever fraturado de próteses implantossuportadas, reparo de próteses removíveis totais ou parciais e de aparelhos ortodônticos removíveis. As principais características físicas do material são: alto módulo de elasticidade, alta resistência à tração e baixa sorção de água (1\%). O autor afirmou que o Ribbond possui vantagens como: união química à resina composta ou acrílica; alta maleabilidade (quase sem memória elástica); cor branca, compatível com a das resinas; estrutura entrelaçada, que fornece reforço multidirecional da resina e não desfia. A adesão com resinas deve-se ao tratamento eletroquímico da superfície com gás plasma: uma camada externa de $200 \mathrm{~A}^{\circ}$ torna-se quimicamente reativa. As fitas são colocadas em uma câmara selada, que é preenchida por gás e exposta a altas cargas de energia elétrica. Para não contaminar a superfície, o material não deve ser tocado por dedos desprotegidos, lençol de borracha ou luvas de vinil. A flexibilidade da fita permite amortecimento (dissipação do estresse) das forças funcionais ou parafuncionais presentes na cavidade oral, aumentando a resistência à fratura.

ASSIF et al. ${ }^{6}$, em 1993, examinaram o efeito do desenho de pinos intraradiculares na resistência à fratura de 41 pré-molares endodonticamente tratados e restaurados com coroas metálicas fundidas, divididos em quatro grupos: grupo 1 núcleos metálicos fundidos cônicos; grupo 2 - pino cilíndrico Para-Post com porção coronária fundida; grupo 3 - pino cilíndrico Para-Post com extremidade cônica e porção coronária fundida; grupo 4 - raízes sem pinos, preenchidas com ionômero de vidro. Mantiveram-se $2 \mathrm{~mm}$ de estrutura dental sadia apicalmente ao término da porção 
coronária do núcleo (para efeito de férula) e aplicaram-se cargas compressivas em ângulo de $30^{\circ}$ com o longo eixo da raiz. O desenho dos núcleos não influenciou na resistência à fratura e não houve diferença significativa entre dentes com ou sem núcleos, quando o núcleo foi coberto com uma coroa total metálica com $2 \mathrm{~mm}$ de férula. Sugeriram que uma coroa total com férula de $2 \mathrm{~mm}$ distribuiria melhor o estresse para a raiz e núcleo, minimizando o risco de fraturas verticais, e que se a porção coronária está suficientemente preservada para fornecer retenção ao material restaurador, não é necessário utilizar pinos.

A influência de pinos na distribuição do estresse na dentina foi investigada por $\mathrm{HO}$ et al. ${ }^{55}$, em 1994, através do método do elemento finito. Utilizaramse modelos simulando incisivos centrais superiores endodonticamente tratados com ou sem pinos (fundidos em ouro ou pré-fabricados de aço inoxidável). Aplicaram-se dois tipos de carga: forças linguais simulando mastigação (ângulo de $45^{\circ}$ ) e forças traumáticas aplicadas horizontalmente na face vestibular da coroa, ambas com 100N. O uso de pinos não diminuiu significativamente o estresse (compressivo ou à tração) na dentina em relação à restauração sem pinos. Concluiu-se que o efeito de reforço de núcleos fundidos ou pinos pré-fabricados em dentes despolpados é duvidoso.

ROVATTI; MASON; DALLARI ${ }^{110}$, em 1994, investigaram a resistência à tração do pino Composipost com os cimentos resinosos Sealbond e Flexiflow, obtendo média de $73 \mathrm{~kg} / \mathrm{cm}^{2}$ para o primeiro e de $72 \mathrm{~kg} / \mathrm{cm}^{2}$ para o segundo. Relataram também que a força necessária para remover fibras de carbono da matriz de resina epóxica é de $75-78 \mathrm{~kg} / \mathrm{cm}^{2}$. Como o pino é liso (sem retenções mecânicas superficiais), toda a retenção é dada pela adesão; isto foi confirmado pela cimentação de dois pinos em pré-molares com duas raízes, pois a força de tração necessária para removê-los manteve-se na média de $73 \mathrm{~kg} / \mathrm{cm}^{2}$. Testaram ainda um protótipo denominado Composipost Retentivo (com sulcos a intervalos regulares) com cinco cimentos: Sticky Post, Flexi Flow, Sealbond, Super Bond e All Bond II. Os resultados dos testes de resistência à tração foram, respectivamente $\left(\mathrm{em} \mathrm{kg} / \mathrm{cm}^{2}\right)$ : 88, 88, 92, 120 e 127. Os valores obtidos com Super Bond e com All Bond II foram os melhores já obtidos com pinos passivos. Considerou-se excelente a idéia de um pino passivo com elasticidade similar à da dentina e adesivamente unido às paredes do conduto, bem como promissor o conceito de restauração em monobloco (união entre materiais heterogêneos através da adesão). 
Em 1994, LUI ${ }^{75}$ descreveu uma técnica para reforçar raízes com condutos excessivamente alargados através de seu preenchimento com resina composta fotopolimerizável. Para melhor polimerização da resina nas porções mais profundas do conduto, indicou o pino plástico fototransmissor Luminex, que permite obtenção de um conduto preciso ao qual se adaptam outros pinos (componentes do sistema Luminex) de tamanho e forma idênticos, que podem ser de aço inoxidável, titânio, ouro ou mesmo calcináveis (para fundição do pino). A técnica permite aproveitamento de raízes que de outra forma seriam indicadas para extração.

Em 1995, HORNBROOK; HASTINGS ${ }^{57}$ apresentaram um método de confecção de pinos com fibras de polietileno Ribbond. Afirmaram que em condutos alargados os núcleos metálicos fundidos são contra-indicados, devido ao efeito de cunha. Pinos pré-fabricados também não são ideais, pois sua adaptação é imperfeita e a espessa camada de cimento em torno do pino gera um prognóstico desfavorável. Além disso, o resultado será antiestético se executadas coroas de cerâmica pura. $O$ pino de fibras de polietileno é adesivo, anti-rotacional e passivo, sendo indicado inclusive para canais alargados. Forma uma unidade com a raiz pela união de materiais adesivos entre si, reforçando-a e reduzindo o risco de fratura. Também impediria propagação de trincas já existentes nas paredes até o periodonto e não compromete a estética. Para sua confecção, remove-se guta-percha até permitir a obtenção de um pino com comprimento igual à altura da porção coronária do núcleo. $\mathrm{A}$ largura de fita mais usada para pinos é $2 \mathrm{~mm}$; a de $3 \mathrm{~mm}$ pode ser usada em canais largos e a de $4 \mathrm{~mm}$ em câmaras pulpares de molares inferiores. O comprimento da fita deve ser cerca de três vezes o do conduto, medido com sonda periodontal. A fibra é impregnada com adesivo fotopolimerizável sem carga. O remanescente dentário sofre condicionamento ácido e o sistema adesivo é aplicado. Cimento resinoso dual, híbrido e com carga é injetado no conduto com a ponta agulha da seringa Centrix. A fita dobrada é levada ao conduto com condensador endodôntico, preenchendo-o totalmente. Em condutos largos insere-se uma segunda fita com 1,5 vezes o comprimento do canal. O conjunto é fotopolimerizado e uma resina híbrida é aplicada em torno das fibras que emergem do conduto para construir a porção coronária do núcleo. Os autores utilizaram a técnica em 24 casos durante 12 meses, sem nenhuma falha clínica, mesmo em dentes severamente comprometidos.

Em 1995, LIBMAN; NICHOLLS ${ }^{73}$ avaliaram a influência da altura da férula sobre a resistência à fratura de incisivos centrais superiores restaurados com 
núcleos metálicos fundidos. Espécimes de quatro grupos receberam coroas totais com altura de férula variando de 0,5 a 2,0 $\mathrm{mm}$, em incrementos de $0,5 \mathrm{~mm}$; um quinto grupo (controle) não recebeu núcleos. Aplicaram-se cargas cíclicas (72 ciclos por minuto) em ângulo de $135^{\circ}$ com o longo eixo do dente. O número de ciclos necessários para causar falha preliminar por fadiga (perda de selamento entre coroa e dente por fratura do cimento) foi significativamente menor com férulas de $0,5 \mathrm{~mm}$ e $1,0 \mathrm{~mm}$ do que com férulas de $1,5 \mathrm{~mm}$ e $2,0 \mathrm{~mm}$ e do que no grupo controle.

Em 1996, DURET; DURET; REYNAUD ${ }^{26}$ descreveram o efeito do módulo de elasticidade na transmissão da força para a dentina que envolve o pino. Cimentaram-se três pinos de formas idênticas em incisivos centrais superiores: um de níquel-cromo (módulo de elasticidade de 210GPa), um de titânio (módulo de elasticidade de 110GPa) e o pino de fibras de carbono C-Post (módulo de elasticidade de $8 \mathrm{GPa}$ ). Aplicou-se uma carga de $1 \mathrm{~N}$ na borda incisal do dente, em $90^{\circ}$ com o longo eixo do dente e do pino. Quanto mais alto o módulo de elasticidade do pino, mais força foi transmitida para a dentina; assim, o pino ideal deveria possuir módulo de elasticidade próximo ao da dentina. Realizaram ainda testes de resistência à fadiga na máquina de ensaios, comparando dois pinos de fibras de carbono (C-Post e EndoComposipost) com três pinos metálicos de diâmetro similar ao C-Post: Para-Post, Flexi-Post e Adpost. Observou-se que pinos de fibra de carbono resistiram melhor à fadiga que os metálicos, os quais deformaram progressivamente. Somente dois CPost fraturaram no teste de fadiga; já os pinos metálicos com freqüência fraturavam antes do fim da série de ciclos. Observaram queda de menos de $20 \%$ na resistência do C-Post ao final do teste, mas os pinos metálicos não possuíam praticamente mais nenhuma resistência. A elasticidade não foi afetada no C-Post, mas diminuiu muito nos pinos metálicos. Concluíram que com pinos de fibras de carbono o risco de fratura da raiz diminui, pois as deformações ocorridas com pinos metálicos levam a trincas da dentina. As fibras de carbono são unidas por uma matriz de resina epóxica; são longas, orientadas unidirecionalmente no longo eixo do pino e eqüitativamente distribuídas no mesmo. O pino tem forma cilíndrica e dois estágios, um cervical de maior diâmetro e um apical de menor diâmetro. O ápice é cônico para maior estabilização. Seu módulo de elasticidade varia de 8GPa a 110GPa. Com ângulo de incidência de $90^{\circ} \mathrm{com}$ o longo eixo do pino, o módulo é de $8 \mathrm{GPa}$ (próximo ao da dentina radicular); com ângulo de incidência de 20 a $45^{\circ}$ com o longo eixo, o módulo é de 18 a 30GPa; com ângulo de incidência de $0^{\circ}$, o módulo é de 100 a $110 \mathrm{GPa}$. A resina epóxica tem excelente adesão a resinas compostas e cimentos resinosos. 
SAUPE; GLUSKIN; RADKE ${ }^{114}$, em 1996, investigaram a possibilidade de reforçar internamente com resina composta as paredes radiculares destruídas. Após remoção das coroas ( 1 a $2 \mathrm{~mm}$ acima da junção cemento-esmalte), distribuíramse 40 incisivos centrais superiores tratados endodonticamente em quatro grupos: 1) raiz sem reforço e núcleo metálico fundido em ouro tipo III (sem férula); 2) raiz sem reforço e núcleo metálico fundido (com férula); 3) raiz com reforço e núcleo metálico fundido (sem férula); 4) raiz com reforço e núcleo metálico fundido (com férula). Desgastou-se a estrutura interna das raízes até $8 \mathrm{~mm}$ de profundidade, mantendo-se a espessura de paredes radiculares de 0,5 a $0,75 \mathrm{~mm}$. Para auxiliar a polimerizar a resina composta, utilizou-se o pino transiluminador Luminex. Cimentararam-se os núcleos com cimento resinoso Enforce. Aplicaram-se cargas compressivas na face lingual dos núcleos à velocidade de $2 \mathrm{~mm} / \mathrm{min}$. Grupos reforçados foram $50 \%$ mais resistentes à fratura que grupos sem reforço. Nos grupos reforçados não houve diferença significativa entre núcleos com ou sem férula, possivelmente graças a um "abraçamento" ou "amarramento" interno conferido pelas propriedades adesivas do sistema, que substitui a férula extracoronária.

PURTON; LOVE ${ }^{102}$, em 1996, avaliaram rigidez e retenção de pinos de fibras de carbono lisos (Endopost) em relação aos pinos de aço inoxidável serrilhados (Para-Post), ambos com $1 \mathrm{~mm}$ de diâmetro. Cimentaram-se os pinos com cimento resinoso em condutos estreitos (cerca de $1 \mathrm{~mm}$ de diâmetro) e endodonticamente tratados de incisivos e pré-molares unirradiculares. Os pinos Para-Post demonstraram significativamente mais retenção e maior rigidez. A maior retenção do Para-Post provavelmente foi devido à sua superfície serrilhada, enquanto o Endopost possui superfície lisa. Os autores concluíram que o pino Para-Post parece mecanicamente mais recomendável que o Endopost para restaurar dentes com condutos estreitos.

ISIDOR; ODMAN; BRONDUM ${ }^{60}$, em 1996, avaliaram a resistência à fratura de 40 dentes bovinos restaurados com pinos de fibras de carbono Composipost. Simulou-se o ligamento periodontal com silicona em torno das raízes, que foram fixadas em blocos de resina acrílica. Preparou-se o conduto até $8,5 \mathrm{~mm}$ de profundidade. Cimentaram-se os pinos com cimento resinoso e restaurou-se a porção coronária com resina composta. Cimentaram-se coroas metálicas com fosfato de zinco e submeteram-se os espécimes à carga intermitente (250N, 2 cargas por segundo) em ângulo de $45^{\circ} \mathrm{com}$ o longo eixo do dente. Os resultados foram comparados a estudo prévio dos autores, conduzido sob condições similares, porém usando pinos metálicos 
paralelos Para-Post e núcleos metálicos fundidos cônicos em prata-paládio. Enquanto nenhum dos pinos de fibras de carbono falhou no segundo estudo (não houve perda ou fratura da coroa e nem do pino) até o número de ciclos proposto, todos os núcleos metálicos fundidos e quase todos os pinos Para-Post do estudo prévio falharam (diferença estatisticamente significativa). Somente quatro dos 14 espécimes com Composipost mostraram fratura longitudinal incompleta. A maior resistência com este pino foi atribuída ao módulo de elasticidade próximo ao da dentina (melhor distribuição do estresse ao longo do pino), à sua forma (paredes paralelas) e ao preparo conservador do conduto em áreas apicais críticas.

Em 1996, PURTON; PAYNE ${ }^{103}$ compararam a rigidez entre pinos lisos de fibras de carbono Composipost e pinos serrilhados de aço inoxidável Para-Post de diâmetros similares. Para obter o módulo de elasticidade dos pinos, um teste de flexão dos três pontos foi feito na máquina de ensaios. Também foi comparada a retenção da resina composta Ti-Core à porção coronária destes pinos, submetendo a resina a forças de tração. Executaram-se ambos os testes à velocidade de $10 \mathrm{~mm} / \mathrm{min}$. Os autores consideraram adequada a rigidez dos pinos Composipost, cujo módulo de elasticidade foi significativamente maior que o dos pinos Para-Post. A retenção da resina composta foi significativamente maior nos pinos de aço que nos pinos de fibras de carbono, provavelmente devido à presença de serrilhado no pino de aço.

Segundo FREEDMAN ${ }^{40}$, em 1996, os componentes do pino de fibra de carbono são fibras, matriz e interface. As fibras de carbono têm $8 \mu \mathrm{m}$ de diâmetro, são contínuas e longitudinalmente dispostas nos pinos. Representam $64 \%$ do peso total, conferindo alta resistência ao pino. A arquitetura interna absorve os esforços aplicados à prótese, redirecionando-os para o longo eixo da raiz. A matriz ( $36 \%$ do peso total) é uma resina epóxica que envolve as fibras. A interface é composta por agentes de adesão na área de união da fibra com a matriz. Quando o estresse transmitido pelos pinos à estrutura dentária foi comparado entre pinos de níquel-cromo, titânio e de fibras de carbono, o último transmitiu cerca de $65 \%$ de esforços em relação ao Ti e um terço em relação ao níquel-cromo. Pinos metálicos, por possuírem módulo de elasticidade até dez vezes maior que o da dentina, geram alto estresse na interface dente-cimento-pino, podendo causar deslocamento do pino ou fratura da raiz. $O$ módulo de elasticidade do pino de fibras de carbono é similar ao da dentina. As propriedades adesivas do pino aumentam a resistência dentária e diminuem a microinfiltração. A forma do pino - um cilindro formado por dois cones - respeita a forma do 
canal, e cada cone gera uma parada para estabilização vertical e distribuição do estresse. Após mais de um bilhão de cargas consecutivas em pinos de fibras de carbono não houve fratura de nenhum pino, e apenas $30 \%$ das raízes sofreram fratura longitudinal. Quanto a estudos clínicos, 89 profissionais trataram mais de 1100 pacientes com esses pinos, que após três anos estavam todos intactos. Ocorreu uma pequena porcentagem de falhas $(2 \%)$, atribuídas à falta de manutenção periodontal e lesões periapicais.

Em 1996, KARNA ${ }^{65}$ publicou os resultados de um estudo piloto que foi a primeira tentativa de determinar as propriedades físicas dos núcleos de fibras de polietileno Ribbond. Para sua confecção, removem-se 6 a $7 \mathrm{~mm}$ de guta-percha, condiciona-se o conduto e aplica-se o sistema adesivo. Geralmente utiliza-se a fita de $2 \mathrm{~mm}$ de largura. Para determinar o comprimento da fita, mede-se o conduto com sonda periodontal, multiplica-se o valor obtido por 2 e adiciona-se mais 16 a $20 \mathrm{~mm}$. Depois de impregnada com adesivo, a fita é dobrada na forma da letra "V", cuja parte interna é coberta com cimento resinoso dual injetado com a ponta agulha da seringa Centrix, também utilizada para levar cimento ao conduto. Para condensar a fita no conduto, utiliza-se o instrumento desenhado pelo fabricante ou um condensador endodôntico modificado. Se possível, insere-se uma segunda fita para melhor preenchimento do conduto. Coloca-se mais cimento entre as fitas que emergem do conduto, modela-se o pino e fotopolimeriza-se. Após condicionamento ácido do pino, aplica-se sistema adesivo e resina composta para confecção da porção coronária do núcleo. Confeccionaram-se cinco espécimes com pinos de fibras de polietileno, nas seguintes situações: um $1^{0}$ pré-molar inferior, um incisivo lateral superior e um incisivo central inferior, todos sem coroa; um $1^{0}$ pré-molar superior sem a cúspide lingual; um $3^{0}$ molar superior com preparo para coroa total. Fixaram-se os dentes em blocos de resina acrílica, $2 \mathrm{~mm}$ acima da junção cemento-esmalte e utilizaram-se duas fitas em cada núcleo. Submeteram-se os espécimes à carga na máquina de ensaios em ângulo de $40^{\circ}$ com o longo eixo (simulando cisalhamento). As forças necessárias para fraturar os espécimes geralmente foram superiores àquelas geradas intra-oralmente (resultados na Tabela 2.1). Na fase clínica dos testes, reconstruíram-se mais de 130 dentes com núcleos de Ribbond, observando-se apenas dois casos de fratura de raiz, que possuíam paredes radiculares com menos de $1 \mathrm{~mm}$ de espessura e três casos de fratura da resina composta coronária. O tipo de falha mais comum destes núcleos parece ser a fratura unicamente da resina composta coronária; porém, pode-se reconstruir o núcleo e recimentar a coroa. As vantagens de tais núcleos são: (1) 
Conservação da estrutura dentária - o canal não precisa ser alargado, como em núcleos metálicos fundidos; (2) Morfológica - o completo preenchimento do conduto, aliado à adesão do pino às suas irregularidades, torna-o retentivo e não-rotacional; (3) Compatível com a flexibilidade da raiz - a flexibilidade das fibras e a adesividade minimizam a propagação de micro-fraturas da raiz; (4) Memória elástica mínima das fibras - facilita a inserção no canal; (5) Estética - cor similar à do dente e ausência de corrosão; (6) Rápida remoção, com risco mínimo à estrutura dentária; (7) Custo similar ao de pinos pré-fabricados.

TABELA 2.1 - Valores de resistência à fratura e padrões de falha para dentes tratados endodonticamente e restaurados com núcleos de fibras de polietileno (KARNA, 1996)

\begin{tabular}{l|l|l|l} 
Dentes / Situação de destruição & $\begin{array}{l}\text { Limiar de } \\
\text { falha (kgf) }\end{array}$ & $\begin{array}{l}\text { Fratura da } \\
\text { raiz }\end{array}$ & $\begin{array}{l}\text { Fratura ou } \\
\text { dano da porção } \\
\text { coronária }\end{array}$ \\
\hline $\begin{array}{l}\text { Incisivo superior com coroa } \\
\text { removida }\end{array}$ & 45 & Não & Não \\
\hline $\begin{array}{l}\text { Incisivo inferior com coroa removida } \\
\begin{array}{l}\text { Pré-molar inferior com coroa } \\
\text { removida }\end{array}\end{array}$ & 44 & Sim & Sim \\
\hline $\begin{array}{l}\text { Pré-molar superior sem cúspide } \\
\text { lingual }\end{array}$ & 122 & Não & Fragmentação \\
\hline $\begin{array}{l}3^{0} \text { molar superior preparado para } \\
\text { coroa total }\end{array}$ & 390 & Não & $\begin{array}{l}\text { Fragmentação } \\
\text { da resina }\end{array}$ \\
\hline
\end{tabular}

No ano de 1997, MARCHI ${ }^{80}$ avaliou a resistência à fratura de raízes debilitadas reconstruídas internamente com resina composta e pinos intra-radiculares. Empregou 76 raízes de incisivos centrais superiores ou caninos superiores. Em metade das raízes foi executado desgaste interno de dimensões padronizadas, simulando enfraquecimento; as raízes foram preenchidas com resina composta fotopolimerizável. As outras 38 raízes eram hígidas. Ambos os grupos foram subdivididos igualmente para receber pinos metálicos Radix-Anker (1,35mm de diâmetro) ou núcleos metálicos fundidos. Aplicou-se uma carga de compressão sobre os espécimes na máquina de ensaios, em ângulo de $135^{\circ}$ com o longo eixo da raiz e à velocidade de $0,5 \mathrm{~mm} / \mathrm{min}$. Os fatores analisados foram: 1) volume da raiz (pequena, 
média ou grande) - as maiores apresentaram maior resistência à fratura; 2) condição da raiz (hígida ou debilitada) - as hígidas mostraram-se mais resistentes; 3) tipo de pino intra-radicular (núcleo metálico fundido ou pino metálico pré-fabricado) - os pinos pré-fabricados tiveram melhor performance. A interação que apresentou a maior resistência foi: raízes grandes, hígidas e com pinos pré-fabricados. O autor concluiu que: a espessura de dentina remanescente em torno do núcleo está diretamente relacionada à resistência da raiz à fratura; pinos paralelos e rosqueados proporcionam maior resistência que núcleos metálicos fundidos cônicos; e que a resina composta não recuperou toda a resistência original do dente à fratura.

O estudo de DIETSCHI; ROMELLI; GORETTI ${ }^{24}$, em 1997, investigou a adaptação de pinos cimentados com cimento resinoso à dentina após teste de resistência à fadiga. Avaliaram um pino de zircônia, dois pinos de titânio e dois pinos de fibras de carbono. Os espécimes foram submetidos a cargas cíclicas e termociclagem. Observaram-se secções dos espécimes em microscópio eletrônico de varredura para verificar deficiências na interface entre materiais restauradores e dentina. O pino de titânio exibiu a maior solução de continuidade ao nível de dentina coronária $(83,88 \%)$ ou radicular $(78,12 \%)$; também o pino de zircônia mostrou insuficiente adaptação à dentina coronária $(53,25 \%$ de continuidade) ou radicular $(21,25 \%$ de continuidade), demonstrando baixa adesão à resina. O pino de fibra de carbono comportou-se melhor $(67,38 \%$ de continuidade ao nível radicular e $44,88 \%$ ao nível coronário) que o pino de titânio.

Em 1997, BURGESS; DOUGLAS; NORLING ${ }^{17}$ mediram a resistência à compressão, flexão e tração de dois pinos metálicos pré-fabricados (Para-Post e ParaPost XP) e dois pinos de fibras de carbono (C-Post liso e C-Post serrilhado), divididos em 12 grupos (10 dentes cada). Pré-molares unirradiculares foram seccionados ao nível da junção cemento-esmalte e tratados endodonticamente. Preparou-se o conduto com as brocas fornecidas pelos fabricantes até a profundidade de $8 \mathrm{~mm}$. O C-Post foi jateado com óxido de alumínio. Os pinos foram cimentados com cimento resinoso Panavia 21 e os espécimes foram submetidos à carga até a falha do sistema. As resistências à flexão, tração e compressão de ambos os pinos de fibra de carbono foram significativamente menores que aquelas dos pinos metálicos.

No DENTAL PRODUCTS REPORT ${ }^{30}$, em 1997, descreveu-se um caso clínico de confecção de núcleo com fibras cerâmicas GlasSpan. Um núcleo 
confeccionado com fibras minimizaria o potencial para fraturas da raiz, além de aumentar a resistência à flexão e tração de resinas compostas. No kit do produto, há quatro configurações de fitas; a mais larga tem forma de um cordão oco e é a mais indicada para núcleos intra-radiculares. Uma paciente necessitava de coroa total no dente 13. Após remoção de dois terços da obturação radicular, o conduto e o remanescente coronário foram condicionados com ácido fosfórico, sendo após aplicado o sistema adesivo. Uma gota de adesivo foi colocada no extremo do cordão e fotopolimerizada, enrijecendo esta ponta para evitar escape de cimento. No outro extremo, a fita foi desfiada para permitir inserção de uma ponta agulha de seringa Centrix em seu interior. Recobriu-se toda a fita com adesivo, não polimerizado neste momento. O cimento resinoso autopolimerizável fluido foi inserido na ponta Centrix, que foi usada para levar a fita até o conduto. Injetou-se o cimento enquanto a fita era inserida no canal. A força de extrusão do cimento através da agulha impele sua passagem através das fibras, cobrindo as paredes do conduto. A fita permaneceu no conduto e a agulha foi removida. As fibras que extruíam do conduto foram cobertas com resina composta para confecção da porção coronária do núcleo.

SIDOLI; KING; SETCHELL ${ }^{116}$, em 1997, compararam resistência à fratura e padrão de fratura de pinos de fibra de carbono com outros sistemas de núcleos. Distribuíram 40 incisivos centrais ou caninos superiores em quatro grupos de dez dentes. Aplicou-se carga estática compressiva de $2500 \mathrm{~N}$ sobre os espécimes em um ângulo de $130^{\circ}$ com o longo eixo do dente. Os grupos pesquisados foram: (1) pino de fibras de carbono Composipost e porção coronária de resina composta; (2) pino de aço inoxidável Para-Post e porção coronária de resina composta; (3) núcleos metálicos fundidos em ouro tipo III; e (4) dentes tratados endodonticamente sem núcleo. Cimentaram-se todos os pinos com cimento resinoso. O grupo no qual não foram utilizados núcleos foi significativamente mais resistente que os demais, sugerindo que o preparo do conduto enfraquece a raiz. Dentes restaurados com Composipost exibiram resistência inferior em relação aos demais sistemas, especialmente quando comparados com núcleos metálicos fundidos. Os autores conjeturaram que isto provavelmente ocorreu porque o pino de fibras de carbono não possui retenções mecânicas para a resina coronária. Considerou-se que o potencial para flexão do Composipost poderia levar à perda do cimento e micro-infiltração. A situação seria de maior risco se estes dentes fossem pilares de próteses parciais fixas ou removíveis. Contudo, o Composipost apresentou os melhores resultados em relação ao modo de fratura $(60 \%$ de fraturas favoráveis à preservação do 
remanescente dentário, ou seja, fratura somente do pino ou do dente acima do nível de inserção). Já com núcleos metálicos fundidos houve $100 \%$ de fraturas desfavoráveis, devido a seu alto módulo de elasticidade, que the proporciona baixa flexibilidade e o torna impróprio para absorver estresse. $O$ modo de fratura deve ser levado em consideração na seleção do núcleo.

A influência de diferentes procedimentos endodônticos e restauradores na resistência à fratura dentária foi avaliada por DEAN; JEANSONNE; SARKAR ${ }^{23}$, em 1998. No grupo 1 executou-se somente preparo coronário (sem tratamento endodôntico); no grupo 2 executou-se tratamento endodôntico e preparo coronário; o grupo 3 foi preparado como o grupo 2 e restaurou-se a câmara pulpar com resina composta; o grupo 4 foi preparado como acima e cimentou-se um pino de fibras de carbono no conduto. Nos grupos 5, 6 e 7 executaram-se tratamento endodôntico, remoção das coroas, cimentação de pinos de fibras de carbono, pinos de aço inoxidável cônicos e pinos de aço inoxidável paralelos, respectivamente, e construção da porção coronária em resina composta. Os espécimes foram submetidos à carga compressiva em ângulo de $45^{\circ} \mathrm{com}$ seu longo eixo, à velocidade de $0,5 \mathrm{~mm} / \mathrm{min}$. Grupos com pinos e porção coronária do núcleo em resina falharam com carga significativamente mais baixa que aqueles nos quais não se removeu a coroa. Não houve diferença significativa na resistência entre dentes restaurados com diferentes pinos. Dentes restaurados com pinos de fibras de carbono não sofreram nenhuma fratura de raiz, enquanto fraturas radiculares ocorreram em $50 \%$ dos dentes de cada um dos outros grupos onde foram usados pinos.

De acordo com MONDELLI ${ }^{85}$, em 1998, o desenvolvimento dos pinos de dióxido de zircônia Cerapost ocorreu em 1993. O pino é composto de 94,9\% de dióxido de zircônia e $5,1 \%$ de óxido de ítrio. Sua resistência $\left(1400 \mathrm{~N} / \mathrm{mm}^{2}\right)$ é maior que a das cerâmicas aluminizadas $\left(320-500 \mathrm{~N} / \mathrm{mm}^{2}\right)$ e que a do aço comum $\left(450 \mathrm{~N} / \mathrm{mm}^{2}\right)$, e próxima à do aço carbide $\left(1600 \mathrm{~N} / \mathrm{mm}^{2}\right)$. Apresentam-se com $25 \mathrm{~mm}$ de comprimento e em 3 diâmetros (ISO 50, 90 e 110), na cor branco-opaca (estética ideal para dentes anteriores). Pode ser utilizado com técnicas diretas ou indiretas. Na técnica direta é cimentado no conduto e revestido com materiais restauradores adesivos; na indireta a porção coronária é fundida com porcelanas reforçadas.

ROVATTI; MASON; DALLARI ${ }^{109}$, em 1998, relataram o desenvolvimento de pinos à base de fibras mais estéticos que os de carbono originais: 
o Aestheti-Post, com fibras de carbono recobertas por fibras de quartzo e o AesthetiPlus, totalmente composto de fibras de quartzo em matriz resinosa. A resistência à flexão destes pinos (1200-1500MPa), embora inferior à do Composipost (1900MPa), é suficiente para os requisitos clínicos. A resistência à tração lateral é levemente menor para pinos estéticos (50-60MPa) que para o Composipost (65-95MPa), mas isto facilita a remoção dos pinos se necessário, pois as brocas penetram facilmente entre as fibras. A resistência à tração longitudinal para estes pinos é de $2480 \mathrm{MPa}$. No teste de resistência à fadiga, estes pinos ultrapassaram cinco milhões de ciclos sem fratura. $A$ carga necessária para fratura é clinicamente suficiente para o Aestheti-Plus $\left(92,65 \mathrm{kgf} / \mathrm{mm}^{2}\right)$ e para o Aestheti-Post $\left(98,57 \mathrm{kgf} / \mathrm{mm}^{2}\right)$. Testes com o Aestheti-Plus revelaram excelente resistência à descimentação $(29,83 \mathrm{MPa})$, maior que a do Composipost $(27,12 \mathrm{MPa})$, mostrando adequada adesão das fibras de quartzo ao cimento resinoso. Os módulos de elasticidade do Aestheti-Post (55GPa) e do AesthetiPlus (44GPa) são mais favoráveis para dissipação do estresse que o de qualquer pino metálico.

KAKEHASHI et al. ${ }^{64}$, em 1998, analisaram o pino cerâmico Cosmopost, que é composto por policristais tetragonais de zircônia e possui alta resistência à flexão (1400MPa). No início, as porções coronárias dos núcleos eram cimentadas ao pino de zircônia, mas em 1997 foi introduzida a cerâmica IPS Empress Cosmo Ingots, fundida diretamente sobre o pino. Para dentes unitários, geralmente utiliza-se reconstrução direta: é feito um padrão de resina acrílica sobre o pino e o técnico prensa a cerâmica diretamente sobre o pino, sem confecção de modelo de trabalho. $O$ método indireto é utilizado para reconstruções simultâneas de mais de um dente; os pinos de zircônia são inseridos nos condutos, que são moldados para confecção de modelo de trabalho. O tamanho do núcleo após a prensagem é levemente maior que o padrão de resina original, sendo então condicionado com ácido hidrofluorídrico a $2 \%$ por sete minutos para melhorar a adaptação. Os autores cimentaram 24 pinos Cosmopost com porção coronária de cerâmica fundida em 12 incisivos, 2 caninos e 10 pré-molares, acompanhando-os por uma média de 15 meses. Sobre os núcleos cimentaram coroas de porcelana pura IPS Empress. Nenhuma falha foi observada. Investigaram ainda a influência do condicionamento da superfície do pino por jateamento com óxido de alumínio e o efeito da termociclagem na retenção da cerâmica fundida sobre os pinos, comparando-os com espécimes em que a porção coronária do núcleo foi cimentada com cimento resinoso. Prepararam-se quatro grupos experimentais. Antes da fundição da porção coronária, os pinos de dois dos 


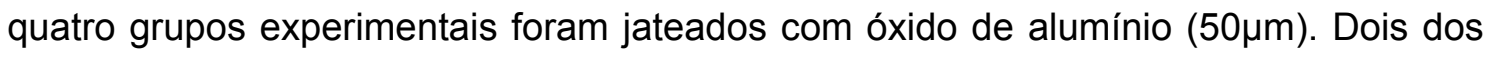
quatro grupos experimentais foram sujeitos à termociclagem $\left(5 / 55^{\circ} \mathrm{C}\right)$ por 330 horas. Após armazenamento em água a $37^{\circ} \mathrm{C}$, os pinos sofreram compressão à velocidade de $5 \mathrm{~mm} / \mathrm{min}$. Para pinos com superfícies não-tratadas, a cerâmica fundida apresentou retenção significativamente maior em relação à cimentação. Com pinos jateados, não houve diferença na retenção entre as duas técnicas. Após termociclagem, as superfícies de pinos jateados mostraram retenção significativamente maior que a de pinos não jateados. Concluiu-se que a fundição da porção coronária é tão eficaz na retenção da porção coronária quanto a cimentação.

Em 1998, MANNOCCl et al. ${ }^{79}$ investigaram os padrões de falhas e taxas de sucesso de núcleos metálicos fundidos e pinos de fibras de carbono. Três anos após o tratamento, analisaram-se 226 dentes com pinos de fibras de carbono e 194 dentes com núcleos metálicos fundidos, todos restaurados com coroas totais metalo-cerâmicas. Com pinos de fibras de carbono houve somente um caso de descimentação, sendo recimentados o pino e a coroa; não houve nenhuma fratura de raiz ou do pino. Já com núcleos metálicos fundidos houve dez fraturas de raiz. Houve diferença significativa entre os grupos, concluindo-se que a utilização de pinos de fibras de carbono e porção coronária do núcleo em resina composta praticamente eliminou o risco de fratura vertical de raiz.

MARTINEZ-INSUA et al. $^{81}$, em 1998, compararam a resistência à fratura entre dentes restaurados com pinos de fibras de carbono ou núcleos metálicos fundidos. Utilizaram-se 44 pré-molares, igualmente distribuídos para o grupo I, restaurado com pinos de fibras de carbono e porção coronária em resina composta e para o grupo II, restaurado com núcleos metálicos fundidos (ouro tipo III). Dimensão e forma dos pinos eram idênticos em ambos os grupos. Os dentes receberam coroas metálicas fundidas. Aplicou-se uma carga estática compressiva em ângulo de $45^{\circ} \mathrm{em}$ relação ao longo eixo do dente. A resistência do grupo II foi quase o dobro que a do grupo I (estatisticamente significativa). No grupo II, porém, houve fratura radicular em $91 \%$ dos espécimes (geralmente no terço cervical), enquanto no grupo I houve somente $5 \%$ de fraturas radiculares (todas no terço cervical). Os autores salientaram que cargas consideravelmente altas foram necessárias para gerar fraturas no grupo I (pinos de fibras de carbono) e que as cargas que provocaram fraturas dentárias no grupo II (núcleos metálicos fundidos) raramente ocorrem clinicamente. 
FREDRIKSSON et al. ${ }^{39}$, em 1998, analisaram as condições periodontais e os resultados protéticos em 130 dentes superiores e 106 dentes inferiores restaurados com pinos de fibras de carbono Composipost, após um período médio de 32 meses (27 a 41 meses). Cinco dentes (2\%) foram extraídos por razões nãorelacionadas com os pinos (geralmente doença periodontal severa). As condições periodontais (índice de placa, sangramento à sondagem e profundidade de bolsa) nos dentes com Composipost foram similares aos dentes controle (contra-laterais ou similares em anatomia e posição). Não houve deslocamento de pinos ou de restaurações, nem fratura de raízes ou pinos. O exame radiográfico não revelou casos de reabsorção pronunciada da crista óssea. Os resultados promissores indicaram que pinos de fibras de carbono, que oferecem resiliência compatível com a do remanescente dentário e adesão ao mesmo, podem ser uma alternativa viável aos núcleos metálicos fundidos, que possuem padrão de sucesso inferior.

Segundo MONTENEGRO ${ }^{86}$, em 1998, a utilização de núcleos pela técnica direta vem aumentando, por sua praticidade e rapidez. Uma nova tendência vem se delineando: a de pinos não-metálicos, que associam um elemento de alta resistência (fibras de carbono, polietileno ou cerâmicas) com resinas compostas. As fibras em forma de fita podem ser usadas para confecção de núcleos diretos e sua principal indicação está em raízes com canal amplo ou comprometido por cárie, com paredes enfraquecidas. A resina composta preferencialmente indicada para cimentação e preenchimento coronário deve ser autopolimerizável ou de presa dual e radiopaca.

KATEBZADEH; DALTON; TROPE ${ }^{66}$, em 1998, avaliaram a capacidade da resina composta de reforçar internamente dentes com maturação incompleta. Afirmaram que o trauma de um dente jovem pode impedir o desenvolvimento completo do ápice e paredes radiculares. As paredes radiculares finas na região cervical tornam estes dentes susceptíveis a fraturas $(30 \%$ fraturam durante ou após tratamento endodôntico). Distribuíram-se 100 incisivos centrais endodonticamente tratados em cinco grupos (20 dentes cada). No grupo 1 (controle), não executou-se nenhum preparo cervical e restaurou-se a câmara pulpar com resina composta fotopolimerizável. Preparam-se os condutos nos grupos 2 a 5 simulando paredes radiculares finas na região cervical, até $3 \mathrm{~mm}$ apicalmente à junção cemento-esmalte (JCE). No grupo 2 (controle negativo), restaurou-se a câmara pulpar com resina composta somente até o nível da JCE. No grupo 3, restaurou-se a câmara pulpar com 
resina composta até $3 \mathrm{~mm}$ apicalmente à JCE, introduzindo-se o pino plástico fototransmissor Luminex na resina antes da polimerização, executada por 60 segundos. Após remoção do Luminex, obtinha-se um canal de resina desobstruído. No grupo 4, restaurou-se a câmara como no grupo 3, substituindo o pino translúcido por um pino opaco e polimerizando-se o compósito por 60 segundos. O pino foi então removido, deixando um conduto de resina. O grupo 5 foi tratado como o grupo 3, mas após remoção do pino translúcido, cimentou-se um pino metálico Luminex no canal com cimento resinoso. Para cada grupo, registrou-se a força de compressão necessária para causar fratura cervical. Todas as técnicas utilizando resina composta reforçaram significativamente os dentes contra fratura em relação ao controle negativo. Nenhum dos grupos experimentais ( 3 a 5 ) foi significativamente diferente do grupo 1 (controle). O grupo 5 (canal de resina com pino metálico) foi mais resistente que o grupo 3 (canal de resina com pino plástico), mas não diferente do grupo 4 (canal de resina com pino opaco). Porém, a fratura no grupo 5 ocorreu ao nível do ápice do pino, contra-indicando o uso do pino metálico nestes casos.

Em 1998, HOLLIS et al. ${ }^{56}$ estudaram a resistência à fratura de dentes despolpados e restaurados com sete tipos de pinos. Os grupos controle foram dois: incisivos centrais superiores preparados, mas não restaurados e incisivos restaurados apenas com resina composta dual injetada no conduto, sem pino. Os pinos utilizados foram: 1) pino de fibras de carbono C-Post; 2) pino de fibras de carbono-quartzo Aestheti-Post; 3) pino de fibras de polietileno Ribbond; 4) pino de aço inoxidável ParaPost Plus; 5) pino de titânio puro Filpost; 6) pino de liga de titânio Para-Post Plus. Após tratamento endodôntico, removeu-se a coroa e fixaram-se os dentes em blocos de resina acrílica, $2 \mathrm{~mm}$ apicalmente à junção cemento-esmalte. Os pinos, cortados com $13 \mathrm{~mm}$ de comprimento, foram cimentados com cimento resinoso na profundidade de $9 \mathrm{~mm}$. Confeccionou-se a porção coronária com resina composta dual (5mm de altura). Após termociclagem, aplicaram-se cargas compressivas na face lingual do núcleo, em ângulo de $45^{\circ}$ com o longo eixo do pino, à velocidade de $1 \mathrm{~mm} / \mathrm{min}$. Todos os núcleos tiveram resistência significativamente maior que a da resina sem pino, exceto o núcleo de Ribbond (resistência similar à da resina sem pino). Todos os núcleos exibiram estatisticamente a mesma ou levemente mais resistência que a do dente preparado sem pino, exceto o de Ribbond e a resina sem pino (mais fracos). Os valores de resistência à fratura, em ordem decrescente, foram: pino de aço inoxidável - 69,13kgf; pino de titânio puro - 65,87kgf; pino de fibras de carbono - 64,75kgf; pino de liga de titânio - 63,52kgf; pino cerâmico - 62,91kgf; pino de fibras de carbono-quartzo e dente 
preparado sem pino - 57,92kgf; somente resina composta sem pino - 41,19kgf; núcleo de fibras de polietileno Ribbond e resina composta $-40,38 \mathrm{kfg}$. Com a resina sem pino normalmente ocorria fratura de raiz e deslocamento da porção coronária. No pino de Ribbond, as reconstruções coronárias eram lentamente esmagadas, e nos demais pinos geralmente fraturavam. Com o pino de Ribbond não houve fraturas dentárias. Com pinos metálicos, a média de fraturas radiculares foi de $47 \%$, enquanto com pinos não metálicos esta foi de $33 \%$, exceto para o Aestheti-Post (60\% de fratura dentária). Em um segundo teste, os pinos foram inseridos diretamente nos blocos acrílicos, sendo preparados três grupos (15 pinos cada). Não se utilizaram pinos de Ribbond nesta fase. O primeiro grupo (controle) foi submetido somente à fratura de forma similar à descrita no primeiro teste; o segundo foi submetido à fadiga (15.000 ciclos com cargas alternadas de $5-50 \mathrm{~N}$ ) antes da fratura; no terceiro, após a fadiga, os espécimes foram imersos em água a $37^{\circ} \mathrm{C}$ por 24 horas antes da fratura. Nenhum dos pinos foi afetado pelo teste de fadiga, mas após imersão em água os pinos cerâmicos, de fibras de carbono e de carbono-quartzo mostraram-se mais fracos que os demais. Concluiu-se que embora os pinos metálicos tenham apresentado maior resistência que os não-metálicos, todos os sistemas exibiram desempenho satisfatório para necessidades clínicas. Os menores valores com o pino de Ribbond foram provavelmente porque foi testada a resistência à compressão, sendo que fibras de polietileno não aumentam significativamente a resistência à compressão, mas principalmente à tração. Além disto, este pino possui vantagens em condutos largos e assimétricos.

No ano de 1998, GOLDBERG et al. ${ }^{46}$ avaliaram módulo de elasticidade, resistência à flexão até o limite elástico e resistência à flexão máxima de três fibras comerciais não-impregnadas (Ribbond, Connect e GlasSpan), comparando-as com o produto pré-impregnado FibreKor (considerado o grupo controle). Examinou-se a arquitetura das fibras com microscopia eletrônica de varredura antes da impregnação com adesivo sem carga. O conteúdo de fibras na matriz resinosa também foi determinado. Espécimes em forma de barras com 2x2x25mm foram preparados com as fibras paralelas ao seu longo eixo. Os resultados estão descritos na Tabela 2.2. 
TABELA 2.2 - Resistência à flexão até o limite elástico, resistência à flexão máxima e módulo de elasticidade de quatro fibras comerciais (GOLDBERG et al., 1998)

\begin{tabular}{l|c|c|c|c|c|c} 
Material & $\begin{array}{c}\text { Conteúdo } \\
\text { de fibras } \\
\text { (volume) }\end{array}$ & $\begin{array}{c}\text { Tipo de } \\
\text { fibra }\end{array}$ & $\begin{array}{c}\text { Arquitetura } \\
\text { da fibra }\end{array}$ & $\begin{array}{c}\text { Resistência } \\
\text { à flexão até } \\
\text { o limite } \\
\text { elástico } \\
\text { (MPa) }\end{array}$ & $\begin{array}{c}\text { Resistência } \\
\text { à flexão } \\
\text { máxima } \\
\text { (MPa) }\end{array}$ & $\begin{array}{c}\text { Módulo de } \\
\text { elasticidade } \\
\text { (GPa) }\end{array}$ \\
\hline FibreKor & 42,5 & Vidro & Unidirecional & 471 & 539 & 28,3 \\
\hline GlasSpan & 27,7 & Vidro & Trançada & 266 & 321 & 13,9 \\
\hline Ribbond & 41,7 & Polietileno & Entrelaçada & 56 & 206 & 3,9 \\
\hline Connect & 39,0 & Polietileno & Trançada & 50 & 222 & 8,3
\end{tabular}

O conteúdo de fibras foi similar entre Ribbond, FibreKor e Connect. A fibra de vidro com arquitetura unidirecional FibreKor atingiu o melhor desempenho. A resistência à flexão até o limite elástico das fibras de polietileno Ribbond e Connect foi significativamente menor que a da fibra de vidro FibreKor. As propriedades inferiores para Connect e Ribbond foram provavelmente devido à alta deformação que as fibras de polietileno sofrem sob compressão.

COHEN et al. $^{21}$, em 1999, compararam as propriedades retentivas e fotoelásticas dos pinos Flexi-Post (metálico e rosqueado) e C-Post (pino de fibras de carbono). Para o teste de retenção, utilizaram-se caninos ou incisivos com condutos preparados até $12 \mathrm{~mm}$ de profundidade para o Flexi-Post e até $11 \mathrm{~mm}$ para o C-Post (conforme indicações dos fabricantes). Cimentaram-se os pinos com fosfato de zinco e fixaram-se os dentes em blocos de resina acrílica, que foram armazenados por sete dias antes do teste de resistência à tração. Aplicou-se uma carga de 133,2N na máquina de ensaios sob duas condições: vertical e oblíqua (ângulo de $26^{\circ} \mathrm{com} o$ longo eixo da raiz), à velocidade de $0,63 \mathrm{~cm} / \mathrm{min}$. Os pinos foram também cimentados em blocos fotoelásticos simulando os condutos, sendo submetidos a cargas verticais ou oblíquas (quatro grupos, com 10 espécimes cada). Fotografaram-se os blocos antes e após a exposição à carga. O Flexi-Post foi significativamente mais retentivo (120kgf) que o C-Post (17,51kgf). A análise fotoelástica mostrou padrões de estresse apicais assimétricos para o C-Post, quando submetido a cargas verticais ou oblíquas. O Flexi-Post distribuiu o estresse simetricamente e de forma mais equitativa. Consideraram o último mais favorável pela distribuição simétrica do estresse e pela maior retentividade. 
MANNOCCl et al. ${ }^{79}$, em 1999, avaliaram a estrutura de pinos de fibras e a interface pino-cimento resinoso-dentina obtida utilizando-se dois sistemas adesivos diferentes. Distribuíram-se 42 pré-molares unirradiculares endodonticamente tratados em sete grupos (seis dentes cada). Em cinco dos grupos, utilizaram-se três tipos de pinos de fibras de carbono, pinos de fibras de quartzo e pinos de titânio combinados com sistema adesivo All Bond 2 e cimento resinoso C \& B. Em outros dois grupos, cimentaram-se dois tipos de pinos de fibras de carbono com cimento resinoso Panavia 21. Após 3 semanas armazenados em soro fisiológico, os dentes foram longitudinalmente seccionados, sendo uma metade avaliada por microscopia eletrônica de varredura e a outra por microscopia confocal. A microscopia confocal mostrou que com All Bond 2 a camada híbrida era melhor formada que com Panavia 21. O tamanho das fibras e estrutura dos pinos foram similares em todos os pinos de fibras. Alguns vazios estavam presentes na estrutura dos pinos de fibras.

Em 1999, STOCKTON ${ }^{128}$ ressaltou fatores importantes que afetam a retenção de pinos intra-radiculares, especialmente pinos metálicos. Quanto maior o comprimento do pino, maior a retenção; pinos com $3 / 4$ do comprimento da raiz são mais rígidos que pinos com $1 / 2$ ou $1 / 4$ do comprimento da raiz, além de que pinos curtos estão associados com altas taxas de falha. No entanto, em dentes curtos não se consegue tal comprimento sem prejuízo ao selamento apical. O aumento do diâmetro do pino não aumenta significativamente a retenção e diminui a resistência à fratura da raiz; um diâmetro de $1 / 3$ da raiz foi sugerido, bem como espessura mínima de $1 \mathrm{~mm}$ na ponta do pino. Pinos rosqueados são os mais retentivos (porém, pouco indicados pelo alto estresse que provocam na inserção), seguidos pelos pinos paralelos, sendo os pinos cônicos os menos retentivos. Pinos serrilhados são mais retentivos que lisos. Pinos cônicos produzem mais estresse no terço coronário do conduto e pinos paralelos mais estresse no ápice; os paralelos resistem melhor a forças de tração e cisalhamento que os cônicos e distribuem o estresse mais uniformemente ao longo da raiz. Pinos paralelos passivamente cimentados fornecem ótima retenção e baixo estresse, podendo ser indicados para a maioria dos dentes despolpados. Pinos em dentes anteriores superiores estão sujeitos a forças de cisalhamento em direção vestibular na interface dentina-pino, que aumentam a tendência ao deslocamento; preparos biselados aumentam a resistência ao deslocamento. A técnica de cimentação adequada é mais importante que o cimento usado. O fosfato de zinco fornece retenção confiável. lonômeros de vidro convencionais são fáceis de manipular, têm adesão química à dentina e resistência adequada. Cimentos resinosos possuem alta 
resistência à tração e compressão, união micromecânica à dentina e são indicados quando maior retenção é exigida, mas são altamente técnico-sensíveis. A colocação dos cimentos com lentulo no conduto é recomendada para cobertura uniforme do pino, sem bolhas, e maior retenção.

No ano de 1999, OURIQUE ${ }^{95}$ relatou a colagem de um fragmento dentário utilizando reforço intra-canal de fibras cerâmicas GlasSpan, em um paciente com fratura coronária do dente 21 ao nível subgengival e exposição pulpar. Após aumento da coroa clínica e tratamento endodôntico, preparou-se o conduto para receber o pino de fibras cerâmicas. Após biselamento da margens do preparo e do fragmento, ambos foram condicionados com ácido fosfórico, aplicando-se após o sistema adesivo. Preparou-se uma fibra cerâmica em forma de corda e preenchida com resina híbrida previamente polimerizada, com comprimento de $12 \mathrm{~mm}$, para ser introduzida no conduto. O cimento resinoso Enforce foi injetado no conduto para a cimentação da fibra. Utilizou-se resina fluida para substituir partes perdidas do fragmento. Segundo o autor, fibras cerâmicas aumentam significativamente a resistência da resina após a polimerização, pois, por serem condicionadas com ácido fluorídrico e pré-silanizadas durante a fabricação, formam um corpo único com a resina, funcionando efetivamente como núcleo de preenchimento.

ASMUSSEN; PEUTZFELDT; HEITMANN ${ }^{5}$, em 1999, determinaram a rigidez e resistência de pinos de zircônia (Biopost e Cerapost, ambos com 1,6mm de diâmetro), pinos de titânio (PCR de 1,6mm e 2,00mm) e pinos de fibras de carbono (Composipost de 1,4mm e 1,6mm). Cimentaram-se os pinos com cimento resinoso em condutos artificiais (de diâmetros correspondentes aos dos pinos) preparados em blocos de cobre, com profundidade que permitia aos pinos protuírem 4,8mm acima do conduto. Após armazenamento por 24 horas a $37^{\circ} \mathrm{C}$, submeteram-se os pinos a cargas em ângulo de $45^{\circ}$, à velocidade de $5 \mathrm{~mm} / \mathrm{min}$. Pinos cerâmicos mostraram maior resistência e maior rigidez que os demais pinos, sem nenhum comportamento plástico. O pino PCR foi tão resistente quanto pinos cerâmicos, mas menos rígido. Dos três pinos, o Composipost mostrou a menor rigidez e a menor resistência. $O$ comportamento dos pinos cerâmicos mostrou que são altamente friáveis, mas os pinos de titânio e de fibras de carbono mostraram certa quantidade de comportamento plástico. Salientou-se que as pesquisas têm mostrado que pinos menos rígidos distribuem melhor o estresse. 
MANNOCCI; FERRARI; WATSON ${ }^{76}$, em 1999, compararam o desempenho de dentes restaurados com pinos de fibras de quartzo (Aestheti-Plus), pinos de fibras de carbono-quartzo (Aestheti-Post) e pinos de dióxido de zircônia (Cerapost). Distribuíram igualmente 40 pré-molares inferiores endodonticamente tratados em três grupos experimentais e um grupo controle sem pino. O conduto foi preparado até $8 \mathrm{~mm}$ de profundidade. A porção coronária do núcleo foi construída com resina composta. Os dentes foram cobertos com coroas de cerâmica pura e fixados em blocos de resina acrílica. Aplicaram-se cargas intermitentes (dois ciclos por segundo) em ângulo de $45^{\circ} \mathrm{com}$ o longo eixo do dente. Ocorreu uma fratura com pinos de fibras de carbono-quartzo e uma fratura com pinos de fibras de quartzo (fratura da raiz mais pino); com pinos de zircônia houve seis fraturas (uma fratura de coroa e cinco fraturas de raiz mais pino). A taxa de sobrevivência de dentes com pinos cerâmicos foi significativamente menor que nos outros grupos. Todos os grupos mostraram taxa de sobrevivência maior que a do grupo sem pinos, indicando ser necessário um pino para suportar o material da porção coronária do núcleo quando toda a coroa dentária é perdida. Pinos de fibras reduziram significativamente o risco de fratura da raiz, e as fraturas foram favoráveis à manutenção da raiz (ocorreram na altura em que estaria a gengiva marginal). $O$ alto módulo de elasticidade dos pinos cerâmicos em relação à dentina foi provavelmente a causa do alto índice de fratura. $O$ comportamento mecânico dos pinos de fibras estéticas foi similar ao dos pinos de fibras de carbono.

Em 1999, RUDO; KARBHARI ${ }^{111}$ relataram que desde 1991 a fibra de polietileno Ribbond tem sido utilizada com sucesso. A adição destas fibras à resina composta aumenta significativamente sua resistência à compressão e à fratura. As principais propriedades destas fibras são: (1) alta resistência à tração; (2) alto módulo de elasticidade; (3) absorção de água menor que 1\%; (4) quimicamente inertes a quase todos os solventes, ácidos ou substâncias alcalinas; (5) biocompatibilidade; (6) facilmente conformáveis; (7) opticamente transparentes após embebidas em resina. 0 Ribbond possui configuração entrelaçada: além das fibras paralelas, há outras que correm perpendicularmente e passam entre as paralelas, unindo-as e dificultando o desfiamento da fita. As fibras de polietileno hidrofóbicas são convertidas em hidrofílicas pelo tratamento por plasma de gás oxigênio, aumentando sua impregnação pela resina. O gás parcialmente ionizado age através de ablação e ativação. $O$ processo de ablação funciona como o condicionamento ácido (por remoção). A ativação é observada pela presença de grupos funcionais $\mathrm{O}-\mathrm{C}=\mathrm{O}$ na superfície das 
fibras. Assim, o mecanismo pelo qual o tratamento com plasma aumenta a adesão entre fibras e resina é a união química. As fibras devem ser impregnadas com adesivo de esmalte sem carga. Devem ser evitados adesivos com carga, que são viscosos e não penetram adequadamente nas fibras. Se manipulados para penetrar nas fibras, há incorporação de bolhas de ar com o adesivo.

SIRIMAI; RIIS; MORGANO ${ }^{119}$, em 1999, avaliaram a resistência à fratura e incidência de fratura vertical em raízes tratadas endodonticamente e restauradas com seis tipos de núcleos. Prepararam-se os condutos de 60 incisivos centrais superiores até $1,6 \mathrm{~mm}$ de diâmetro e removeu-se a coroa dentária ao nível da junção cemento-esmalte. As raízes foram fixadas em blocos de resina acrílica. Formaram-se seis grupos (10 espécimes cada): Grupo 1 - núcleo metálico fundido, cimentado com fosfato de zinco; Grupo 2 - pino de titânio paralelo e serrilhado VarioPassive com 1,6mm de diâmetro, cimentado com fosfato de zinco; assim como nos grupos 3 a 6, confeccionou-se a porção coronária do núcleo com resina composta dual para núcleos Magnacore, associada ao sistema adesivo Syntac; Grupo 3 - pino de fibras de polietileno Ribbond e resina Heliobond; assim como nos grupos 4 e 5, utilizou-se para cimentação o cimento resinoso dual Variolink; Grupo 4 - pino de titânio puro Vario-Passive com diâmetro de 1,2mm envolvido por Ribbond; Grupo 5 pino de liga de titânio de $1,25 \mathrm{~mm}$ Para-Post Plus $\mathrm{n}^{\circ} 5$ envolvido por Ribbond; Grupo 6 - pino Para-Post Plus $n^{\circ} 5$. Aplicou-se a carga de compressão em ângulo de $130^{\circ}$ com o longo eixo do dente na máquina de ensaios, à velocidade de $0,5 \mathrm{~mm} / \mathrm{min}$. Os resultados são apresentados na Tabela 2.3.

TABELA 2.3 - Médias de resistência à fratura e desvios padrão para cada grupo experimental (SIRIMAI; RIIS; MORGANO, 1999)

\begin{tabular}{c|c} 
Grupo experimental & Limiar de carga para falha (kgf) \\
\hline Grupo 1 & 29,43 \\
\hline Grupo 2 & 25,97 \\
\hline Grupo 3 & 12,95 \\
\hline Grupo 4 & 22,26 \\
\hline Grupo 5 & 23,82 \\
\hline Grupo 6 & 20,53
\end{tabular}


Todas as falhas no grupo 1 (núcleos metálicos fundidos) envolveram fratura dentária, enquanto $70 \%$ dos dentes com pinos pré-fabricados paralelos (grupo 2) falharam devido à fratura dentária e $30 \%$ devido à fratura da porção coronária. No grupo 3 (núcleo de Ribbond sem pino metálico), a resistência à fratura foi significativamente menor que nos demais grupos, mas o número de raízes fraturadas foi significativamente menor (uma fratura vertical e uma fratura horizontal no terço cervical da raiz); os demais espécimes falharam por fratura ou deslocamento da porção coronária do núcleo. Envolvimento com Ribbond dos pinos metálicos de diâmetro menor que o do conduto (grupos 4 e 5) aumentou a resistência em relação à utilização unicamente destes pinos (grupo 6) ou à utilização de fibras de polietileno sem pino metálico (grupo 3), além de serem evidenciadas menos fraturas radiculares que com núcleos metálicos fundidos (grupo 1); a resistência, porém, foi menor que a do grupo 1 e similar à do grupo 2 .

Em 1999, SOARES ${ }^{120}$ comparou a resistência à fratura de raízes hígidas restauradas com núcleo metálico fundido com a resistência de raízes debilitadas reconstruídas com três sistemas restauradores e núcleo metálico fundido. Distribuiu 56 incisivos centrais e caninos superiores em quatro grupos: 1) raiz hígida com núcleo metálico fundido (controle); 2) raiz debilitada restaurada com resina composta fotopolimerizável Z100; 3) raiz debilitada restaurada com cimento de ionômero de vidro Vitremer; 4) raiz debilitada restaurada com resina composta autopolimerizável Bisfil II. Após tratamento endodôntico, removeram-se as coroas e executou-se um desgaste interno padronizado para simular enfraquecimento das raízes (espessura de $0,5 \mathrm{~mm}$ das paredes radiculares no terço cervical). As raízes foram preenchidas internamente com o material restaurador, utilizando-se pino fototransmissor Luminex para auxiliar na fotopolimerização. No grupo controle, utilizouse uma broca de $1,5 \mathrm{~mm}$ de diâmetro do sistema Luminex para preparo do conduto até $8 \mathrm{~mm}$ de profundidade. As raízes foram fixadas em blocos acrílicos, os núcleos cimentados com fosfato de zinco e armazenados por 24 horas em água deionizada à temperatura ambiente. Aplicou-se uma carga de compressão na máquina de ensaios, na face palatina do núcleo, em ângulo de $45^{\circ} \mathrm{com}$ o plano horizontal. Em ordem decrescente, os sistemas mais resistentes à fratura foram: grupo 1, grupo 2, grupo $4 \mathrm{e}$ grupo 3. Não houve diferença significativa entre as resinas Z100 e Bisfil II. O ionômero de vidro apresentou a menor resistência (diferença significativa com os demais grupos). Nenhum dos procedimentos restauradores recuperou a resistência original da 
raiz. Nas raízes debilitadas, todos os espécimes fraturaram; no grupo controle fraturaram $78,6 \%$ das raízes.

OURIQUE ${ }^{96}$, em 2000, confeccionou um núcleo intra-canal em dente estruturalmente debilitado com fibras cerâmicas GlasSpan. Um paciente necessitava de restauração do dente 13 , cujo núcleo metálico fundido havia se deslocado por recidiva de cárie. Após preparo do conduto, selecionou-se um comprimento de fibra cerâmica em forma de corda suficiente para ser dobrada sobre si mesma e introduzida no conduto para reforçar o cimento resinoso dual. Procedeu-se ao corte da corda e tratamento adesivo conforme orientação do fabricante, mantendo-a protegida da luz até o uso. Após condicionamento ácido e aplicação do sistema adesivo no canal, injetou-se o cimento em seu interior e na luz da corda de GlasSpan, até extravasamento entre as fibras. Acomodou-se a corda dobrada ao meio no conduto. Em torno das pontas que emergiam do conduto, adicionou-se resina composta para confecção da porção coronária do núcleo. O autor ressaltou que a facilidade de manuseio destas fibras, associada à utilização de materiais de uso rotineiro, facilita e acelera a reconstrução dental, diminuindo custos. Recomendou estudos adicionais para observação de resultados a longo prazo.

A restauração de dentes tratados endodonticamente com fibras de polietileno Ribbond foi discutida por íñIGUEZ ${ }^{59}$, em 2000. Este tipo de núcleo, além de fornecer retenção para a coroa, também reforça os dentes, pois é constituído por elementos adesivos entre si e com propriedades similares (estrutura dentária, fibras e resina composta), resultando em um bloco sólido e com reflexão da luz idêntica à do dente natural. A propagação de fraturas verticais é virtualmente eliminada. A técnica é simples e econômica, sendo indicada sobretudo para dentes despolpados que não necessitam de núcleos (quando há $50 \%$ de dentina em dentes anteriores ou $30 \%$ em dentes posteriores, além de haver pelo menos $2 \mathrm{~mm}$ de estrutura dentária natural). Descreveu a seguinte técnica: desobturação do terço cervical do conduto e isolamento do material obturador com $1 \mathrm{~mm}$ de fosfato de zinco aplicado com seringa Centrix. Normalmente se utilizam fitas de Ribbond com $2 \mathrm{~mm}$ de largura. Mede-se a profundidade do conduto e corta-se a fita com o triplo dessa medida. Cobre-se a fita com adesivo, executa-se condicionamento ácido do conduto, aplica-se sistema adesivo dual e injeta-se no conduto um cimento resinoso também dual. A fita de Ribbond é condensada no conduto e, se o espaço permitir, insere-se no conduto outra fita, perpendicular à primeira, agregando-se mais cimento. As pontas que emergem do 
conduto são dobradas sobre si mesmas e também condensadas no conduto. Acrescenta-se mais cimento e polimeriza-se o conjunto. $O$ autor utilizou a técnica em cerca de 500 casos, com poucos fracassos, atribuídos a erros na técnica adesiva.

Em 2000, XIBLE ${ }^{138}$ comparou a resistência adesiva ao cisalhamento de três sistemas de núcleos. Utilizou pinos cerâmicos de dióxido de zircônia (Cosmopost) e pinos de titânio (Tenax). Constituíram-se três grupos com 10 espécimes cada: 1) pinos cerâmicos aos quais foi fundida porcelana vítrea (IPS Empress Post); 2) pinos cerâmicos e porção coronária de resina composta fotopolimerizável Tetric Ceram; e 3) pinos de titânio e porção coronária com a mesma resina do grupo 2. Submeteram-se os espécimes a forças de cisalhamento na máquina de ensaios até a fratura. Concluiuse que o grupo 3 apresentou os maiores valores numéricos de resistência adesiva, porém sem diferença estatisticamente significativa com o grupo 1. Os grupos 1 e 3 apresentaram diferença estatisticamente significativa em relação ao grupo 2 , que apresentou os menores valores de adesão.

FERRARI et al. $^{36}$, em 2000, avaliaram a dentina radicular quanto à densidade e orientação dos túbulos dentinários, bem como o aumento na área de superfície após condicionamento ácido. Distribuíram 30 dentes anteriores em 3 grupos. No grupo 1, utilizaram-se os dentes para estudo da morfologia tubular original por microscopia eletrônica de varredura (MEV). Nos grupos 2 e 3, condicionaram-se condutos radiculares preparados até $9 \mathrm{~mm}$ de profundidade com ácido fosfórico a $32 \%$. Os dentes do grupo 2 foram examinados por MEV somente com o condicionamento ácido. Nos condutos do grupo 3, aplicou-se também sistema adesivo All-Bond 2 e cimentaram-se pinos de fibras de carbono RTD com cimento resinoso $C \& B$, avaliando-se a formação da camada híbrida e dos tags de resina nos túbulos dentinários com MEV. No terço cervical, a densidade dos túbulos foi significativamente mais alta que nos terços médio e apical do conduto. O diâmetro dos túbulos diminuía em direção apical, mas em qualquer área sempre aumentava após condicionamento. A área de dentina disponível para adesão aumentou em $202 \%$ após condicionamento no terço cervical do conduto, $156 \%$ no terço médio e $113 \%$ no terço apical. A espessura da camada híbrida dependeu da densidade dos túbulos. Em áreas com baixa densidade de túbulos, a camada híbrida era mais fina que em áreas com maior densidade. 
O'KEEFE; MILLER; POWERS ${ }^{93}$ mediram, em 2000, a resistência adesiva de pinos de aço inoxidável, de fibras de carbono, de titânio e de dióxido de zircônia a três cimentos resinosos (Panavia 21, C \& B Metabond e Bis-Core). Distribuíram-se os pinos em três grupos (um para cada cimento) de cinco espécimes cada. A partir dos pinos, obtiveram-se discos que foram polidos e abrasionados com com óxido de alumínio (50 $\mu$ ). A superfície dos discos cerâmicos foi ainda tratada com ácido hidrofluorídrico a $8 \%$ e silanizada. Aplicaram-se cones de cimento com $3 \mathrm{~mm}$ de diâmetro e $5 \mathrm{~mm}$ de altura aos discos, que foram armazenados em umidificador a $37^{\circ} \mathrm{C}$ por 24 horas. Os espécimes foram submetidos à tração na velocidade de $0,5 \mathrm{~mm} / \mathrm{min}$ em máquina de ensaios, até o deslocamento do cimento. A maior resistência adesiva foi vista com Panavia 21 para todos os pinos. O C \& B Metabond ficou em segundo lugar, com adesão significativamente maior para aço inoxidável e titânio, e o menor valor para dióxido de zircônia. Os resultados mais baixos de resistência adesiva foram obtidos com Bis-Core. Na maioria dos casos, a adesão a pinos de fibra de carbono foi menor que ao aço e ao titânio, mas maior que ao dióxido de zircônia (menores valores de adesão). Quanto mais alta a adesão, maior foi a porcentagem de falhas coesivas dentro do cimento; falhas adesivas ocorreram mais com Bis-Core e todos os pinos, seguidos de C \& B Metabond e pino de dióxido de zircônia e finalmente com Panavia 21 e pinos de fibras de carbono.

GLAZER $^{44}$, em 2000, relatou um estudo para avaliar clinicamente pinos de fibras de carbono (Composipost e Endopost) cimentados em 52 dentes $(71,2 \%$ inferiores e $28,8 \%$ superiores), sendo $30,8 \%$ incisivos, $25 \%$ caninos e $44,2 \%$ prémolares. Todos os dentes tinham menos de $50 \%$ da estrutura coronária. Coroas unitárias englobaram $51,9 \%$ da amostra e retentores de próteses parciais fixas $48,1 \%$ da mesma. Utilizou-se cimento resinoso e confeccionou-se a porção coronária do núcleo com resina composta dual. Os dentes receberam coroas metalo-cerâmicas e acompanhamento pelo período médio de 28 meses. A taxa de sobrevivência foi de $89,6 \%$. Falhas ocorreram em três dentes com coroas unitárias e um retentor de prótese parcial fixa (dois pré-molares inferiores, um pré-molar superior e um canino superior). Duas falhas foram biológicas (patologia periapical) e duas mecânicas (um deslocamento de coroa e um deslocamento de núcleo), nenhuma delas comprometendo o elemento dentário. Os pinos apresentaram mais falhas em prémolares inferiores. Concluiu-se que pinos de fibras de carbono estão entre os mais previsíveis atualmente e que sua utilização em dentes anteriores superiores está associada com alto padrão de sucesso. 
De acordo com FREILICH et al. ${ }^{41}$, em 2000, compósitos reforçados com fibras são formados por um componente de reforço (fibras de vidro, polietileno ou carbono), que fornece resistência e rigidez, e por uma matriz resinosa ou polimérica, que suporta o reforço e proporciona características de manipulação adequada. As fibras podem ser arranjadas em configurações unidirecionais (longas e paralelas), trançadas ou entrelaçadas. Compósitos reforçados por fibras são anisotrópicos, isto é, reagem de forma diferente de acordo com a direção da carga. Suas propriedades são melhores quando as fibras estão organizadas paralelamente com a direção do estresse mais alto recebido pela estrutura. Uma quantidade de fibras na resina de pouco menos que $50 \%$ do volume total parece permitir a obtenção de módulo de elasticidade suficientemente alto para suportar as estruturas aplicadas sobre os compósitos reforçados por fibras; acima deste valor, a impregnação das fibras pela resina pode ser incompleta. Fibras de polietileno entrelaçadas são as mais fáceis de manipular, devido ao seu arranjo e ao baixo módulo de elasticidade sob compressão. Pinos de fibras podem ser pré-fabricados em fibras de carbono ou em fibras de vidro, ou então construídos diretamente no conduto com fibras de polietileno (Ribbond, Connect, etc) ou fibras de vidro (como GlasSpan). Pinos de fibras oferecem maior flexibilidade e resistência à fadiga que pinos metálicos, módulo de elasticidade similar ao da dentina, capacidade de formar um complexo único com o remanescente dentário através da adesão e melhor estética. Possuem ainda potencial de reforçar raízes comprometidas e distribuir o estresse uniformemente, prevenindo a fratura da raiz (geralmente fraturam antes que a raiz). Descreveu a seguinte técnica para confecção de pinos de fibras diretamente no conduto: remoção da obturação radicular até cerca de $5 \mathrm{~mm}$ do ápice, não sendo preciso alterar a forma do conduto. Cortam-se fitas com mais de duas vezes o comprimento do conduto, que são dobradas em forma de letra "V" e saturadas com adesivo (quando não são pré-impregnadas). Após condicionamento ácido e aplicação do sistema adesivo no conduto e remanescente dentário, aplica-se cimento resinoso autopolimerizável ou dual às paredes do canal. Leva-se a fibra ao canal, mantendo uma porção para fora deste. Condensam-se fibras no conduto até seu preenchimento completo. Aplica-se resina composta híbrida sobre as extensões coronárias das fibras para construir a porção coronária do núcleo.

A associação entre fibras em forma de fita e um pino de fibras préfabricado para construção de um núcleo intra-radicular foi proposta pela primeira vez por $\mathrm{KIMMEL}^{67}$, em 2000. O autor afirmou que para dentes com canais muito largos são contra-indicados núcleos metálicos fundidos, pois a concentração de estresse no 
interior da raiz e o efeito de cunha podem gerar fratura da raiz. Pinos pré-fabricados adaptam-se bem apenas no terço apical do canal, mas mostram má adaptação no terço cervical, dependendo de grande quantidade de cimento para retenção do pino. As fibras de polietileno Ribbond são biocompatíveis e translúcidas. Sua arquitetura entrelaçada Ihes fornece ótima flexibilidade e as torna virtualmente livres de memória elástica. $O$ tratamento superficial com plasma permite baixo ângulo de contato entre fibra e adesivo, aumentando o "molhamento" da fibra e favorecendo a incorporação da fibra à resina composta. Para reforço de dentes com canais alargados, o autor recomendou a técnica a seguir. Inicialmente é feita a desobturação parcial do conduto. A embocadura do conduto é arredondada para melhor assentamento da fita e do pino pré-fabricado, sem formação de espaços vazios. Com uma radiografia periapical, seleciona-se o pino de fibras de vidro, levando-se também em conta que a espessura do Ribbond é $0,33 \mathrm{~mm}$. O remanescente dentário é tratado com sistema adesivo. A fita impregnada com adesivo e coberta com cimento resinoso dual ou autopolimerizável é levada ao conduto. Com um condensador endodôntico, o Ribbond é compactado até a porção apical do conduto e lateralmente contra suas paredes. A seguir, o pino de fibra de vidro jateado com óxido de alumínio é coberto com cimento e inserido entre as fibras. Antes da polimerização total, comprime-se resina composta no canal e em torno do pino, bem como entre as fitas projetadas para fora do canal, formando a base do núcleo. O conjunto é fotopolimerizado e executa-se o preparo para coroa total.

Ainda no ano de 2000, KIMMEL $^{68}$ destacou que a utilização de fibras de polietileno para confecção de núcleos de preenchimento exige mínima remoção da estrutura dentária remanescente e proporciona um pino que fornece suporte e reforço interno da raiz, possibilitando o aproveitamento de raízes com paredes finas. A união química entre as paredes internas do conduto e os materiais restauradores cria um monobloco adesivo estável, que pode deter trincas e microfraturas já existentes, prevenindo sua extensão até o periodonto.

FERRARI et al. $^{35}$, em 2000, investigaram por um a seis anos o desempenho clínico de 1.304 dentes tratados endodonticamente e restaurados com pinos de fibras de carbono C-Post $(n=840$ ), pinos de fibras de carbono-quarzo Aestheti-Post $(n=215)$ e pinos de fibras de quarzo Aestheti Plus $(n=249)$. A idade média dos pacientes era de 53 anos. Restauraram-se 55 incisivos centrais, 54 incisivos laterais, 36 caninos, 56 pré-molares e 58 molares. O tempo médio de serviço clínico foi: C-Post $=46$ meses; Aestheti-Post $=14$ meses e Aestheti Plus $=13$ meses. 
As restaurações finais incluíram coroas metalo-cerâmicas (52\%), coroas de cerâmica pura $(38 \%)$ e restaurações diretas de resina composta (38\%). Prepararam-se os condutos até $8 \mathrm{~mm}$ de profundidade. Somente um pino foi colocado nos molares. Utilizaram-se quatro combinações de sistemas adesivos e cimentos resinosos: adesivo All-Bond 2 ou One-Step com cimento C \& B Resin Cement; adesivo Scotchbond MultiPurpose Plus com cimento Opal; ou adesivo Single-Bond com cimento RelyX ARC. Para a porção coronária dos pinos utilizou-se resina composta auto-polimerizável (com pinos C-Post e Aestheti-Post) ou resina composta fotopolimerizável (com pinos Aestheti Plus). Os pacientes foram rechamados a cada seis meses para avaliação clínica e radiográfica. A taxa de falha foi de $3,2 \%$, sendo que houve deslocamento de 25 pinos (todos em dentes com menos de $2 \mathrm{~mm}$ de remanescente coronário) e 16 dentes mostraram lesões periapicais. Não houve diferenças significativas na distribuição das falhas entre as quatro combinações de materiais cimentantes. Em nenhum dos casos houve prejuízo ao remanescente dentário e os mesmos tratamentos foram refeitos. Os resultados indicaram que os pinos de fibras e materiais para cimentação testados podem ser rotineiramente usados.

JIMENÉZ ${ }^{61}$, em 2001, afirmou que os pinos de fibras de vidro são mais práticos, estéticos, econômicos e conservadores do que os núcleos metálicos fundidos. São biocompatíveis, resistentes à corrosão e fratura, e de fácil remoção. Sua capacidade de adesão à dentina e a materiais resinosos permite reconstruir dentes com condutos alargados, formando um monobloco que, juntamente com o módulo de elasticidade similar ao da dentina, auxilia a distribuir o estresse ao longo da raiz. Sua incorporação às resinas aumenta sua dureza e resistência ao desgaste. Na segunda metade da década de 1990, surgiram pinos mais estéticos que os pinos de fibras de carbono: U.M. Aestheti-Plus (branco e paralelo), Aestheti-Plus (branco e cônico) e Light-Post (cônico e transparente, capaz de transmitir luz). Comentou sobre os pinos de fibras de vidro mais usados: 1) Fibrekor - diâmetros de 1mm, 1,25mm e 1,5mm; cônicos, brancos e serrilhados; capazes de transmitir luz para polimerizar o cimento resinoso; aderem à estrutura dentária; 2) Dentatus Luscent Anchors - diâmetros de $1,4 \mathrm{~mm}, 1,6 \mathrm{~mm}$ e $1,8 \mathrm{~mm}$; translúcidos, lisos e cônicos; transmitem luz; tratados quimicamente para adesão à resina. Pinos de fibras podem ser construídos diretamente nos canais, nos quais são inseridas fibras de vidro ou polietileno; a técnica é ideal para condutos amplamente alargados. Apesar dos ótimos resultados clínicos relatados com a última aplicação, a mesma necessita de estudos adicionais. 
FERRARI et al. ${ }^{37}$, em 2001, avaliaram a eficácia de diferentes combinações de sistemas adesivos e cimentos resinosos na formação de tags de resina, na extensão da camada híbrida e ramificações laterais de adesivo quando usados para cimentação de pinos de fibras. Distribuíram 30 dentes anteriores tratados endodonticamente em três grupos (10 espécimes cada): 1) sistema adesivo fotopolimerizável Excite, combinado com cimento resinoso dual Variolink II; 2) sistema adesivo dual Excite Dual Self-Cure, combinado com cimento resinoso autopolimerizável MultiLink; e 3) sistema adesivo fotopolimerizável One-Step, combinado com cimento resinoso dual Dual Link. Nos grupos 1 e 3, fotopolimerizou-se o adesivo da inserção do cimento; no grupo 2, o adesivo e o cimento não foram fotopolimerizados. Utilizaram-se pinos de fibras de vidro translúcidos nos três grupos (FRC Postec nos grupos 1 e 2 e EndoAesthetic no grupo 3). Após sete dias armazenados em água, os espécimes foram seccionados paralelamente ao longo eixo do dente. Preparou-se metade da raiz para observar a formação da camada híbrida na interface adesiva, e na outra metade dissolveu-se o substrato dental para detectar a formação de tags de resina e ramificações laterais de adesivo. A microscopia eletrônica de varredura revelou uma camada híbrida melhor formada e mais tags de resina nos espécimes do grupo 2 que naqueles dos grupos 1 e 3 , inclusive nos terços médio e apical do conduto. Concluiu-se que o sistema adesivo dual proporcionou formação mais uniforme de ramificações laterais e tags de resina, bem como uma camada híbrida melhor formada e mais extensa que a obtida com sistemas fotopolimerizáveis.

BOUDRIAS; SAKKAL; PETROVA ${ }^{15}$, em 2001, ressaltaram que a adaptação dos pinos às paredes do conduto é importante para o adequado desempenho biomecânico da restauração. Relataram que visando uma melhor adaptação dos pinos ao conduto, tanto no terço apical quanto cervical, foram desenvolvidos pinos de fibras de quartzo com dois estágios de conicidade: o D.T. Light-Post (translúcido) e o D.T. White-Post (branco). Alguns dos benefícios dos pinos são: mínima remoção de estrutura dentária durante preparo do conduto, baixo módulo de elasticidade, não interfere na difusão da luz através da estrutura dentária e não altera a cor de restaurações livres de metal. Estes novos pinos estéticos possuem propriedades mecânicas similares às de pinos de carbono e desenho próximo à forma cônica dos condutos. Já pinos paralelos necessitam de alargamento excessivo no terço apical do conduto, enquanto no terço cervical permanece um espaço vazio em torno do pino, que será preenchido por cimento. O pino ideal deve possuir forma 
similar à do conduto instrumentado, exigindo mínimo preparo. Para auxiliar a determinar a forma dos pinos, registraram-se as medidas mesiodistal e vestibulolingual a $5 \mathrm{~mm}$ e $10 \mathrm{~mm}$ do ápice, e na junção cemento-esmalte, em 967 dentes extraídos (11 tipos de dentes) tratados endodonticamente, com auxílio de radiografias. Respeitou-se no sistema D.T. Light-Post a dupla conicidade (terço apical menos cônico que o cervical) dos condutos. O sistema possui pinos com três diâmetros nos $5 \mathrm{~mm}$ apicais: ISO 90, 100 e 120. Do terço apical à junção cemento-esmalte, os pinos aumentam em conicidade e diâmetro.

BONILLA $^{13}$, em 2001, avaliou a resistência à fratura de raízes amplamente destruídas reconstruídas internamente ou não com resina composta e restauradas com núcleos metálicos fundidos, bem como a resistência à fratura de raízes amplamente destruídas restauradas com pinos dentários. Distribuiu 40 caninos superiores em quatro grupos (10 dentes cada): (1) raiz íntegra com núcleo metálico fundido; (2) raiz amplamente destruída com núcleo metálico fundido; (3) raiz amplamente destruída reconstruída com resina composta e núcleo metálico fundido; e (4) raiz amplamente destruída reconstruída com pino dentário. Removeram-se as coroas dentárias e os condutos foram obturados. No grupo 1, preparou-se o conduto para receber núcleo metálico fundido. Nos grupos 2, 3 e 4, foi executada seqüência padronizada de desgaste para simular uma raiz amplamente destruída, com espessura de parede de $0,5 \mathrm{~mm}$ no terço cervical. No grupo 2, confeccionaram-se núcleos metálicos fundidos. No grupo 3 , as raízes foram reconstruídas com resina composta fotopolimerizável para núcleos Build-lt!, polimerizada através de pino fototransmissor Luminex, criando um novo conduto que foi preparado para receber núcleo metálico fundido. O grupo 4 recebeu pinos dentários obtidos a partir de dentes naturais. As raízes foram incluídas em blocos acrílicos e os núcleos cimentados com cimento resinoso. Os espécimes foram armazenados por 24 horas em água deionizada à temperatura ambiente. Executaram-se os testes de resistência à fratura sob compressão na máquina de ensaios à velocidade de $0,5 \mathrm{~mm} / \mathrm{min}$, incidindo na face lingual do núcleo, em ângulo de $135^{\circ}$ com o longo eixo da raiz. Os valores de resistência à fratura foram (em ordem crescente): (1) Grupo 3 -53,98kgf; (2) Grupo 2 - 57,64kgf; (3) Grupo 4 - 76,35kgf; e (4) Grupo 1 - 87,59kgf. Não houve diferença significativa entre os grupos 1 e 4 , nem entre os grupos 2 e 3 . Os valores encontrados para os grupos 2 e 3 foram 30\% menores que os dos grupos 1 e 4 (diferença significativa). 
FERRARI; VICHI; GRANDINI ${ }^{34}$, em 2001, estudaram a influência de quatro técnicas adesivas sobre a formação da camada híbrida e dos tags de resina na dentina. Distribuíram 40 dentes anteriores superiores despolpados em quatro grupos (10 espécimes cada): 1) sistema adesivo fotopolimerizável One Step aplicado com um pincel (microbrush) fino e polimerizado antes da aplicação do pino e do cimento resinoso dual Dual Link; 2) sistema adesivo One Step aplicado com pincel ainda mais fino que o dos demais grupos e polimerizado antes da inserção do pino e do cimento resinoso Dual Link; 3) sistema adesivo One Step aplicado com pincel fino e não fotopolimerizado antes da aplicação do cimento resinoso Dual Link (foi fotopolimerizado através do pino translúcido); 4) sistema adesivo dual All Bond 2 e cimento resinoso autopolimerizável C \& B. Prepararam-se os condutos com 9mm de profundidade. Nos grupos 2 e 4, utilizaram-se os materiais como recomendado pelo fabricante. Em todos os grupos, cimentaram-se pinos de fibras de vidro translúcidos através dos quais se executou a polimerização final do cimento por 20 segundos. Após sete dias armazenados em água, seccionaram-se os espécimes paralelamente ao longo eixo do dente. Preparou-se metade da raiz para observar a formação da camada híbrida, e na outra dissolveu-se o substrato dental para detectar a formação de tags de resina. A microscopia eletrônica de varredura mostrou uma camada híbrida mais extensa na interface pino-dentina do grupo 1 que nos demais grupos. Não houve diferença entre os grupos quanto à quantidade de tags de resina no terço cervical do conduto, mas nos terços médio e apical do grupo 1 havia mais tags de resina que nos demais grupos. Da mesma forma, nos grupos 2, 3 e 4, a camada híbrida era facilmente detectada nos terços cervical e médio do conduto, mas não estava uniformemente presente no terço apical. No terço apical dos grupos 2, 3 e 4, os tags de resina eram mais curtos que nos outros dois terços. Concluiu-se que um pincel fino deve ser usado para melhorar a adesão de pinos de fibras ao conduto, pois possibilitou uma adesão mais uniforme e mais previsível ao longo dos condutos.

SILVA E SOUZA JÚNIOR et al. ${ }^{117}$, em 2001, descreveram a confecção de núcleos com fibras de polietileno do sistema Ribbond, constituído por fitas com larguras de 1, 2, 3, 4 e 9mm. O fabricante indica fitas de $1 \mathrm{~mm}$ para reforço intraradicular, mas larguras maiores podem ser usadas em condutos largos. Relataram um caso em que o dente 21 teve a maior parte da coroa destruída. Desobturou-se parcialmente o conduto e executou-se apoio para o núcleo na embocadura do canal, com broca diamantada esférica 1016, para evitar rotação do pino. Seguiu-se condicionamento ácido do conduto e aplicação do sistema adesivo. Uma fita de 
Ribbond de $2 \mathrm{~mm}$ de largura foi impregnada com adesivo; são desaconselháveis agentes de união associados ao "primer" (monocomponentes). A fita foi introduzida e compactada no conduto (já preenchido por cimento resinoso), buscando-se a melhor adaptação possível a suas paredes. A seguir, cortou-se o feixe de fibras ligeiramente acima do comprimento desejado para a porção coronária do núcleo. A extremidade do feixe foi presa com porta-agulha e, com movimento de rotação, enrolou-se a fita até apresentar-se firme. Aplicou-se resina composta ao redor e entre as fibras para formar a porção coronária do núcleo.

Em 2001, FELIPPE et al. ${ }^{32}$ afirmaram que fibras de reforço possuem alta resistência quando agrupadas em forma de fitas. Seu propósito é reforçar grandes volumes de resina, polímero ou cerômero. Auxiliam a distribuir e dissipar as forças na estrutura à qual são incorporadas, diminuindo o estresse. Se utilizadas para confecção de núcleos, conduziriam a luz do fotopolimerizador. As fibras mais utilizadas são as de vidro, polietileno, cerâmica e carbono. Fibras de vidro e de polietileno possuem características clínicas similares e são as mais apropriadas para uso em forma de fita. São leves, não oxidam e sua translucidez favorece a estética. O direcionamento das fibras influi na resistência da estrutura reforçada. $O$ ideal é incorporar fibras transversais e longitudinais, pois fibras dispostas paralelamente em relação às forças aplicadas sobre a estrutura absorvem melhor as cargas; deve-se considerar que as forças atuam nos dentes tanto no sentido axial (paralelo ao longo eixo) quanto transversal (perpendicular ao longo eixo). O Ribbond, o Splint-It e o Vectris são fitas com fibras tanto em direção longitudinal quanto transversal; o Connect e o GlasSpan apresentam fios longitudinais trançados; o Splint-It apresenta ainda uma versão longitudinal com fios paralelos. O direcionamento das fibras também influencia na manipulação. Produtos com fios longitudinais desfiam facilmente, enquanto uma arquitetura entrelaçada evita desfiamento. A memória elástica dos fios (capacidade de voltar à posição original após deflexão) também influencia na manipulação. Fios com alta memória são de inserção mais difícil. Quanto maior a impregnação das fibras (união molecular entre fibras e matriz resinosa), maior a resistência. Em produtos préimpregnados, a fibra já vem incorporada na matriz resinosa, proporcionando maior rapidez de trabalho, fácil utilização e maior resistência final. A quantidade e a distribuição das fibras influenciam na resistência da estrutura. Um volume de $45 \%$ de fibras na estrutura resinosa é o suficiente (distribuídas o mais homogeneamente possível); o excesso de fibras compromete o molhamento. A fibra deve ficar totalmente coberta por resina, pois se exposta há acúmulo de placa, pigmentação, degradação da 
resina por infiltração de líquidos e irritação gengival. Em fibras acidentalmente expostas, executa-se novo tratamento adesivo e recobrimento com nova camada de resina. A fibra selecionada deve ser a mais larga possível para melhor reforço. Para confecção de núcleos, geralmente utilizam-se fitas com largura de $1 \mathrm{~mm}, 2 \mathrm{~mm}$ ou $3 \mathrm{~mm}$, dependendo do diâmetro do conduto. Os autores descreveram a confecção de um núcleo de preenchimento com pinos pré-fabricados de fibras de vidro em um incisivo central. Além do pino de fibras de vidro principal (Luscent Anchor), cimentaram-se no conduto vários pinos acessórios mais finos (sistema Fibrelux) para preencher o conduto com um maior volume de fibras e diminuir a quantidade de cimento resinoso. Construiu-se a porção coronária do núcleo com resina composta híbrida.

$\mathrm{KAKAR}^{63}$, em 2001, empregou fibras de polietileno Ribbond para confecção de um núcleo de preenchimento. Um paciente jovem fraturou o incisivo central superior no terço cervical, com exposição pulpar. Após tratamento endodôntico, desobturou-se o conduto até $12 \mathrm{~mm}$ a partir da borda incisal do remanescente dentário. Utilizaram-se duas fitas de Ribbond ( $3 \mathrm{~mm}$ de largura), uma com $30 \mathrm{~mm}$ de comprimento e outra com $28 \mathrm{~mm}$. O conduto e o remanescente dentário foram condicionados com ácido fosfórico e o sistema adesivo foi aplicado. Cimento resinoso dual foi inserido no conduto com a ponta agulha da seringa Centrix e aplicado sobre as fitas, previamente dobradas ao meio e impregnadas com adesivo. As fitas foram levadas ao conduto com condensador endodôntico. O conduto foi preenchido com Ribbond e quatro pontas da fita (com $3 \mathrm{~mm}$ cada) ficaram sobressaindo do conduto. As pontas foram cobertas com cimento para modelar o núcleo. O núcleo foi preparado para receber uma coroa total. O autor lembrou que a confecção de núcleos metálicos fundidos envolve muitos passos laboratoriais que podem conduzir a erros. Núcleos fundidos, quando muito justos, podem causar efeito de cunha na raiz, e se muito frouxos deslocam-se facilmente. Os núcleos fibroresinosos permitem eliminar os passos laboratoriais. Além disso, o núcleo é adesivo, criando um sistema do tipo monobloco com o remanescente dentário, o que favorece a transmissão de forças oclusais sobre a raiz. As fitas de Ribbond reforçadas com resina são resistentes e não interferem com a cor de restaurações sem metal.

BOTTINO et al. ${ }^{14}$, em 2001, afirmaram que o objetivo da incorporação de fibras em resinas é aumentar sua resistência. Os produtos mais recentes melhoraram suas propriedades mecânicas pela incorporação de maior quantidade de 
fibras (até $40-45 \%$ em volume de fibras, como o FibreKor). As fibras utilizadas com maior sucesso são as de vidro e as de polietileno. Fibras de vidro compõem-se de silício, alumínio e óxidos de magnésio, e possuem melhores propriedades de flexão que as fibras de polietileno. Fibras de polietileno possuem alta resistência à tração, mas baixa resistência à compressão. As fibras odontológicas podem possuir diferentes arranjos: (1) unidirecional, (2) entrelaçada ou malha e (3) trançada. Produtos unidirecionais são formados por fibras paralelas entre si e possuem alta resistência flexural (importante para próteses fixas), mas durante a manipulação as fibras são espaçadas. Produtos trançados possuem feixes de fibras emaranhadas como tranças de cabelo. Padrões entrelaçados ou malha incluem, além de fibras paralelas, outras que correm perpendicularmente. Materiais reforçados com fibras são anisotrópicos: quanto mais paralela a direção da carga aplicada em relação à orientação da fibra, mais elevada a resistência do material. A resistência melhora com: (1) maior volume de fibras (mas se em quantidade excessiva não são totalmente impregnadas pela resina); (2) distribuição uniforme de fibras na estrutura; (3) melhor incorporação da resina nas fibras. Alguns produtos são fornecidos pré-impregnados, proporcionando menor número de passos, melhores propriedades mecânicas, impregnação homogênea da resina e boa consistência de manipulação; porém, a resina não pode ser selecionada. Quanto aos sistemas não impregnados, o tempo de trabalho é maior, a impregnação completa das fibras é difícil e pode haver contaminação da fibra; contudo, o operador pode selecionar a resina. Na Figura 2.1 e na Figura 2.2 estão resumidas as características das fibras em forma de fita mais conhecidas.

\begin{tabular}{c|c|c|c|c|c} 
Produto & Fabricante & $\begin{array}{c}\text { Tipo de } \\
\text { fibra }\end{array}$ & $\begin{array}{c}\text { Arquitetura } \\
\text { da fibra }\end{array}$ & $\begin{array}{c}\text { Resistência } \\
\text { flexural }\end{array}$ & $\begin{array}{c}\text { Facilidade de } \\
\text { adaptação }\end{array}$ \\
\hline GLASSPAN & GlasSpan & Vidro & Trançada & Média & Alta \\
\hline $\begin{array}{c}\text { FIBER- } \\
\text { SPLINT }\end{array}$ & Polydentia & Vidro & Entrelaçada & Muito baixa & Média \\
\hline RIBBOND & Ribbond & Polietileno & Entrelaçada & Baixa & Muito alta \\
\hline CONNECT & Kerr & Polietileno & Trançada & Baixa & Alta \\
\hline DVA FIBERS & $\begin{array}{c}\text { Dental } \\
\text { Ventures }\end{array}$ & Polietileno & Unidirecional & Baixa & Alta
\end{tabular}

FIGURA 2.1 - Quadro comparativo das características mais relevantes dos produtos que requerem impregnação (BOTTINO et al., 2001). 


\begin{tabular}{|c|c|c|c|c|c|c|}
\hline Produto & Fabricante & $\begin{array}{l}\text { Tipo de } \\
\text { fibra }\end{array}$ & $\begin{array}{l}\text { Arquitetura } \\
\text { da fibra }\end{array}$ & $\begin{array}{l}\text { Resistência } \\
\text { flexural }\end{array}$ & $\begin{array}{c}\text { Cores } \\
\text { disponíveis }\end{array}$ & $\begin{array}{c}\text { Facilidade } \\
\text { de } \\
\text { adaptação }\end{array}$ \\
\hline \multirow{2}{*}{ SPLINT-IT! } & \multirow{2}{*}{$\begin{array}{l}\text { Jeneric/ } \\
\text { Pentron }\end{array}$} & \multirow{2}{*}{ Vidro } & Unidirecional & Alta & 1 & Média \\
\hline & & & Entrelaçada & Média & 1 & Alta \\
\hline SPLINT-IT! & $\begin{array}{l}\text { Jeneric/ } \\
\text { Pentron }\end{array}$ & Polietileno & Unidirecional & Alta & 1 & Média \\
\hline \multirow[b]{2}{*}{ VECTRIS } & \multirow[b]{2}{*}{ Ivoclar } & \multirow[b]{2}{*}{ Vidro } & Unidirecional & Alta & 1 & \multirow{2}{*}{$\begin{array}{c}\text { Realizada } \\
\text { por } \\
\text { máquina }\end{array}$} \\
\hline & & & Malha & Média & 1 & \\
\hline FIBREKOR & $\begin{array}{l}\text { Jeneric / } \\
\text { Pentron }\end{array}$ & Vidro & Unidirecional & Alta & 5 & Média \\
\hline
\end{tabular}

FIGURA 2.2 - Quadro comparativo das características mais relevantes dos produtos préimpregnados (BOTTINO et al., 2001).

Quanto às características clínicas das fibras de vidro, observaram que o GlasSpan se adapta facilmente aos dentes, é acondicionado em tubos de vidro para evitar contaminação, possui boa adesividade e tem menor índice de falhas em relação a ferulizações com fios ortodônticos. Ressaltaram que a fibra de vidro Fiber-Splint é muito larga para uso clínico e abre-se facilmente quando manipulada.

A reconstrução de dentes endodonticamente tratados com pinos fibroresinosos foi descrita por TERRY; TRIOLO ${ }^{130}$, em 2001. Os materiais utilizados, em conjunto, simulam as propriedades físicas do dente natural, criando um complexo restaurador que devolve função e estética. Tais materiais são: fibras de polietileno, agentes de união hidrofílicos, cimento resinoso dual e resina composta. As fibras hidrofóbicas são tratadas com plasma de gás frio, tornando-se hidrofílicas. Isto permite molhamento completo pelo adesivo, pois cria um baixo ângulo de contato; o aumento da área de superfície e dos grupos funcionais $\mathrm{O}-\mathrm{C}=\mathrm{O}$ permite adesão química entre fibras e resinas. O reforço com fibras aumenta a resistência à tração. A arquitetura entrelaçada do Ribbond resiste melhor ao deslocamento sob tração que as demais fitas, minimizando a propagação de fraturas por coalescência de microtrincas dentro da matriz resinosa. As fibras auxiliam a redirecionar o estresse para o longo eixo da raiz. As vantagens são: flexibilidade das fibras; consulta única; fratura radicular improvável; preparo do conduto desnecessário; melhor retenção pelo aumento da superfície retentiva, resultante das irregularidades do conduto; ótima estética. A principal desvantagem é a alta sensibilidade do protocolo adesivo. Este pinos têm potencial para sucesso a longo prazo, porém mais pesquisas são necessárias para demonstrar sua efetividade. 
Segundo STEWARDSON ${ }^{127}$, em 2001, as principais vantagens dos pinos não-metálicos são: (1) reduzido número de fraturas radiculares (geralmente favoráveis quando ocorrem); (2) estética melhorada; (3) fácil remoção (exceto para pinos cerâmicos); (4) maior biocompatibilidade (ausência de corrosão e citotoxicidade); (5) formação de um complexo biomecânico único pela adesão entre estrutura dentária, agente cimentante e pino, reforçando a raiz. $\mathrm{O}$ autor classificou os pinos não-metálicos em pinos de materiais compósitos e pinos cerâmicos. Os pinos de compósitos, que devido à similaridade de seu módulo de elasticidade com o da dentina, minimizam fraturas radiculares, podem classificar-se em: (1) pinos de fibras de carbono (Composipost, Endopost), que em versões atuais podem ser encontrados radiopacos; (2) pinos de fibras de vidro, geralmente quartzo ou sílica-zircônia em matriz resinosa (Fibrekor, Aestheti-Post, Aestheti-Plus, Snowpost), com propriedades físicas similares às dos pinos de fibras de carbono; (3) pinos fototransmissores (Lightpost, Luscent Anchors), compostos por fibras de vidro translúcidas, que visam facilitar a polimerização de cimentos duais ou fotopolimerizáveis; (4) pinos de fibras de polietileno. Pinos cerâmicos (Cosmopost, Cerapost) são mais indicados com coroas de porcelana pura pela excelente estética, e possuem alta resistência e dureza, bem como biocompatibilidade. Sobre o pino FibreKor observou que sua matriz (até $29 \%$ em peso) é uma resina composta com carga inorgânica envolvendo as fibras de vidro (42\% em peso), que são arranjadas longitudinalmente. São fornecidos com brocas de diâmetros correspondentes aos três tamanhos de pinos (1mm, 1,25mm e 1,5mm); também estão disponíveis tamanhos intermediários (1,125mm e 1,375mm).

RAYGOT; CHAI; JAMESON ${ }^{106}$, em 2001, estudaram o modo de fratura inicial e a resistência à fratura de incisivos centrais superiores despolpados e restaurados com núcleos metálicos fundidos, pinos pré-fabricados de aço inoxidável ou de fibras de carbono. Quando utilizados pinos pré-fabricados, confeccionou-se a porção coronária com resina composta. Cimentaram-se coroas totais metálicas com fosfato de zinco sobre os núcleos. Após armazenamento dos espécimes por 24 horas em água destilada, estes foram submetidos à carga compressiva em ângulo de $130^{\circ}$ com o longo eixo do dente, à velocidade de $25,4 \mathrm{~mm} / \mathrm{min}$. A carga foi programada para cessar ao primeiro sinal de fratura, permitindo melhor análise do modo de fratura que em estudos nos quais o espécime é totalmente destruído e falhas secundárias são geradas. Para detectar o modo inicial de falha, os dentes foram imersos em tinta preta por 12 horas e seccionados no sentido mésio-distal. A resistência à fratura foi similar entre os três grupos: $38,13 \mathrm{kgf}$ para núcleos metálicos fundidos, 31,3kgf para pinos de 
fibras de carbono e 31,1kgf para pinos de aço. Em todos os espécimes, houve falhas adesivas entre pino e estrutura dentária, bem como fratura dentária. Nos três grupos, 70 a $80 \%$ dos dentes mostraram fraturas acima do nível ósseo simulado. Não ocorreram falhas coesivas de materiais restauradores.

BAE et al. ${ }^{7}$, em 2001, avaliaram a resistência flexural e o módulo de elasticidade de várias combinações de resinas compostas reforçadas por fibras: 1) resina Sculpture e fibra de vidro Fibrekor; 2) resina Targis Dentin e fibra de vidro Vectris; 3) resina Aelitefil com fibra de polietileno Ribbond, fibra de poliaramida Fibreflex ou fibra de vidro GlasSpan. Com Ribbond e GlasSpan utilizaram ainda o cimento resinoso C \& B Cement para verificar se este pode ser utilizado para confecção de núcleos de preenchimento. No caso do Ribbond, GlasSpan e Fibrekor, posicionou-se a fibra em uma matriz de aço inoxidável de $25 \mathrm{~mm} \times 2 \mathrm{~mm} \times 2 \mathrm{~mm}$; com o Fibreflex, utilizou-se apenas um terço da fibra. Impregnaram-se as fibras com adesivo, seguindo-se a compactação e polimerização da resina na matriz. Confeccionaram-se ainda espécimes não reforçados por fibras. Armazenaram-se cinco espécimes de cada grupo em água a $37^{\circ} \mathrm{C}$ por 24 horas e executaram-se os testes na máquina de ensaios à velocidade de $1 \mathrm{~mm} / \mathrm{min}$, com os espécimes imersos na água. Analisou-se a superfície fraturada com microscopia eletrônica de varredura, que mostrou boa impregnação pelo adesivo para o Ribbond, mas pequenas falhas na interface fibraresina composta. Nenhuma das fibras de vidro mostrou defeitos nesta interface ou dificuldade de impregnação pela resina. Com Fibreflex, a interface era adequada, mas observaram-se pequenas fraturas entre fibra e sistema adesivo. Com o reforço de $C \&$ B Cement por GlasSpan ou Ribbond, a resistência flexural ou a capacidade adesiva da fibra não foram significativamente diferentes em relação à resina composta Aelitefil reforçada por fibras, mostrando seu potencial para confecção de núcleos de preenchimento. Todas as fibras (à exceção do Vectris) aumentaram a resistência flexural das resinas compostas. O GlasSpan, o FibreFlex e o Fibrekor foram efetivos em aumentar o módulo de elasticidade.

STRUB; PONTIUS; KOUTAYAS ${ }^{129}$, em 2001, avaliaram a taxa de sobrevivência e resistência à fratura de incisivos centrais superiores despolpados e restaurados com quatro tipos de núcleos: (1) pino metálico contendo paládio e porção coronária em liga metálica preciosa; (2) pino cerâmico com porção coronária em cerâmica pré-fabricada Procera (coping Ceracap); (3) pino experimental resinosocerâmico fresado em máquina Celay, também com coping Ceracap na porção 
coronária; (4) pino cerâmico com porção coronária em cerâmica fundida. Para cimentação, utilizou-se fosfato de zinco no grupo 1 e cimento resinoso nos demais grupos. Cimentaram-se os copings cerâmicos sobre os pinos (grupos 2 e 3 ) com cimento resinoso. As taxas de sobrevivência após exposição a 1,2 milhões de ciclos em boca artificial (equivalendo a cinco anos em ambiente oral) para os diferentes grupos foram: (1) 90\%; (2) 80\%; (3) 60\%; e (4) 100\%. Submeteram-se os espécimes remanescentes a cargas compressivas em ângulo de $135^{\circ} \mathrm{com}$ seu longo eixo, à velocidade de $0,5 \mathrm{~mm} / \mathrm{min}$. As médias de resistência à fratura para os quatro grupos foram: (1) 129,5kgf; (2) 152,3kgf; (3) 116,9kgf; e (4) 47,2kgf. Houve diferenças significativas entre todos os grupos, com exceção dos grupos 1 e 2 e dos grupos 1 e 3. Nenhum núcleo do grupo 4 fraturou no teste de fadiga; a resistência deste grupo foi menor que a dos demais (possivelmente devido a alterações internas da zircônia durante a fundição), mas manteve-se acima do nível clínico necessário.

CORMIER; BURNS; MOON ${ }^{22}$, em 2001, avaliaram seis sistemas de núcleos (núcleos metálicos fundidos, pino de aço inoxidável ParaPost $\mathrm{XH}$, pino de fibras de carbono C-Post, pino de fibras de carbono-quartzo Aestheti-Post, pino de fibras de vidro FibreKor e pinos cerâmicos CosmoPost) em quatro estágios clínicos da restauração para determinar resistência à fratura e modo de falha em cada estágio. Os estágios analisados foram (10 espécimes para cada estágio): 1) somente o pino, seccionado em $10 \mathrm{~mm}$ de comprimento e submetido a carga em ângulo reto, no ponto médio (teste de flexão dos três pontos); 2) somente o pino, cimentado no conduto; 3 ) pino cimentado e confecção da porção coronária do núcleo; 4) cimentação de coroa total sobre o núcleo. Para os estágios 2 a 4, removeu-se a coroa de 180 pré-molares inferiores despolpados e fixaram-se os espécimes em blocos de resina acrílica. Prepararam-se os condutos até $8 \mathrm{~mm}$ de profundidade. Cimentaram-se os pinos com cimento resinoso e confeccionou-se a porção coronária dos núcleos com resina composta. No estágio 4, cimentou-se com ionômero de vidro híbrido uma coroa total metálica sobre o núcleo. Nos estágios 2 a 4, armazenaram-se os espécimes em umidificador por 24 horas e depois em água a $37^{\circ} \mathrm{C}$ por 7 dias. Aplicou-se uma carga estática na máquina de ensaios em ângulo de $90^{\circ}$ com o longo eixo da raiz. Considerou-se a fratura desfavorável quando os dentes exibiram fraturas verticais ou oblíquas estendendo-se abaixo da borda do bloco de resina acrílica. Os valores de resistência para cada pino foram significativamente diferentes em cada estágio, mas de modo geral a seqüência dos resultados por tipo de pino foi similar de um estágio para outro. No estágio 1, os pinos Para-Post e os núcleos fundidos exibiram 
dobramento e deformação plástica gradual. Pinos de fibra fraturaram em "galho verde". Pinos Para-Post mostraram a maior resistência e grande quantidade de fraturas desfavoráveis nos quatro estágios. Pinos FibreKor apresentaram menor resistência que os demais nos estágios 2 a 4, não causaram fraturas dentárias nos estágios 2 e 3 e no estágio 4 o número de fraturas desfavoráveis foi similar ao dos outros pinos. Em um grupo intermediário quanto à resistência, situaram-se C-Post, Cosmopost e AesthetiPost (ordem decrescente), apresentando número moderado de fraturas desfavoráveis. O CosmoPost exibiu número significativo de fraturas em todos os estágios, devido à friabilidade. A resistência do núcleo metálico foi sempre alta, mas variável em cada estágio, sendo que com este núcleo nenhum dente fraturou no estágio 2, 90\% dos dentes fraturaram desfavoravelmente no estágio 3 , e todos fraturaram desfavoravelmente no estágio 4 . No estágio 4 (prótese concluída), não houve diferença na resistência entre os pinos testados, exceto para o FibreKor, que continou a apresentar resultados menores que os demais pinos. Concluiu-se que pinos de fibras possuem vantagem quanto à preservação dentária sobre pinos metálicos pré-fabricados e núcleos metálicos fundidos (pequeno número de fraturas desfavoráveis em relação aos sistemas metálicos).

FUSS et al., em $2001^{42}$, avaliaram a influência dos procedimentos operatórios na etiologia das fraturas radiculares verticais, ressaltando que esta é uma complicação que geralmente leva à extração dentária. Em cinco clínicas públicas, armazenaram-se por sete anos 154 dentes extraídos e com fratura vertical de raiz para análise posterior. Obtiveram-se as radiografias periapicais pré-extração, bem como os registros dos achados clínicos e procedimentos operatórios executados. Observou-se a presença de um pino em 95 dentes $(61,7 \%)$, dos quais 82 possuíam coroas totais. A maioria dos pinos $(67,3 \%)$ era do tipo Dentatus parafusado e núcleos metálicos fundidos cônicos $(14,7 \%)$ e 66 pinos estendiam-se somente até o terço cervical da raiz. Uma coroa total foi observada em 118 dentes (76,6\%), e 65 destes (55\%) foram extraídos entre um a cinco anos após a restauração final. Em 24 dentes com coroa total, a extração ocorreu antes de um ano após a restauração. Concluiu-se que: 1) a utilização de coroas totais e pinos intra-radiculares não previne fraturas verticais da raiz, pois estas ocorreram em estágios precoces após o tratamento; 2) o tratamento endodôntico e a presença de pinos foram os principais fatores etiológicos de fraturas verticais; 2) são recomendadas rechamadas freqüentes para diagnóstico precoce de fraturas, especialmente em áreas susceptíveis (pré-molares e raízes mesiais de molares inferiores). 
MANNOCCI; SHERRIFF; WATSON ${ }^{77}$, em 2001, submeteram vários pinos ao teste de flexão dos três pontos: Composipost e Carbotech (fibras de carbono), Aestheti-Plus (fibras de quartzo), Light-Post (fibras de vidro) e Snowpost (fibras de sílica), após armazenamento por um ano sob diferentes condições: 1) a seco e em temperatura ambiente; 2) em água à $37^{\circ} \mathrm{C} ; 3$ ) selados (e não cimentados) no interior dos canais de dentes bovinos endodonticamente tratados, seccionados na junção cemento-esmalte, com câmara pulpar restaurada com resina composta e armazenados em água à $37^{\circ} \mathrm{C}$. Dois pinos de cada grupo foram analisados sob microscopia confocal antes e após a armazenagem, e também durante os testes, através de uma vídeo-câmera. A carga foi aplicada à velocidade de $0,5 \mathrm{~mm} / \mathrm{min}$. Pinos armazenados em água apresentaram menor resistência à flexão que pinos armazenados a seco. Pinos selados nos condutos mostraram resistência à flexão similar à de pinos armazenados a seco. Sob todas as condições, os pinos Carbotech mostraram maior resistência à flexão que pinos Composipost e Snowpost; os pinos Aestheti-Plus foram mais resistentes que pinos Snowpost. Todos os pinos mostraram muitas áreas com vazios na estrutura, mas o Composipost mostrou mais vazios que os demais e uma pior ligação entre as fibras e a matriz. Concluiu-se que os pinos não devem entrar em contato com fluidos orais e que durante um ano armazenados em dentes bovinos foram adequadamente protegidos do contato com a água.

BUTZ et al. $^{18}$, em 2001, compararam taxas de sobrevivência e resistência à fratura de incisivos centrais superiores despolpados e restaurados com diferentes tipos de pinos após exposição a cargas cíclicas: (1) pinos de titânio com porção coronária em resina composta; (2) pinos cerâmicos com porção coronária em resina composta; (3) pinos cerâmicos com porção coronária em cerâmica termoprensada (Empress); (4) núcleos metálicos fundidos em ouro. Cimentaram-se os pinos com cimento resinoso e sobre os núcleos cimentaram-se coroas metálicas com ionômero de vidro. Foram mantidos $2 \mathrm{~mm}$ de estrutura dentária para obtenção do efeito férula. Os espécimes foram expostos a 1,2 milhões de ciclos em simulador de mastigação, com termociclagem simultânea. Os espécimes sobreviventes foram submetidos à carga compressiva em ângulo de $130^{\circ}$ com o longo eixo do dente, à velocidade de 1,5mm/min. Os grupos 1,3 e 4 mostraram taxas de sobrevivência e resistência à fratura similares. As taxas de sobrevivência e médias de resistência para cada grupo foram, respectivamente: (1) $94 \%$ e 43,3kgf; (2) $63 \%$ e $20,5 \mathrm{kgf}$; (3) $100 \%$ e 38,5kgf; (4) 94\% e 43,4kgf. Concluiu-se que pinos de zircônia associados à resina composta não são indicados para uso clínico, devido à taxa de sobrevivência e 
resistência à fratura baixas (diferença significativa em relação aos demais grupos). Os grupos 1 e 4 apresentaram padrão similar de fraturas (geralmente oblíquas, no terço médio ou apical da raiz); nos grupos 2 e 3 houve menos fraturas desfavoráveis da raiz.

$\mathrm{VICHI}$ et al. ${ }^{137}$, em 2002, avaliaram a efetividade de três sistemas adesivos de um frasco (grupos 3, 4 e 5) e de dois sistemas adesivos de três passos (grupos 1 e 2) quanto à formação da camada híbrida, de tags de resina e de ramificações laterais de adesivo quando usados para cimentação de pinos de fibras. Distribuíram-se 50 dentes tratados endodonticamente, a serem extraídos por razões endodônticas ou periodontais, em cinco grupos (10 espécimes cada), onde utilizaramse as seguintes combinações de sistema adesivo e cimento resinoso: 1) All Bond 2 com C \& B Cement; 2) Scotchbond Multipurpose Plus com Opal Luting Composite; 3) Scotchbond 1 com RelyX ARC; 4) One-Step com C \& B Cement; 5) All Bond Experimental com Post Cement HI-X. Utilizaram-se todos os materiais como recomendado pelos fabricantes. Cimentaram-se 50 pinos de fibras de quartzo Aestheti-Plus em condutos preparados até $9 \mathrm{~mm}$ de profundidade. Uma semana depois, as raízes foram extraídas e observadas em microscópio eletrônico de varredura. Ocorreu formação da camada híbrida, tags de resina e ramificações laterais com todos os adesivos, mas com melhor qualidade nos grupos 1 e 2 . A morfologia e formação da camada híbrida e dos tags de resina foi mais facilmente detectável e uniforme nos terços cervical e médio dos canais que no terço apical. Não houve diferença significativa entre os três adesivos de um frasco nas áreas avaliadas. Concluiu-se que sistemas adesivos de três passos proporcionam melhor embricamento micromecânico entre adesivo e dentina que sistemas de um frasco, especialmente no terço apical.

ESKITAŞCIOĞLU; BELLI; KALKAN ${ }^{29}$, em 2002, compararam núcleos confeccionados de fibras de polietileno Ribbond e cimento resinoso dual Variolink 2 com núcleos metálicos fundidos, utilizando teste de resistência à fratura convencional e método do elemento finito (para análise do efeito da rigidez do núcleo na distribuição do estresse). Para o teste de resistência à fratura, dois grupos de incisivos centrais superiores (10 dentes em cada grupo) tiveram a coroa removida $1 \mathrm{~mm}$ acima da junção cemento-esmalte e foram endodonticamente tratados. Para os núcleos com Ribbond, o remanescente dentário e o canal foram condicionados com ácido fosfórico e então foi aplicado o adesivo; duas fitas de Ribbond com $2 \mathrm{~mm}$ de largura, medindo o 
dobro da profundidade do conduto (que era de $8 \mathrm{~mm}$ ), adicionando-se 16 a $20 \mathrm{~mm}$, foram impregnadas com adesivo; as fitas foram dobradas em forma de letra " $V$ " e em sua parte interna aplicou-se o cimento. A primeira fita de Ribbond foi inserida no conduto e após esta outra fita em orientação perpendicular à primeira. Uma porção adicional de cimento foi aplicada e polimerizada entre as fitas que emergiam do conduto. Cimentaram-se os núcleos metálicos com fosfato de zinco. Os núcleos não foram recobertos com coroas totais. Os dentes foram fixados em blocos de resina acrílica. Armazenaram-se os espécimes em água por 24 horas antes do teste. Não houve diferença significativa na resistência entre os dois sistemas: $37,7 \mathrm{kgf}$ para núcleos metálicos fundidos e 33,4kgf para núcleos de fibras de polietileno. Para análise pelo método do elemento finito construíram-se modelos tridimensionais de incisivos centrais superiores restaurados com ambos os sistemas e uma carga de $200 \mathrm{~N}$ simulou as forças mastigatórias. O método mostrou uma maior concentração de estresse ao longo dos núcleos metálicos fundidos, sendo baixa a transmissão de estresse para o dente e estruturas de suporte. Com núcleos de fibras, o estresse foi mais transferido para o dente e estruturas de suporte (especialmente na região cervical), acumulando-se menos no próprio núcleo. Porém, sete das 10 raízes com núcleos metálicos fundidos fraturaram (geralmente no terço cervical), possivelmente devido ao deslocamento do pino (que ocorreu em todas as raízes) por falta de adesão. Com núcleos de Ribbond, somente duas raízes fraturaram; em sete delas fraturou a porção coronária do núcleo e em uma delas o pino deslocou.

PEST et al. ${ }^{99}$, em 2002, avaliaram a adesão entre cimentos, dentina radicular e pinos de fibras e examinaram a interface entre estes materiais sob microscopia eletrônica de varredura (MEV). Compararam ainda o desempenho entre cimentos resinosos tradicionais com o de resinas compostas autopolimerizáveis e fotopolimerizáveis usadas como agentes cimentantes. Executaram-se dois testes de extrusão (push-out) para testar a resistência adesiva dos cimentos com a dentina ou com os pinos. Utilizaram-se 50 dentes unirradiculares tratados endodonticamente para o teste de extrusão que avaliou a adesão entre cimento e dentina. Removeu-se a coroa e prepararam-se os condutos até $8 \mathrm{~mm}$ de profundidade com broca diamantada cilíndrica, para obtenção de espessura uniforme de cimento em todo o canal. Após a inserção do cimento, seccionaram-se as raízes transversalmente, obtendo-se quatro fatias com $2 \mathrm{~mm}$ de espessura. Os materiais usados no primeiro teste foram: 1 ) adesivo All Bond 2 / cimento resinoso C\&B Cement; 2) adesivo ED Primer / cimento resinoso Panavia F; 3) adesivo Clearfil Liner Bond 2V / resina composta Clearfil Core; 
4) Clearfil Linerbond $2 \mathrm{~V} /$ resina composta Clearfil Photocore; 5) All Bond 2 / resina composta Ti-Core. Para o segundo teste, que avaliou adesão entre cimento e pino, prepararam-se 60 discos plásticos com $3 \mathrm{~mm}$ de espessura, inserindo o pino no centro e injetando cimento em torno do pino com pontas metálicas descartáveis. Os materiais testados foram: 1) C\&B Cement / Endocomposipost (fibras de carbono); 2) Panavia F / Tech 2000 (fibras de carbono); 3) Clearfil Liner Bond 2V / Clearfil Core / Tech 2000; 4) Clearfil Liner Bond 2V / Clearfil Core / Tech 21 Xop (fibras de vidro); 5) Clearfil Liner Bond 2V / Clearfil Photocore / Luscent Anchor (fibras de vidro). Armazenaram-se os espécimes em água destilada por 24 horas antes dos testes de extrusão, executados à velocidade de $0,5 \mathrm{~mm} / \mathrm{min}$. Analisaram-se ainda as diversas combinações de pinos $\mathrm{e}$ cimentos sob MEV, utilizando-se 30 dentes unirradiculares endodonticamente tratados. Após secção das coroas, os pinos foram cimentados. Inseriram-se os cimentos resinosos no canal com os próprios pinos e as resinas compostas com pontas metálicas descartáveis. Seccionaram-se os espécimes longitudinalmente, sendo que metade do espécime foi coberta com película de ouro e a outra metade tratada para remover componentes minerais e orgânicos da dentina (para análise da camada híbrida e tags de resina). Em ambos os testes de extrusão, todos os espécimes mostraram alta resistência adesiva (26-30MPa); os valores obtidos associando Tech 2000 com Panavia F e Tech 21 com Liner Bond 2V foram os mais altos. Houve melhor desempenho com resinas compostas que com cimentos resinosos, o que foi confirmado pela MEV. Com ED Primer, a camada híbrida não era homogênea em todo o canal, e os tags de resina, quando presentes, eram irregulares e de comprimentos diferentes. Com adesivo auto-condicionante Clearfil Liner Bond 2V, houve tanto áreas sem tags quanto áreas com muitos tags. O All Bond 2 gerou tags numerosos e longos em todo o canal. De modo geral, houve mais bolhas na camada de cimentos que com resinas compostas autopolimerizáveis. Obtiveram-se os melhores resultados com combinação de pino translúcido e resina composta fotopolimerizável, não sendo observadas bolhas neste grupo. Concluiu-se que a cimentação de pinos com resinas compostas é uma alternativa comparável e em alguns casos superior aos cimentos resinosos, pois são fáceis de manipular, pode-se usá-las também para restaurar a porção coronária e o tempo de trabalho é longo. Porém, há dúvidas sobre a polimerização total de resinas na região apical do conduto.

A influência de sete sistemas adesivos nas propriedades de flexão de fibras de polietileno foram avaliadas por ELLAKWA et al. ${ }^{28}$, em 2002. Prepararam-se nove grupos (grupos $\mathrm{A}$ até $\mathrm{I}$ ) de barras utilizando resina composta reforçada com 
fibras de polietileno Connect, inseridas na base da matriz. No grupo I reforçou-se com fibras não impregnadas com adesivo. $\mathrm{O}$ grupo $\mathrm{J}$ foi preparado apenas com resina composta. Nas fibras dos grupos A até G utilizaram-se diferentes adesivos; nos grupos $\mathrm{G}$ e $\mathrm{H}$ foi usado o mesmo adesivo, mas no grupo $\mathrm{H}$ as fibras foram silanizadas antes da aplicação do adesivo. Armazenaram-se os espécimes em água destilada por 24 horas a $37^{\circ} \mathrm{C}$ antes de medir resistência à flexão e módulo de flexão (módulo de elasticidade), à velocidade de $1 \mathrm{~mm} / \mathrm{min}$. A microscopia eletrônica de varredura (MEV) mostrou total justaposição entre fibras impregnadas e resina; com fibras não impregnadas, havia áreas de separação (gaps) na interface fibra-resina. Houve diferenças significativas na resistência à flexão entre os grupos impregnados pelos diversos adesivos; a maior média foi vista com adesivos com maior carga de partículas inorgânicas, provavelmente pela menor contração de polimerização (menos falhas adesivas). Nos grupos reforçados, os fragmentos mantiveram-se unidos entre si, mas no grupo sem reforço, que obteve a menor resistência à flexão, houve falhas catastróficas. A pré-silanização antes da impregnação com adesivo reduziu significativamente a resistência à flexão e o módulo de flexão, possivelmente devido à influência negativa do silano sobre o tratamento superficial com plasma. Com fibras não impregnadas houve baixa resistência à flexão e baixo módulo de flexão. Ressaltaram que a adesão adequada das fibras à matriz resinosa otimiza a resistência, pois aumenta o contato entre matriz e fibras e possibilita transferir o estresse da matriz para as fibras. Concluiu-se que a impregnação com adesivo afetou significativamente a resistência à flexão das fibras. Ainda foi investigada a influência da imersão por 24 horas de fibras de polietileno em componentes comuns de adesivos, como acetona e etanol (solventes) ou HEMA (hidroxietilmetacrilato). A imersão em acetona dissolveu quase toda a fibra; a imersão em etanol causou fissuras superficiais; e o HEMA não afetou a fibra. Adesivos com acetona ou etanol reduzem a adesão ou degradam as fibras ao longo do tempo, como foi confirmado pela análise da composição dos adesivos testados.

O efeito de um pino metálico e de três pinos estéticos na resistência à fratura e padrões de fratura de dentes endodonticamente tratados foi estudado por AKKAYAN; GÜLMEZ 4 , em 2002. Após remoção das coroas, 40 caninos superiores foram restaurados com pinos de titânio, de dióxido de zircônia, de fibras de quartzo ou de fibras de vidro, denominados como grupos 1, 2, 3 e 4, respectivamente. Cimentaram-se os pinos com cimento resinoso. A porção coronária do núcleo foi construída com resina composta e coroas metálicas foram cimentadas sobre os 
núcleos com ionômero de vidro. Os espécimes foram fixados em blocos de resina acrílica e submetidos à compressão em máquina de ensaios, em ângulo de $130^{\circ} \mathrm{com}$ o longo eixo do dente e à velocidade de $1 \mathrm{~mm} / \mathrm{min}$. $O$ grupo 2 exibiu resistência significativamente maior que os demais (seguindo-se, em ordem decrescente, os grupos 4, 3 e 1). Pinos cerâmicos e de fibras de vidro mostraram resistência similar. Observaram-se fraturas passíveis de reparo em dentes restaurados com pinos de fibras de quartzo e fibras de vidro, e observaram-se fraturas não restauráveis com pinos de zircônia e de titânio. Os autores especularam que uma das principais causas deste padrão de fratura deve ser o alto módulo de elasticidade de pinos de titânio e zircônia em relação à dentina, enquanto pinos de fibras de quartzo e de fibras de vidro possuem módulos próximos ao da dentina.

HEYDECKE; PETERS ${ }^{53}$, em 2002, conduziram uma revisão da literatura para comparar o comportamento clínico e laboratorial de núcleos metálicos fundidos com o de pinos pré-fabricados metálicos ou de fibras de carbono. Após seleção inicial de 1773 artigos, estes foram submetidos a critérios de inclusão. Para estudos laboratoriais, os critérios foram: dentes unirradiculares, restauração com coroas totais e aplicação da carga em ângulo de 130 a 135\%; para estudos clínicos foram: acompanhamento por pelo menos três anos, dentes anteriores, restauração com coroas totais, descrição dos sistemas testados e informações sobre sobrevivência ou sucesso do estudo. Permaneceram dez artigos laboratoriais e seis clínicos. A comparação da resistência à fratura em estudos laboratoriais não revelou diferenças significativas entre núcleos fundidos e de preenchimento. Por falta de dados, uma análise global de sobrevivência não foi possível com estudos clínicos. A sobrevivência para núcleos metálicos fundidos em dois estudos variou de $87,2 \%$ a $88,1 \%$ e em um terceiro estudo alcançou $86,4 \%$ após 72 meses. A meta-análise dos estudos laboratoriais não encontrou diferenças no padrão de fratura entre núcleos fundidos ou de preenchimento: a maioria das fraturas ocorreu no terço médio ou apical da raiz. Somente com pinos de fibras de carbono a fratura geralmente ocorreu acima do suporte acrílico (fratura restaurável). Observaram que sendo comparáveis os resultados dos tratamentos, restaurações diretas reduzem tempo e custos para o paciente. Porém, estudos adicionais de acompanhamento de núcleos de preenchimento devem ser conduzidos, pois ainda são escassos.

HEYDECKE et al. ${ }^{54}$, em 2002, compararam a resistência à fratura de 64 incisivos centrais superiores tratados endodonticamente, com a coroa removida e 
divididos em quatro grupos iguais: 1) pinos de titânio e porção coronária em resina composta; 2) pinos de zircônia e porção coronária em resina composta; 3) pinos de zircônia e porção coronária de zircônia prensada (Empress); 4) núcleos metálicos fundidos em ouro. O término dos preparos foi em chanfrado, incluindo 1-2mm de férula em estrutura dentária. A cimentação dos núcleos foi com cimento resinoso. Coroas totais foram cimentadas com ionômero de vidro sobre os núcleos e os dentes foram expostos a 1,2 milhões de ciclos (força de 30N) para simular cinco anos de mastigação, aplicando-se termociclagem simultânea (entre $5^{\circ} \mathrm{C}$ e $55^{\circ} \mathrm{C}$ ). Após a ciclagem, registraram-se os seguintes padrões de sobrevivência: 93,8\% (grupo 1 e 2), $100 \%$ (grupo 3) e $87,5 \%$ (grupo 4). Submeteram-se os espécimes sobreviventes à compressão em máquina de ensaios à velocidade de $1,5 \mathrm{~mm} / \mathrm{min}$ e em ângulo de $130^{\circ}$ com o longo eixo dentário. Não houve diferença significativa na resistência à fratura entre os quatro grupos. Pinos metálicos causaram mais fraturas irreparáveis que os de zircônia. Concluiu-se que podem ser recomendados pinos de zircônia com porção coronária em cerâmica prensada como alternativa a núcleos metálicos fundidos, bem como pinos de titânio ou zircônia com porção coronária em resina composta, se houver preferência por procedimentos diretos.

OTTL et al. ${ }^{94}$, em 2002, avaliaram resistência à fratura e tipo de fratura de sete sistemas de pinos (diâmetro e comprimento similares): um pino metálico contendo paládio (Perma-dor $[A]$ ), três pinos metálicos sem paládio (Perma-dor twin [B], ER platinium-iridium [C], Endo-Core Pt-Ir [D]), dois cerâmicos (pino de zircônia Cerapost $[E]$ e pinos de óxido de alumínio obtidos em sistema Celay [F]), pino de fibras de carbono (Composipost [G]) e pino metálico com porção coronária em cerâmica (Perma-dor e cerâmica SMH $[\mathrm{H}]$ ). Confeccionou-se ainda um grupo controle sem pinos (I). As porções coronárias dos sistemas $A$ a $D$ foram construídas em liga metálica e para os pinos $E$ e $G$ em resina composta. Obtiveram-se raízes artificiais de resina composta com módulo de elasticidade similar ao da dentina, simulando incisivos centrais superiores. Cimentaram-se os pinos e as coroas totais metálicas com cimento resinoso. Após armazenados em água por 24 horas, os espécimes receberam carga compressiva em ângulo de $135^{\circ}$ com o longo eixo do dente, à velocidade de $0,5 \mathrm{~mm} / \mathrm{min}$. A resistência mais alta foi obtida com pinos de fibras de carbono (31,8kgf), possivelmente graças ao módulo de elasticidade próximo ao da dentina. A resistência de pinos metálicos sem paládio $(24,7 \mathrm{kgf}-30,6 \mathrm{kgf})$ não diferiu significativamente daquela do pino contendo paládio $(27,1 \mathrm{kgf})$. Os valores dos pinos cerâmicos diferiram significativamente entre si (30,6kgf para óxido de alumínio e 19,7kgf para zircônia). 
Para o pino metálico com porção coronária cerâmica, a resistência foi de $21,2 \mathrm{kgf}$. O grupo controle exibiu a menor resistência $(23,3 \mathrm{kgf})$, mas sem diferença significativa com os demais grupos. O padrão de fratura foi similar com todos os tipos de núcleos: geralmente, uma linha de fratura oblíqua iniciava-se no terço médio da face palatina radicular, estendendo-se até o terço apical na face oposta da raiz.

PONTIUS; HUTTER ${ }^{101}$, em 2002, avaliaram a taxa de sobrevivência e resistência à fratura de incisivos centrais superiores restaurados com diferentes tipos de núcleos: grupo A - pino pré-fabricado de liga de metal precioso, com porção coronária fundida em ouro; grupo B - pino de dióxido de zircônia, com casquetes cerâmicos pré-fabricados (Ceracap) cimentados sobre o pino com resina composta fotopolimerizável para construção da porção coronária; grupo C - pino experimental resinoso-cerâmico, obtido com sistema Celay. No grupo $A$, os pinos foram jateados com partículas de óxido de alumínio $(50 \mu \mathrm{m})$ e cimentados com fosfato de zinco. No grupo $B$, os pinos também foram jateados e cimentados com cimento resinoso autopolimerizável, também usado para cimentação no grupo C. Nos grupos A, B e C, a porção coronária do pino foi recoberta com um coping de cerâmica pura (Procera), cimentado com cimento resinoso. Estes três grupos foram comparados a um grupo sem pino (grupo D), no qual o conduto foi preparado e a cavidade de acesso foi selada com resina composta. Após a confecção, os espécimes eram fixados em blocos de resina autopolimerizável, mantendo-se $3 \mathrm{~mm}$ das raízes expostas. Submeteram-se os espécimes a cargas cíclicas (1.200.000 ciclos) em ambiente oral artificial (simulando 5 anos de uso), bem como termociclagem antes do teste final de estresse. Após obtidas as taxas de sobrevivência (grupo A - 90\%, grupo B - 80\%, grupo C - 60\% e grupo D - 100\%), os espécimes que não falharam com a carga dinâmica foram submetidos à carga estática de compressão na máquina de ensaios, em ângulo de $135^{\circ} \mathrm{com}$ o longo eixo da raiz, na velocidade de $0,5 \mathrm{~mm} / \mathrm{min}$. As médias obtidas com a compressão foram: 129,5kgf (grupo A), 152,3kgf (grupo B), 116,9kgf (grupo C) e 240,9kgf (grupo D). Houve diferenças significativas entre todos os grupos, exceto entre os grupos A e B, grupos A e C, e grupos B e C. Quando se considerou o número de ciclos até a falha, os espécimes do grupo $D$ demonstraram o melhor escore e os do grupo $\mathrm{C}$ o pior escore. Nesta situação, observaram-se diferenças significativas entre todos os grupos, exceto A e B. O maior número de fraturas verticais da raiz ocorreu com núcleos metálicos fundidos (grupo $A$ ), enquanto nos grupos $C$ e D ocorreu fratura horizontal na junção cemento-esmalte. No grupo $B$, houve fratura do coping e/ou da porção coronária, sem fraturas de raiz ou dos pinos. Consideraram-se 
as propriedades mecânicas do pino experimental (grupo C) inadequadas para restauração de dentes despolpados.

ALBUQUERQUE et al. ${ }^{1}$, em 2003, avaliaram o efeito de pinos intraradiculares de diferentes materiais e formas na distribuição do estresse em incisivos endodonticamente tratados, através do método do elemento finito. Consideraram-se todos os materiais homogêneos e isotrópicos, bem como a obtenção de uma adesão perfeita em todas as interfaces. Quatro modelos foram criados: 1) dente hígido; 2) dente restaurado com pino cônico $(2 \mathrm{~mm}$ de diâmetro cervical e $1 \mathrm{~mm}$ de diâmetro apical); 3) dente restaurado com pino cilíndrico (1,4mm de diâmetro); 3$)$ dente restaurado com pino de dois estágios (cervical com 1,8mm de diâmetro e apical com $1,2 \mathrm{~mm}$ de diâmetro). A porção coronária do núcleo foi confeccionada com resina composta reforçada por titânio e recoberta com coroa de porcelana. Nos três modelos, utilizaram-se pinos de aço inoxidável, de titânio e de fibras de carbono. Simulou-se a aplicação de uma carga estática de $10 \mathrm{~kg}$ na face palatina, próxima à borda incisal e em $45^{\circ}$ com o longo eixo dentário. Em relação aos dentes hígidos, o uso de pinos aumentou o nível de estresse, especialmente na região cervical da interface pinodentina da face palatina. Pinos de aço causaram o maior estresse, seguidos por pinos de titânio e finalmente por pinos de fibras de carbono. Não houve diferenças significativas na concentração do estresse relacionadas à forma do pino.

KAIZER $^{62}$, em 2003, avaliou a resistência à fratura de dentes despolpados reconstruídos com pinos de fibras de polietileno ou pinos dentários. Selecionou 60 caninos superiores seccionados na junção cemento-esmalte, tratados endodonticamente (condutos desobturados até $8 \mathrm{~mm}$ de profundidade) e fixados em blocos de resina acrílica. Distribuíram-se os espécimes em quatro grupos (15 dentes cada): 1) preparo convencional dos condutos e confecção de pinos de fibras de polietileno Ribbond; 2) preparo convencional dos condutos e pinos dentários; 3) condutos medianamente alargados e pinos dentários; 4) condutos amplamente alargados (espessura de paredes de $0,5 \mathrm{~mm}$ no terço cervical) e pinos dentários. Nos grupos 1 e 2, dilataram-se os condutos até a broca Largo $n^{\circ} 4$; nos grupos 3 e 4, os condutos sofreram desgastes seqüenciais padronizados, simulando raízes medianamente ou amplamente destruídas, respectivamente. Cimentaram-se os pinos com sistema adesivo Scotchbond Multi-Uso Plus e cimento resinoso Enforce. Construiu-se a porção coronária dos núcleos com resina composta reforçada com titânio Ti-Core. Após 24 horas de armazenamento em água destilada, submeteram-se 
os espécimes ao ensaio de resistência à fratura sob compressão na máquina de ensaios, em ângulo de $135^{\circ}$ com o longo eixo da raiz, à velocidade de $0,5 \mathrm{~mm} / \mathrm{min}$. Os valores de resistência à fratura foram (ordem decrescente): Grupo 3 - 58,67kgf; Grupo 2 - 53,30kgf; Grupo 4 - 47,91kgf; Grupo 1 - 45,46kgf. Houve diferença significativa apenas entre os grupos 1 e 3 . Em relação ao padrão de fratura, observou-se: ampla predominância de fratura da porção coronária do núcleo no grupo 1; padrão variado de fraturas (tanto radiculares como do pino e/ou porção coronária) nos grupos 2 e 3; fratura de $100 \%$ das raízes no grupo 4 . Concluiu-se que: 1 ) a resistência à fratura foi similar entre grupos reconstruídos com pinos dentários ou pinos de fibras de polietileno; 2) com pinos de fibras de polietileno houve ampla predominância de fratura do pino e/ou da porção coronária do núcleo; 3) com pinos dentários a fratura foi predominantemente no terço cervical da raiz, pino e/ou da porção coronária do núcleo; em condutos alargados, houve principalmente fraturas de raiz com estes pinos; 4) pinos dentários parecem ideais para reforçar raízes debilitadas, por suas propriedades biomecânicas similares às da estruturas dentária e capacidade de adesão com a mesma e com materiais restauradores.

LE BELL et al. ${ }^{71}$, em 2003, avaliaram a profundidade de polimerização de uma resina composta reforçada por fibras de vidro pré-impregnadas e silanizadas. No grupo controle, utilizou-se resina composta não reforçada. As resinas foram fotopolimerizadas (intensidade de luz de $400 \mathrm{~mW} / \mathrm{cm}^{2}$ por 40 segundos) em cilindros impermeáveis a luz com comprimentos de $4 \mathrm{~mm}, 8 \mathrm{~mm}, 12 \mathrm{~mm}, 16 \mathrm{~mm}, 20 \mathrm{~mm}$ e $24 \mathrm{~mm}$ (6 espécimes de cada comprimento). Em cada cilindro, inseriram-se a resina composta e três fibras com comprimento igual ao do cilindro. Determinou-se o grau de conversão da resina por espectrometria na extremidade oposta do cilindro a $1,5 \mathrm{~min}$, $3 \mathrm{~min}, 5 \mathrm{~min}$, 10min e 15min após a polimerização. O grau de conversão aumentou com o tempo em todos os comprimentos e foi aceitável até $20 \mathrm{~mm}$ em resinas com ou sem reforço após 10 minutos. A microdureza Vickers, medida em $0 \mathrm{~mm}, 4 \mathrm{~mm}, 8 \mathrm{~mm}, 12 \mathrm{~mm}, 14 \mathrm{~mm}$ e $16 \mathrm{~mm}$, diminuiu nos comprimentos maiores. A resina reforçada mostrou grau de conversão similar ao da resina sem reforço (possivelmente pela capacidade da fibra conduzir luz), exceto em cilindros mais longos, em que o grau de conversão da resina reforçada foi levemente menor. Os autores lembraram que pinos pré-fabricados de fibras requerem preparo prévio do canal até determinado diâmetro e cimentação com cimento resinoso, o que não é ideal, pois há remoção adicional de dentina e a adesão do cimento resinoso ao pino nem sempre é completa. Pinos de fibras confeccionados in-situ evitam mais desgaste da dentina, a adesão da resina à fibra é melhor que ao 
pino pré-fabricado e a porção coronária pode ser angulada em qualquer direção. $O$ requisito para o sucesso de pinos de fibras de vidro in-situ é obter um grau de conversão suficiente do cimento resinoso no conduto, o que o estudo demonstrou ser possível.

MONTICELLI et al. ${ }^{87}$, em 2003, avaliaram o desempenho clínico de três pinos translúcidos em 225 pacientes com pré-molares tratados endodonticamente e restaurados com pinos de fibras e coroas de cerâmica pura Empress 2. Distribuíramse os dentes em três grupos (75 dentes cada): 1) pino Aesthetic Plus; 2) pino D. T. Ligh-Post; 3) pino FRC Postec. Prepararam-se os condutos com $9 \mathrm{~mm}$ de profundidade. Para a cimentação, utilizaram-se nos grupos 1 e 2 o sistema adesivo fotopolimerizável One-Step e o cimento resinoso dual Duo-Link; no grupo 3, utilizaramse apenas materiais autopolimerizáveis (sistema adesivo Excite DSC e cimento resinoso MultiLink). Reconstruiu-se a porção coronária com resina composta fluida AeliteFlo para verificar se o material suportaria cargas funcionais por longos prazos. Após 6, 12 e 24 meses realizaram-se exame clínico e radiográfico dos dentes restaurados (e em alguns casos 30 meses após a restauração). Houve oito casos $(3,5 \%)$ de deslocamento dos pinos e seis casos de lesão periapical em dois anos. A análise estatística não revelou diferença significativa entre os pinos testados, sugerindo que todos são confiáveis para uso clínico.

KURTZ et al. ${ }^{70}$, em 2003, avaliaram, através de teste de resistência à extrusão (push-out), o efeito do sistema adesivo, cimento endodôntico e região do canal radicular sobre a resistência adesiva de três pinos estéticos. Distribuíram-se 24 dentes anteriores superiores endodonticamente tratados em três grupos iguais, nos quais foram utilizados: 1) pinos cerâmicos Cosmopost; 2) pinos de fibras de vidro FibreKor; 3) pinos de fibras de vidro Parapost Fiber White. Cimentaram-se os pinos em cada grupo com uma das seguintes combinações: 1) sistema adesivo autocondicionante Parapost Cement Conditioner e cimento resinoso autopolimerizável Parapost Cement; 2) sistema adesivo fotopolimerizável One Step (um frasco) e cimento resinoso autopolimerizável Hi-X Post. Para metade dos espécimes de cada combinação, utilizou-se um cimento endodôntico contendo eugenol e para a outra metade um cimento à base de resina epóxica. Executou-se o teste de resistência à extrusão em diferentes secções da raiz para medir a resistência adesiva em cada área do canal. Foram obtidos quatro segmentos de cada raiz por secção em máquina de corte, sendo três deles apicais à junção cemento-esmalte e um coronário a esta. Cada 
segmento era levado à máquina de ensaios, na qual aplicava-se a carga à velocidade de $1 \mathrm{~mm} / \mathrm{min}$, até deslocamento do pino. O Cosmopost mostrou adesão significativamente menor que Fibrekor e Parapost, que não diferiram entre si. A adesão dos pinos na secção coronária foi significativamente mais alta que nas demais secções da raiz (adesão similar). Concluiu-se que o tipo de pino e a área da raiz afetaram a resistência adesiva, mas o tipo de cimento endodôntico ou de adesivo não tiveram efeito sobre a adesão.

Segundo OURIQUE ${ }^{97}$, em 2003, quando fibras de vidro, cerâmicas, de carbono, de klevar ou de polietileno são incorporadas a resinas compostas, aumentam sua resistência e otimizam sua performance clínica. Discorreu sobre as fibras cerâmicas GlasSpan, encontradas em configurações de fita ( $3 \mathrm{~mm}$ de largura e 0,2mm de espessura); tubo pequeno ( $1 \mathrm{~mm}$ de diâmetro); tubo médio ( $1,5 \mathrm{~mm}$ de diâmetro) e tubo grande ou corda (2,5mm de diâmetro). As fibras devem ser manipuladas com instrumentos metálicos, sem contato com mãos ou luvas, para evitar contaminação de sua superfície. Estas fibras não interferem na estética e são de fácil utilização. São fornecidas pré-condicionadas e são ávidas por resinas, formando um corpo único com estas. Além da união química, há embricamento mecânico da resina entre a trama de fibras. Descreveu um caso de fratura do incisivo central em que usou uma fibra GlasSpan (forma de corda) para confecção de um núcleo. O conduto e a estrutura dentária passaram por condicionamento e tratamento adesivo da forma convencional. Para preparo da fibra, executou-se: 1) mensuração de $10 \mathrm{~mm}$ de fita (correspondendo ao terço cervical do conduto); 2) aplicação e polimerização de adesivo 2 a $3 \mathrm{~mm}$ antes da ponta da fita (evita desfiamento da fita); 3) corte com tesoura afiada na porção tratada; 5) aplicação de adesivo em toda a fita (sem polimerizar); 6) injetou-se resina composta fluida no tubo até extravasamento pela trama de fibras, sem polimerizar. Posicionou-se a corda no canal já preenchido com a mesma resina. Polimerizou-se cada face por 60 segundos. Executaram-se então o acabamento e o polimento.

GRANDINI ${ }^{49}$, em 2003, observou que é relativamente comum o conduto apresentar-se ovóide ou alargado. Nestes casos, é possível reembasar um pino de fibras pré-fabricado com resina composta fotopolimerizável, obtendo-se um "pino anatômico" que reproduz exatamente a morfologia do canal. O autor utilizou um pino de fibras de quartzo para a técnica, reembasado com uma resina fotopolimerizável de baixa viscosidade, a qual adere ao pino graças ao sistema adesivo. Verificou, através de microscopia eletrônica de varredura (MEV), que a espessura do cimento resinoso 
foi cerca de 6 vezes maior (ao longo de todo o canal) com pinos pré-fabricados que com pinos anatômicos. Argumentou que quanto menor a espessura do cimento, mais uniforme é a distribuição das cargas oclusais e menor a contração de polimerização do cimento resinoso (e menor o estresse por ela causado), bem como mais baixo é o número de bolhas no cimento. De fato, a MEV mostrou que com o pino anatômico houve redução significativa do número e da dimensão das bolhas no cimento resinoso. Em resumo, a técnica é a seguinte: após preparo do conduto (removendo-se áreas retentivas para permitir remoção do pino após polimerização), este deve ser isolado com água ou glicerina líquida (que deve ser eliminada com microbrush e irrigação abundante antes da cimentação). A resina composta e a seguir o pino são inseridos no conduto, procedendo-se à sua pré-polimerização. Remove-se o pino reembasado do conduto e completa-se a fotopolimerização. A cimentação é feita da mesma forma que para o pino de fibras pré-fabricado. A seguir, procede-se à construção da porção coronária do núcleo. $\mathrm{O}$ autor ressaltou que a eficácia da técnica deve ser avaliada em estudos clínicos longitudinais.

No mesmo ano, GRANDINI; SAPIO; SIMONETTI ${ }^{50}$ propuseram a técnica do pino anatômico como rotina clínica para condutos de forma irregular ou alargados. Ressaltaram que na última situação é contra-indicada a remoção adicional de dentina na busca de uma melhor adaptação do pino ao conduto. Uma significativa melhora na adaptação dos pinos de fibras pode ser conseguida com o pino anatômico, geralmente melhor que a de qualquer pino pré-fabricado. A adaptação precisa proporciona uma fina e uniforme película de cimento resinoso, que favorece a retenção do pino e previne falhas adesivas e deslocamento precoce do pino. Além disso, a técnica dispensa envolvimento laboratorial. O procedimento pode ser utilizado sempre que a adaptação do pino ao conduto for imperfeita. Descreveram a confecção de um pino anatômico em um incisivo central superior com fratura coronária acima do terço médio. Após tratamento endodôntico, verificou-se adaptação inadequada do pino pré-fabricado ao conduto. Inicialmente, removeram-se as retenções presentes no conduto, que foi então lubrificado com glicerina. Depois de inserida a resina no conduto, o pino foi introduzido no mesmo. A resina foi polimerizada por 20 segundos e o pino foi removido do conduto, procedendo-se à polimerização adicional da resina por 20 segundos. A seguir, verificou-se se o pino adaptava-se no conduto sem dificuldades. A cimentação foi executada da forma convencional. 
NEWMAN et al. ${ }^{92}$, em 2003, compararam os efeitos de três sistemas de pinos de fibras sobre a resistência à fratura e modo de falha de dentes despolpados. Distribuíram 90 incisivos centrais superiores em oito grupos experimentais e um grupo controle, no qual utilizou-se pino de aço inoxidável Para-Post de 1,5mm (10 espécimes cada grupo). Metade dos dentes dos grupos experimentais possuía condutos estreitos e a outra metade condutos alargados. Em espécimes com canais estreitos, prepararam-se os condutos com a broca correspondente para pinos de fibras de vidro FibreKor $(1,5 \mathrm{~mm})$ ou Luscent Anchors $(1,6 \mathrm{~mm})$; os pinos de fibras de polietileno Ribbond foram confeccionados diretamente em condutos de $1,6 \mathrm{~mm}$ de diâmetro. Os mesmos pinos foram cimentados nos condutos largos, que possuíam preparo cônico com $2 \mathrm{~mm}$ de diâmetro na porção mais cervical da raiz e $1,5 \mathrm{~mm}$ no ápice, feito com pontas diamantadas tronco-cônicas. Em condutos estreitos, cimentaram-se os pinos pré-fabricados com cimento resinoso autopolimerizável Cement-It! (usado também para cimentar o pino ParaPost), e em condutos largos com resina composta fluida Flow-It!. Os pinos de Ribbond foram confeccionados com resina fluida fotopolimerizável Flow-It! para os dois tipos de condutos; nos condutos estreitos utilizaram-se dois pedaços de Ribbond com $2 \mathrm{~mm}$ x $28 \mathrm{~mm}$ e nos condutos largos três pedaços do mesmo tamanho. Preparam-se todos os condutos até $10 \mathrm{~mm}$ de profundidade e em todos os grupos utilizou-se o adesivo Scotchbond Multi-uso de forma dual. Preparou-se ainda um grupo chamado de "Ribbond não-padronizado", com 20 pinos de Ribbond e porção coronária de forma e tamanho variável, cujos resultados foram excluídos da análise estatística devido à falta de padronização. Os espécimes foram submetidos ao teste de resistência à fratura à velocidade de $5 \mathrm{~mm} / \mathrm{min}$. Não houve diferença significativa na resistência entre condutos estreitos ou alargados com os pinos testados, exceto para o Ribbond (maior valor em condutos largos). Em canais estreitos, a menor resistência foi 4,55kgf para Ribbond e a mais alta foi $12,9 \mathrm{kgf}$ para Luscent Anchors. Em canais largos, a menor resistência foi 9,04kgf para FibreKor e a mais alta $(12,87 \mathrm{kgf})$ foi igual para Luscent Anchors e Ribbond. O grupo com maior resistência à fratura foi o controle (18,33kgf). O grupo do Ribbond não-padronizado obteve média de 24,91kgf para condutos estreitos e de $31,95 \mathrm{kgf}$ para condutos largos. Não ocorreu fratura radicular em nenhum dos grupos experimentais, e no grupo controle houve três fraturas no terço cervical da raiz. Concluiu-se que embora pinos metálicos tenham apresentado maior resistência que pinos de fibras, o modo de falha dos últimos protege o remanescente dentário. 
PURTON; CHANDLER; QUALTROUGH ${ }^{104}$, em 2003, investigaram o efeito da termociclagem sobre a retenção de pinos de fibras de vidro. Distribuíram-se 40 raízes de caninos e pré-molares em dois grupos (20 espécimes cada), nos quais cimentaram-se pinos Lightpost ou Luscent Anchors com cimento resinoso. As coroas foram removidas, os condutos preparados com $9 \mathrm{~mm}$ de profundidade e as raízes embebidas em blocos de resina acrílica. Cada grupo foi subdividido em dois subgrupos iguais: um foi submetido à termociclagem (3.000 ciclos em banhos de água a $5^{\circ} \mathrm{C}$ e $55^{\circ} \mathrm{C}$, com 60 segundos em cada banho de água e tempo de transferência de dois segundos) e o outro serviu como controle (espécimes armazenados a $37^{\circ} \mathrm{C}$ ). Os espécimes foram submetidos à força de tração no longo eixo do pino, à velocidade de $5 \mathrm{~mm} / \mathrm{min}$. No grupo controle, a força necessária para deslocar os pinos foi $31,5 \mathrm{kgf}$ para o pino Lightpost e 15,49kgf para o pino Luscent Anchors (diferença significativa); nos grupos com termociclagem, obteve-se 23,04kgf para Lightpost e 17,02kgf para Luscent Anchors (diferença não significativa). Não houve diferença significativa na retenção entre espécimes submetidos ou não à termociclagem. Todos os pinos tinham remanescentes de cimento, sugerindo falha adesiva na interface cimento-dentina, ou falha coesiva dentro do cimento, ou ainda associação de ambas. Considerou-se que pinos de fibras de vidro cimentados com cimento resinoso ofereceram retenção aceitável, que não diminuiu com a termociclagem, indicando não ser essencial usar a termociclagem em testes de retenção de pinos de fibras cimentados com cimentos resinosos.

DRUMMOND; BAPPA ${ }^{25}$, em 2003, avaliaram a resistência à flexão de pinos de fibras de carbono (Carbon-Post), pinos cerâmicos (Zirconia-Post) e pinos de fibras de vidro (Esthetic-Post, Light-Post, Luscent Anchors e FibreKor de três diâmetros diferentes) antes e após ciclagem térmica, examinado também o efeito da carga estática e cíclica sobre esses materiais. O diâmetro dos pinos variou de 0,98 a $1,90 \mathrm{~mm}$. Submeteram-se 10 pinos de cada grupo a ciclagem térmica (6000 ciclos entre 7 e $63^{\circ} \mathrm{C}$ ) e um número igual de pinos de cada grupo não sofreram ciclagem térmica. Barras de resina reforçada por fibras de vidro unidirecionais também foram submetidas a ciclagem térmica e cargas cíclicas. Executaram-se os testes à velocidade de $2 \mathrm{~mm} / \mathrm{min}$ na máquina de ensaios, com os espécimes imersos em água ou em ambiente seco. Realizou-se o teste de fadiga sob a mesma velocidade, até 1000 ciclos, com carga de $40 \mathrm{~kg}$. A microscopia eletrônica de varredura foi usada para avaliar diferenças microestruturais entre os pinos e a qualidade de aderência das fibras à matriz resinosa. Os pinos de fibras de carbono e o pino de fibras de vidro 
FibreKor foram significativamente mais resistentes que o pino cerâmico e que os demais pinos de fibras de vidro. A ciclagem térmica reduziu significativamente a resistência à flexão dos pinos de fibras de carbono ou vidro. Com barras de resina reforçadas, não houve diferença significativa com o teste em ambiente úmido ou seco, mas houve perda significativa de resistência sob carga cíclica; a ciclagem térmica diminuiu a resistência em 11\%. Freqüentemente observaram-se depressões irregulares ou vazios nas áreas de fratura. Não houve falta de adesão entre fibras e matriz resinosa com nenhum pino. Concluiu-se que a diminuição da resistência sob carga cíclica e sob ciclagem térmica de pinos de fibras indica que seu uso no ambiente oral aumenta sua degradação, encurtando a vida clínica.

LERTCHIRAKARN; PALAMARA; MESSER ${ }^{72}$, em 2003, ressaltaram que estudos anteriores indicaram que fraturas radiculares verticais tendem a ocorrer em direção vestíbulo-lingual. Os fatores que provavelmente influenciam na localização e direção da fratura da raiz são forma do conduto, morfologia externa da raiz e espessura da parede radicular. Utilizou-se o método do elemento finito, variando forma e diâmetro do conduto, morfologia externa da raiz e espessura da dentina para determinar sua contribuição para a fratura vertical. Desenvolveram-se seis modelos de dentina radicular e conduto: Modelo I - raiz simetricamente cilíndrica (parede da raiz com $1 \mathrm{~mm}$ de espessura) e canal com $1 \mathrm{~mm}$ de diâmetro; Modelo II - raiz oval (1mm no sentido vestibular e lingual e $0,5 \mathrm{~mm}$ proximal) e conduto com $1 \mathrm{~mm}$ de diâmetro; Modelo III - raiz arredondada e conduto com $1 \mathrm{~mm}$ vestibular e lingual e $0,5 \mathrm{~mm}$ proximal; Modelos IV a VI - forma do conduto igual a do modelo III; raiz sempre com $1 \mathrm{~mm}$ vestibular e lingual, variando-se a espessura proximal $(1 \mathrm{~mm}$ no modelo IV, $0,75 \mathrm{~mm}$ no modelo $\mathrm{V}$ e $0,5 \mathrm{~mm}$ no modelo $\mathrm{VI}$ ). Desenvolveram-se mais dois modelos por digitalização de raízes fraturadas assimetricamente em função, acrescentando-se o ligamento periodontal. O modelo VII era um incisivo inferior com canal oval, raiz oval (espessura duas vezes maior no sentido vestíbulo-lingual que mésio-distal) e linha de fratura vestíbulo-lingual. O modelo VIII era um pré-molar superior com conduto palatino alargado, duas linhas de fratura na face lingual da raiz e outra linha de fratura na face vestibular. Nos modelos de I a VI aplicou-se carga de $1 \mathrm{~N}$ em direção perpendicular à superfície do conduto (distribuição uniforme do estresse circunferencial) e nos modelos VII e VIII aplicou-se carga de $60 \mathrm{~N}$, com a mesma direção. Os resultados sugeriram que a forma do conduto é mais importante para concentração de estresse que a morfologia externa da raiz, e que uma menor espessura da parede da raiz aumenta a magnitude, mas não a direção do estresse. 
Os modelos usados no teste mostraram alta similaridade entre as áreas de maior estresse e os padrões de fratura vistos em raízes humanas fraturadas cinicamente ou in vitro.

QUALTROUGH; CHANDLER; PURTON ${ }^{105}$, em 2003, compararam a retenção de cinco pinos estéticos, usando como controle pinos de titânio. Sessenta dentes unirradiculares despolpados foram seccionados $1 \mathrm{~mm}$ acima da junção cemento-esmalte e fixados em blocos de resina acrílica. Distribuíram-se os espécimes em seis grupos de 10 unidades: 1) Para-Post de titânio $n^{\circ} 6$ (1,5mm); 2) Lightpost cônico $n^{\circ} 2$ (1,8mm); 3) Lightpost paralelo $n^{\circ} 2$ (1,8mm); 4) Parapost Fiberwhite $n^{\circ} 6$ $(1,5 \mathrm{~mm})$; 5) Snowpost $(1,6 \mathrm{~mm})$; 6) Dentatus Luscent Anchor (1,5mm). Os pinos utilizados nos grupos 1 a 5 eram de fibras de vidro. Os condutos foram preparados conforme instruções dos fabricantes dos pinos, que foram cimentados com cimento resinoso. Um anel oco de $4 \mathrm{~mm}$ de diâmetro foi cimentado sobre a porção coronária de cada pino para conexão à máquina de ensaios. Após armazenamento dos espécimes em soro fisiológico a $37^{\circ} \mathrm{C}$, executou-se o ensaio de resistência à remoção por tração, à velocidade de $5 \mathrm{~mm} / \mathrm{min}$. Os resultados foram: Grupo 1 - 13kgf; Grupo 2 - 12kgf; Grupo 3 - 31,01kgf; Grupo 4 - 21kgf; Grupo 5 -10kgf; Grupo 6 - 15kgf. O pino paralelo Lightpost foi significativamente mais retentivo que os demais. $O$ pino Parapost Fiberwhite foi mais retentivo que os pinos cônicos Lightpost e Snowpost. Não houve diferença significativa entre a retenção do pino metálico serrilhado e paralelo em relação aos grupos de pinos estéticos. A dimensão dos pinos influenciou na retenção, e os pinos paralelos foram mais retentivos que os cônicos. Devido ao seu potencial adesivo, características retentivas da superfície parecem menos importante para a retenção de pinos de fibras que para pinos metálicos.

PITEL; HICKS ${ }^{100}$, em 2003, observaram que o desenvolvimento de pinos estéticos foi impulsionado pelo crescente interesse dos pacientes em restaurações livres de metal, uma vez que núcleos metálicos fundidos ou pinos metálicos poderiam torná-las acinzentadas e interferir com a transmissão da luz através do dente e gengiva marginal. Além disso, é comum a formação de produtos de corrosão por pinos metálicos, que causam pigmentação da dentina e geram uma coloração azul ou cinza na gengiva marginal. Por outro lado, pinos de fibras possuem propriedades físicas altamente favoráveis. O primeiro pino não-metálico foi o pino de fibras de carbono, desenvolvido na França no início da década de 1990. Este pino tem hoje sólida história de sucesso clínico, mas sua cor negra não é estética. Logo 
surgiram pinos mais estéticos, com cobertura mineral branca sobre o carbono (Aestheti-Post); porém, a transmissão de luz ainda era baixa. Hoje, os pinos mais estéticos são os de fibras de vidro ou quartzo, classificados em: 1) translúcidos (LightPost, Luscent Anchors), possibilitando transmissão de luz quase normal através da estrutura dentária, efeito camaleônico (sua cor confunde-se com a do material de preenchimento coronário) e condução da luz do fotopolimerizador para o canal; ou 2) branco-opacos (FibreKor, Aestheti-Plus, Parapost Fiber White). Sobre o pino de fibras de vidro FibreKor, observaram que a porcentagem de fibras na matriz é de $42 \%$, a resistência à flexão é de $960 \mathrm{GPa}$ e a resistência à tração é de $1200 \mathrm{MPa}$. Os pinos cerâmicos, por serem opacos, são menos estéticos que pinos de fibras translúcidos, possuem adesão pouco previsível e módulo de elasticidade idêntico ao de pinos de aço (altamente rígidos). Pinos rígidos não reforçam a raiz de dentes despolpados e ainda transmitem o estresse funcional para esta, aumentando o risco de fraturas, inclusive irreversíveis. Pinos de fibras não sofrem corrosão, que pode diminuir a adesão, além de possuir módulo de elasticidade similar ao da dentina (15GPa a 40GPa), que permite distribuição mais uniforme do estresse na estrutura dentária e nas interfaces entre materiais restauradores e estrutura dentária. A resistência à flexão dos pinos de fibras também é adequada (mais alta que a do aço ou titânio). Pinos mais recentes (D.T. Light-Post) possuem formas similares aos condutos, melhorando a adaptação ao conduto com mínimo preparo; outros pinos possuem sulcos para aumento da retenção. A maioria dos pinos de última geração é radiopaca. Estudos clínicos e laboratoriais demonstraram que pinos de fibras reduzem dramaticamente a incidência de fratura radicular, descoloração dental e reações alérgicas.

SAHAFI et al. ${ }^{113}$, em 2003, determinaram o efeito do tratamento superficial sobre a resistência adesiva dos cimentos resinosos Panavia $\mathrm{F}$ e ParaPost Cement a pinos de liga de titânio (ParaPost $\mathrm{XH}$ ), fibras de vidro (ParaPost Fiber White) e zircônia (Cerapost), bem como à dentina. Após embebidos em resina acrílica autopolimerizável, espécimes dos pinos $(n=9$ a 14) e dentes $(n=10)$ foram desgastados até a obtenção de discos com superfícies planas e diâmetro de 1,5mm. Os espécimes foram deixados sem tratamento (controle) ou receberam um de três tratamentos de superfície: 1) micro-asperização (jateamento com partículas de alumina ou condicionamento com ácido hidrofluorídrico); 2) aplicação de solução química visando adesão química entre cimento e pino (Alloy Primer, Metalprimer II, silano); 3) micro-asperização seguida da aplicação de solução química (jato de areia ou condicionamento seguido por primer, tratamento com Cojet). Na Figura 2.3, pode- 
se observar o tratamento aplicado em cada pino. Utilizando-se como matriz um cilindro oco com 1,5mm de altura, aplicaram-se os cimentos resinosos sobre os espécimes de pinos e de dentina, que foram então imersos em água a $37^{\circ} \mathrm{C}$ por sete dias e depois submetidos ao teste de resistência ao cisalhamento à velocidade de $1 \mathrm{~mm} / \mathrm{min}$. $A$ maioria dos tratamentos aumentou a resistência adesiva dos cimentos aos três pinos; Cojet e jato de areia foram geralmente os tratamentos mais efetivos. Com pinos não tratados, o Panavia $\mathrm{F}$ mostrou maior adesão ao ParaPost $\mathrm{XH}$ e Cerapost que o ParaPost Cement. O Panavia $\mathrm{F}$ apresentou maior adesão à dentina que o ParaPost Cement.

\begin{tabular}{l|l} 
Tratamento de superfície & Tipo de pino \\
\hline Controle (sem tratamento) & $\mathrm{XH}, \mathrm{FW}, \mathrm{CP}$ \\
\hline Jateamento com partículas de alumina $(50 \mu \mathrm{m})$ & $\mathrm{XH}, \mathrm{FW}, \mathrm{CP}$ \\
\hline Condicionamento com ácido hidrofluorídrico a 9,6\% & $\mathrm{XH}, \mathrm{FW}, \mathrm{CP}$ \\
\hline $\begin{array}{l}\text { Cojet (jato com partículas de alumina de } 30 \mu \text { cobertas } \\
\text { por silicato, seguido por silano) }\end{array}$ & $\mathrm{XH}, \mathrm{FW}, \mathrm{CP}$ \\
\hline Alloy Primer & $\mathrm{XH}$ \\
\hline Metalprimer II & $\mathrm{XH}$ \\
\hline Jato de areia e Alloy Primer & $\mathrm{XH}$ \\
\hline Jato de areia e Metalprimer II & $\mathrm{XH}$ \\
\hline Condicionamento e Alloy Primer & $\mathrm{XH}$ \\
\hline Condicionamento e Metalprimer II & $\mathrm{XH}$ \\
\hline Silano & $\mathrm{FW}, \mathrm{CP}$ \\
\hline Jato de areia e silano & $\mathrm{FW}, \mathrm{CP}$ \\
\hline $\begin{array}{l}\text { Condicionamento e silano } \\
\text { Legenda: } \mathrm{XH}=\text { ParaPost } \mathrm{XH}, \mathrm{FW}=\text { ParaPost Fiber White, CP = Cerapost }\end{array}$
\end{tabular}

FIGURA 2.3 - Tratamento superficial aplicado nos diferentes sistemas de pinos (SAHAFI et al., 2003)

HU et al. ${ }^{58}$, em 2003, avaliaram a resistência à fratura e padrões de falha de incisivos centrais superiores despolpados e distribuídos em quatro grupos (10 espécimes cada), com diferentes tipos de núcleos. Os condutos foram desobturados, preservando-se $4 \mathrm{~mm}$ da obturação radicular. Após execução de preparo para coroa total com chanfrado de $1,2 \mathrm{~mm}$ de largura ao nível da junção cemento-esmalte (JCE), as coroas foram removidas, mantendo-se $1 \mathrm{~mm}$ de estrutura dentária acima da JCE. No Grupo 1, utilizaram-se núcleos metálicos fundidos em ouro-paládio, com porção radicular paralela e serrilhada, obtida a partir de padrões Parapost calcináveis. O canal 
foi preparado com a broca paralela Parapost $n^{0} 4(1 \mathrm{~mm}$ de diâmetro). Para a cimentação, utilizou-se cimento de policarboxilato. No grupo 2, os dentes receberam pinos de aço inoxidável paralelos e serrilhados Parapost ( $1 \mathrm{~mm}$ de diâmetro). No grupo 3, utilizaram-se pinos de fibras de carbono-quartzo paralelos e de ápice cônico Aestheti-Post $\mathrm{n}^{\circ} 1$ ( $1 \mathrm{~mm}$ de diâmetro). No grupo 4, utilizaram-se pinos cerâmicos paralelos e de ápice cônico ER-Cerapost $(0,9 \mathrm{~mm}$ de diâmetro). Nos grupos 2 a 4, a porção coronária foi confeccionada com resina composta e os pinos cimentados com cimento resinoso dual. As raízes foram fixadas em blocos de resina acrílica. Cimentaram-se coroas totais metálicas sobre os núcleos. Após armazenamento em soro fisiológico à temperatura ambiente por sete dias, submeteram-se os espécimes à compressão em ângulo de $45^{\circ} \mathrm{com}$ o longo eixo da raiz, à velocidade de $2,5 \mathrm{~mm} / \mathrm{min}$. O modo de falha foi classificado como: 1) deslocamento do pino; 2) fratura de estrutura dental coronária; 3) fratura da raiz (localização variável). Para facilitar a localização da falha, os espécimes foram imersos após o teste em solução de fucsina básica, embebidos em resina epóxica e então seccionados longitudinalmente em máquina de corte. Os valores de resistência à fratura encontrados foram aceitáveis em todos os grupos: grupo 1 - 36,92kgf; grupo 2 - 25,80kgf; grupo 3 - 29,34kgf; e grupo 4 $33,02 \mathrm{kgf}$. Não houve diferença significativa entre os quatro grupos quanto à resistência. A incidência de fratura da raiz nos grupos 1, 2, 3 e 4 foi de $100 \%, 70 \%$, $90 \%$ e $100 \%$, respectivamente. Nove de 10 pinos cerâmicos fraturaram e três de 10 pinos de aço inoxidável deslocaram.

REID; KAZEMI; MEIERS ${ }^{107}$, em 2003, executaram um teste não destrutivo para avaliar simultaneamente a incidência e o modo de falha do núcleo após teste de fadiga, bem como a micro-infiltração nos núcleos. Restauraram-se 50 dentes unirradiculares despolpados e com as coroas removidas com cinco pinos diferentes e porção coronária em resina composta, formando cinco grupos iguais:1) ParaPost (titânio); 2) CosmoPost (cerâmico); 3) C-Post (fibras de carbono); 4) Esthetic C-Post (carbono-quartzo); 5) FibreKor (fibras de vidro). Cimentou-se o pino metálico com fosfato de zinco e os demais pinos com cimento resinoso. Os espécimes foram fixados em blocos de resina acrílica e sujeitos a 100.000 impactos na máquina de ensaios (equivalendo a seis meses de mastigação), em $45^{\circ}$ com o longo eixo dentário, com carga de 5,6kgf (baixo impacto) e freqüência de $3 \mathrm{~Hz}$. Durante o teste de fadiga, os espécimes permaneceram em água à temperatura ambiente. Após 60.000 impactos, os espécimes foram termociclados por 1.000 vezes entre $5^{\circ} \mathrm{C}$ e $55^{\circ} \mathrm{C}$ (mantidos em cada banho por 30 segundos, com intervalos de 10 segundos). Avaliou-se a micro- 
infiltração no início do teste de fadiga, após 30.000 impactos, 60.000 impactos (após termociclagem) e ao final do teste. A infiltração aumentou a cada medição em todos os grupos, mas após a termociclagem foi maior em pinos não-metálicos que nos metálicos. Todos os espécimes atingiram 100.000 impactos sem deslocar e sem fratura da porção coronária ou da raiz. Pinos metálicos mostraram maior microinfiltração que pinos não-metálicos ao final do estudo. Consideraram satisfatório o desempenho dos pinos não-metálicos em ambos os quesitos testados.

FOKKINGA et al. ${ }^{38}$, em 2004, executaram uma revisão sistemática agregando dados de estudos laboratoriais sobre a carga de falha e modos de falha de pinos de pré-fabricados de fibras, metálicos e cerâmicos. Após revisão de 1984 artigos do MEDLINE entre 1984 e 2003 sobre o assunto, 12 artigos foram selecionados. Os critérios de inclusão foram: 1) comparação de pinos pré-fabricados de fibras com qualquer outro tipo de núcleos; 2) dentes unirradiculares; e 3) resina composta como material de reconstrução coronária. Os autores observaram que núcleos metálicos fundidos mostraram cargas de falha significativamente maiores que pinos de fibras, e pinos cerâmicos tiveram cargas de falha significativamente menores que pinos de fibras. O modo de falha foi significativamente mais favorável com pinos de fibras que com pinos pré-fabricados metálicos ou núcleos metálicos fundidos, provavelmente porque pinos de fibras possuem módulo de elasticidade similar ao da dentina. Porém, quando pinos de fibras com diâmetros maiores forem usados, sua rigidez também será maior. Pinos cerâmicos, apesar de mais resistentes que pinos de fibras, fraturam com cargas mais baixas que estes por serem muito friáveis; o pino cerâmico geralmente fratura antes do que a raiz.

MORGANO; RODRIGUES; SABROSA ${ }^{89}$, em 2004, dissertaram sobre a restauração de dentes tratados endodonticamente. Afirmaram que pinos intraradiculares enfraquecem dentes despolpados, ao invés de reforçá-los, devendo ser indicados apenas se não há estrutura coronária suficiente para reter a restauração dentária. Quando o comprimento do pino é adequado (similar à altura da coroa clínica), a taxa de insucesso é de apenas 2,5\%. Coroas totais com férula em dentes despolpados mostram maior resistência à fratura in vitro do que coroas sem férula, bem como maior taxa de sucesso clínico (deve haver pelo menos 1,5 a $2 \mathrm{~mm}$ de estrutura dental sadia acima da margem da coroa em torno de todo o preparo). Ressaltaram que dois estudos encontraram aumento do potencial para fratura da raiz com pinos cônicos; porém, outra pesquisa não encontrou diferença na distribuição do 
estresse entre pinos cônicos e paralelos. Em dentes unirradiculares, pinos cônicos são mais recomendados que paralelos porque seus canais tornam-se cônicos após instrumentação endodôntica. Para alcançar maiores taxas de sucesso com núcleos metálicos fundidos em dentes unirradiculares, recomendaram que: sejam tão longos quanto possível, preservando-se 4 a $5 \mathrm{~mm}$ do selamento apical; devem seguir a conicidade natural do canal instrumentado, conservando estrutura dentária; deve haver um stop coronário para o núcleo, diminuindo o efeito de cunha no interior da raiz; obtenção de férula, se possível. Quando há remanescente de mais de $50 \%$ da estrutura dental coronária, podem-se indicar pinos pré-fabricados para confecção de núcleo de preenchimento. Pinos rosqueados são mais retentivos que os passivos, mas predispõem à fratura da raiz. A retenção de pinos passivos é maior quando são paralelos e rugosos. Estudos in vitro indicaram que pinos de fibras são menos resistentes que núcleos metálicos fundidos, e sua resistência diminui mais com armazenamento em água ou termociclagem. Por serem flexíveis, teoricamente podem contribuir para falhas no selamento da coroa, especialmente se a férula é mínima.

PERDIGÃO; GERALDELI; LEE $^{98}$, em 2004, avaliaram a resistência à extrusão (push-out) de pinos de fibras e pinos cerâmicos em diferentes áreas do conduto, variando sistemas adesivos e cimentos resinosos. Distribuíram-se 32 dentes anteriores despolpados em oito grupos (quatro espécimes cada): 1) pino cerâmico Cosmopost, sistema adesivo dual Excite DSC e cimento dual Variolink II; 2) pino Cosmopost, sistema adesivo fotopolimerizável Excite e cimento Variolink II; 3) pino Cosmopost, sistema adesivo Excite DSC e cimento Experimental Self Cure Cement; 4) pino de fibras de vidro FRC Postec, sistema adesivo Excite DSC e Variolink II; 5) pino FRC Postec, sistema adesivo fotopolimerizável Syntac Classic e cimento Variolink II; 6) pino FRC Postec, sistema adesivo Excite DSC e cimento Experimental Self Cure Cement; 7) pino de fibras de carbono C-Post, sistema adesivo One-Step e cimento Post Cement Hi-X (grupo apenas de materiais fotopolimerizáveis); 8) pino de fibras de vidro ParaPost Fiber White, sistema adesivo ParaPost e cimento ParaPost Resin (grupo apenas de materiais autopolimerizáveis). As raízes foram incluídas em blocos de resina acrílica, seccionadas para obtenção de fatias dos terços cervical, médio e apical do conduto preparado, e armazenadas em água destilada. A seguir, executouse o teste de extrusão em cada secção para medir a resistência adesiva regional. A resistência à extrusão é calculada com a fórmula Resistência ao deslocamento $(\mathrm{kg}) /$ $A$, onde $A$ é igual à área da interface pino/dentina. Independentemente da área da raiz, os pinos de fibras apresentaram valores significativamente maiores que os cerâmicos, 
na seguinte ordem: grupo 8, grupo 5, grupo 4, grupo 6, grupo 7, grupo 1 , grupo 3 , e grupo 2. As médias obtidas no terço médio da raiz foram estatisticamente similares às obtidas nos terços cervical e apical, independentemente do cimento. As médias da região cervical do canal foram estatisticamente maiores que as da região apical, provavelmente porque: 1) há menor número de túbulos dentinários na região apical que na cervical; 2) o condicionamento ácido e tratamento adesivo são mais fáceis de executar na área cervical do conduto.

GRANDINI et al. ${ }^{51}$, em 2004, avaliaram a eficácia de dois procedimentos para cimentação de pinos de fibras de vidro na formação da camada híbrida, tags de resina e ramificações laterais de adesivo. Distribuíram-se 40 dentes incisivos e caninos inferiores despolpados em quatro grupos iguais, nos quais cimentaram-se pinos de fibras de vidro translúcidos D. T. (Double Taper) Light Post: 1) adesivo One-Step fotopolimerizado por 20 segundos (FP 20seg.) e cimento resinoso dual Duo-Link fotopolimerizado por 20seg.; 2) One-Setp não fotopolimerizado (NFP) e cimento Duo-Link (FP 30seg.); 3) One-Step (NFP) e cimento Duo-Link (FP 60 seg.); 4) One-Step (NFP) e cimento Duo-Link (FP 90 seg.). A técnica de fotopolimerização em um passo usada nos grupos 2 a 4 baseia-se no potencial de transmissão da luz pelo pino translúcido. Prepararam-se os condutos até $9 \mathrm{~mm}$ de profundidade abaixo da junção cemento-esmalte. Utilizaram-se pinos de três diâmetros diferentes, de acordo com a largura do canal. Após a cura completa do cimento, armazenaram-se os dentes em água a temperatura ambiente por sete dias. As raízes foram longitudinalmente seccionadas e preparadas para microscopia eletrônica de varredura (MEV) para avaliar a continuidade da camada híbrida, presença ou ausência de gaps e a densidade e morfologia de tags de resina. A camada híbrida foi mais evidente, uniforme e com menos gaps no grupo 1 que nos demais, especialmente no terço apical do canal. Entre os demais grupos não houve diferença nas características da camada híbrida. Os tags de resina possuíam adequado comprimento e uniformidade nos terços cervical e médio em todos os grupos, e no terço apical do grupo 1. No terço apical dos grupos 2 a 4, os tags de resina eram mais curtos e menos uniformes. Do ponto de vista da MEV, a polimerização do adesivo antes da inserção do cimento foi mais eficaz para a cimentação do pino de fibras de vidro translúcido.

AKKAYAN $^{3}$, em 2004, comparou o efeito de três comprimentos de férula sobre a resistência à fratura e padrões de falha em dentes despolpados e restaurados com pinos estéticos. Removeram-se as coroas de 123 caninos superiores 
e prepararam-se três deles com férulas de $1,00 \mathrm{~mm}, 1,5 \mathrm{~mm}$ e 2,00mm, que depois foram moldados com silicone de adição e reproduzidos em resina acrílica autopolimerizável para produzir padrões de cada comprimento de férula. Utilizando-se estes padrões, obtiveram-se, no sistema fresador Celay, 40 dentes preparados com cada comprimento de férula, formando três grupos. Cada grupo foi dividido em quatro sub-grupos de 10 espécimes restaurados com: 1) pinos de fibras de quartzo D. T. Light-Post; 2) pinos de fibras de vidro ER DentinPost; 3) pinos de fibras de vidro associadas à zircônia EasyPost; 4) pinos de zircônia Cosmopost. Cimentaram-se os pinos com cimento resinoso. A porção coronária dos núcleos foi reconstruída com resina composta e recoberta com coroas totais metálicas. Submeteram-se os dentes à carga de compressão em ângulo de $130^{\circ}$ com seu longo eixo, à velocidade de $1 \mathrm{~mm} / \mathrm{min}$. Classificaram-se as falhas como localizadas no terço cervical da raiz ou abaixo dele. Os seguintes valores de resistência à fratura (kgf) para pinos de fibras de quartzo, de fibras de vidro, de fibras de vidro mais zircônia, ou de zircônia foram, respectivamente: 98,09; 85,36; 80,24; e 70,11 (férula de 1,0mm); 101,00; 87,58; 89,8; e 82,71 (férula de 1,5mm); e 119,5; 99,84; 98,6; e 95,42 (férula de 2,00mm). 0 aumento do comprimento da férula de $1,00 \mathrm{~mm}$ para $1,5 \mathrm{~mm}$ em dentes com pinos de fibras de quartzo ou de fibras de vidro não aumentou significativamente a resistência à fratura, mas a férula de $2 \mathrm{~mm}$ aumentou significativamente a resistência com todos os pinos. Não houve diferença significativa nos padrões de fratura dentro dos sub-grupos ou entre grupos. Com os três comprimentos de férula, a resistência foi significativamente maior com pinos de fibras de quartzo que com outros tipos de pinos. Houve diferença significativa entre os tipos de pinos dentro dos quatro sub-grupos com os três comprimentos de férula, exceto entre pinos de fibras de quartzo e de fibras de vidro com férulas de $1,0 \mathrm{~mm}$ e $1,5 \mathrm{~mm}$.

SAHAFI et al. ${ }^{112}$, em 2004, avaliaram o efeito do cimento, bem como do desenho, material e tratamento superficial do pino sobre a retenção e o tipo de falha de pinos de titânio (ParaPost $\mathrm{XH}$ ), de fibras de vidro (ParaPost Fiber White) ou de zircônia (Cerapost cônico ou paralelo). Na Figura 2.4 observam-se os tratamentos de

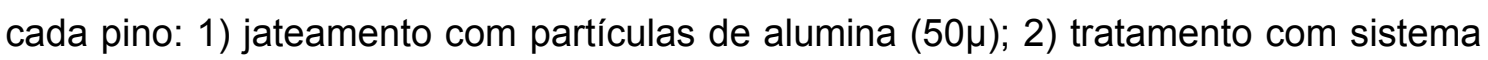
CoJet (partículas de alumina de $30 \mu$ cobertas por silicato, seguidas por silano); 3 ) aplicação de Metalprimer II; e 4) jato de areia seguido por silano. O controle foram pinos não tratados. Os pinos foram cimentados em condutos de incisivos ou caninos (10 espécimes cada grupo) preparados até $5 \mathrm{~mm}$ de profundidade, com três tipos de cimento: 1) fosfato de zinco (DeTrey Zinc); 2) cimento resinoso convencional baseado 
em Bis-GMA (ParaPost Cement); 3) cimento resinoso contendo MDP (Panavia F). Após armazenamento em água a $37^{\circ} \mathrm{C}$ por 7 dias, executou-se o teste de retenção. $\mathrm{O}$ padrão de falha foi quantificado em microscópio óptico pela área do pino coberta por cimento (APCC); um alto valor de APCC indica boa adesão. Quanto ao tratamento superficial: 1) nenhum dos tratamentos aumentou a retenção do pino ParaPost $\mathrm{XH}$, mas todos aumentaram a APCC; 2) todos os tratamentos diminuíram a retenção do pino ParaPost Fiber White quando cimentado com ParaPost Cement, mas quando cimentado com Panavia F o jato de areia aumentou sua retenção; apenas o Panavia F aumentou a APCC deste pino; 3) todos os tratamentos aumentaram a retenção do pino Cerapost quando cimentado com ParaPost Cement, mas com Panavia F nenhum tratamento aumentou a retenção. O aumento da retenção proporcionado pelos diferentes tratamentos foi apenas moderado, devido à limitada adesão dos cimentos à dentina. Quanto à forma do pino, o pino Cerapost paralelo foi mais retentivo que o cônico, mas sem diferença na APCC; a retenção do Cerapost (pino liso) foi menor que a de ambos os pinos ParaPost (com macro-retenções). O tipo de cimento teve efeito significativo na retenção para os pinos não tratados, mas influenciou a APCC somente com ParaPost XH e ParaPost FiberWhite. A retenção do ParaPost XH e do ParaPost FiberWhite foi maior com ParaPost Cement, e a retenção do Cerapost foi maior com Panavia F.

\begin{tabular}{l|l} 
Tratamento superficial & Pinos \\
\hline Nenhum & $\mathrm{XH}, \mathrm{FW}, \mathrm{CP}$ \\
\hline Jateamento com partículas de alumina & $\mathrm{XH}, \mathrm{FW}, \mathrm{CP}$ \\
\hline Metal Primer II & $\mathrm{XH}, \mathrm{FW}, \mathrm{CP}$ \\
\hline Sistema CoJet & $\mathrm{XH}$ \\
\hline Jateamento com partículas de alumina e silano & $\mathrm{XH}, \mathrm{CP}$
\end{tabular}

Legenda: $\mathrm{XH}=$ ParaPost $\mathrm{XH}, \mathrm{FW}=$ ParaPost Fiber White, $\mathrm{CP}=$ Cerapost

FIGURA 2.4 - Tratamento superficial aplicado em cada pino (SAHAFI et al., 2004)

BERGER; CAVINA ${ }^{12}$, em 2004, ressaltaram que entre os pinos intraradiculares recentemente lançados destacam-se os pinos de fibras de carbono e de fibras de vidro. Consideraram também que pinos ativos estão obsoletos (predispõem à fratura da raiz), devendo ser dada preferência a pinos passivos, que podem ser classificados em: metálicos, cerâmicos ou de resinas reforçadas por fibras. Estes últimos proporcionam absorção de cargas funcionais de forma similar ao dente íntegro, 
devido a suas características mecânicas próximas à dentina. Os insucessos com estes pinos de fibras estão relacionados a falhas de cimentação ou à utilização em dentes com menos de $2 \mathrm{~mm}$ de remanescente coronário. Modificações estéticas de pinos de carbono levaram à produção de pinos com núcleo de carbono revestido por fibras de quartzo ou vidro. Os pinos de fibras de vidro ou quartzo possuem propriedades mecânicas e comportamento clínico similar aos pinos de fibras de carbono, além de melhor estética. Permitem a refração e transmissão da luz, tornando os opacificadores desnecessários. Existem ainda pinos de fibras de quartzo translúcidos, na tentativa de facilitar a polimerização de adesivos e cimentos resinosos no conduto. Recomendaram cimentos resinosos para cimentação de pinos de fibras, pois apresentam resistência adequada mesmo em camadas espessas, já que pinos pré-fabricados não se adaptam precisamente ao conduto. Sistemas adesivos de três passos são os mais indicados, pois não possuem acidez elevada (como adesivos convencionais de dois passos ou autocondicionantes de passo único), não interferindo na polimerização de cimentos resinosos duais ou autopolimerizáveis.

MITSUI et al. ${ }^{84}$, em 2004, avaliaram a resistência à fratura de raízes de incisivos centrais bovinos restauradas com diferentes pinos intra-radiculares, distribuídos em cinco grupos (15 espécimes cada): 1) núcleo metálico fundido; 2) pino de titânio; 3) pino de fibras de carbono; 3) pino de fibras de vidro; e 5) pino de dióxido de zircônia. Executou-se a secção dos incisivos a $14 \mathrm{~mm}$ do ápice e prepararam-se os condutos até $9 \mathrm{~mm}$ de profundidade, com as brocas recomendadas pelos fabricantes. Após cimentação dos pinos com cimento resinoso e confecção da porção coronária com resina composta ( $3 \mathrm{~mm}$ de altura), fixaram-se as raízes em resina, mantendo $3 \mathrm{~mm}$ das raízes expostas. A seguir, submeteram-se as raízes à compressão em ângulo de $135^{\circ} \mathrm{com}$ o longo eixo da raiz, à velocidade de $0,5 \mathrm{~mm} / \mathrm{min}$. Raízes restauradas com pinos de titânio apresentaram maior resistência que as restauradas com pinos cerâmicos ou de fibras de vidro e similar àquela de pinos de fibras de carbono. A resistência de qualquer dos pinos pré-fabricados foi similar a dos núcleos metálicos fundidos.

COELHO SANTOS; EL-MOWAFY; RUBO ${ }^{20}$, em 2004, determinaram, através do teste de resistência à tração diametral, a influência de diferentes pinos sobre a resistência à fratura de uma resina composta para construção de núcleos de preenchimento. Prepararam-se sete grupos com 10 espécimes cilíndricos cada $(6 \mathrm{~mm}$ de diâmetro e $3 \mathrm{~mm}$ de altura), com a resina composta envolvendo diferentes pinos: 1) 
Vectripost (VTS) - fibras de vidro; 2) FibreKor (FKR) - fibras de vidro; 3) Aestheti-Plus (ATP) - fibras de quartzo; 4) Light-Post (LTP) - fibras de quartzo; 5) Dentorama (DRM) - fibras de vidro. Foram constituídos ainda dois grupos controle: um apenas de resina composta, e outro com resina envolvendo o pino de aço Para-Post (PRP). Armazenaram-se os espécimes por sete dias em água a $37^{\circ} \mathrm{C}$ antes de aplicar a compressão na máquina de ensaios, à velocidade de $0,5 \mathrm{~mm} / \mathrm{min}$. Examinaram-se os fragmentos de dois espécimes de cada grupo sob microscopia eletrônica de varredura (MEV) para determinar a natureza da falha. Obtiveram-se os seguintes valores: apenas resina - 5,06kgf; VTS - 3,03kgf; FKR - 3,25kgf; ATP - 2,94kgf; LTP - 3,49kgf; DRM - 3,41kgf; e PRP - 2,84kgf. A MEV indicou que para o PRP a falha foi do tipo adesiva, enquanto para todos os pinos não-metálicos houve predominância de falha coesiva do pino. A maior resistência à tração diametral foi obtida com espécimes apenas de resina. Nos espécimes de resina com pinos de fibras, os pinos LTP, DRM e FKR resultaram em valores significativamente mais altos que espécimes com os pinos VTS e ATP. A menor resistência foi obtida com o pino metálico. Concluiu-se que o uso de pinos não resultou em reforço da resina composta.

USUMEZ et al. ${ }^{135}$, em 2004, ressaltaram que a cimentação adesiva pode ser importante tanto para a retenção adequada de pinos intra-radiculares, quanto para que seja atingido um dos objetivos mais almejados na restauração de dentes despolpados, que é o seu reforço. Compararam a microinfiltração entre pinos estéticos cimentados com cimento resinoso dual e um pino metálico cimentado com policarboxilato de zinco, visando verificar a capacidade de selamento e adesão destes pinos. Trataram endodonticamente 40 dentes unirradiculares, que tiveram as coroas removidas e foram divididos em quatro grupos iguais: 1) pino de aço inoxidável; 2) pino de fibras de vidro; 3 ) pino de fibras de polietileno (confecção diretamente no conduto); 4) pino de zircônia. Um dente sem pino foi o controle positivo. A microinfiltração foi medida sete dias, três meses e seis meses após a cimentação dos pinos. Houve diferença significativa na infiltração entre os quatro pinos. A capacidade de selamento do pino de zircônia diminuiu com o tempo (tornando-se inaceitável), e para pinos de polietileno e de aço permaneceu constante. Já com pinos de fibras de vidro aumentou até três meses e depois estabilizou. Não houve diferença significativa entre pinos de fibras de polietileno ou de vidro em nenhum período analisado, e estes pinos mostraram menor infiltração que pinos metálicos e de zircônia em todos os períodos. 
YOLDAS; TAYFUN ${ }^{139}$, em 2005, avaliaram a profundidade de polimerização da resina composta utilizando-se: 1) pinos fototransmissores Luminex; 2) pinos de fibras de vidro convencionais Postec; ou 3) apenas fotopolimerização convencional (grupo controle). Ambos os pinos possuíam 1,5mm de diâmetro. A resina composta foi condensada em condutos artificiais de $15 \mathrm{~mm}$ de comprimento e $4 \mathrm{~mm}$ de diâmetro, feitos em 30 cilindros plásticos negros (divididos em três grupos iguais). 0 tempo de fotopolimerização foi sempre de 90 segundos. Vinte e quatro horas após a polimerização, removeram-se os cilindros plásticos e executou-se o teste de microdureza superficial nas profundidades de $2 \mathrm{~mm}, 4 \mathrm{~mm}, 6 \mathrm{~mm}, 8 \mathrm{~mm}, 10 \mathrm{~mm}, 12 \mathrm{~mm}$ e $14 \mathrm{~mm}$. Houve aumento significativo na microdureza da resina com os pinos fototransmissores ou pinos de fibras de vidro convencionais em relação ao grupo controle. Não houve diferença significativa na microdureza entre pinos de fibras de vidro e pinos fototransmissores até $10 \mathrm{~mm}$; a partir desse ponto, a microdureza foi maior com pinos fototransmissores. A microdureza decresceu com o aumento da distância da ponta fotopolimerizadora nos três grupos.

O trabalho de BRAZ et al. ${ }^{16}$, em 2005, avaliou a resistência flexural de pinos de fibras de vidro combinados com materiais de preenchimento utilizados para reforço radicular, bem como a resistência à fratura de raízes alargadas reforçadas com os mesmos materiais. Para o teste de resistência flexural, confeccionaram-se 10 cilindros (3,5mm de diâmetro e $14 \mathrm{~mm}$ de comprimento) em cada grupo: 1) pino de fibras de vidro Reforpost e cimento resinoso dual Variolink II; 2) pino Reforpost e resina composta dual para núcleos de preenchimento BisCore; 3 ) pino Reforpost e três pinos acessórios Reforpin com cimento Variolink II. Após armazenamento em ambiente seco por 24 horas, submeteram-se os cilindros à carga na máquina de ensaios, na velocidade de $0,5 \mathrm{~mm} / \mathrm{min}$. As médias de resistência flexural foram (em MPa): grupo 1 - 206,52; grupo 2 - 224,39; e grupo 3 - 272,64. A resistência flexural do grupo 3 foi significativamente maior que a dos outros grupos. Para o teste de resistência à fratura, removeram-se as coroas de 30 caninos superiores despolpados ao nível da junção cemento-esmalte e alargaram-se os condutos até $3,5 \mathrm{~mm}$ de diâmetro, simulando canais alargados. Aplicou-se o sistema adesivo dual Excite DSC nas raízes, que foram divididas em três grupos, nos quais utilizaram-se os mesmos materiais que no teste de resistência flexural. A porção coronária do núcleo foi construída com resina composta e fixaram-se as raízes com resina acrílica em cilindros metálicos. Após armazenamento por 24 horas, aplicou-se a carga nos espécimes em ângulo de $135^{\circ}$ com o longo eixo da raiz, na velocidade de $0,5 \mathrm{~mm} / \mathrm{min}$. 
Os valores médios de resistência à fratura foram (em kgf): grupo 1 - 47,45; grupo 2 66,57 ; e grupo $3-74,11$. A média do grupo 1 foi significativamente menor que a dos demais grupos. Concluiu-se que o pino de fibras, combinado com pinos acessórios, é o método de escolha para reforçar raízes debilitadas.

GALHANO et al. $^{43}$, em 2005, investigaram a resistência à flexão de diferentes pinos de fibras, distribuídos em oito grupos (10 espécimes cada): 1) pino de fibras de carbono C-Post; 2) pino de fibras de carbono-quarzo Aestheti-Post; 3) pino de fibras de quartzo Aestheti-Plus; 4) pino de fibras de quartzo Light-Post; 5) pino de fibras de quartzo D. T. Light-Post; 6) pino de fibras de vidro ParaPost FiberWhite; 7) pino de fibras de vidro FibreKor; 8) pino de fibras de vidro Reforpost. Executou-se o teste de flexão dos três pontos, à velocidade de $1 \mathrm{~mm} / \mathrm{min}$. Os valores médios obtidos para pinos Aestheti-Post e Aestheti-Plus foram mais altos (estatisticamente similares) que os dos demais grupos. Os valores médios obtidos com os pinos C-Post, LightPost, D. T. Light Post, ParaPost FiberWhite e FibreKor foram similares entre si e mais altos que os obtidos com pinos Reforpost, que atingiram os valores mais baixos.

GORACCl et al. ${ }^{47}$, em 2005, mensuraram a adesão entre os pinos translúcidos de fibras de vidro FRC Postec (FRC) e de fibras de quartzo Light-Post (LP) com duas resinas compostas de baixa viscosidade usadas para confecção de núcleos de preenchimento: UnifilFlow (UF) e Tetric Flow (TF), com ou sem aplicação do silano Monobond-S (S) sobre o pino. Quando aplicado, o silano permaneceu por um minuto sobre o pino.Os grupos experimentais foram: 1.1) FRC + UF; 1.2) FRC + $S$ + UF; 1.3) FRC + TF; 1.4) FRC + S + TF; 2.1) LP + UF; 2.2) LP + S + TF; 2.3) LP + TF; 2.4) LP + S + TF. A seguir, obtiveram-se barras em todos os grupos, acrescentando resina em torno dos pinos, no interior de matrizes cilíndricas. Seccionaram-se as barras, gerando 30 a 35 espécimes de $1 \mathrm{~mm}$ de espessura. A resistência adesiva na interface pino-resina foi medida com uma técnica de micro-tração, à velocidade de $0,5 \mathrm{~mm} / \mathrm{min}$. A Tabela 2.4 apresenta os resultados encontrados. Todas as falhas foram do tipo adesivas na interface pino-resina. A silanização do pino antes da aplicação da resina composta aumentou significativamente a adesão entre pino e resina, em todas as combinações testadas. 
TABELA 2.4 - Resistência adesiva com oito combinações de pinos de fibras e de resinas compostas de baixa viscosidade, com ou sem aplicação de silano sobre o pino (GORACCl et al., 2005)

\begin{tabular}{c|c|c|c|c|c|c|c|c} 
Grupos & FRC+UF & FRC+S+UF & FRC+TF & FRC+S+TF & LP+UF & LP+S+UF & LP+TF & LP+S+TF \\
\hline Média & & & & & & & & \\
$\mathbf{( M P a})$ & 9,05 & 11,11 & 10,74 & 12,88 & 8,36 & 12,22 & 7,87 & 13,43
\end{tabular}

NAUMANN; BLANKENSTEIN; DIETRICH ${ }^{91}$, em 2005, avaliaram o desempenho clínico de dentes tratados endodonticamente e restaurados com pinos de fibras de vidro. Faziam parte da amostra dentes com graus variados de perda de estrutura dentária, sendo que a maioria não possuía nenhum remanescente coronário e em muitos a embocadura do conduto estava excessivamente alargada. Confeccionaram-se coroas totais ou próteses fixas em $79 \%$ dos casos. Foram restaurados 105 dentes com 51 pinos de fibra de vidro Luscent Anchors cônicos (40 pacientes) e 54 pinos FibreKor (43 pacientes), com diâmetro de 1,00mm, 1,25mm ou $1,5 \mathrm{~mm}$, de acordo com o diâmetro do conduto. Cada paciente recebeu apenas um tipo de pino. No grupo com Luscent Anchors, havia maior número de pacientes com atrição, maior número de dentes com coroas totais ou próteses fixas, bem como maior número de dentes com mobilidade. Executou-se a cimentação com sistema adesivo EBS-Multi e cimento resinoso dual Compolute; para reconstrução coronária utilizou-se resina composta Clearfil Core. Todas as restaurações foram observadas por 24 meses. Após 12 meses, 3,8\% das restaurações falharam. Não houve nenhum caso de deslocamento do pino e apenas dois pinos fraturaram. Uma fratura não-restaurável ocorreu na raiz mesial de um molar inferior (o pino foi cimentado na raiz distal). Após 24 meses, $11,4 \%$ das restaurações falharam. Dois pinos deslocaram, sete pinos fraturaram, uma raiz fraturou de forma não-reparável e houve falha adesiva da porção coronária de um núcleo. Doze das 16 falhas ocorridas em 24 meses foram em dentes sem nenhum remanescente coronário. Não houve diferença significativa entre os dois tipos de pinos em relação ao número de falhas durante dois anos de serviço clínico.

GORACCI et al. $^{48}$, em 2005, avaliaram o grau de influência dos adesivos dentinários sobre a retenção de pinos de fibras. Após tratamento endodôntico de 36 dentes unirradiculares com coroas removidas, o terço cervical e médio dos canais foram desobturados e preparados conforme instruções dos 
fabricantes dos pinos. Utilizaram-se pinos de fibras de vidro cônicos ( $1 \mathrm{~mm}$ de diâmetro apical), silanizados antes da cimentação e distribuídos em dois grupos iguais: 1) cimento autopolimerizável Panavia 21; e 2) cimento dual Variolink II. Dividiu-se cada grupo em dois subgrupos iguais, de acordo com a utilização ou não do adesivo. No sub-grupo $1 \mathrm{~A}$, cimentou-se o pino apenas com o cimento, e no sub-grupo 1B aplicouse previamente $o$ adesivo (ED Primer). No sub-grupo $2 A$, somente o cimento foi utilizado, e no sub-grupo 2B, associou-se o a adesivo (Excite DSC) ao cimento. Após armazenamento em água destilada por 24 horas, seccionaram-se as raízes transversalmente em quatro a seis fatias ( $1 \mathrm{~mm}$ de espessura) e executou-se o teste de resistência à extrusão (push-out) até deslocamento do pino. Avaliou-se a infiltração ao longo da interface cimento-dentina com microscopia eletrônica de transmissão. Para ambos os cimentos, não houve diferença significativa na retenção com ou sem aplicação de adesivo. Com a combinação Panavia 21 - ED Primer, a lama dentinária foi apenas parcialmente dissolvida e estava dispersa ao longo da interface cimentodentina. Além disso, a camada híbrida não era evidente. Com a associação Variolink II - Excite DSC, a camada híbrida também não era uniforme ao longo de todo o conduto. Uma vez que a utilização de adesivos não aumentou a retenção e devido à dificuldade de obtenção de camadas híbridas contínuas, deve-se considerar que, similarmente ao que ocorre com cimentos não adesivos, a fricção possui um papel importante na resistência ao deslocamento de pinos intra-radiculares.

MONTICELLI et al. ${ }^{88}$, em 2006, avaliaram a influência de várias combinações de sistemas adesivos e agentes cimentantes sobre a resistência adesiva de pinos de fibras ao canal radicular. Trinta pré-molares tratados endodonticamente, com a coroa removida e o conduto preparado para cimentação de pinos de fibras de vidro (FRC Postec) foram distribuídos em seis grupos, de acordo com a combinação agente cimentante-sistema adesivo utilizada: 1A) cimento resinoso autopolimerizável Multilink (ML) e sistema adesivo Multilink Primer; 2A) cimento ML e adesivo Clearfil Photo Bond; $3 \mathrm{~A}$ ) cimento $\mathrm{ML}$ e adesivo Clearfil Newbond; 1B) resina composta fotopolimerizável Clearfil Photo Core (CPC) e adesivo Multilink Primer; 2B) resina CPC e adesivo Clearfil Photo Bond; 3B) resina CPC e adesivo Clearfil Newbond. Os adesivos Clearfil Photo Bond (cura dual) e Clearfil New Bond (autopolimerizável) requerem condicionamento ácido; já o adesivo Multilink Primer é autocondicionante e autopolimerizável (primer A misturado com o primer B e aplicado diretamente sobre a lama dentinária). Após armazenamento em água deionizada por 24 horas, os dentes foram seccionados, obtendo-se barras com $1 \mathrm{~mm}^{2}$ de diâmetro. Estes espécimes foram 
submetidos ao teste de micro-tração na máquina de ensaios, à velocidade de $0,5 \mathrm{~mm} / \mathrm{min}$ e avaliados em estereomicroscópio para classificar o modo de falha como adesivo (na interface cimento-pino ou cimento-dentina), coesivo (no cimento ou dentina) ou misto. A análise estatística revelou que os sistemas adesivos, os materiais cimentantes e a interação entre estes dois fatores influenciaram significativamente a resistência adesiva. Quando foi usada a resina CPC para cimentação, todos os adesivos funcionaram de forma similar. O cimento ML mostrou melhor adesão se combinado com seu adesivo próprio, o Multilink Primer (maior valor numérico dos seis grupos), que quando associado aos outros adesivos. Nos seis grupos, a maioria das falhas foi na interface adesivo-dentina. Com o adesivo Clearfil Photo Bond (cura dual), não houve interação química desfavorável com nenhum dos agentes cimentantes, enquanto com o Clearfil New Bond (autopolimerizável), a resistência adesiva foi reduzida quando associado ao cimento resinoso autopolimerizável ML.

NAUMANN; PREUSS; ROSENTRITT ${ }^{90}$, em 2006, compararam a resistência à fratura de dentes endodonticamente tratados e com férulas incompletas da coroa. Devido a situações como sobre-carga oclusal, injúria traumática e processos cariosos, é comum ser impossível a obtenção de abraçamento de tecido dental sadio em toda a circunferência da coroa, caracterizando uma férula incompleta. Distribuíramse 40 incisivos centrais superiores em 4 grupos (10 dentes cada): 1) férula completa $\left(360^{\circ}\right) \mathrm{c} / 2 \mathrm{~mm}$ de altura: 2) férula de $2 \mathrm{~mm}$ interrompida na face vestibular; 3 ) férula de $2 \mathrm{~mm}$ interrompida na face lingual; 4) férula de $2 \mathrm{~mm}$ interrompida nas faces proximais. Após o preparo dos condutos com $8 \mathrm{~mm}$ de profundidade, cimentaram-se pinos de fibras de vidro (Fibrepoints Root Pins Glass) nos condutos com um cimento resinoso (RelyX Unicem) e confeccionou-se a porção coronária dos núcleos com resina composta (Clearfil Core). Coroas de cerâmica pura (Empress II) foram cimentadas sobre os núcleos com o mesmo cimento. Após a fixação em blocos de resina acrílica, oito espécimes de cada grupo foram expostos à ciclagem térmica (6.000 ciclos entre 5 e $55^{\circ} \mathrm{C}, 2$ minutos cada ciclo) e à carga dinâmica (1,2 milhões de ciclos, equivalendo a 5 anos de mastigação, força de $50 \mathrm{~N}$ ) em ângulo de $135^{\circ}$ com o longo eixo da raiz. Os espécimes sobreviventes (sete dos grupos 2 e 3, cinco do grupo 4 e todos os do grupo 1) foram submetidos à carga estática na máquina de ensaios, à velocidade de $1 \mathrm{~mm} / \mathrm{min}$. A maior resistência $(91,67 \mathrm{kgf}$ ) foi obtida para o grupo 3 (ausência de férula na face lingual). Com a ausência de férula na face vestibular (grupo 2), a resistência foi de $67,09 \mathrm{kgf}$ e a férula completa (grupo 1) alcançou 51,18kgf. O menor valor $(36,70 \mathrm{kgf})$ foi visto com a ausência de férula nas proximais (grupo 4). A análise 
estatística revelou diferença significativa entre todos os grupos, exceto entre os grupos 1 e 4 , e entre os grupos 2 e 4 . Dois espécimes de cada grupo foram submetidos somente à carga estática, apresentando valores similares àqueles submetidos à carga dinâmica. O tipo de fratura mais freqüente foi a fratura oblíqua estendendo-se da margem cervical da face lingual da raiz até o $1 / 3$ médio da face vestibular da raiz (fratura desfavorável à reabilitação dentária). Os autores concluíram que apesar dos altos valores de resistência, uma férula incompleta está associada com uma maior propensão à fratura dentária e com maior variação na resistência à fratura.

Em 2006, VANO et al. ${ }^{136}$ avaliaram a influência de vários tratamentos superficiais sobre a resistência adesiva de diferentes resinas compostas a pinos de fibras. Dividiram-se 110 pinos de fibras de vidro GC Fibre Post em cinco grupos (22 dentes cada), variando o tratamento de superfície: 1) imersão em peróxido de hidrogênio $\left(\mathrm{H}_{2} \mathrm{O}_{2}\right)$ a $24 \%$ por 10 min. e silanização por 60seg.; 2) imersão em $\mathrm{H}_{2} \mathrm{O}_{2}$ a $10 \%$ por 20 min. e silanização por 60 seg.; 3) imersão em ácido hidrofluorídrico por 60 seg. e silanização por 60 seg.; 4) silanização por 60 seg. e aplicação do agente adesivo G-Bond; 5) silanização por 60 seg. (controle). Após o tratamento, a morfologia superficial de dois pinos de cada grupo foi avaliada com microscopia eletrônica de varredura. Distribuíram-se os pinos remanescentes de cada grupo em cinco subgrupos (cinco pinos cada), de acordo com a resina composta usada: duas resinas compostas de baixa viscosidade, Unifil Flow (subgrupo A) e Unifil Lo Flo Plus (subgrupo B), resina composta híbrida Gradia Direct (subgrupo C) e resina composta para núcleos de preenchimento Unifil Core. Após a confecção de cilindros de resina composta com o pino no centro, estes foram seccionados em máquina de corte para obtenção de barras retangulares de $1 \mathrm{~mm}$ de espessura, que foram submetidas ao ensaio de microtração. A resistência adesiva entre $o$ pino $e$ as resinas compostas foi significativamente maior nos grupos 1 e 2, e a resistência adesiva no grupo controle foi significativamente menor que nos demais grupos. Nos grupos 1 e 2, a resistência adesiva foi similar, independentemente da resina utilizada. Tanto o peróxido de hidrogênio quanto o ácido hidrofluorídrico modificaram a morfologia de superfície dos pinos de fibras, aumentando a área para adesão e o embricamento mecânico entre a resina e o pino. Ambos os agentes dissolveram superficialmente a matriz resinosa dos pinos, embora esta fosse à base de metacrilato, e não uma resina epóxica, como na maioria dos pinos de fibras. O peróxido de hidrogênio produziu uma distribuição uniforme de micro-espaços e não danificou as fibras ou a matriz resinosa. Com o ácido hidrofluorídrico, a remoção da matriz foi mais profunda, a distribuição de micro- 
espaços foi irregular e algumas fibras foram danificadas. O silano funcionou como um agente de ligação química entre as fibras de vidro expostas e a matriz da resina, aumentando a resistência adesiva entre pinos de fibra e resinas compostas. 
3 PROPOSIÇÃO 


\section{PROPOSIÇÃO}

Diante da necessidade de desenvolverem-se técnicas capazes de restaurar adequadamente raízes com condutos alargados, bem como da investigação das propriedades mecânicas destas raízes quando reconstruídas com pinos de fibras de vidro, a presente pesquisa teve como objetivos:

3.1. Avaliar a resistência à fratura de dentes tratados endodonticamente com condutos medianamente alargados, reconstruídos com diferentes sistemas de núcleos;

3.2. Avaliar o padrão de fratura ocorrido nestes dentes, quando submetidos à carga compressiva oblíqua $\left(135^{\circ}\right.$ com o longo eixo da raiz). 
4 MATERIAL E MÉTODOS 


\section{MATERIAL E MÉTODOS}

\subsection{Material}

Para a realização desta pesquisa foi utilizado o material descrito na

Figura 4.1.

\begin{tabular}{|c|c|c|}
\hline MATERIAL & NOME COMERCIAL & FABRICANTE \\
\hline $\begin{array}{l}\text { Ácido etileno diamino } \\
\text { tetracético }\end{array}$ & EDTA trissódico $24 \%$ & $\begin{array}{l}\text { Biodinâmica Química e } \\
\text { Farmacêutica Ltda., Ibiporã } \\
\text { - PR }\end{array}$ \\
\hline $\begin{array}{l}\text { Ácido fosfórico a 37\% em } \\
\text { gel }\end{array}$ & Ácido fosfórico Dentsply & $\begin{array}{l}\text { Dentsply Ind. e Com., Rio de } \\
\text { Janeiro - RJ }\end{array}$ \\
\hline Agente silano & $\begin{array}{lr}\text { Scotchbond } & \text { Ceramic } \\
\text { Primer, 3M ESPE, St. Paul, } \\
\text { MN, USA }\end{array}$ & $\begin{array}{l}\text { 3M ESPE, St. Paul, MN, } \\
\text { USA }\end{array}$ \\
\hline Aparelho fotopolimerizador & Fotopolimerizador XL1500 & $\begin{array}{l}\text { 3M ESPE, St. Paul, MN, } \\
\text { USA }\end{array}$ \\
\hline Brocas de Largo $n^{\circ} 1$ a 4 & & Dentsply / Maillefer - Swiss \\
\hline $\begin{array}{l}\text { Brocas esféricas de } \\
\text { carboneto de tungstênio } \\
\text { (carbide) } n^{\circ} 2\end{array}$ & & $\begin{array}{l}\text { S.S. White } \quad \text { Artigos } \\
\text { Odontológicos - Rio de } \\
\text { Janeiro-RJ }\end{array}$ \\
\hline Cera azul para incrustações & Cera Kerr & $\begin{array}{l}\text { Kerr Ind. e Com. Ltda., São } \\
\text { Paulo - SP }\end{array}$ \\
\hline $\begin{array}{l}\text { Cimento de ionômero de } \\
\text { vidro modificado por resina }\end{array}$ & RelyX Luting & $\begin{array}{l}\text { 3M ESPE, St. Paul, MN, } \\
\text { USA }\end{array}$ \\
\hline $\begin{array}{l}\text { Cimento resinoso de cura } \\
\text { dual }\end{array}$ & RelyX CRA & $\begin{array}{l}\text { 3M ESPE, St. Paul, MN, } \\
\text { USA }\end{array}$ \\
\hline $\begin{array}{l}\text { Cones de guta-percha } \\
\text { calibrados }\end{array}$ & Tanari & $\begin{array}{l}\text { Tamariman Industrial Ltda., } \\
\text { Macaçaruru - AM }\end{array}$ \\
\hline Delineador & Delineador Bio-Art & 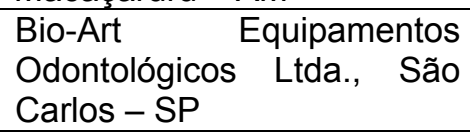 \\
\hline \multicolumn{3}{|l|}{ Dentes caninos humanos } \\
\hline Espessímetro & Espessímetro Otto & $\begin{array}{l}\text { Arminger e Cia. Ltda, São } \\
\text { Leopoldo - RS }\end{array}$ \\
\hline $\begin{array}{l}\text { Fitas de fibras de vidro pré- } \\
\text { impregnadas com resina } \\
\text { composta }\end{array}$ & Interlig & $\begin{array}{l}\text { Odonto-Lógika Ind. de Prod. } \\
\text { Odontológicos } \\
\text { Londrina-PA }\end{array}$ \\
\hline Gesso especial & Durone & $\begin{array}{l}\text { Dentsply Ind. e Com., Rio de } \\
\text { Janeiro - RJ }\end{array}$ \\
\hline Hipoclorito de sódio a $0,5 \%$ & Solução de Dakin & $\begin{array}{l}\text { Biodinâmica } \quad \text { Química e } \\
\text { Farmacêutica } \\
\text { - Ptda., Ibiporã }\end{array}$ \\
\hline
\end{tabular}

(Continua) 
(Continuação da Figura 4.1)

\begin{tabular}{|c|c|c|}
\hline Liga de Níquel-Cromo & Dan Ceramalloy & $\begin{array}{l}\text { Nihon Kinzoku Co., Osaka, } \\
\text { Japan }\end{array}$ \\
\hline $\begin{array}{l}\text { Limas de aço inoxidável } n^{\circ} \\
15 \text { a } 60\end{array}$ & K-flex & Sybrion / Kerr, Basel - Swiss \\
\hline Lubrificante à base de água & K-Y Gel & $\begin{array}{l}\text { Johnson \& Johnson Comércio } \\
\text { e Distribuição Ltda., São Paulo } \\
\text { - SP }\end{array}$ \\
\hline $\begin{array}{l}\text { Lupa frontal de quatro } \\
\text { aumentos }\end{array}$ & Lupa Bio-Art 4x & $\begin{array}{lc}\text { Bio-Art } & \text { Equipamentos } \\
\text { Odontológicos } & \text { Ltda., São } \\
\text { Carlos - SP } & \\
\end{array}$ \\
\hline Máquina de ensaios universal & Modelo K-2000 MP & $\begin{array}{l}\text { Dinamômetros Kratos Ltda., } \\
\text { São Paulo - SP }\end{array}$ \\
\hline $\begin{array}{l}\text { Pinos acessórios de fibras de } \\
\text { vidro (micro-pinos) }\end{array}$ & Reforpin $n^{\circ} 1,2$ e 3 & $\begin{array}{l}\text { Odonto-Lógika Ind. de Prod. } \\
\text { Odontológicos Ltda, Londrina - } \\
\text { PA }\end{array}$ \\
\hline $\begin{array}{l}\text { Pinos de fibras de vidro } \\
\text { convencionais }\end{array}$ & FibreKor $n^{\circ} 2$ & $\begin{array}{l}\text { Pentron Corporation, } \\
\text { Wallingford, Connecticut - USA }\end{array}$ \\
\hline Plastificador a vácuo & Plastivac & $\begin{array}{l}\text { Bio-Art Equipamentos } \\
\text { Odontológicos Ltda., São } \\
\text { Carlos - SP }\end{array}$ \\
\hline Ponta aplicadora & Microbrush & $\begin{array}{l}\text { Microbrush Corporation, } \\
\text { Grafton - USA }\end{array}$ \\
\hline Pontas de papel absorvente & Tanari & $\begin{array}{l}\text { Tamariman Industrial Ltda., } \\
\text { Macaçaruru - AM }\end{array}$ \\
\hline $\begin{array}{l}\text { Pontas diamantadas } \mathrm{n}^{\circ} \\
1016 \mathrm{HL}, 3017 \mathrm{HL}, 3195,3216 \\
\text { e } 4138\end{array}$ & & $\begin{array}{l}\text { KG Sorensen Ind. e Com. } \\
\text { Ltda., São Paulo - SP }\end{array}$ \\
\hline Pontas para seringa Centrix & Pontas Centrix & Centrix Inc., Milford - USA \\
\hline $\begin{array}{l}\text { Resina acrílica } \\
\text { autopolimerizável }\end{array}$ & Clássico & $\begin{array}{l}\text { Clássico Artigos Odontológicos } \\
\text { S/A - Brasil }\end{array}$ \\
\hline $\begin{array}{l}\text { Resina acrílica } \\
\text { autopolimerizável }\end{array}$ & Duralay & $\begin{array}{l}\text { Reliance Dental Manufactaring } \\
\text { Co., Worth, Illinois - USA }\end{array}$ \\
\hline $\begin{array}{l}\text { Resina composta de baixa } \\
\text { viscosidade (flow) }\end{array}$ & Filtek Flow cor A2 & 3M ESPE, St. Paul, MN, USA \\
\hline $\begin{array}{l}\text { Resina composta para } \\
\text { núcleos de preenchimento }\end{array}$ & Enforce-Core & $\begin{array}{l}\text { Dentsply Ind. e Com., } \\
\text { Petrópolis,Rio de Janeiro }\end{array}$ \\
\hline Revestimento fosfatado & Heat Shock & $\begin{array}{l}\text { Polidental Ind. Bras., São } \\
\text { Paulo - SP }\end{array}$ \\
\hline $\begin{array}{l}\text { Seringa para inserção de } \\
\text { materiais plásticos }\end{array}$ & Centrix & Centrix Inc., Milford - USA \\
\hline Silicona de condensação & $\begin{array}{l}\text { Zetalabor Extra-Hard / } \\
\text { Ruthinium Activator }\end{array}$ & $\begin{array}{l}\text { Zhermack S. A., Badia } \\
\text { Polesine, Rovigo - Itália }\end{array}$ \\
\hline Sistema adesivo & $\begin{array}{l}\text { Scotchbond Multi-Uso Plus } \\
\text { (Primer, Ativador, } \\
\text { Catalisador e Adesivo) }\end{array}$ & 3M ESPE, St. Paul, MN, USA \\
\hline $\begin{array}{l}\text { Solução evidenciadora de } \\
\text { contatos }\end{array}$ & Arti-Spot 2 & $\begin{array}{l}\text { Bausch Articulating Papers } \\
\text { Inc., Nashua - USA }\end{array}$ \\
\hline Sonda exploradora $\mathrm{n}^{\circ} 5$ & & $\begin{array}{l}\text { Duflex / S.S. White Artigos } \\
\text { Odontológicos - Rio de } \\
\text { Janeiro - RJ }\end{array}$ \\
\hline
\end{tabular}

FIGURA 4.1 - Relação do material utilizado na pesquisa e dos fabricantes 


\subsection{Métodos}

\subsubsection{Seleção dos dentes}

Para realização deste estudo, utilizou-se uma amostra de 50 dentes caninos humanos superiores e inferiores, com dimensões similares e livres de qualquer tipo de lesão cervical (cárie, erosão ou abrasão), defeitos nas raízes ou tratamento endodôntico prévio. Estes dentes foram esterilizados em autoclave a $121^{\circ} \mathrm{C}$ por 30 minutos. Antes e durante o experimento, os dentes foram armazenados em condições úmidas (solução fisiológica), prevenindo sua desidratação, e seu manuseio foi sempre feito com gaze úmida.

Os dentes foram aleatoriamente distribuídos em cinco grupos com 10 espécimes cada, onde os seguintes materiais foram utilizados para reconstrução:

- Grupo 1 (grupo controle): núcleo metálico fundido totalmente adaptado ao conduto radicular;

- Grupo 2: pino de fibras de vidro de diâmetro menor que o do conduto, envolvido apenas por cimento resinoso;

- Grupo 3: pino de fibras de vidro de diâmetro menor que o do conduto, envolvido por fitas de fibras de vidro;

- Grupo 4: pino de fibras de vidro de diâmetro menor que o do conduto, combinado com pinos de fibras de vidro acessórios;

- Grupo 5: pino de fibras de vidro de diâmetro menor que o do conduto, reembasado com resina composta de baixa viscosidade (pino anatômico).

Os cinco grupos experimentais encontram-se esquematicamente representados na Figura 4.2. 


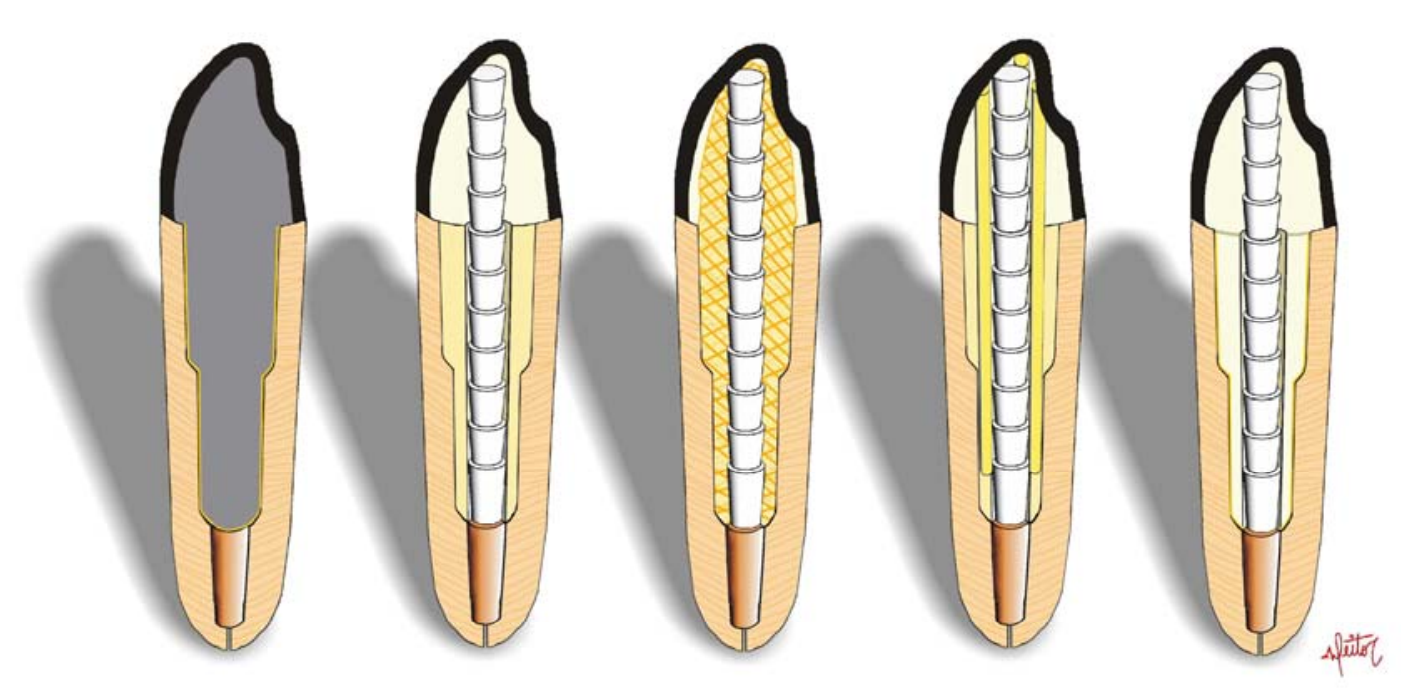

$\begin{array}{lllll}\text { GROUP 1] GROUP 2 } & \text { GROUP 3) GROUP 4 GROUP } 5\end{array}$

FIGURA 4.2 - Representação esquemática dos cinco grupos experimentais

\subsubsection{Procedimentos prévios}

\section{a. Tratamento endodôntico}

A abertura da câmara coronária para terapia endodôntica foi executada da forma convencional. Para a instrumentação endodôntica, utilizaram-se limas de aço inoxidável tipo Kerr e abundante irrigação com hipoclorito de sódio a 0,5\% (líquido de Dakin). Para a secagem dos condutos, foram utilizadas pontas de papel absorvente.

Os condutos foram preparados no limite de $1 \mathrm{~mm}$ aquém do ápice radicular, até a lima $n^{\circ} 60$ da $1^{\text {a }}$ série da International Standartization Organization (ISO) e obturados com cones de guta-percha de calibre correspondente e cimento endodôntico Sealer 26.

\section{b. Secção da porção coronária}

As coroas dos elementos dentários foram seccionadas com discos diamantados de dupla face, sob refrigeração com spray ar-água da seringa tríplice, ao nível da junção cemento-esmalte, de forma perpendicular ao longo eixo do dente e em 
plano reto. A superfície seccionada foi regularizada com pontas diamantadas $3216 \mathrm{e}$ 4138 em baixa-rotação.

Os remanescentes radiculares foram padronizados com comprimento médio de $15 \mathrm{~mm}$ e com um diâmetro de 5 a $5,5 \mathrm{~mm}$ no sentido mésio-distal e de 7 a $7,5 \mathrm{~mm}$ no sentido vestíbulo-palatino, por meio de um espessímetro e de um compasso.

\section{c. Fixação das raízes em cilindros plásticos}

As raízes foram fixadas em cilindros ocos de PVC com $25 \mathrm{~mm}$ de diâmetro e $30 \mathrm{~mm}$ de altura, utilizando-se resina acrílica autopolimerizável e mantendo-se uma altura de $3 \mathrm{~mm}$ de raiz exposta. Os dentes foram posicionados no interior dos cilindros em posição central e perpendicular à sua base, por meio de um delineador. Após a polimerização da resina, todos os cilindros foram numerados e mantidos em condições úmidas no interior de recipientes para armazenamento de filmes fotográficos.

\section{d. Preparo dos condutos radiculares}

O conduto radicular foi preparado até a profundidade de $10 \mathrm{~mm}$, controlando-se a penetração com cursores de borracha. Inicialmente, foram utilizados instrumentos aquecidos (pontas Rhein) para a desobturação, seguidos por brocas de Largo com diâmetros crescentes, até a de $n^{\circ} 4$ (que possui $1,3 \mathrm{~mm}$ de diâmetro), no contra-ângulo em baixa rotação.

A seguir, foi executado um preparo do conduto radicular de forma escalonada (com dois degraus), de forma a simular uma raiz com o conduto alargado (raiz debilitada). Para tal, foi utilizada a ponta diamantada $1016 \mathrm{HL}$, que possui diâmetro de $1,8 \mathrm{~mm}$, penetrando $10 \mathrm{~mm}$ no conduto (atingindo-se assim a profundidade total de preparo do conduto). A seguir, a ponta diamantada $3017 \mathrm{HL}$, que possui diâmetro de $2,5 \mathrm{~mm}$, penetrou $5 \mathrm{~mm}$ no conduto. Foi empregada uma sonda periodontal para controlar a profundidade de penetração das pontas diamantadas utilizadas para alargamento do conduto, bem como uma marca na haste destas pontas. 
A seqüência de preparo para os cinco grupos experimentais está esquematicamente representada na Figura 4.3. Uma vista incisal deste preparo pode ser observada na Figura 4.4.

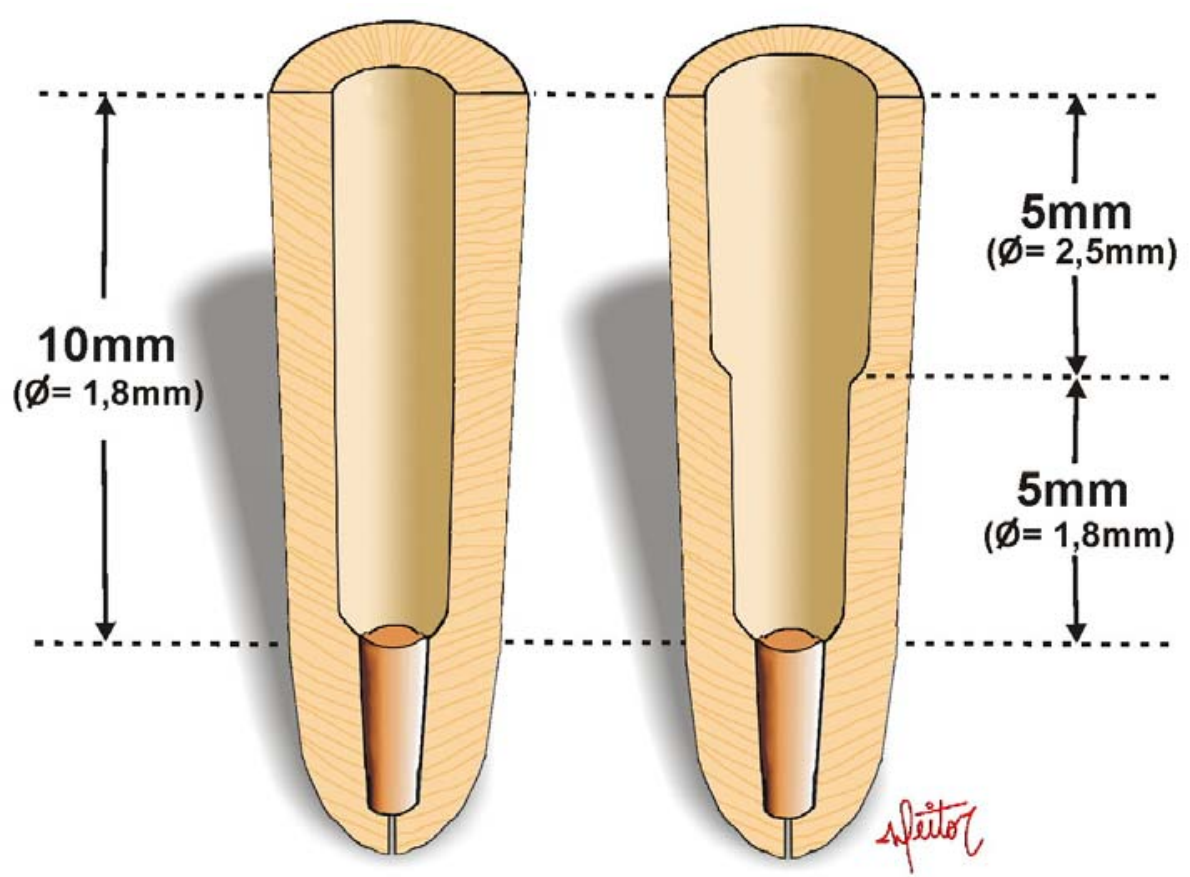

FIGURA 4.3 - Representação esquemática da seqüência de preparo

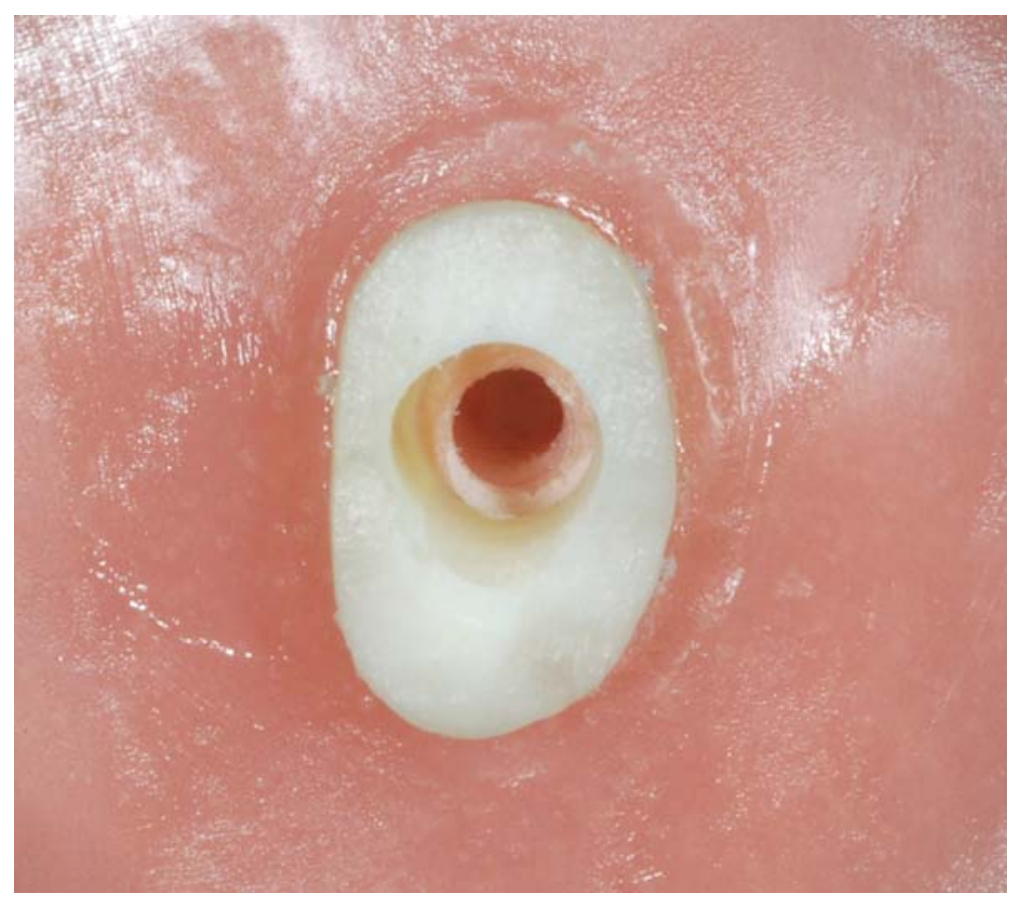

FIGURA 4.4 - Vista incisal do preparo do canal radicular utilizado para os cinco grupos 


\subsubsection{Preparo dos corpos de prova}

\section{a. Preparo dos corpos de prova do grupo 1}

Neste grupo, foram confeccionados 10 núcleos metálicos fundidos totalmente adaptados ao conduto radicular (grupo controle).

Os padrões dos núcleos foram obtidos a partir de modelagens dos condutos com resina acrílica autopolimerizável Duralay. Utilizando-se fresas de tungstênio, foram removidos os excessos, mantendo-se uma porção coronária de aproximadamente $2 \mathrm{~mm}$ de altura. Para a complementação da porção coronária dos núcleos, empregou-se a mesma resina acrílica, que foi utilizada para o preenchimento de matrizes fabricadas em laboratório, cuja função era padronizar a forma e dimensão da porção coronária dos núcleos.

Para obtenção das matrizes, inicialmente confeccionou-se o padrão de um núcleo em resina acrílica quimicamente ativada Duralay sobre um dos dentes preparados. Este padrão simulava a anatomia de um canino superior preparado para coroa total, com $6 \mathrm{~mm}$ de altura e chanfrado de aproximadamente $1,2 \mathrm{~mm}$ em todo o diâmetro do término cervical ${ }^{3}$. Este núcleo teve sua porção coronária moldada com silicona de condensação Zetalabor, obtendo-se 10 troquéis em gesso especial, que foram fixados em uma base de gesso-pedra e levados ao plastificador a vácuo para serem reproduzidos na forma de matrizes de polipropileno para confecção da porção coronária dos núcleos de preenchimento em todos os grupos.

A fundição dos núcleos foi executada em um laboratório comercial. Uma liga de Níquel-Cromo e um revestimento fosfatado foram utilizados para inclusão e fundição, seguindo-se as recomendações dos fabricantes para obtenção de núcleos metálicos fundidos com a técnica da cera perdida.

Ao serem recebidos do laboratório, os núcleos foram criteriosamente examinados com o auxílio de uma lupa frontal de quatro aumentos. Pequenos nódulos de fundição, quando presentes, foram removidos com brocas esféricas $n^{\circ} 2$ de carboneto de tungstênio em baixa rotação. Os núcleos foram avaliados quanto à adaptação e assentamento na base cervical com lupa e sonda exploradora. Em caso de adaptação insuficiente, o núcleo foi pincelado com uma fina camada de solução evidenciadora de contatos Arti-Spot 2 e, após secagem com leves jatos de ar, inserido 
no conduto. Nas áreas que impediram penetração completa do núcleo no conduto, a solução evidenciadora foi removida e pequenos ajustes destas áreas com brocas esféricas permitiram a obtenção de uma adaptação adequada em todos os espécimes.

Os condutos foram previamente limpos pelo seu preenchimento com EDTA a $24 \%$ em gel por 3 minutos, que foi agitado com lima tipo Kerr durante o terceiro minuto. Depois da lavagem com água destilada por um minuto, os condutos foram secos com cânula endodôntica e cones de papel absorvente.

O condicionamento ácido do conduto foi executado com gel de ácido fosfórico a $37 \%$ por 30 segundos, seguido por lavagem com água destilada em abundância pelo dobro do tempo e secagem com cânula endodôntica e cones de papel absorvente, tomando-se cuidado para não desidratar a dentina.

O sistema adesivo utilizado foi o Scotchbond Multi-Uso Plus na forma dual. Inicialmente, foi aplicado o ativador no conduto radicular utilizando uma ponta aplicadora Microbrush, secando-se com suaves jatos de ar por 3 segundos à distância de 5 a $6 \mathrm{~cm}$. A seguir, foram aplicados da mesma forma o primer e o catalisador do sistema, sucessivamente.

Previamente à cimentação, os núcleos foram submetidos a jatos de óxido de alumínio com partículas de $50 \mu$, lavados com água e secos. Sobre o núcleo foi aplicado o catalisador do sistema adesivo. Para sua cimentação, foi utilizado o cimento resinoso de polimerização dual RelyX CRA. Foram manipuladas quantidades iguais das pastas base e catalisadora do cimento até obtenção de mistura de cor uniforme. Uma pequena porção de cimento foi aplicada sobre o núcleo com pincel, bem como às paredes do conduto com broca lentulo em baixa rotação. O núcleo foi assentado com pressão digital e o conjunto levado à prensa estática, onde foi submetido a uma carga de $2 \mathrm{~kg}$. Neste momento, foi executada a fotopolimerização em torno do pino (40 segundos). Dez minutos após o assentamento do pino, o conjunto foi removido da prensa (Figura 4.5A e Figura 4.5B). 


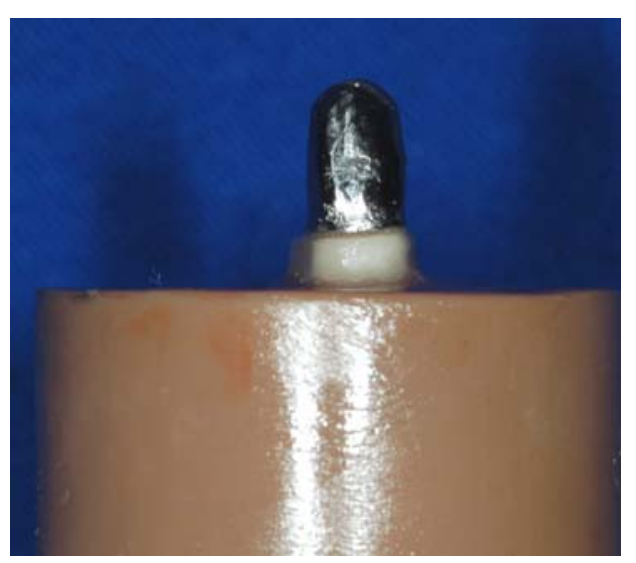

A

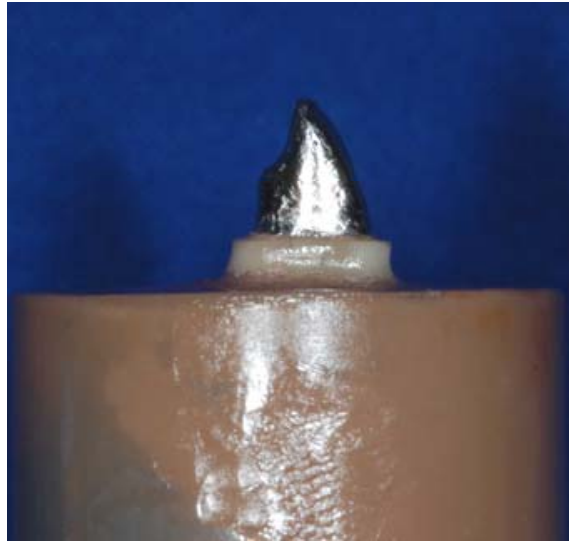

B

FIGURA 4.5 -Núcleo metálico fundido cimentado no canal radicular

A, Vista frontal

$B$, Vista lateral

\section{b. Preparo dos corpos de prova do grupo 2}

Neste grupo, foram confeccionados 10 núcleos de preenchimento utilizando o pino de fibras de vidro FibreKor $n^{\circ} 2$, com diâmetro de 1,25mm, circundado somente por cimento resinoso RelyX CRA. Estes pinos possuem forma cilíndrica e retenções mecânicas em toda sua extensão.

O pino de fibras de vidro foi reduzido no seu comprimento de forma que, quando inserido no conduto, permanecia uma altura de $5 \mathrm{~mm}$ acima da embocadura do conduto. Assim, como os pinos deveriam penetrar $10 \mathrm{~mm}$ no conduto, e uma vez que os pinos medem $20 \mathrm{~mm}$ de comprimento, todos os pinos foram cortados com $15 \mathrm{~mm}$ de comprimento, possibilitando a padronização do comprimento e do diâmetro dos pinos previamente à cimentação. Marcava-se a linha de corte do pino com uma caneta hidrográfica à distância de $15 \mathrm{~mm}$ do ápice do pino e então procedia-se ao corte com uma ponta diamantada 3216 sob irrigação abundante com spray ar-água. Provou-se o pino no conduto, verificando-se a adequação do comprimento com um compasso. Os condutos foram limpos da forma descrita para o grupo 1 e submetidos ao mesmo tratamento adesivo.

Após limpeza do pino de fibras de vidro com álcool etílico, aplicava-se sobre o mesmo uma camada de silano. Aguardava-se um minuto, secando-se então com suaves jatos de ar a distância de 5 a $6 \mathrm{~cm}$. A seguir, era aplicado no pino o catalisador do sistema adesivo Scotchbond Multi-Uso Plus. 
Para a cimentação do pino, foi utilizado também o cimento resinoso RelyX CRA, manipulado e utilizado da forma exposta anteriormente. Porém, o pino ficava imprecisamente adaptado ao conduto, por ser de menor diâmetro que aquele. Assim sendo, o pino era mantido em posição central no conduto e paralela ao longo eixo da raiz utilizando um delineador, enquanto era executada a fotopolimerização do cimento, por 40 segundos em cada face. Aguardavam-se dez minutos para polimerização do cimento (Figura 4.6). Para confirmar se a cimentação fora feita corretamente, a altura do pino era novamente medida com um compasso.

A porção coronária do pino era submetida a novo tratamento adesivo (silano, primer e adesivo do sistema Scotchbond Multi-Uso Plus), seguindo-se estritamente as instruções do fabricante. Para confecção da porção coronária do núcleo foi utilizada a resina composta Enforce-Core, idealizada para construção de núcleos de preenchimento. A forma e dimensão da porção coronária dos núcleos foram obtidas de forma padronizada através das matrizes de polipropileno anteriormente confeccionadas para o grupo 1.

A resina para confecção da porção coronária do núcleo foi injetada com seringa Centrix no interior da matriz, que foi posicionada sobre o pino. Os excessos de Enforce-Core foram removidos com espátula de teflon para inserção de resina composta e a unidade de luz visível foi então aplicada por 40 segundos em cada face, após o que a matriz foi mantida imóvel durante mais seis minutos. Quando presentes, os excessos da porção coronária dos núcleos de preenchimento foram eliminados com pontas diamantadas 3216 e 4138 em baixa rotação no contra-ângulo (Figura 4.7). 


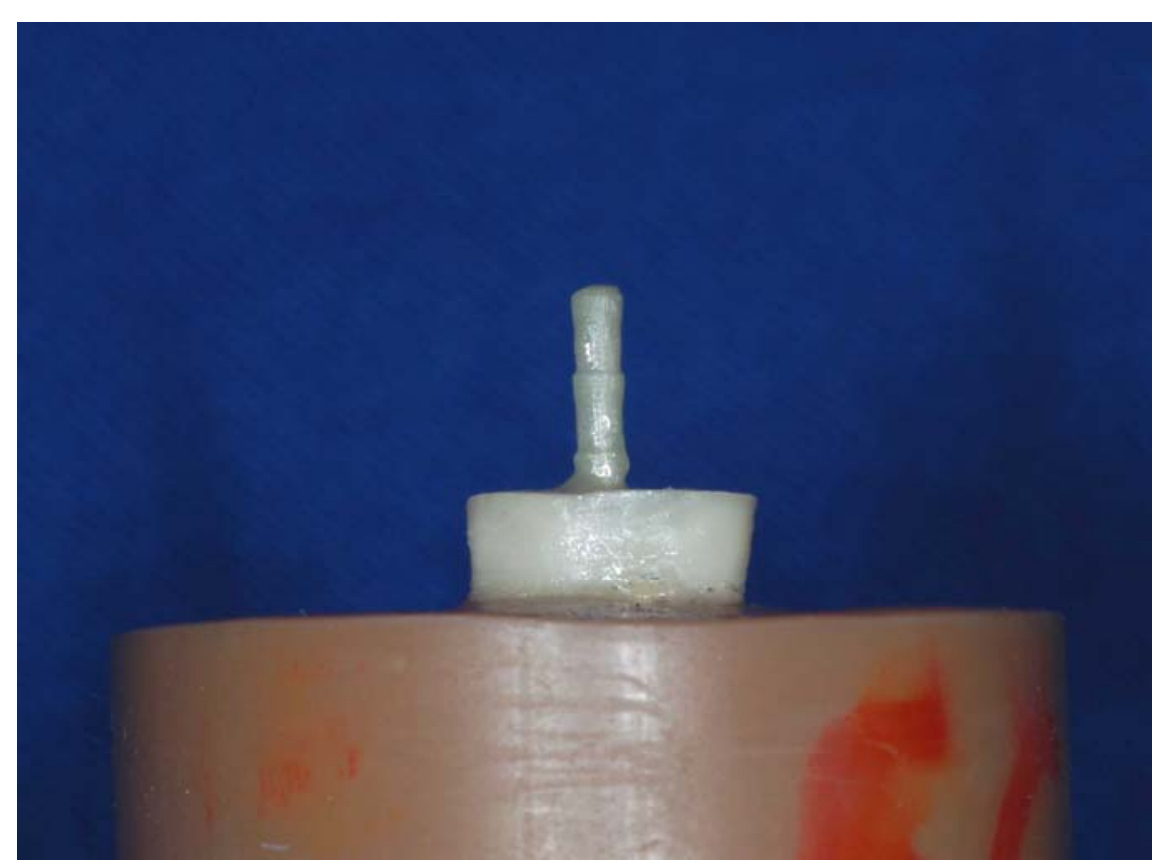

FIGURA 4.6 - Pino de fibras de vidro Fibrekor cimentado no canal radicular com cimento resinoso

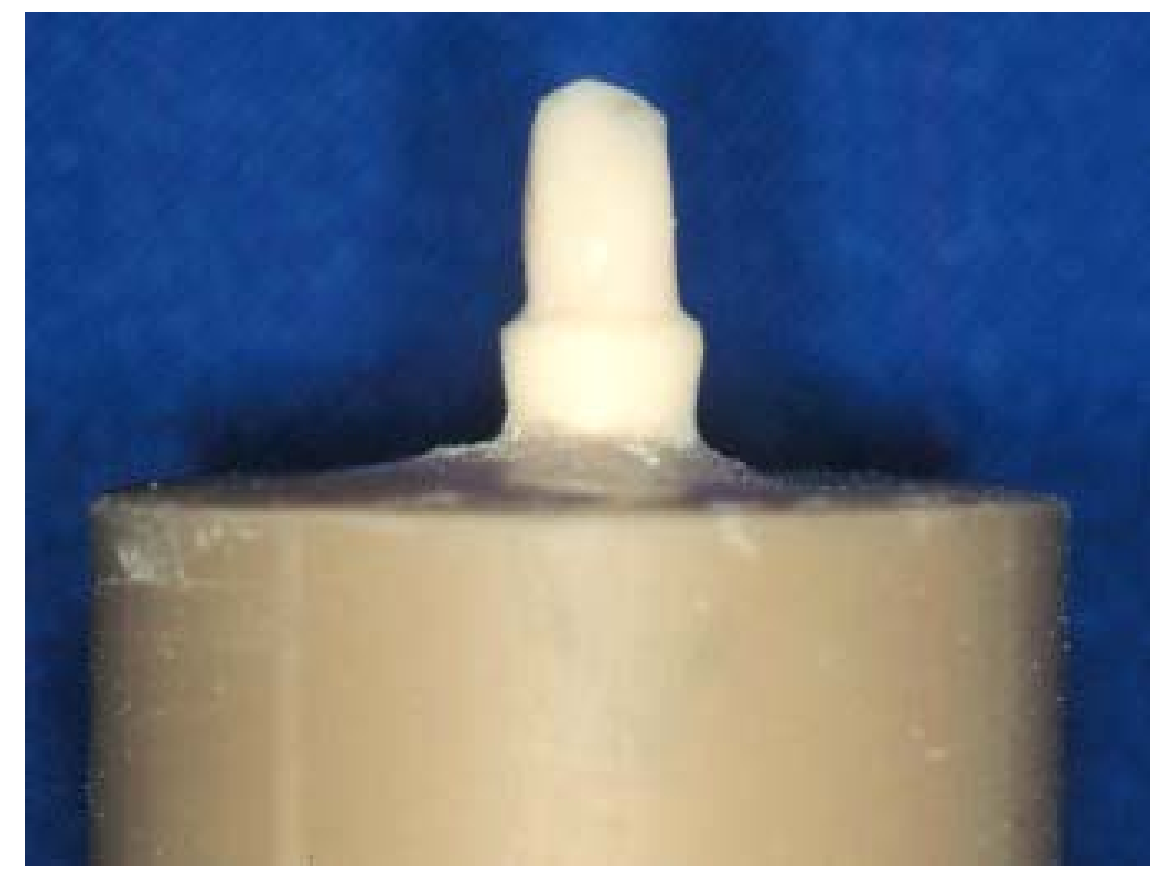

FIGURA 4.7 - Vista frontal da porção coronária de um espécime do grupo 2 confeccionada com resina composta Enforce-Core

c. Preparo dos corpos de prova do grupo 3

Foram confeccionados 10 núcleos de preenchimento utilizando o pino de fibras de vidro FibreKor $\mathrm{n}^{\circ} 2$, envolvido por fitas de fibras de vidro Interlig $(2 \mathrm{~mm}$ de 
largura e $0,20 \mathrm{~mm}$ de espessura). A utilização das fitas visou o preenchimento de espaços vazios entre o pino e as paredes do conduto radicular, uma vez que o pino utilizado possuía diâmetro inferior ao do conduto.

Foram cortados dois pedaços de fita de fibras de vidro com $40 \mathrm{~mm}$ de comprimento cada; esta fita já é fornecida pré-impregnada por resina composta fotopolimerizável. O material foi manipulado somente com instrumentos metálicos, para evitar sua contaminação pelo contato com os dedos desprotegidos ou mesmo com luvas de látex. A fita foi protegida da luz em uma caixa metálica até o momento do uso, para que não ocorresse polimerização prévia da resina. Também neste grupo o pino foi reduzido no comprimento, de forma que sua altura extra-radicular fosse de $5 \mathrm{~mm}$. Os condutos e os pinos passaram pelo mesmo tratamento adesivo descrito no grupo 2.

Para a cimentação do conjunto, foi utilizado novamente cimento resinoso RelyX CRA. O cimento foi levado ao conduto radicular com lentulo e aplicado sobre as fitas com pincel descartável pequeno. As fitas foram cruzadas sobre a embocadura do conduto em uma orientação perpendicular entre si e levadas ao seu interior com condensadores endodônticos $n^{\circ} 2$ e 3 . O próximo passo foi o ajuste das fitas sobre as paredes laterais do conduto, mantendo espaço para inserção do pino de fibras de vidro entre elas. Foi aplicado cimento sobre o pino com um pincel, inserindoo a seguir entre as fibras.

As quatro pontas de fibras de vidro que ficavam emergindo do conduto eram acomodadas em torno da porção extra-radicular do pino, para auxiliar no suporte para a resina da porção coronária do núcleo (Figura 4.8A). Para tal, era utilizado um porta-agulha para trançar as fibras ao redor do pino (Figura 4.8B). Acrescentava-se mais cimento para unir as fibras entre si e à porção coronária do pino. O conjunto foi fotopolimerizado por 40 segundos em cada face. Após a polimerização, o porta-agulha era removido e o excesso de fibras cortado com uma tesoura cirúrgica. Quando necessário, removeram-se excessos maiores com uma ponta diamantada 3216. Após seis minutos, confeccionou-se a porção coronária do núcleo, seguindo os passos apresentados para o grupo 2 . 


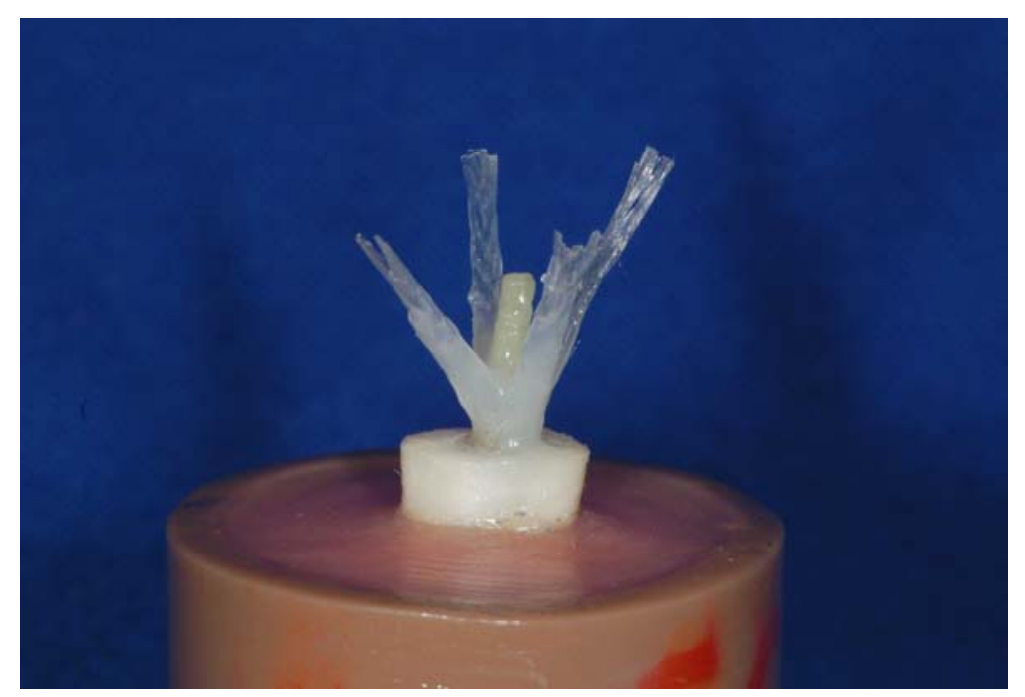

A

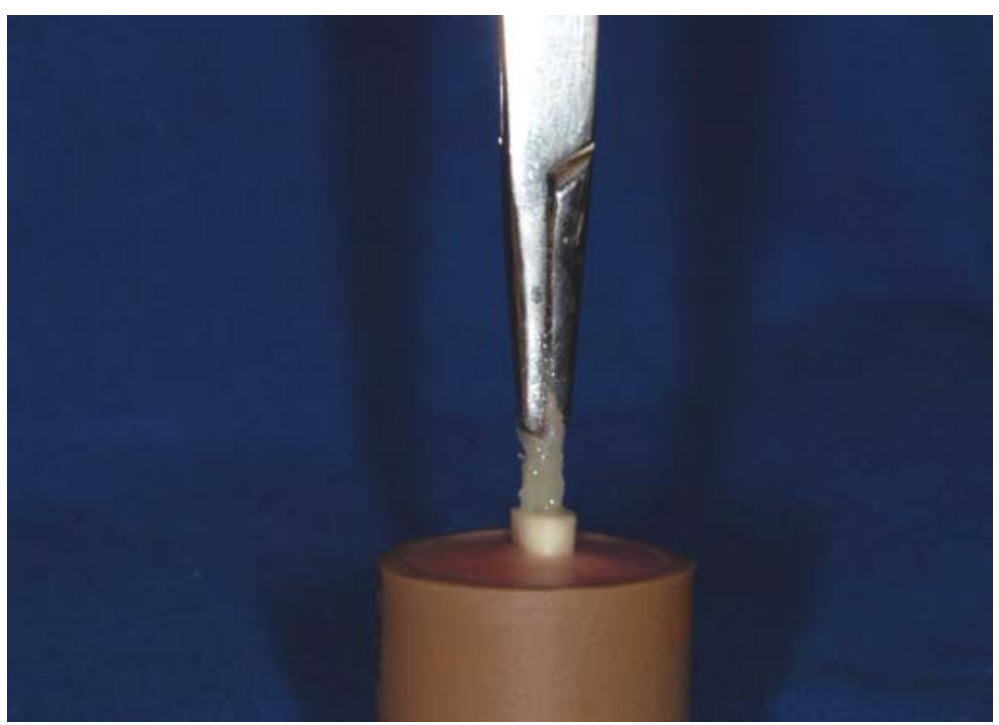

B

FIGURA 4.8 -Confecção de um núcleo de preenchimento do grupo 3 pela associação de um pino de fibras de vidro com fitas de fibras de vidro

A) Fitas de fibras de vidro emergindo do conduto, em torno do pino de fibras de vidro

B) Utilização do porta-agulha para conformação das fitas em torno do pino de fibras de vidro

\section{d. Preparo dos corpos de prova do grupo 4}

Foram confeccionados 10 núcleos de preenchimento com o pino de fibras de vidro FibreKor $n^{\circ} 2$, combinado com pinos de fibra de vidro acessórios (micro-pinos) Reforpin, os quais têm a finalidade de preencher espaços vazios quando o pino de fibra de vidro adapta-se imprecisamente a condutos cônicos ou alargados. O papel dos pinos acessórios é, assim, similar ao dos cones de guta-percha acessórios utilizados na obturação endodôntica. Desta forma, durante a cimentação 
do pino de fibra de vidro principal (FibreKor $n^{\circ} 2$ ), os espaços vazios em torno do mesmo foram preenchidos pela inserção de pinos de fibras de vidro acessórios.

Para o total preenchimento do conduto foi necessário utilizar, além do pino de fibra de vidro principal, um pino acessório de cada um dos três diâmetros fornecidos no kit ( $n^{\circ} 1, n^{\circ} 2$ e $\left.n^{\circ} 3\right)$. O pino de fibras de vidro principal foi ajustado no comprimento, como descrito para o grupo 2. Era feita então a delimitação da altura de corte dos pinos acessórios, que eram removidos do canal e cortados com uma ponta diamantada $\mathrm{n}^{\circ} 3216$ sob irrigação abundante.

Os condutos radiculares e os pinos de fibras de vidro foram submetidos ao tratamento adesivo de forma idêntica àquela exposta para o grupo 2 .

Para a cimentação de todos os pinos, foi utilizado mais uma vez o cimento resinoso RelyX CRA. O cimento foi levado ao conduto radicular com lentulo. Após aplicação de cimento sobre o pino principal, este foi inserido no conduto; o cimento foi aplicado então sobre os pinos acessórios, que foram inseridos do pino maior para o menor, sucessivamente, em torno do pino principal, até o preenchimento completo do conduto (Figura 4.9). O conjunto foi fotopolimerizado por 40 segundos em cada face. Após seis minutos, foi confeccionada a porção coronária do núcleo da mesma forma descrita no grupo 2 .

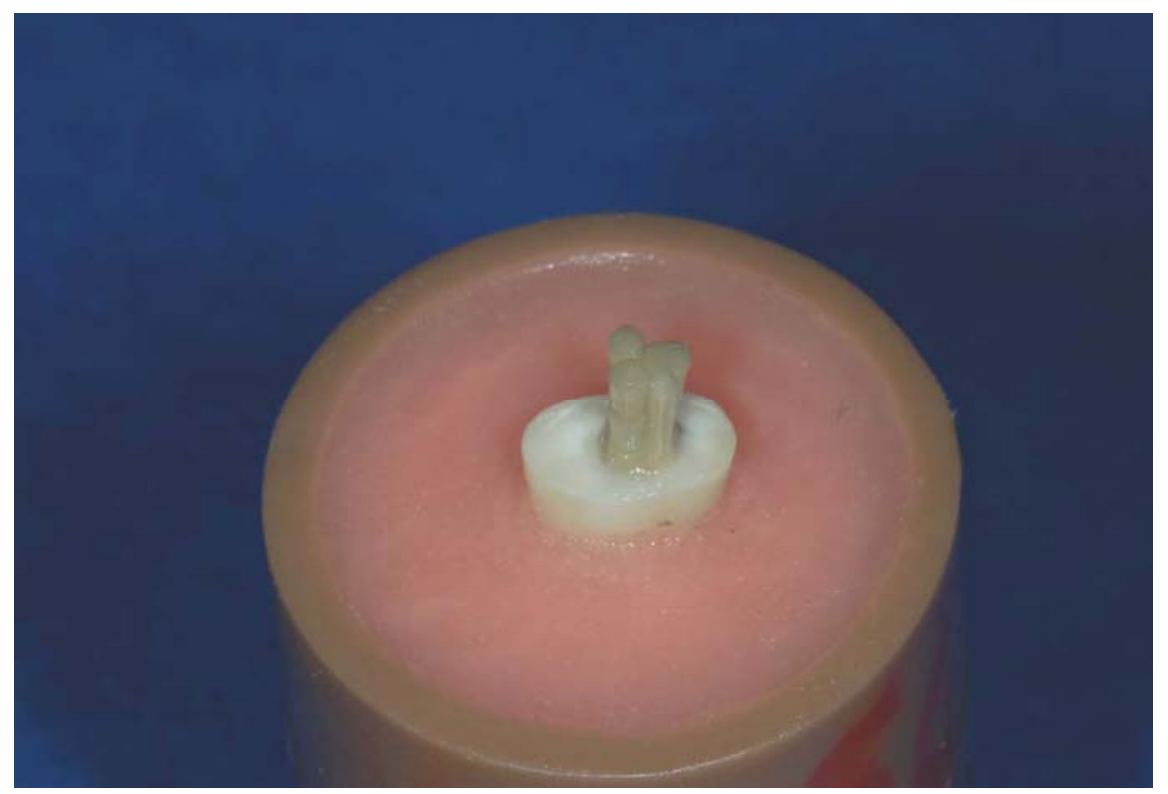

FIGURA 4.9 - Preenchimento do conduto com o pino de fibras de vidro principal e três pinos de fibras de vidro acessórios (grupo 4) 


\section{e. Preparo dos corpos de prova do grupo 5}

Foram confeccionados 10 pinos anatômicos, que consistiram no reembasamento de pinos de fibras de vidro FibreKor $n^{0} 2$ com uma resina composta de baixa viscosidade e posterior cimentação com cimento resinoso. Esta técnica permite a adaptação exata de um pino de fibras de vidro pré-fabricado à forma do conduto cônico ou amplo.

O conduto era lubrificado com um isolante à base de água (hidrossolúvel e a resina composta de baixa viscosidade (Filtek Flow) era inserida no conduto com a agulha fornecida pelo fabricante da resina, preenchendo-se lentamente o conduto, de forma a minimizar a formação de bolhas (Figura 4.10A). A seguir, o pino já tratado com o sistema adesivo da forma recomendada pelo fabricante era inserido no centro do conduto, utilizando-se um delineador para mantê-lo nesta posição. Se houvesse escoamento de excesso de resina, esta era eliminada com um pincel. A seguir, executava-se a pré-polimerização da resina por oclusal durante somente 30 segundos.

O pino reembasado era removido do conduto, para complementação da fotopolimerização durante mais 60 segundos em torno do pino (Figura 4.10B e Figura 4.10C). Verificava-se a seguir se a adaptação do pino no conduto ocorria sem dificuldades; quando necessário, foi utilizado o evidenciador de contatos Arti-Spot 2 para a obtenção de uma adaptação adequada (como no grupo 1). As mesmas técnicas utilizadas no grupo 2 foram aplicadas para tratamento adesivo do conduto e do pino anatômico, assim como para a cimentação e confecção da porção coronária do núcleo. A prensa estática foi utilizada durante a cimentação do pino anatômico, como descrito para o grupo 1. 

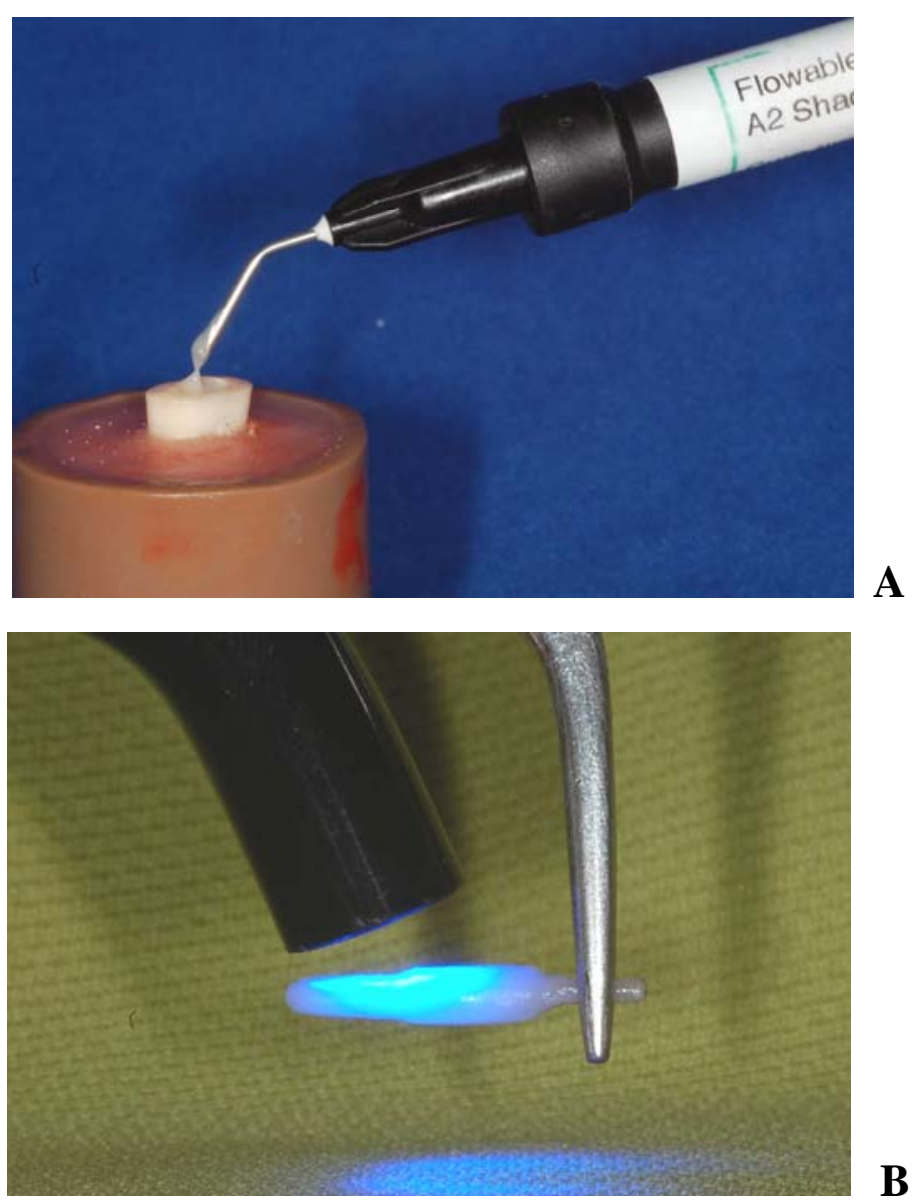

A

B

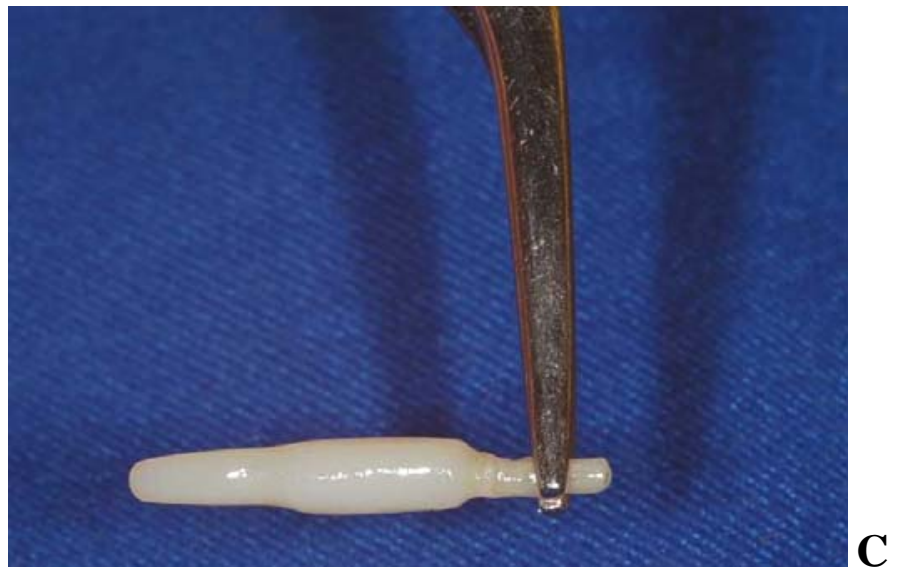

FIGURA 4.10 - Seqüência da confecção de um pino anatômico (grupo 5)

A) Resina composta de baixa viscosidade sendo injetada no conduto

B) Complementação da polimerização do pino anatômico após sua remoção do canal radicular

C) Pino anatômico já confeccionado 


\section{f. Confecção e cimentação de coroas totais metálicas}

Em um laboratório comercial, foram confeccionadas coroas totais metálicas simulando a anatomia de caninos, com dimensão e forma padronizada: $7 \mathrm{~mm}$ de altura e um degrau na porção palatina, localizado a $3 \mathrm{~mm}$ da borda incisal ${ }^{3}$, o qual tinha a função de evitar o deslize da ponta ativa da máquina de ensaios e servir como ponto padronizado da aplicação da força. A inclusão e a fundição destas coroas foram executadas com o mesmo revestimento e a mesma liga utilizados para a obtenção dos núcleos metálicos fundidos.

Quando as coroas foram recebidas do laboratório (numeradas de acordo com o número do espécime e do grupo), foram examinadas criteriosamente com lupa frontal de quatro aumentos e sonda exploradora para detecção de nódulos de fundição internos e/ou falhas de adaptação cervical. Quando presentes, os nódulos foram removidos com brocas esféricas $n^{\circ} 2$ de carboneto de tungstênio em baixa rotação. No caso de falta de adaptação da coroa, esta era pincelada internamente com uma fina camada de solução evidenciadora de contatos Arti-Spot 2 e, após secagem com jatos de ar, assentada sobre a porção coronária do núcleo. Nas áreas que impediam assentamento completo da coroa, a solução evidenciadora era removida. Estas áreas de atrito eram ajustadas com as brocas carbide até que uma película uniforme de evidenciador fosse observada. A confirmação da adaptação foi feita com sonda exploradora $n^{\circ} 5$ e lupa frontal de quatro aumentos.

Após serem jateadas internamente com óxido de alumínio (partículas de $50 \mu \mathrm{m}$ ), as coroas foram lavadas com água destilada e secas com jatos de ar. Para a cimentação das coroas, foi utilizado o cimento de ionômero de vidro modificado por resina RelyX Luting. A proporção pó / líquido deste cimento é 1,6:1 em peso e é obtida usando-se um número igual de colheres de pó e gotas de líquido. Desta forma, foi proporcionada 1 colher dosadora de pó, que foi manipulada com 1 gota de líquido por cerca de 30 segundos, até obtenção de uma mistura uniforme. Uma pequena porção de cimento foi aplicada internamente nas coroas (na borda cervical) com um pincel descartável. Após o assentamento da coroa sobre o núcleo, foi aplicada uma carga de $5 \mathrm{~kg}$ sobre a mesma na prensa estática. Depois de 10 minutos, os excessos foram removidos e o espécime foi removido da prensa estática. 


\subsubsection{Teste de resistência à fratura sob compressão}

Depois de obtidos os corpos de prova, os mesmos foram imersos em água destilada a $37^{\circ} \mathrm{C}$ durante 24 horas. Após este período, os corpos de prova foram submetidos ao ensaio de resistência à fratura em uma máquina de ensaios universal Kratos, através de carregamento de compressão. As condições do teste foram ajustadas para simular a situação in vivo. Os corpos de prova foram acoplados à máquina de ensaios e os dentes foram submetidos à carga estática progressiva, à velocidade de $0,5 \mathrm{~mm} / \mathrm{min}$, utilizando uma célula com capacidade de carga de até $500 \mathrm{kgf}$.

O ponto de aplicação da força foi sempre no degrau da face palatina em todos os espécimes, assegurando assim que a distribuição das cargas fosse sempre semelhante e na mesma direção. A extremidade da ponta ativa utilizada para a aplicação da força compressiva era plana e adaptava-se ao degrau confeccionado na coroa total metálica cimentada sobre os núcleos. Antes do teste, a ponta era localizada o mais próxima possível do corpo de prova, porém sem tocá-lo, o que era aferido usando duas matrizes de celulóide como espaçador.

Um dispositivo de aço especial acoplado à porção inferior da máquina de ensaios permitiu a colocação do corpo de prova durante a execução dos testes de forma que o espécime ficasse posicionado em uma inclinação de $45^{\circ}$ em relação ao plano horizontal ( $135^{\circ}$ em relação ao longo eixo do dente), fazendo com que a carga de compressão fosse aplicada simulando uma condição clínica de oclusão do tipo classe I. A ponta ativa que imprimiu a força de compressão foi adaptada na porção superior da máquina de ensaios (Figura 4.11 e Figura 4.12).

A máquina de ensaios foi programada de forma que a carga fosse automaticamente descontinuada (paralisação da máquina) quando o sistema de alguma forma falhasse (deslocamento ou fratura do núcleo ou da porção coronária ou ainda fratura da raiz). 


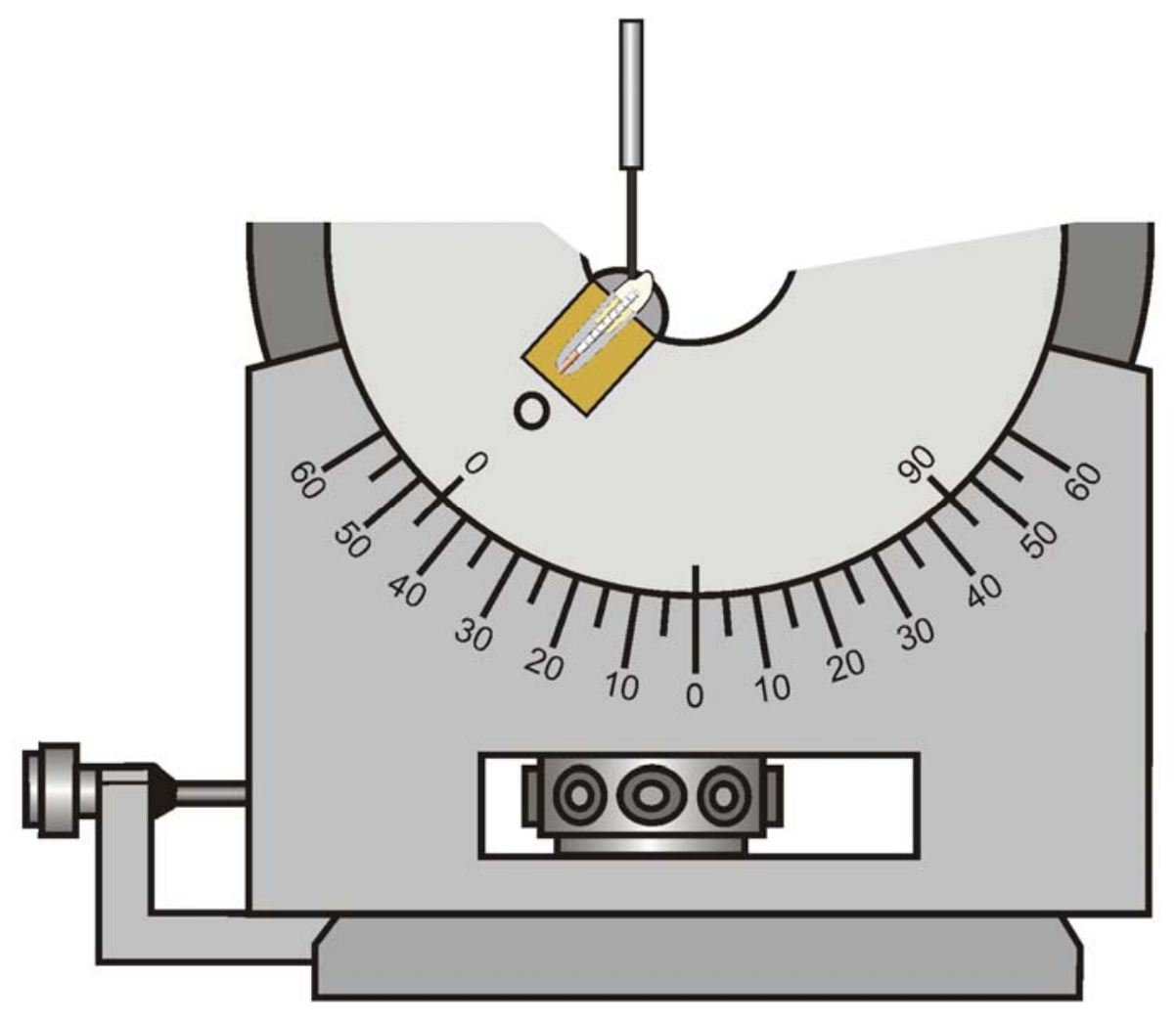

FIGURA 4.11 - Representação esquemática do carregamento de compressão formando um ângulo de $45^{\circ}$ em relação ao plano horizontal $\left(135^{\circ}\right.$ em relação ao longo eixo do dente)

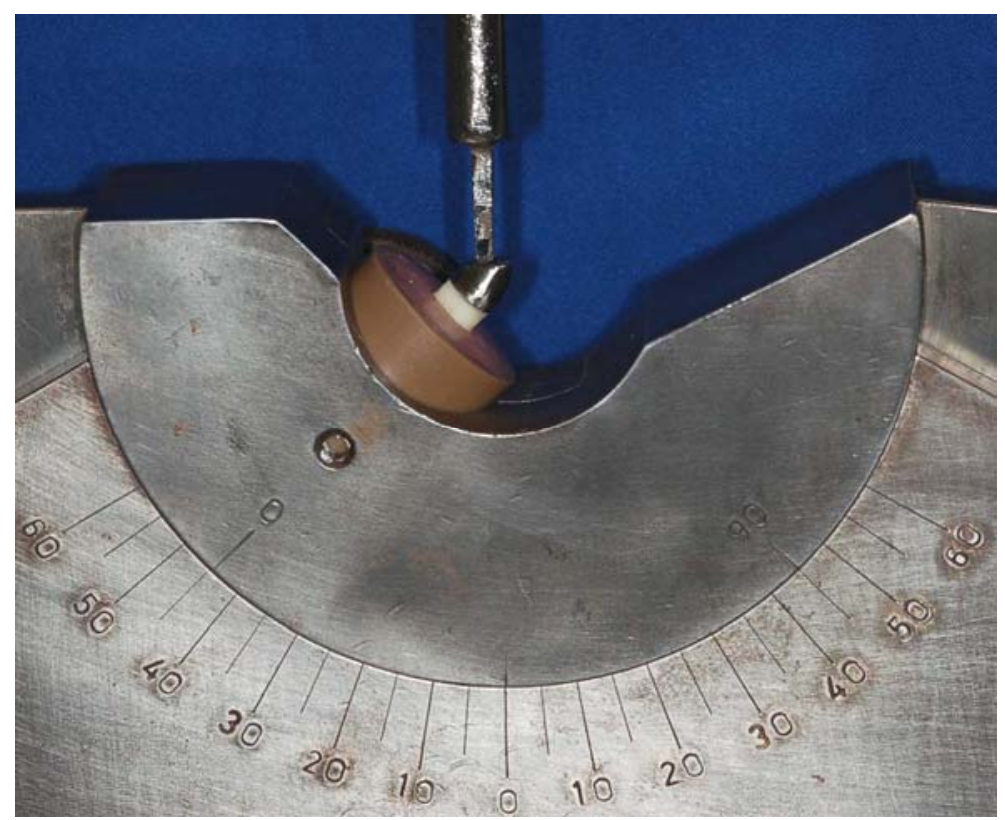

FIGURA 4.12 - Visão aproximada do carregamento de compressão formando um ângulo de $45^{\circ} \mathrm{em}$ relação ao plano horizontal $\left(135^{\circ}\right.$ em relação ao longo eixo do dente) 


\subsubsection{Registro da carga necessária para falha}

Para todos os corpos de prova, tanto a carga necessária para causar a falha quanto o modo como esta ocorreu foram registrados. O limiar de falha e o gráfico de aplicação das forças foram emitidos no monitor do computador acoplado à maquina universal de ensaios e posteriormente impressos.

\subsection{Análise dos resultados}

Os resultados obtidos durante os testes de resistência à fratura sob compressão foram organizados para tratamento estatístico. Foi empregada análise descritiva, com o uso de tabelas, gráficos e parâmetros de média e desvio-padrão.

Para comparação das médias, foi utilizada a Análise de Variância (ANOVA) a um critério. Se a Análise de Variância demonstrasse diferença estatisticamente significativa entre os grupos estudados, seria utilizado o teste de Tukey para comparações múltiplas.

Em todas as induções estatísticas, foi adotado nível de significância de $5 \%$. 
5 RESULTADOS 


\section{RESULTADOS}

Os valores (em kgf) obtidos para cada corpo de prova após os ensaios de resistência à fratura sob compressão na máquina de ensaios universal, suas respectivas médias e desvios padrão são apresentados na Tabela 5.1.

TABELA 5.1 - Valores individuais de resistência à fratura (em kgf) para cada corpo de prova, médias e respectivos desvios padrão para cada grupo experimental

\begin{tabular}{cccccc}
\hline $\begin{array}{c}\text { CORPO DE } \\
\text { PROVA }\end{array}$ & GRUPO 1 & GRUPO 2 & GRUPO 3 & GRUPO 4 & GRUPO 5 \\
\hline 1 & 114,00 & 84,50 & 86,87 & 93,75 & 89,25 \\
\hline 2 & 84,92 & 75,60 & 79,75 & 89,75 & 63,00 \\
\hline 3 & 108,67 & 124,10 & 85,37 & 66,25 & 95,50 \\
\hline 4 & 87,00 & 44,65 & 76,00 & 111,50 & 103,00 \\
\hline 5 & 91,40 & 106,00 & 108,20 & 86,00 & 70,00 \\
\hline 7 & 92,95 & 69,37 & 69,80 & 81,00 & 79,02 \\
\hline 8 & 152,40 & 56,25 & 41,75 & 98,75 & 69,57 \\
\hline 9 & 102,10 & 51,32 & 53,75 & 93,00 & 104,95 \\
\hline 10 & 145,45 & 94,80 & 82,00 & 101,55 & 119,92 \\
\hline MÉDIA & 129,70 & 53,87 & 107,30 & 117,30 & 99,27 \\
\hline DESVIO PADRÃO & $\mathbf{2 4 , 2 8}$ & $\mathbf{2 6 , 1 5}$ & $\mathbf{2 0 , 7 7}$ & $\mathbf{1 4 , 7 2}$ & $\mathbf{1 8 , 4 6}$ \\
\hline & & & & & \\
\hline & $\mathbf{2 1 0 , 8 5}$ & $\mathbf{7 6 , 0 4}$ & $\mathbf{7 9 , 0 7}$ & $\mathbf{9 3 , 8 8}$ & $\mathbf{8 9 , 3 4}$ \\
\hline & & & & & \\
\hline
\end{tabular}

Grupo 1 - Núcleo metálico fundido totalmente adaptado ao conduto radicular

Grupo 2 - Pino de fibras de vidro de diâmetro menor que o do conduto, envolvido apenas por cimento resinoso 
Grupo 3 - Pino de fibras de vidro de diâmetro menor que o do conduto, envolvido por fitas de fibras de vidro

Grupo 4 - Pino de fibras de vidro de diâmetro menor que o do conduto, combinado com pinos de fibras de vidro acessórios

Grupo 5 - Pino anatômico (pino de fibras de vidro de diâmetro menor que o do conduto, reembasado com resina composta de baixa viscosidade)

Pode-se observar as médias de resistência à fratura e desvios padrão para cada grupo experimental na Tabela 5.2 e na Figura 5.1.

TABELA 5.2 - Médias de resistência à fratura (em kgf) e respectivos desvios padrão em cada grupo experimental

\begin{tabular}{ccc}
\hline GRUPOS & MÉDIA & DESVIO PADRÃO \\
\hline 1 & 110,85 & 24,28 \\
2 & 76,04 & 26,15 \\
3 & 79,07 & 20,77 \\
4 & 93,88 & 14,72 \\
5 & 89,34 & 18,46 \\
\hline
\end{tabular}




\section{Médias de Resistência à Fratura dos Grupos Experimentais}

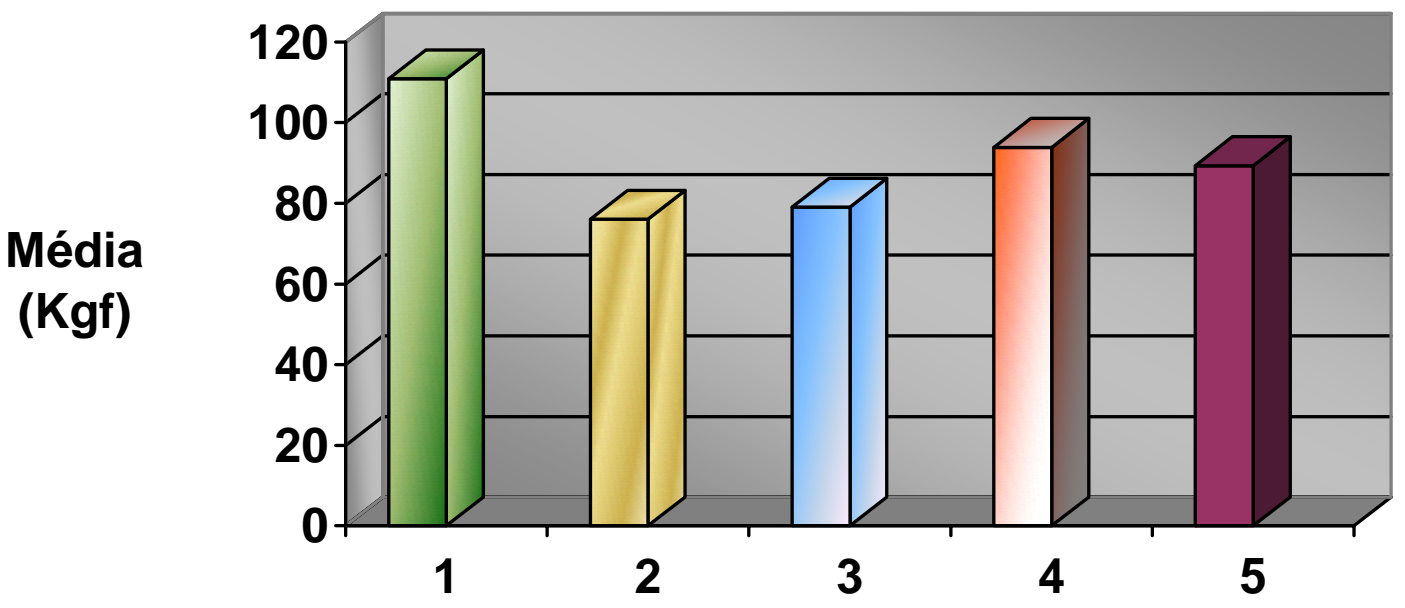

\section{Grupos}

FIGURA 5.1 - Gráfico representativo das médias de resistência à fratura dos grupos experimentais

Os valores de resistência à fratura obtidos após os testes foram submetidos à Análise de Variância a um critério (ANOVA), a qual demonstrou existir diferença estatisticamente significativa entre os grupos (Tabela 5.3). A seguir, foi aplicado o teste de Tukey para comparações múltiplas, visando localizar as diferenças entre os grupos experimentais (Tabela 5.4A e Tabela 5.4B).

O teste de Tukey revelou a existência de diferença estatisticamente significativa entre o grupo 1 e o grupo 2, assim como entre o grupo 1 e o grupo 3, não encontrando diferenças significativas entre os demais grupos quando comparados entre si.

TABELA 5.3 - Resultados da Análise de Variância a um critério (ANOVA) para o ensaio de resistência à fratura das raízes

\begin{tabular}{ccccccc}
\hline $\begin{array}{c}\text { Graus de } \\
\text { Liberdade }\end{array}$ & $\begin{array}{c}\text { Quadrado } \\
\text { Médio }\end{array}$ & $\begin{array}{c}\text { Graus de } \\
\text { Liberdade }\end{array}$ & $\begin{array}{c}\text { Quadrado } \\
\text { Médio }\end{array}$ & F & $\begin{array}{c}\text { Probabilidade } \\
\text { (p) }\end{array}$ \\
Efeito & Efeito & Erro & Erro & & $0,005489^{*}$ \\
\hline 4 & 1911,190 & 45 & 452,6080 & 4,222616 & 0,000 \\
\hline
\end{tabular}

* diferença estatisticamente significativa $(p<0,05)$ 
TABELA 5.4A - Teste de TUKEY para comparações múltiplas

\begin{tabular}{cc}
\hline COMPARAÇÕES & PROBABILIDADE $(\mathbf{p})$ \\
\hline Grupo 1 x Grupo 2 & $0,005814^{*}$ \\
Grupo 1 x Grupo 3 & $0,014001^{*}$ \\
Grupo 1 x Grupo 4 & 0,395363 n.s. \\
Grupo 1 x Grupo 5 & 0,176857 n.s. \\
Grupo 2 x Grupo 3 & 0,997722 n.s. \\
Grupo 2 x Grupo 4 & 0,345416 n.s. \\
Grupo 2 x Grupo 5 & 0,632094 n.s. \\
Grupo 3 x Grupo 4 & 0,532564 n.s. \\
Grupo 3 x Grupo 5 & 0,816176 n.s. \\
Grupo 5 x Grupo 4 & 0,989148 n.s. \\
\hline
\end{tabular}

n.s. diferença estatisticamente não-significativa

* diferença estatisticamente significativa

TABELA 5.4B - Teste de TUKEY para comparações múltiplas

\begin{tabular}{cc|c}
\hline COMPARAÇÕES & MÉDIA \\
\hline Grupo 2 & 76,04 & \\
Grupo 3 & 79,07 & \\
Grupo 5 & 89,34 & \\
Grupo 4 & 93,88 & \\
Grupo 1 & 110,85 & \\
\hline
\end{tabular}

(Os grupos unidos por reta vertical não possuem diferença estatisticamente significativa entre si)

$\mathrm{Na}$ Tabela 5.5, é apresentado o padrão de fratura que ocorreu nos grupos experimentais (os terços radiculares foram considerados a cada $5 \mathrm{~mm}$ ). 
TABELA 5.5 - Padrão de fratura observado para os grupos experimentais

\begin{tabular}{c|c|c|c|c|c}
\hline $\begin{array}{c}\text { PADRÃO DE } \\
\text { FRATURA }\end{array}$ & $\begin{array}{c}\text { GRUPO } \\
\mathbf{1}\end{array}$ & $\begin{array}{c}\text { GRUPO } \\
\mathbf{2}\end{array}$ & $\begin{array}{c}\text { GRUPO } \\
\mathbf{3}\end{array}$ & $\begin{array}{c}\text { GRUPO } \\
\mathbf{4}\end{array}$ & $\begin{array}{c}\text { GRUPO } \\
\mathbf{5}\end{array}$ \\
\hline $\begin{array}{c}\text { Flexão ou fratura do pino e/ou } \\
\text { porção coronária do núcleo, com } \\
\text { deslocamento parcial da coroa }\end{array}$ & - & $4(40 \%)$ & $3(30 \%)$ & $3(30 \%)$ & $5(50 \%)$ \\
\hline $\begin{array}{c}\text { Fratura oblíqua, estendendo-se } \\
\text { até o terço cervical da raiz }\end{array}$ & $3(30 \%)$ & $4(40 \%)$ & $6(60 \%)$ & $4(40 \%)$ & $3(30 \%)$ \\
\hline $\begin{array}{c}\text { Fratura oblíqua, estendendo-se } \\
\text { até o terço médio da raiz }\end{array}$ & $6(60 \%)$ & $2(20 \%)$ & $1(10 \%)$ & $3(30 \%)$ & $2(20 \%)$ \\
\hline $\begin{array}{c}\text { Fratura longitudinal da raiz } \\
\text { (10\%) }\end{array}$ & $1-$ & - & - & - \\
\hline
\end{tabular}

Na Figura 5.2, pode-se observar uma representação gráfica do padrão de falha para os grupos experimentais.

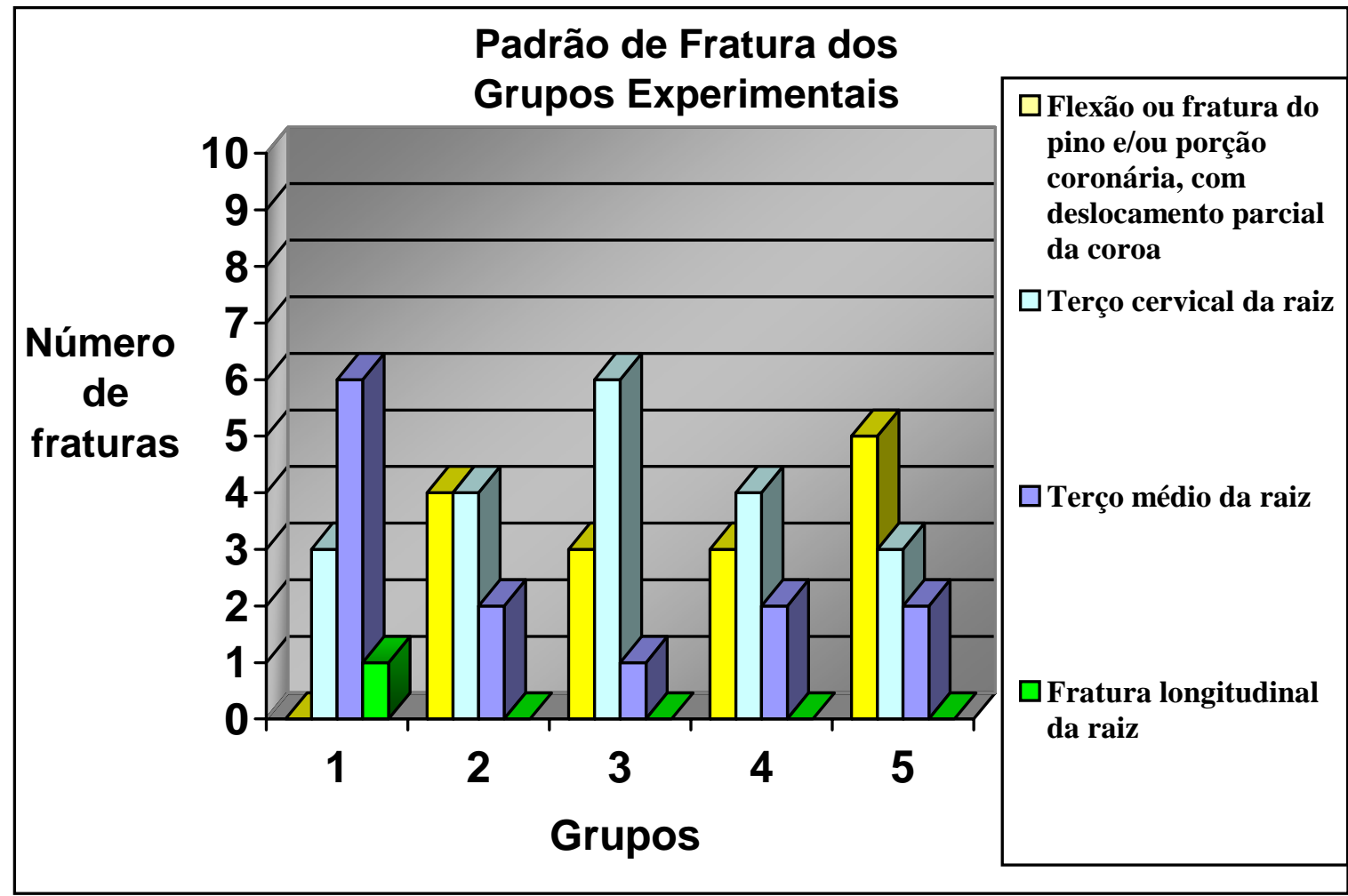

FIGURA 5.2 - Representação gráfica do padrão de fratura observado nos grupos experimentais 
Finalmente, a Tabela 5.6 demonstra a porcentagem de espécimes, em cada um dos grupos, nos quais ocorreu um padrão de fratura favorável e aqueles onde a fratura foi do tipo desfavorável. Considerou-se a fratura desfavorável (irreparável) quando os dentes exibiram fraturas verticais ou oblíquas estendendo-se abaixo da crista óssea (no laboratório isso correspondia a fraturas abaixo do nível ósseo simulado, que era a borda do bloco de resina acrílica ${ }^{22}$. Como fraturas favoráveis (ou reparáveis) devem-se entender aquelas que ocorrem ao nível ou acima da crista marginal (ou do nível ósseo simulado), permitindo a conservação do remanescente dentário ${ }^{92}$. Deve-se lembrar que nos testes in vitro costuma-se manter expostos 2 a $3 \mathrm{~mm}$ dos dentes acima do bloco de resina. Também são favoráveis as situações em que ocorre a fratura apenas da porção coronária do núcleo.

TABELA 5.6 - Porcentagem de corpos de prova com padrão de fratura favorável ou desfavorável em cada grupo

\begin{tabular}{c|c|c|c|c|c}
\hline $\begin{array}{c}\text { TIPO DE } \\
\text { FRATURA }\end{array}$ & Grupo 1 & Grupo 2 & Grupo 3 & Grupo 4 & Grupo 5 \\
\hline Favorável & $30 \%$ & $80 \%$ & $90 \%$ & $70 \%$ & $80 \%$ \\
\hline Desfavorável & $70 \%$ & $20 \%$ & $10 \%$ & $30 \%$ & $20 \%$ \\
\hline
\end{tabular}

Conforme representado na Tabela 5.5 e na Figura 5.2, no grupo 1 (núcleos metálicos fundidos) não ocorreram fraturas ou flexões do pino e/ou porção coronária do núcleo. O tipo de fratura mais usual neste grupo foi a fratura da raiz ao nível do terço médio radicular (60\%), seguido pela fratura ao nível do terço cervical da raiz $(30 \%)$. Este também foi o único grupo no qual ocorreu uma fratura longitudinal da raiz.

O grupo 2 e o grupo 4 apresentaram padrão e porcentagem de falhas similares.

No grupo 2, 40\% das falhas ocorreram por flexão ou fratura do pino e/ou porção coronária do núcleo (com conseqüente deslocamento da coroa), sendo que houve uma porcentagem igual de fraturas no terço cervical da raiz. As demais falhas, que foram a minoria, foram fraturas no terço médio da raiz.

No grupo 4, ocorreu uma porcentagem igual de falhas por flexão ou fratura do pino e/ou da porção coronária do núcleo, assim como de fraturas do terço 
médio da raiz ( $30 \%$ de cada tipo de falha). A maioria das falhas ocorreu por fratura no terço cervical da raiz $(40 \%)$.

A principal observação que deve ser feita no grupo 3 foi a ocorrência de uma maior porcentagem de fraturas no terço cervical da raiz $(60 \%)$. A segunda falha mais comum neste grupo foi por flexão ou fratura do pino e/ou porção coronária do núcleo $(30 \%)$. Ocorreu apenas uma falha por fratura no terço médio radicular.

A maior peculiaridade do grupo 5 foi que metade das falhas foram resultado de flexão ou fratura do pino e/ou da porção coronária do núcleo. As demais falhas foram por fratura ao nível do terço cervical da raiz $(30 \%)$ ou ao nível do terço médio da raiz (em somente $20 \%$ dos espécimes).

Pode-se observar na Tabela 5.6 que o grupo 3 foi aquele que obteve a maior quantidade de espécimes com padrão de fratura favorável $(90 \%)$, seguido pelos grupos 2 e 5 (ambos com $80 \%$ ) e pelo grupo 4 (com $70 \%$ ).

O grupo 1 (núcleos metálicos fundidos) apresentou um número de espécimes com padrão favorável de fraturas significativamente inferior (30\%) aos grupos 2 a 5 (restaurados com pinos de fibras de vidro). Deve-se salientar ainda que as falhas no terço médio da raiz foram a minoria nos grupos 2 a 5 , nunca ultrapassando a porcentagem de $30 \%$. 
6 DISCUSSÃO 


\section{DISCUSSÃO}

$\mathrm{Na}$ década de 1980, observou-se que em raízes com alargamento excessivo do conduto (devido a cáries extensas, uso prévio de núcleos com largo diâmetro, iatrogenias durante a abertura da câmara coronária, sobreinstrumentação endodôntica, rizogênese incompleta, reabsorção interna ou anomalias de desenvolvimento), a restauração com núcleos convencionais pode tornar-se difícil ou mesmo inviável ${ }^{57,68,74,75}$. Núcleos metálicos fundidos agiriam como cunha, precipitando a fratura destas raízes fragilizadas, enquanto pinos pré-fabricados adaptar-se-iam imprecisamente aos condutos alargados e ficariam envolvidos por quantidades excessivas de cimento ${ }^{57,68,74,75}$. Uma forma adequada de reforço para raízes com paredes muito finas é fundamental, pois estão mais propensas a fraturar na cimentação dos pinos ou durante atividades funcionais e parafuncionais ${ }^{68,74,75,114,131}$.

O estudo de TJAN; WHANG ${ }^{131}$, em 1985, demonstrou que quanto menor a espessura da parede radicular, maior é o risco de fratura da raiz. Estes autores avaliaram a influência da espessura da parede vestibular do conduto sobre a resistência à fratura dentária. Cimentaram núcleos metálicos fundidos em 40 incisivos superiores com espessura de dentina vestibular dos condutos de $1 \mathrm{~mm}$ (grupo 1), $2 \mathrm{~mm}$ (grupo 2), 3mm (grupo 3) ou $1 \mathrm{~mm}$ com bisel de $60^{\circ}$ para formação de colar metálico (grupo 4). Submeteram os espécimes à compressão na máquina de ensaios e não registraram diferenças significativas na resistência à fratura entre os quatro grupos, mas houve diferenças no padrão de falhas: no grupo 1 todas as raízes fraturaram, no grupo 2 fraturaram oito raízes, no grupo 3 duas raízes e no grupo 4 fraturaram sete raízes. A utilização do colar metálico não aumentou a resistência à fratura.

$\mathrm{Na}$ tentativa de reforçar as raízes debilitadas, evitando sua perda precoce, diferentes materiais foram sugeridos e testados, como o ionômero de vidro $^{120,133}$ e a resina composta ${ }^{74,75,80,114,120,133}$, com maior sucesso para a segunda opção. Recentemente, tem-se proposto a confecção de pinos dentários, a partir de dentes naturais obtidos em bancos de dentes ${ }^{13,62}$.

É de extrema importância a obtenção de um sistema de núcleos com propriedades físico-mecânicas adequadas, preferencialmente similares às da estrutura dentária perdida, que atue como dentina artificial, reforçando raízes estruturalmente enfraquecidas. Como é de conhecimento geral, ainda hoje a maioria dos profissionais 
opta pela exodontia destes elementos por temer um prognóstico adverso a longo prazo $^{75}$. Entretanto, muitas vezes a destruição radicular interna está restrita à porção cervical do conduto, enquanto a porção média e apical possuem adequado suporte dentinário ${ }^{13,75}$.

Diversos autores sugeriram que a utilização de pinos com propriedades mecânicas semelhantes às da dentina e que sejam capazes de aderir ao remanescente dentário, agente cimentante e material de preenchimento coronário poderia proporcionar um reforço real da estrutura dentária remanescente ${ }^{26,27,40,41,57,59,60,63,67,109,130}$. Materiais com estas características seriam especialmente recomendados quando não existe nenhum remanescente coronário, de forma a permitir obtenção de uma férula extracoronária convencional - teoricamente, estes materiais adesivos permitiriam a obtenção de um "abraçamento" ou "amarramento" interno da dentina radicular ${ }^{127}$. Segundo STEWARDSON ${ }^{127}$, em 2001 e ESKITAŞCIOĞLU; BELLI; KALKAN ${ }^{29}$, em 2002, a utilização de pinos com materiais menos rígidos que a dentina gera menor transferência de estresse para as estruturas radiculares e, se o material do pino é levemente menos resistente que a dentina, é provável que o pino frature antes que a raiz.

A partir de 1990, houve uma significativa alteração nos materiais utilizados para a fabricação de pinos intra-radiculares, que mudaram de materiais muito rígidos (metais como aço inoxidável, ouro e titânio, entre outros, bem como o dióxido de zircônio) para materiais com características mais flexíveis (pinos de resina reforçada por fibras). O primeiro pino de fibras lançado no mercado foi o pino de fibras de carbono, introduzido por DURET, em $1990^{78}$; posteriormente, seguiram-se os pinos de fibras de vidro ou de quartzo $4,14,32,41,67,86,127$ e os pinos de fibras de polietileno $^{14,29,32,41,56,59,63,65,67,68,82,117,119,127,130}$.

Atualmente, pinos de resina reforçada por fibras são rotineiramente utilizados na prática clínica. Contudo, esta prática é baseada muito mais em conhecimentos teóricos de propriedades dos materiais e experimentos laboratoriais do que em resultados de dados clínicos, uma vez que se pode considerar ainda escasso o número de estudos clínicos prospectivos disponíveis acerca deste assunto. A revisão de literatura executada nesta tese apresentou o conhecimento atual sobre a resistência à fratura e os modos de falha de pinos pré-fabricados de fibras e de pinos de fibras confeccionados diretamente no canal radicular, bem como estudos 
comparativos destes pinos com outros sistemas de núcleos (como núcleos metálicos fundidos, pinos pré-fabricados metálicos e pinos cerâmicos).

Apesar da falta de um número significativo de estudos de acompanhamento longitudinal a longo prazo, os pinos pré-fabricados de fibras atualmente são aceitos como uma alternativa viável a núcleos metálicos fundidos ou pinos metálicos pré-fabricados ${ }^{47,48}$. Em grande parte, isto ocorreu porque a maioria dos estudos clínicos e laboratoriais ${ }^{18,22,35,39,40,69,78,81,87,91,116,119}$ realizados com pinos de fibras demonstraram uma quase total ausência de fraturas radiculares ou de fraturas do próprio pino, sugerindo que o mesmo é adequado para suportar a reconstrução coronária em dentes tratados endodonticamente; quando as raízes fraturaram, geralmente seu reparo era possível. Este padrão favorável de falhas, que é comum a todos os pinos de fibras (vidro, quartzo, carbono ou polietileno) ocorreu principalmente devido ao seu módulo de elasticidade similar ao da dentina e à sua capacidade de adesão à estrutura dentária e aos materiais de reconstrução dentária ${ }^{4,22,35,76,84,87,91,107}$. Além disso, os pinos de fibras apresentam adequados valores de resistência à fratura $^{4,22,76,84,87}$. Os pinos de fibras de vidro ou de quartzo, especificamente, possuem propriedades mecânicas e comportamento clínico muito similar aos pinos de fibras de carbono $^{12}$.

A seleção de caninos superiores representa uma opção adequada para simular situações clínicas para dentes endodonticamente tratados, especialmente quando raízes debilitadas (com condutos alargados) irão ser simuladas; neste caso, são necessárias raízes largas para permitir o preparo do conduto com brocas de maior diâmetro. Muitos estudos anteriores $3,4,13,16,21,51,52,69,80,104,112,116,120,133$ relataram o uso destes dentes como uma forma aceitável para avaliar sistemas de pinos intraradiculares de diferentes materiais e formas.

O preparo do conduto para a simulação de raízes debilitadas varia segundo os autores de cada estudo, pois não há consenso ou protocolo padronizado para o que se propôs realizar. Assim, a forma do preparo foi baseada em pesquisas anteriores que trabalharam com situações de raízes enfraquecidas ${ }^{13,62,80,120}$. Foi selecionado um preparo denominado medianamente alargado ${ }^{62}$ e escalonado em dois degraus, ou seja, um preparo com $10 \mathrm{~mm}$ de profundidade em que a metade apical do conduto foi alargada até $1,8 \mathrm{~mm}$ e a metade coronária do conduto até $2,5 \mathrm{~mm}$ de diâmetro. O maior alargamento cervical foi executado pelo fato de que em raízes 
enfraquecidas geralmente é a região cervical que se apresenta com paredes mais finas, devido a várias razões, como processo carioso, sobre-instrumentação endodôntica, remoção de núcleos, etc. Todos os dentes utilizados neste estudo tiveram seus condutos preparados desta forma, para eliminar variáveis decorrentes de diferentes preparos do conduto. Com a utilização de brocas de diâmetro conhecido e com a mensuração cuidadosa da penetração destas brocas foi possível padronizar o preparo em todos os espécimes.

O preparo do conduto com $10 \mathrm{~mm}$ de profundidade foi adotado por equivaler a $2 / 3$ do remanescente dentário e ainda permitir a manutenção de $5 \mathrm{~mm}$ da obturação radicular ${ }^{58,115}$.

Diversos estudos anteriores ${ }^{6,11,73,83,106,121}$ indicaram que, idealmente, os pinos intra-radiculares deveriam ser utilizados em dentes despolpados ainda possuidores de algum remanescente coronário, para que seja possível a obtenção de efeito férula. A altura mínima de remanescente coronário sadio proposta em diferentes estudos é variável: $1 \mathrm{~mm}^{83,106,121}, 1,5 \mathrm{~mm}^{73}$ ou $2 \mathrm{~mm}^{6,11}$. RAYGOT; CHAl; JAMESON ${ }^{106}$, em 2001, afirmaram que a resistência de dentes endodonticamente tratados com mínima quantidade de estrutura dentária coronária depende principalmente das propriedades mecânicas do material do núcleo e de seu desenho. A razão pela qual neste estudo foram utilizados elementos dentários sem nenhum remanescente coronário foi reproduzir "o pior cenário possível", ou seja, uma situação clínica extrema, em que, além de haver uma raiz enfraquecida, não será possível a obtenção do efeito férula.

O efeito da utilização de diversos sistemas de pinos de fibras sobre a resistência à fratura de dentes endodonticamente tratados e com raízes debilitadas foi um dos interesses do presente estudo (Tabela 5.1 e Figura 5.1). Sob as condições deste estudo, o grupo 1 (controle), restaurado com núcleos metálicos fundidos totalmente adaptados ao conduto radicular, foi o que alcançou os maiores valores de resistência à fratura $(110,85 \mathrm{kgf})$. Os grupos que atingiram os menores valores foram o grupo 2 (pinos de fibras de vidro de diâmetro menor que o do conduto, envolvidos apenas por cimento resinoso), com média de 76,04kgf, e o grupo 3 (pino de fibras de vidro de diâmetro menor que o do conduto, envolvidos por fitas de fibras de vidro), com média de 79,07kgf. Em um patamar intermediário, localizaram-se o grupo 4 (pino de fibras de vidro de diâmetro menor que o do conduto, combinado com pinos de 
fibras de vidro acessórios), com média de 93,88kgf, e o grupo 5 (pino anatômico), com média de $89,34 \mathrm{kgf}$.

Em uma análise mais detalhada dos valores de resistência à fratura, observou-se que, apesar de todo o cuidado tomado em cada um dos passos para garantir a padronização das técnicas utilizadas, houve variabilidade dos resultados obtidos dentro de um mesmo grupo. Ao se trabalhar com dentes naturais, deve-se levar em consideração as diferentes razões que podem contribuir para a variabilidade (e conseqüentemente para o desvio padrão), como: (1) grau de calcificação dos dentes; (2) pequenas variações na dimensão dos dentes, bem como na localização e forma dos condutos radiculares; (3) variações na dentina causadas por diferença no conteúdo de água, condições pulpares antes da extração e idade do paciente; (4) presença de micro-fraturas na dentina; e (5) influência do preparo manual dos corpos de prova; todos estes fatores, em última análise, são importantes para replicar a realidade clínica ${ }^{6,54,94}$. Além disso, podem ter ocorrido variações inerentes à utilização de técnicas adesivas altamente sensíveis; variação na quantidade e distribuição do cimento nos condutos alargados; permanência de resíduos de guta-percha ou de cimento endodôntico em áreas retentivas dos condutos e diferença na quantidade de micro-bolhas ou lacunas no cimento. Finalmente, no grupo 3 houve dificuldade em padronizar a proporção entre as fitas de fibras e o cimento resinoso, bem como a distribuição das fitas de fibras no interior do cimento.

No entanto, apesar de diferentes do ponto de vista numérico, o comportamento experimental dos grupos restaurados com fibras de vidro (grupos 2 a 5) pode ser considerado semelhante, independentemente do sistema usado, o que sugere que a resistência e o padrão de fratura vistos clinicamente com as formas de reconstrução testadas nestes grupos geralmente será similar.

Após os valores de resistência à fratura terem sido submetidos à Análise de Variância a um critério (ANOVA), ficou demonstrado que existia diferença estatisticamente significativa entre os grupos (Tabela 5.3). O teste de Tukey permitiu a constatação de que houve diferença estatisticamente significativa $(p<0,05)$ entre 0 grupo 1 e o grupo 2, assim como entre o grupo 1 e o grupo 3 (Tabela 5.4A). 0 teste de Tukey revelou ainda que não houve diferença estatisticamente significativa entre os demais grupos quando comparados entre si. 
Os resultados obtidos permitem afirmar que todos os pinos testados apresentaram resistência suficiente para enfrentar os esforços mastigatórios, uma vez que a força de mordida na região anterior varia entre 17 a $27 \mathrm{~kg}$ na atividade funcional normal $^{76,129}$. Desta forma, a carga que foi necessária para provocar falhas em dentes reconstruídos com os sistemas de núcleos confeccionados com pinos de fibras de vidro (grupos 2 a 5) está acima daquela que é exercida clinicamente em situações habituais (excetuando-se os pacientes que exercem atividades parafuncionais). A viabilidade destes sistemas se torna ainda mais promissora se for considerado que foram simuladas situações de raízes debilitadas e sem nenhum remanescente coronário.

Deve-se salientar ainda que é complexa a comparação entre estudos laboratoriais, uma vez que inúmeros fatores da metodologia podem variar, como: forma e material dos pinos; agentes cimentantes; sistemas adesivos; material de reconstrução coronária; elemento dentário utilizado; dimensões dos dentes; variações no preparo do canal radicular; intensidade e velocidade da força aplicada, entre outros. A variação de um ou mais fatores pode alterar de forma importante os resultados do ensaio.

Um trabalho executado por BRAZ et al. ${ }^{16}$, em 2005, mostrou resistência à fratura de $74,11 \mathrm{kgf}$ restaurando caninos com raízes amplamente alargadas com um pino de fibras de vidro Reforpost e três pinos de fibras de vidro acessórios Reforpin, todos cimentados com cimento resinoso Variolink II; este valor foi pouco inferior ao encontrado no grupo 4 (93,88kgf) do presente trabalho, que foi restaurado de forma similar. A resistência à fratura relativamente menor observada no estudo de BRAZ et al. ${ }^{16}$ provavelmente ocorreu porque os autores utilizaram maior alargamento do canal radicular (3,5mm de diâmetro em toda a extensão do conduto) que nesta tese. Estes autores concluíram que o pino de fibras de vidro, combinado com pinos acessórios, deve ser o método de escolha para reforçar raízes debilitadas. O presente estudo corrobora essa afirmativa, já que este foi o tipo de reconstrução que atingiu a maior resistência entre os grupos experimentais. A utilização de pinos acessórios de fibras de vidro já tinha sido sugerida e aplicada por FELIPPE et al. ${ }^{32}$, em 2001.

Com a técnica que usou apenas o pino de fibras de vidro envolto por grande quantidade de cimento resinoso (grupo 2), houve a inserção de um grande volume de cimento em um único incremento, o que causa um alto estresse na 
interface adesiva devido à contração de polimerização elevada, podendo diminuir a resistência de união do cimento resinoso às paredes do conduto. Além disso, nesta situação é mais difícil controlar a formação de micro-bolhas e até mesmo de grandes lacunas no cimento, as quais quase certamente serão numerosas. Foi provavelmente devido a estes fatores que o grupo 2 apresentou o maior desvio padrão entre aqueles reconstruídos com fibras de vidro (grupo 2 ao grupo 5). Obviamente, não se pretende recomendar para utilização clínica o procedimento utilizado no grupo 2 , sendo que este representou, no presente trabalho, uma situação indesejável que deve-se buscar contornar empregando outras técnicas restauradoras.

No grupo 3, foram utilizadas fitas de fibras de vidro com a mesma função dos pinos acessórios, ou seja, diminuir a espessura da película de cimento resinoso e aumentar a quantidade de fibras de reforço. SIRIMAI; RIIS; MORGANO ${ }^{119}$, em 1999, já haviam observado que o envolvimento de pinos metálicos de diâmetro menor que o do conduto com fitas de polietileno aumentou a resistência à fratura de raízes despolpadas em relação à utilização isolada destes pinos em condutos de maior diâmetro que o dos pinos, e também em relação à utilização de pinos formados unicamente com fitas de fibras de polietileno e cimento resinoso; além disso, foi evidenciado um menor número de fraturas radiculares com a utilização de pinos metálicos associados às fitas de polietileno que com núcleos metálicos fundidos.

Uma outra vantagem das fitas utilizadas no presente estudo (Interlig) é que são fornecidas pré-impregnadas com resina, não necessitando de aplicação adicional de adesivo e diminuindo o risco de contaminação da superfície das fibras ${ }^{14}$. É de fundamental importância uma adequada impregnação das fibras pela resina para a maior resistência do compósito por elas reforçado ${ }^{28}$.

A idéia de associar um pino de fibras de vidro com fitas de fibras para reduzir espaços vazios em condutos alargados foi sugerida pela primeira vez por $\mathrm{KIMMEL}^{67}$, em 2000, que utilizou fibras de polietileno para esta finalidade (de forma similar à técnica sugerida por SIRIMAI; RIIS; MORGANO ${ }^{119}$, em 1999, que associou fibras de polietileno a pinos metálicos). $\mathrm{KIMMEL}^{67,68}$ afirmou que este tratamento proporcionaria suporte e reforço interno para a raiz debilitada, através da formação de um monobloco adesivo estável, que deteria trincas e microfraturas existentes, prevenindo sua extensão até o periodonto e possibilitando o aproveitamento da raiz enfraquecida. 
Sobre o procedimento aplicado no grupo 5, GRANDINI ${ }^{49}$, em 2003, observou que é possível adaptar um pino de fibras pré-fabricado à forma do canal ovóide ou alargado pelo reembasamento do pino com resina composta. Desta forma, obtém-se um "pino anatômico", que reproduz com exatidão a morfologia do canal e proporciona a interposição de uma delgada espessura de cimento entre o pino e a parede do conduto.

De acordo com GRANDINI; SAPIO; SIMONETTI ${ }^{50}$, ainda em 2003, a técnica do pino anatômico deve ser utilizada como rotina clínica para condutos de formato irregular ou alargados, podendo ser indicada sempre que a adaptação do pino pré-fabricado ao conduto for inadequada. Outra vantagem da técnica é que a mesma não necessita de envolvimento laboratorial. Através de microscopia eletrônica de varredura, verificou-se que com os pinos anatômicos a espessura do cimento resinoso é cerca de seis vezes menor que com pinos pré-fabricados, havendo conseqüentemente uma redução significativa do número e da dimensão de microbolhas no cimento ${ }^{49}$. Quanto menor a espessura da película de cimento, mais uniforme é a distribuição das cargas oclusais e menor a contração de polimerização do cimento resinoso, prevenindo falhas adesivas e deslocamento precoce do pino ${ }^{49,50}$.

Diversos autores ${ }^{74,75,114,134}$ observaram que a reconstrução interna de raízes com paredes finas utilizando-se resina composta aumenta a resistência à fratura do remanescente dentário; porém, é difícil conseguir a polimerização completa da resina composta nas regiões mais apicais do conduto ${ }^{71,139}$. Neste sentido, uma das vantagens do pino anatômico é a possibilidade de sua remoção do conduto para complementar a polimerização do cimento resinoso aderido ao pino. A conversão incompleta do cimento resinoso ou da resina composta pode comprometer as suas propriedades físicas e a resistência de união à dentina.

A eficácia da técnica do pino anatômico deve ser avaliada em estudos clínicos longitudinais ${ }^{49}$, inexistentes até a execução do presente estudo. É provável, porém, que a reprodução exata do formato do conduto e a íntima adaptação a este favoreça a retenção deste tipo de pinos ${ }^{50}$. Já podem ser encontrados na literatura relatos clínicos da utilização do pino anatômico ${ }^{50}$.

Porém, o fato de que não houve diferença estatística significativa entre a técnica do pino anatômico e as demais formas de reconstrução com pinos de fibras de vidro não a torna uma indicação absoluta, embora seja importante observar que a 
resistência à fratura obtida com o pino anatômico foi próxima daquela alcançada com núcleos metálicos fundidos no presente estudo. Além disso, a maioria das falhas observadas com a utilização de pinos anatômicos seriam clinicamente reparáveis, sem prejuízo para o remanescente dentário (Tabela 5.5 e Tabela 5.6). O tempo de trabalho para a confecção do pino anatômico é longo, devido ao emprego de uma resina composta fotopolimerizável.

Deve-se observar, porém, que do ponto de vista da praticidade, é mais provável que a classe odontológica prefira adotar a técnica do grupo 4 (utilização dos pinos de fibras de vidro acessórios) do que a técnica do pino anatômico, pois a segunda é mais difícil de ser executada e dispende um maior tempo clínico que a primeira.

Os excelentes valores de resistência à compressão encontrados na presente pesquisa com o emprego de pinos de fibras de vidro FibreKor (grupo 2 ao grupo 5) podem estar, em parte, relacionados à própria composição destes pinos: $42 \%$ de fibras de vidro, $29 \%$ de carga e $29 \%$ de resina composta, a qual exerce a função de matriz resinosa ${ }^{92,127}$. Este pino obedece à recomendação da literatura de que um compósito reforçado por fibras deve possuir uma quantidade de fibras na resina de pouco menos que $50 \%$ do volume total para atingir um módulo de elasticidade suficientemente alto para suportar as cargas oclusais ${ }^{32,41}$. Para núcleos de preenchimento com pinos de fibras, é essencial controlar a proporção entre as fibras e o compósito, pois há relação direta desta proporção com a resistência à fratura do elemento dentário ${ }^{92}$.

Os resultados obtidos neste estudo indicam que as técnicas testadas permitiram a obtenção de uma proporção adequada entre fibras e resina. O grupo 2 apresentou a menor resistência entre os grupos que utilizaram fibras de vidro, provavelmente por ser aquele com a menor quantidade de fibras no interior do conduto em relação ao cimento resinoso. Embora a maior resistência com fibras de vidro tenha sido obtida com o grupo 4 (pino de fibras de vidro combinado com pinos acessórios), FERRARI ${ }^{33}$, em 2005, cogitou a possibilidade de que com este tipo de procedimento a alta quantidade de fibras em proporção ao cimento resinoso poderia prejudicar a adesão do cimento às paredes do canal. No entanto, não foram observadas falhas adesivas com as técnicas utilizadas no grupo 4 , nem com as outras técnicas que utilizaram pinos de fibras. 
Raciocinando somente do ponto de vista da resistência à fratura, um clínico iniciante poderia dar preferência aos núcleos metálicos fundidos ao invés de reconstruções com fibras de vidro, uma vez que os primeiros alcançaram maiores valores de resistência, assim como em diversas outras pesquisas comparando-os com outros tipos de pinos pré-fabricados ${ }^{13,29,38,116,119}$. Porém, vários autores não encontraram diferenças significativas na resistência entre núcleos metálicos fundidos e núcleos de preenchimento com materiais variados ${ }^{18,53,54,58,84,106}$. Além disso, a avaliação do conjunto de artigos revisados indica que os pinos de fibras, tanto aqueles pré-fabricados quanto os confeccionados diretamente no conduto, apresentam um padrão de falhas muito mais favorável (fraturas reparáveis) que o de núcleos metálicos fundidos, pinos pré-fabricados metálicos ou pinos cerâmicos ${ }^{13,18,29,38,53,54,58,84,106,116,119}$, indo ao encontro do padrão de falha observado nesta tese (Tabela 5.5 e Tabela 5.6).

Deve ser enfatizado que, desde que a reconstrução possua uma resistência à fratura clinicamente aceitável, um padrão de falhas favorável é mais importante que uma alta resistência à fratura. A revisão da literatura desta tese permitiu uma ampla confirmação de que o comportamento mecânico e o padrão de falhas dos pinos de fibras são diversos dos pinos metálicos e cerâmicos, com vantagem para os primeiros ${ }^{13,18,29,38,53,54,58,84,106,116,119}$. Os pinos metálicos tendem a produzir a fratura irreparável da raiz, enquanto com os pinos de fibras a fratura radicular, quando ocorre, é usualmente localizada mais cervicalmente e de mais fácil reparo. O padrão de fratura desfavorável que ocorre com os pinos metálicos e cerâmicos é principalmente devido à sua grande rigidez (alto módulo de elasticidade em relação ao da dentina), que causa uma elevada concentração de estresse na dentina radicular ${ }^{1,14,26,27,32,40,41,76,116}$ e à necessidade de remoção de maior quantidade de estrutura dentária quando núcleos metálicos fundidos são confeccionados ${ }^{84}$.

No presente estudo, a falha predominante no grupo 1 foi a fratura ao nível do terço médio da raiz $(60 \%)$, seguida pela fratura no terço cervical da raiz (30\%). Este foi o único grupo em que aconteceu uma fratura radicular longitudinal; este tipo de fratura não ocorreu nos demais grupos. No conjunto, houve $70 \%$ de fraturas irreparáveis no grupo 1 , enquanto nos demais grupos este valor nunca foi maior que $30 \%$, o que pode ser considerado como um fato realmente positivo.

O padrão de falha visto com os núcleos metálicos fundidos no grupo 1 ficou bem conhecido através de diversas pesquisas executadas a partir da década de 
$1980^{18,22,40,69,81,116,119,120,131}$, sendo caracterizado por um alto número de fraturas irreparáveis, que inclui fraturas oblíquas estendendo-se até o terço médio ou apical radicular, bem como fraturas longitudinais da raiz.

No grupo 2, $40 \%$ das falhas ocorreram por flexão ou fratura do pino e/ou da porção coronária do núcleo (provocando deslocamento parcial da coroa); houve igual porcentagem de fraturas no terço cervical da raiz, que não inviabilizariam o reaproveitamento do dente. As demais falhas (20\%) foram fraturas no terço médio da raiz.

No grupo 4, o número de falhas por flexão ou fratura do pino e/ou da porção coronária do núcleo foi próximo ao do grupo 2, assim como o número de fraturas do terço médio da raiz ( $30 \%$ de cada tipo de falha). A maioria das falhas ocorreram por fratura no terço cervical da raiz (40\%).

No grupo 3, houve mais fraturas no terço cervical da raiz $(60 \%)$ que nos demais grupos de dentes restaurados com fibras de vidro. A segunda falha mais comum foi por flexão ou fratura do pino (30\%). Ocorreu apenas uma falha por fratura no terço médio radicular. Pôde-se observar que no grupo 3 o número de fraturas radiculares (seis fraturas no terço cervical e uma fratura no terço médio da raiz) foi maior do que aquele observado em estudos nos quais o pino foi confeccionado unicamente com fitas de fibras ${ }^{29,92}$, provavelmente porque o núcleo se torna mais rígido quando as fitas são combinadas com um pino de fibras de vidro do que quando utilizadas isoladamente.

A característica principal do grupo 5 (pino anatômico) foi que metade das falhas aconteceu por flexão ou fratura do pino e/ou da porção coronária do núcleo. As demais falhas foram por fratura no terço cervical da raiz $(30 \%)$ ou no terço médio da raiz (apenas $20 \%$ dos espécimes).

Ao se analisar os resultados acima, observa-se que o grupo 3 apresesentou a maior quantidade de espécimes com padrão de fratura favorável (90\%), seguido pelo grupo 2 e grupo 5 (ambos com 80\%), grupo 4 (com 70\%) e grupo 1 (apenas $30 \%$ de falhas favoráveis). Desta forma, embora os grupos 2 e 3 tenham apresentado menor resistência que os demais grupos, seu padrão de falhas foi muito favorável. 
Nas Figuras 6.1A, 6.1B e 6.1C podem ser observados os tipos de fraturas que ocorreram mais usualmente neste estudo.

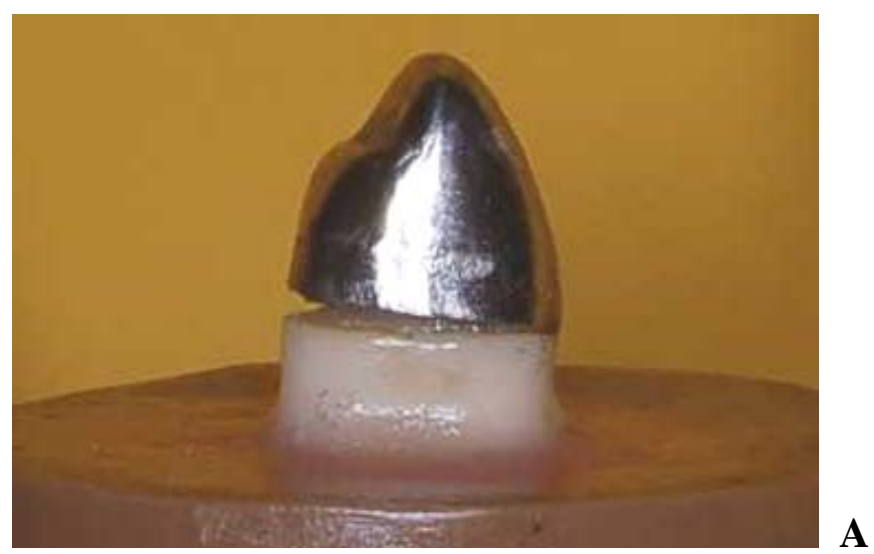

A

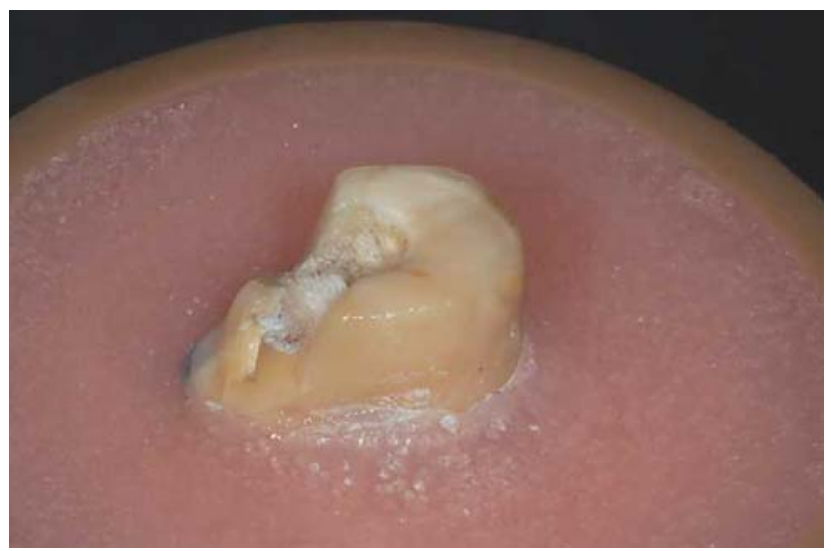

B

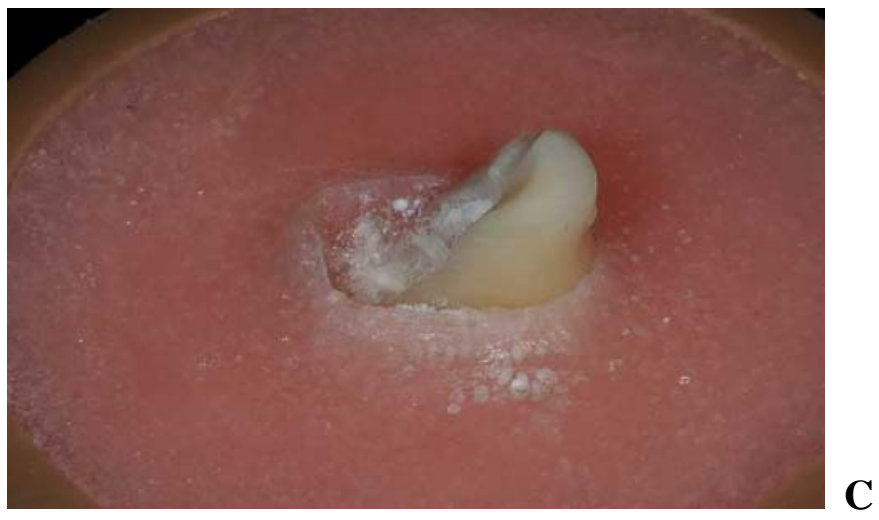

FIGURA 6.1 - Tipos de fraturas mais comuns:

A) Flexão ou fratura da porção coronária do núcleo, acompanhada de deslocamento parcial da coroa

B) Fratura ao nível do terço cervical da raiz (no limite do nível ósseo simulado)

C) Fratura radicular ao nível do terço médio da raiz (abaixo do nível ósseo simulado) 
Quanto ao grupo 2, foi surpreendente que tenha sido observado um padrão de falhas favorável, mesmo com uma espessa camada de cimento resinoso. É verdade que o módulo de elasticidade do cimento resinoso em torno do pino é similar ao da dentina e ao módulo do pino de fibras ${ }^{99}$; além disso, BERGER; CAVINA ${ }^{12}$, em 2004, afirmaram que os cimentos resinosos proporcionam retenção e resistência adequada mesmo em camadas espessas, o que é importante quando se utilizam pinos pré-fabricados em condutos alargados, já que estes geralmente não se adaptam precisamente ao conduto. Porém, ainda existe o problema da alta contração de polimerização associada a camadas espessas de cimento resinoso e o estresse por ela provocado, que poderia exceder a resistência adesiva e provocar gaps na interface cimento-dentina; em uma situação como esta, é provável que o deslocamento do pino ocorreria a curto ou médio prazo ${ }^{49}$. Por outro lado, o grupo 5 (pinos anatômicos) apresentou o mesmo número de falhas favoráveis que o grupo 2, mesmo com uma película de cimento bem menos espessa que a deste último.

Dentre os grupos de dentes reconstruídos com fibras, o grupo 4 foi o que apresentou a maior resistência e também o maior número de fraturas desfavoráveis (30\% de fraturas no terço médio da raiz). Segundo FREILICH et al. ${ }^{41}$, em 2000 , uma quantidade de fibras na resina próxima a $50 \%$ do volume total permite a obtenção de um módulo de elasticidade suficientemente alto para suportar as cargas oclusais. É possível que, com a utilização dos pinos acessórios neste grupo, a quantidade de fibras em relação ao cimento resinoso tenha aumentando consideravelmente a rigidez do núcleo de preenchimento e a tendência à fratura radicular.

$\mathrm{Na}$ presente pesquisa, o fato de não terem ocorrido falhas por deslocamento dos núcleos foi possivelmente devido à uma associação de vários fatores, tais como: 1) uma resistência adesiva suficiente entre o cimento resinoso e a dentina, bem como entre o cimento resinoso e o pino; 2) compatibilidade química entre o cimento resinoso e o sistema adesivo de três passos, ambos de cura dual; 3) a silanização do pino de fibras previamente à cimentação, proporcionando ganho significativo da adesão entre pino e resina ${ }^{47}$; 4) a configuração favorável do pino (pararelo com ápice cônico e macro-retenções superficiais em toda sua extensão); 5) a ótima adesão entre a matriz de resina composta dos pinos de fibras de vidro utilizados e o cimento resinoso ${ }^{34}$. 
É essencial que o sistema adesivo seja compatível com o cimento resinoso. Uma vez que a polimerização de cimentos resinosos de polimerização química ou dual (como o RelyX ARC, utilizado nesta pesquisa) é prejudicada pela associação com adesivos convencionais simplificados (dois passos) ou com adesivos autocondicionantes de passo único, devido à acidez elevada destes sistemas, deve-se preferencialmente utilizar com estes cimentos um adesivo convencional de três passos $^{12}$.

A opção por um sistema adesivo de cura dual favoreceu sua polimerização, pois o acesso da luz do fotopolimerizador nas regiões mais apicais do conduto é limitado ${ }^{71,139}$. A ausência de falhas por deslocamento do pino indicou que a combinação de cimentos resinosos e agentes adesivos selecionados para o estudo proporcionou uma adesão suficiente na interface cimento-dentina. Por outro lado, a utilização do mesmo agente adesivo em todos os grupos possibilitou a eliminação de variáveis.

O silano possui a capacidade de incrementar significativamente a adesão entre os pinos de fibras e o cimento resinoso ${ }^{47}$.

Ainda quanto à questão do modo de falha, observou-se nos grupos 2 a 5 que quando os pinos de fibras flexionaram ou sofreram fratura (quase sempre incompleta ou em "galho verde") devido ao dobramento e deformação plástica sob cargas de compressão, era comum que ocorresse simultaneamente a fratura da porção coronária do núcleo e o deslocamento parcial da coroa. Deve-se salientar, porém, que a perda do selamento da coroa, que seria acompanhada de microinfiltração e do desenvolvimento de processos cariosos, só ocorreu com cargas superiores às que normalmente ocorrem na cavidade oral (acima de $30 \mathrm{kgf}$ ).

Poder-se-ia supor que as características elásticas dos pinos de fibras facilitariam sua movimentação no interior do conduto e o surgimento de micro-fraturas no cimento resinoso ou na resina de preenchimento coronário, levando à perda de selamento da coroa e falha precoce da restauração ${ }^{89}$, especialmente quando a férula é mínima ou não há remanescente coronário. Apesar de não terem sido encontrados estudos clínicos que corroborassem esta hipótese na revisão de literatura, pesquisas futuras deverão tentar esclarecer o papel da flexibilidade dos pinos de fibras e da quantidade de remanescente dentário sobre a micro-infiltração coronária e sobre a longevidade de restaurações com pinos de fibras. 
A maioria dos autores considera o fato dos pinos de fibras possuírem módulo de elasticidade bastante próximo ao da dentina como sua maior vantagem em relação aos núcleos metálicos fundidos, pinos metálicos pré-fabricados e pinos cerâmicos, sendo praticamente unânimes em afirmar que os pinos de fibras proporcionam a absorção do estresse e sua distribuição uniforme para a estrutura radicular do remanescente dentário ${ }^{5,26,39,40,41,60,94,99,110,116}$. Assim, se forem aplicadas cargas excessivas ao elemento dentário, os pinos de fibras serão capazes de reduzir o risco de fratura da raiz ${ }^{35,41}$, o que foi confirmado por diversos estudos clínicos ${ }^{35,39,78,87,91}$ e laboratoriais ${ }^{18,22,40,69,81,116,119,120}$.

Outras características favoráveis dos pinos de fibras incluem biocompatibilidade, ausência de corrosão e fácil remoção (existindo inclusive kits desenvolvidos para esta finalidade $)^{5,100,110,127}$. Além disso, quando estes pinos são usados para a restauração de dentes despolpados, a porção coronária é reconstruída com resina composta, que proporciona certas vantagens, como: estética; permite o preparo coronário na mesma consulta; e adere aos pinos e coroas quando usadas técnicas adesivas apropriadas.

Acredita-se também que pinos de cor similar àquela dos dentes naturais resultam em melhor estética quando utilizados sob coroas livres de metal, uma vez que os pinos metálicos podem causar manchamento e sombreamento na porção cervical da raiz, principalmente em pacientes com tecido periodontal fino ou linha de sorriso alta ${ }^{35,57,64}$. Neste sentido, é importante observar que, apesar da excelente estética proporcionada pelos pinos cerâmicos, sua dureza e alto módulo de elasticidade estão associadas com a friabilidade destes pinos e com fraturas dentárias desfavoráveis ${ }^{3,18,76}$, além de serem muito difíceis de remover do conduto, quando necessário. Assim, os pinos de fibras de vidro ou quartzo devem ser a primeira escolha para a reconstrução de dentes despolpados quando a estética é primordial.

A restauração de dentes endodonticamente tratados ainda pode ser considerada um desafio, suscitando muitas controvérsias e dúvidas. Tal desafio apresenta proporções ainda maiores quando se trata da restauração de dentes com condutos alargados. Não existe uma opinião única sobre a forma ideal de recuperar dentes nestas condições. Muitas vezes não há base científica para auxiliar a determinar a indicação mais correta de determinada técnica para uma situação específica. A restauração ideal deve permitir a recuperação tanto da função quanto da 
estética, fornecendo um prognóstico favorável e seguro a longo prazo. Além disso, o procedimento empregado deve ser o mais conservador possível, uma vez que nenhum material restaurador substitui o tecido dental com a mesma eficiência, de forma que este deve ser poupado tanto quanto possível.

Os valores de resistência à fratura e o padrão de falha favoráveis observados com as técnicas aplicadas no grupo 3, 4 e 5 (uma vez que o grupo 2 representa uma situação a ser evitada, se possível) sugerem que as mesmas são alternativas viáveis para a reconstrução estética e para a recuperação funcional de dentes com condutos amplos, os quais de outra forma provavelmente seriam condenados à extração. Deve-se ressaltar que a resistência à fratura alcançada no grupo 1 (110,85kgf), com a utilização de núcleos metálicos fundidos, foi similar, do ponto de vista estatístico, à resistência encontrada nos grupos 4 (93,88kgf) e 5 $(89,34 \mathrm{kgf})$. Estes resultados corroboraram as observações de vários autores de que os pinos fibro-resinosos permitem a absorção do estresse, distribuindo-o uniformemente nas estruturas radiculares e minimizando assim o risco de fraturas da raiz, especialmente das longitudinais ${ }^{18,22,35,39,40,69,78,81,87,91,116,119,120}$. É provável que a adesão de todos os materiais de reconstrução (pino de fibras, cimento resinoso e resina composta de preenchimento coronário) entre si e com a estrutura dentária também tenha sido importante na obtenção de tais resultados.

Certamente, é mais fácil de controlar todos os passos da técnica adesiva em laboratório que intra-oralmente, especialmente quando não existe a possibilidade de empregar o isolamento absoluto. Desta forma, é muito provável que a resistência de união obtida clinicamente seja menor que aquela alcançada em estudos in vitro. Além disso, algumas situações podem afetar a integridade da adesão a longo prazo, devido ao contato indesejado com a umidade: 1, falha adesiva entre a resina composta da porção coronária do núcleo e a estrutura dentária; 2, ocorrência de cárie secundária; e 3) absorção de água pelo agente adesivo ou pela resina composta da porção coronária do núcleo. De fato, estudos clínicos ${ }^{35,39,78,87,91}$ têm mostrado que o deslocamento do pino é a falha mais freqüente em dentes reconstruídos com pinos de fibras. De acordo com BERGER; CAVINA ${ }^{12}$, em 2004, os insucessos com pinos de fibras estão relacionados a falhas de cimentação ou à utilização em dentes com menos de $2 \mathrm{~mm}$ de remanescente coronário. Além disso, um estudo in vitro também demonstrou que a resistência de pinos de fibras de carbono, 
de quartzo ou de vidro diminuiu pelo contato prolongado com a água, tornando-se mais propensos à fratura ${ }^{77}$.

Apesar dos bons resultados observados, antes que os procedimentos restauradores testados nos grupos 3, 4 e 5 venham a ser indicados para uso rotineiro na clínica diária, serão necessárias avaliações clínicas controladas para avaliar seu desempenho a longo prazo, bem como estudos laboratoriais adicionais para avaliar outras propriedades mecânicas destes sistemas de núcleos. Enquanto tais pesquisas confirmando a segurança e previsibilidade destes sistemas não forem executadas, deve-se evitar sua indicação em situações de risco aumentado, tais como: 1) bruxismo ou outras formas de parafunção; 2) pilares de prótese parcial removível com extensão distal; 3) pilares de prótese parcial fixa com espaço edêntulo longo ou com elementos em cantilever; 4) situações de oclusão desfavorável, como trespasse vertical acentuado. Recomenda-se ainda muita prudência na utilização em condutos exageradamente amplos (paredes radiculares com $0,5 \mathrm{~mm}$ de espessura na região cervical ou menos), situação em que o prognóstico do elemento dentário a longo prazo é desfavorável. Se estes sistemas forem utilizados nas circunstâncias acima descritas, uma taxa de sobrevivência mais baixa deve ser esperada.

Além disso, é preciso cautela na extrapolação das conclusões de estudos in vitro diretamente para uma situação clínica. Deve-se considerar, especialmente, a impossibilidade de reproduzir em laboratório as forças funcionais e parafuncionais das mais diferentes direções e intensidades a que estão submetidos os elementos dentários na cavidade oral. Este fato se torna ainda mais importante porque os pinos de fibras são anisotrópicos, ou seja, suas propriedades mecânicas e, por conseguinte, seu comportamento variam de acordo com a direção da carga ${ }^{14,41}$. Por exemplo, o módulo de elasticidade dos pinos de fibras de carbono varia de 8GPa a 110GPa. Em um ângulo de incidência de $90^{\circ}$ com o longo eixo do pino, o módulo é de $8 \mathrm{GPa}$ (próximo ao da dentina radicular); em um ângulo de incidência de 20 a $45^{\circ} \mathrm{com}$ o longo eixo, o módulo é de 18 a 30GPa (próximo ao da dentina); e em um ângulo de incidência de $0^{\circ}$, o módulo é de 100 a $110 \mathrm{GPa}^{78}$. No presente estudo, a carga de compressão foi aplicada em $135^{\circ} \mathrm{com}$ o longo eixo do dente, simulando uma condição clínica de oclusão do tipo classe I; porém, na cavidade oral a carga pode ser aplicada nas mais variadas direções sobre o elemento dentário, especialmente nos movimentos excursivos. 
Uma das limitações deste estudo é a incerteza sobre a completa polimerização do cimento resinoso na porção mais apical do conduto. LE BELL et al. ${ }^{71}$, em 2003, afirmaram que o principal requisito para o sucesso de pinos de fibras de vidro confeccionados diretamente no conduto com fitas de fibras é obter um grau de conversão suficiente do cimento resinoso. Assim, são recomendados estudos adicionais para mensurar o grau de conversão de cimentos resinosos com as técnicas utilizadas neste estudo.

Também é preciso realizar ensaios variando a quantidade de remanescente coronário, para avaliar o papel do efeito férula sobre a resistência dentária e o padrão de falhas com os procedimentos restauradores aplicados neste estudo. Finalmente, é especialmente importante que futuramente sejam executadas pesquisas com diferentes graus de alargamento do conduto, para verificar qual o limite de perda de estrutura dentária em que as técnicas aqui testadas ainda funcionarão adequadamente.

O presente estudo sugere que o procedimento restaurador de escolha para a restauração de dentes tratados endodonticamente com raízes debilitadas deve ser aquele proposto e avaliado no grupo 4 (pino de fibras de vidro convencional associado a pinos de fibras de vidro acessórios), que proporcionou a obtenção de valores de resistência à fratura bem acima do minímo necessário para pacientes com atividade funcional normal ${ }^{76,129}$, bem como um padrão de fratura muito favorável para a manutenção do remanescente dentário. Além disso, esta técnica é mais fácil e rápida de ser executada, menos susceptível a erros e menos sensível tecnicamente do que aquelas sugeridas nos grupos 2, 3 e 5. Por outro lado, são necessários para sua execução apenas materiais de fácil acesso na clínica diária e de custo relativamente baixo, sem nenhum envolvimento laboratorial. Considerando estes atributos, é possível prever o sucesso clínico desta promissora técnica com maior certeza que para os demais procedimentos restauradores avaliados nesta tese, desde que estudos de acompanhamento clínico longitudinal confirmem sua viabilidade. 
7 CONCLUSÕES 


\section{CONCLUSÕES}

Buscando-se elucidar a proposição inicial através da metodologia estabelecida e após a aplicação da análise estatística aos valores obtidos neste estudo, pôde-se concluir que:

1. A resistência à fratura sob carga compressiva mostrou-se estatisticamente semelhante entre os dentes reconstruídos com núcleos metálicos fundidos, com pinos anatômicos e com pinos de fibras de vidro combinados com pinos acessórios.

2. Houve diferença estatisticamente significativa entre os dentes reconstruídos com núcleos metálicos fundidos e aqueles reconstruídos com pinos de fibras de vidro e cimento resinoso ou com pinos de fibras de vidro e fitas de fibras de vidro.

3. Os dentes reconstruídos com núcleos metálicos fundidos apresentaram $70 \%$ das fraturas desfavoráveis.

4. Os dentes reconstruídos com diferentes procedimentos restauradores empregando pinos de fibras de vidro apresentaram padrão de fraturas variado, nunca ultrapassando $30 \%$ de fraturas desfavoráveis. 
REFERÊNCIAS BIBLIOGRÁFICAS 


\section{REFERÊNCIAS BIBLIOGRÁFICAS}

1. ALBUQUERQUE, R. C. Pinos intra-radiculares pré-fabricados. In: CARDOSO, R. J. A.; GONÇALVES, E. A. N. (Coord). Oclusão/ATM, prótese sobre implantes e prótese bucomaxilofacial. São Paulo: Artes Médicas, 2002. Cap. 19, p. 441-462.

2. ALBUQUERQUE, R. C. et al. Stress analysis of an upper central incisor restored with different posts. J Oral Rehabil, Oxford, v. 30, n. 9, p. 936-943, Sept. 2003.

3. AKKAYAN, B. An in vitro study evaluation the effect of ferrule length on fracture resistance of endodontically treated teeth restored with fiber-reinforced and zirconia dowel systems. J Prosthet Dent, Saint Louis, v. 92, n. 2, p. 155-162, Aug. 2004.

4. AKKAYAN, B.; GÜLMEZ, T. Resistance to fracture of endodontically treated teeth restored with different post systems. J Prosthet Dent, Saint Louis, v. 87, n. 4, p. 431-437, Apr. 2002.

5. ASMUSSEN, E.; PEUTZFELDT, A.; HEITMANN, T. Stiffness, elastic limit, and strength of newer types of endodontic posts. J Dent, Bristol, v. 27, n. 4, p. 275278, May 1999.

6. ASSIF, D. et al. Effect of post design on resistance to fracture of endodontically treated teeth with complete crowns. J Prosthet Dent, Saint Louis, v. 69, n.1, p. 36-40, Jan. 1993.

7. BAE, J-M. et al. The flexural properties of fiber-reinforced composite with lightpolymerized polymer matrix. Int J Prosthodont, Lombard, v. 14, n. 1, p. 33-39, Jan./Feb. 2001.

8. BARABAN, D. J. The restoration of pulpless teeth. Dent Clin North Am, Philadelphia, p. 633-653, Nov. 1967.

9. BARABAN, D. J. A simplified method for making post and cores. J Prosthet Dent, Saint Louis, v. 24, n. 3, p. 287-297, Sept. 1970.

10. BARABAN, D. J. Immediate restoration of pulpless teeth. J Prosthet Dent, Saint Louis, v. 28, n. 6, p. 607-612, Dec. 1972.

11. BARKHORDAR, R. A.; RADKE, R.; ABBASI, J. Effect of metal collars on resistance of endodontically treated teeth to root fracture. J Prosthet Dent, Saint Louis, v. 61, n. 6, p. 676-678, June 1989.

12. BERGER, C. R.; CAVINA, D. A. Pinos intra-radiculares não-metálicos. In: GOMES, J. C. (Coord). Estética em clínica odontológica. Curitiba: Ed. Maio, 2004. Cap. 12, p. 395-426. 
13. BONILLA, M. E. G. Avaliação da resistência à fratura transversal de raízes amplamente destruídas reconstruídas com núcleos. 2001. $110 \mathrm{f}$. Dissertação (Mestrado em Odontologia) - Faculdade de Odontologia de Bauru, Universidade de São Paulo, Bauru, 2001.

14. BOTTINO, M. A. et al. Materiais poliméricos. In: Estética em reabilitação oral metal free. São Paulo: Artes Médicas, 2001. Cap. 6, p. 348379.

15. BOUDRIAS, P.; SAKKAL, S.; PETROVA, Y. Anatomical post design meets quartz fiber technology: rationale and case report. Comp Continuing Educ Dent, Lawrenceville, v. 22, n.4, p. 337-340, Apr. 2001.

16. BRAZ, R. et al. Evaluation of reinforcement materials used on filling of weakened roots. J Dent Res, Chicago, v. 84, p. 112, Mar. 2005. Special issue. Abstract $n$. 1733. Trabalho apresentado na $83^{\mathrm{a}}$ Sessão Geral do IADR / AADR / CADR, Mar. 2005.

17. BURGESS, J. O.; DOUGLAS, A. S.; NORLING, B. K. Post retention in root filled teeth. J Dent Res, Chicago, v. 76, n. 1, p. 183, Jan. 1997. Abstract n. 1357.

18. BUTZ, F. et al. Survival rate and fracture strength of endodontically treated maxillary incisors with moderate defects restored with different post-and-core systems: an in vitro study. J Prosthet Dent, Saint Louis, v. 14, n. 1, p. 58-64, Jan./Feb. 2001.

19. CAPUTO, A. A.; STANDLE, J. P. Pins and posts - why, when, how. Dent Clin North Am, Philadelphia, v. 20, n. 2, p. 299-312, Apr. 1976.

20. COELHO SANTOS, G.; EL-MOWAFY, O.; RUBO, J. H. Diametral tensile strength of a resin composite core with nonmetallic prefabricated posts: an in vitro study. J Prosthet Dent, Saint Louis, v. 91, n. 4, p. 335-341, Apr. 2004.

21. COHEN, B. I. et al. Comparison of the retentive and photoelastic properties of two prefabricated endodontic post systems. J Oral Rehabil, Oxford, v. 26, n. 6, p. 488-494, June 1999.

22. CORMIER, C. J.; BURNS, D. R.; MOON, P. In vitro comparison of the fracture resistance and failure mode of fiber, ceramic, and conventional post systems at various stages of restoration. J Prosthodont, Philadelphia, v. 10, n. 1, p. 26-36, Mar. 2001.

23. DEAN, J. P.; JEANSONNE, B. G.; SARKAR, N. In vitro evaluation of a carbon fiber post. J Endod, Chicago, v. 24, n. 12, p. 807-810, Dec. 1998.

24. DIETSCHI, D.; ROMELLI, M.; GORETTI, A. Adaptation of adhesive posts and cores to dentin after fatigue testing. Int J Prosthodont, Lombard, v. 10, n. 6, p. 498-507, Nov./Dec. 1997.

25. DRUMMOND, J. L.; BAPPA, M. S. Static and cyclic loading of fiber-reinforced dental resin. Dent Mater, Copenhagen, v. 19, n. 3, p. 226-231, May 2003. 
26. DURET, B.; DURET, F.; REYNAUD, M. Long-life physical property preservation and postendodontic rehabilitation with the Composipost. Comp Continuing Educ Dent, Lawrenceville, v. 17, p. 565-573, 1996. Supplement 20.

27. DURET, P. B.; REYNAUD, M.; DURET, F. Un nouveau concept de reconstrution corono-radiculaire: le composiposte (I). Chir Dent Fr, Paris, v. 60, n.54, p. 131141, Nov. 1990 apud MANNOCCI, F. et al. ${ }^{77}$. p. 12-17.

28. ELLAKWA, A. E. et al. Influence of bonding agent composition on flexural properties of an ultra-high molecular weight polyethylene fiber-reinforced composite. Oper Dent, Seattle, v. 27, n. 2, p. 184-191, Mar./Apr. 2002.

29. ESKITAŞCIOĞLU, G.; BELLI, S.; KALKAN, M. Evaluation of two post core systems using two different methods (fracture strength test and a finite elemental stress analysis). J Endod, Chicago, v. 28, n. 9, p. 629-633, Sept. 2002.

30. FABRICATING a fiber-reinforced post \& core using GlasSpan ceramic fibers by GlasSpan, Inc. Dent Prod Rep, Northfield, v. 31, n. 1, p. 22-23, Apr. 1997.

31. FAUCHARD, P. Le chirurgien dentisté; ou, traité des dents. Paris: Jean Mariette, 1728 apud RING, M. E. ${ }^{98}$.

32. FELIPPE, L. A. et al. Fibras de reforço para uso odontológico - fundamentos básicos e aplicações clínicas. Rev Assoc Paul Cir Dent, São Paulo, v. 55, n. 4, p. 245-250, jul./ago. 2001.

33. FERRARI, M. Associação entre pinos de fibras de vidro pré-fabricados e pinos acessórios de fibras de vidro. Trabalho apresentado no Second Symposium of PH.D. Sister Schools: Aesthetic Restorative Materials Current Trends and Development, Bauru, out. 2005.

34. FERRARI, M.; VICHI, A.; GRANDINI, S. Efficacy of different adhesive techniques on bonding to root canal walls: an SEM investigation. Dent Mater, Copenhagen, v. 17 , n. 5, p. 422-429, Sept. 2001.

35. FERRARI, M. et al. Retrospective study of the clinical performance of fiber posts. Am J Dent, San Antonio, v. 12, p. 9B-13B, May 2000. Special issue.

36. FERRARI, M. et al. Bonding to root canal: structural characteristics of the substrate. Am J Dent, San Antonio, v. 13, n. 5, p. 255-260, Oct. 2000.

37. FERRARI, M. et al. Efficacy of a self-curing adhesive-resin cement system on luting glass-fiber posts into root canals: an SEM investigation. Int J Prosthodont, Lombard, v. 14, n. 6, p. 543-549, Nov./Dez. 2001.

38. FOKKINGA, W. A. et al. A structured analysis of in vitro failure loads and failure modes of fiber, metal, and ceramic post-and-core systems. Int J Prosthodont, Lombard, v. 17, n. 4, p. 476-482, July/Aug. 2004. 
39. FREDRIKSSON, M. et al. A retrospective study of 236 patients with teeth restored by carbon fiber- reinforced epoxy resin posts. J Prosthet Dent, Saint Louis, v. 80, n. 2, p. 151-157, Aug. 1998.

40. FREEDMAN, G. The carbon fiber post: metal-free, post-endodontic rehabilitation. Oral Health, Don Mills, v. 86, n. 2, p. 23-30, Feb. 1996.

41. FREILICH, M. A. et al. Fiber-reinforced composites in clinical dentistry. Chicago: Quintessence, 2000. 106 p.

42. FUSS, Z. et al. An evaluation of endodontically treated vertical root fractures teeeth : impact of operative procedures. J Endod, Chicago, v. 27, n. 1, p. 46-48, Jan. 2001.

43. GALHANO, G. A. et al. Evaluation of the flexural strength of carbon fiber -, quartz fiber -, and glass fiber-based posts. J Endod, Chicago, v. 31, n. 3, p. 209-211, Mar. 2005.

44. GLAZER, B. Restoration of endodontically treated teeth with carbon fiber posts a prospective study. J Can Dent Ass, Toronto, v. 66, n. 11, p. 613-618, Dec. 2000.

45. GOLDBERG, A. J.; BURSTONE, C. J. The use of continuous fiber reinforcement in dentistry. Dent Mater, Copenhagen, v. 8, n. 3, p. 197-202, May 1992.

46. GOLDBERG, A. J. et al. Flexure properties and fiber architecture of commercial fiber reinforced composites. J Dent Res, Chicago, v. 77, n. 2, p. 226, Mar. 1998. Abstract n. 967. Trabalho apresentado no $27^{\circ}$ Anual Meeting of the IADR / $22^{\text {nd }}$ CADR, Mar. 1998.

47. GORACCI, C. et al. The adhesion between prefabricated FRC posts and composite resin cores: microtensile bond strength with and without postsilanization. Dent Mater, Copenhagen, v. 21, n. 5, p. 437-444, May 2005.

48. GORACCI, C. et al. The contribution of friction to the dislocation resistance of bonded fiber posts. J Endod, Chicago, v. 31, n. 8, p. 608-612, Aug. 2005.

49. GRANDINI, S. O pino anatômico. In: SCOTTI, R.; FERRARI, M. (Coord). Pinos de fibra. São Paulo: Artes Médicas, 2003. Cap. 9, p. 93-98.

50. GRANDINI, S.; SAPIO, S.; SIMONETTI, M. Use of anatomic post and core for reconstructing an endodontically treated tooth: a case report. J Adhes Dent, New Malden, v. 5, n. 3, p. 243-247, Fall 2003.

51. GRANDINI, S. et al. A one step procedure for luting glass fibre posts: an SEM evaluation. Int Endod J, Oxford, v. 37, n. 10, p. 679-686, Oct. 2004.

52. GUZY, G. E.; NICHOLLS, J. I. In vitro comparison of intact endodontically treated teeth with and without endo-post reinforcement. J Prosthet Dent, Saint Louis, v. 42, n. 1, p. 39-42, July 1979. 
53. HEYDECKE, G.; PETERS, M. C. The restoration of endodontically treated, single-rooted teeth with cast or direct post and cores: a sistematic review. J Prosthet Dent, Saint Louis, v. 87, n. 4, p. 380-386, Apr. 2002.

54. HEYDECKE, G. et al. Fracture strenght after dynamic loading of endodontically treated teeth restored with different post-and-core systems. J Prosthet Dent, Saint Louis, v. 87, n. 4, p. 438-445, Apr. 2002.

55. HO, M-H. et al. Three-dimensional finite element analysis of the effects of post on stress distribuition in dentin. J Prosthet Dent, Saint Louis, v. 72, n. 4, p. 367372, Oct. 1994.

56. HOLLIS, R. A. et al. Post and core, state-of-art. Clin Res Assoc, Provo, v. 22, n. 1, p. 2-3, Nov. 1998.

57. HORNBROOK, D. S.; HASTINGS, J. H. Use of bondable reinforcement fiber for post and core build-up in endodontically treated tooth: maximizing strength and aesthetics. Pract Periodontics Aesthet Dent, Mahwah, v. 7, n.5, p. 33-42, May 1995.

58. HU, Y. H. et al. Fracture resistance of endodontically treated anterior teeth restored with four post-and-core systems. Quintessence Int, Berlin, v. 34, n. 5, p. 349-353, May 2003.

59. İ̃NIGUEZ, I. Odontología restaurativa directa. Usos de RIBBOND para restaurar dientes tratados endodónticamente. Rev ADM, México, v. 57, n. 2, p. 54-58, mar./abr. 2000.

60. ISIDOR, F; ODMAN, P.; BRONDUM, K. Intermittent loading of teeth restored using prefabricated carbon fiber posts. Int J Prosthodont, Lombard, v. 9, n. 2, p. 131-136, Mar./Apr. 1996.

61. JIMENÉZ, M. P. Nueva generaración de munõnes estéticos de resina reforzada com fibras de vidrio. Presentación de um caso clínico. Acta Odont Venez, Caracas, v. 39, n. 3, Dic. 2001.

62. KAIZER, O. B. Avaliação da resistência à fratura de dentes tratados endodonticamente reconstruídos com pinos dentários e com pinos de fibras de polietileno. 2003. 142 f. Dissertação (Mestrado em Odontologia) Faculdade de Odontologia de Bauru, Universidade de São Paulo, Bauru, 2003.

63. KAKAR, M. Post and core fabrication with resin based materials and reinforcing fibers. Disponível em: <http://www.bitein.com/dcp03.htm>. Acesso em: 11 Nov. 2001.

64. KAKEHASHI, Y. et al. A new all-ceramic post and core system: clinical, technical, and in vitro results. Int J Periodontics Restorative Dent, Chicago, v. 18, n. 6, p. 587-593, Dec. 1998.

65. KARNA, J. C. A fiber composite laminate endodontic post and core. Am J Dent, San Antonio, v. 9, n. 5, p. 230-232, Oct. 1996. 
66. KATEBZADEH, N.; DALTON, C.; TROPE, M. Strengthening immature teeth during and after apexification. J Endod, Chicago, v. 24, n. 4, p. 256-259, Apr. 1998.

67. KIMMEL, S. S. Restoration and reinforcement of endodontically treated with a polyethylene ribbon and prefabricated fiberglass post. Gen Dent, Chicago, v. 48, n. 6, p. 700-706, Nov./Dec. 2000.

68. KIMMEL, S. S. Restoration of endodontically treated tooth containg wide or flared canal. N Y St Dent J, Albany, v. 66, n. 10, p. 36-40, Dec. 2000.

69. KING, P. A.; SETCHELL, D. J. An in vitro evaluation of a prototype CFRC prefabricated post developed for the restoration of pulpless teeth. J Oral Rehabil, Oxford, v. 17, n. 6, p. 599-609, Nov. 1990.

70. KURTZ, J. S. et al. Bond strengths of tooth-colored posts, effect of sealer, dentin adhesive, and root region. Am J Dent, San Antonio, v. 16, p. 31A-36A, Sept. 2003. Special issue.

71. LE BELL, A-M. et al. Depth of light-initiated polymerization of glass fiber-reinforce composite in a simulated root canal. Int J Prosthodont, Lombard, v. 16, n. 4, p. 403-408, July/Aug. 2003.

72. LERTCHIRAKARN, V.; PALAMARA, J.; MESSER, H. H. Patterns of vertical root fracture: factors afecting stress distribution in the root canal. J Endod, Chicago, v. 29, n. 8, p. 523-538, Aug. 2003.

73. LIBMAN, W. J.; NICHOLLS, J. I. Load fatigue of teeth restored with cast posts and cores and complete crowns. Int J Prosthodont, Lombard, v. 8, n. 2, p. 15561, Mar./Apr. 1995.

74. LUI, J. L. A technique to reinforce weakened roots with post canals. Endod Dent Traumatol, Copenhagen, v. 3, n. 6, p. 310-314, Dec. 1987.

75. LUI, J. L. Composite resin reinforcement of flared canals using light-transmitting plastic posts. Quintessence Int, Berlin, v. 25, n. 5, p. 313-319, May 1994.

76. MANNOCCI, F.; FERRARI, M.; WATSON, T. F. Intermittent loading of teeth restored using quartz fiber, carbon-quartz fiber, and zirconium dioxide ceramic root canal posts. J Adhes Dent, New Malden, v. 1, n. 2, p. 153-158, Summer 1999.

77. MANNOCCI, F.; SHERRIFF, M.; WATSON, T. F. Three-point bending test of fiber posts. J Endod, Chicago, v. 27, n. 12, p. 758-761, Dec. 2001.

78. MANNOCCI, F. et al. Carbon fiber posts: clinical and laboratory studies. In: INTERNATIONAL SYMPOSIUM S. MARGHERITA LIGURE, 2., 1998, Santa Margherita Ligure, Italy. Proceedings. Santa Margherita Ligure, Italy: [s. ed.], 1998. p. 17-21. 
79. MANNOCCI, F. et al. Confocal and scanning electron microscopic study of teeth restored with fiber posts, metal posts, and composite resins. J Endod, Chicago, v. 25, n. 12, p. 789-794, Dec. 1999.

80. MARCHI, G. M. Resistência à fratura de raízes debilitadas reconstruídas morfologicamente com sistema adesivo associado a pinos intraradiculares. 1997. 104 f. Dissertação (Mestrado em Odontologia) - Faculdade de Odontologia de Piracicaba, Universidade de Campinas, Piracicaba, 1997.

81. MARTINEZ-INSUA, A. et al. Comparison of the fracture resistances of pulpless teeth restored with a cast post and core or carbon-fiber post with a composite core. J Prosthet Dent, Saint Louis, v. 80, n. 5, p.527-532, Nov. 1998.

82. MILLER, T. E. A new material for periodontal splinting and orthodontic retention. Comp Continuing Educ Dent, Lawrenceville, v. 19, n. 6, p. 800-812, July 1993.

83. MILOT, P.; STEIN, S. Root fracture in endodontically treated teeth related to post selection and crown design. J Prosthet Dent, Saint Louis, v. 68, n. 3, p. 428435, Sept. 1992.

84. MITSUI, F. H. O. et al. In vitro study of fracture resistance of bovine roots using different intraradicular post systems. Quintessence Int, Berlin, v. 35, n. 8, p. 612-626, Sept. 2004.

85. MONDELLI, J. Técnicas restauradoras para dentes com tratamento endodôntico. Rev Dent Rest, Bauru, v. 1, n. 3, p. 97-158, jul./set. 1998.

86. MONTENEGRO, J. R. Questões do dia-a-dia. Rev Ass Paul Cirurg Dent, São Paulo, v. 52, n. 2, p. 157, mar./abr. 1998.

87. MONTICELLI, F. et al. Clinical behavior of translucent-fiber posts: a 2-year prospective study. Int J Prosthodont, Lombard, v. 16, n. 6, p. 593-596, Nov./Dec. 2003.

88. MONTICELLI, F. et al. Effects of adhesive systems and luting agents on bonding of fiber posts to root canal dentin. J Biomed Mater Res Part B Appl Biomater, Hoboken, v. 77B, n. 3, p. 195-200. Disponível em: http://wwww3.interscience.willey.com/cgi-bin/fulltext/112131651/PDFSTART. Acesso em: 7 mar. 2006.

89. MORGANO, S. M.; RODRIGUES, A. H. C.; SABROSA, C. E. Restoration of endodontically treated teeth. Dent Clin North Am, Philadelphia, v. 48, n. 2, p. 397-416, Apr. 2004.

90. NAUMANN, M.; PREUSS, A.; ROSENTRITT, M. Effect of incomplete crown ferrules on load capacity of endodontically treated maxillary incisors restored with fiber posts, composite build-ups, and all-ceramic crowns: An in vitro evaluation after chewing simulation. Acta Odont Scand, Oslo, v. 64, n. 1, p. 31-36, Feb. 2006. 
91. NAUMANN, M.; BLANKENSTEIN, F.; DIETRICH, T. Survival of glass fiber reinforced composite post restorations after 2 years - an observational clinical study. J Dent, Bristol, v. 33, n. 4, p. 305-312, Apr. 2005.

92. NEWMAN, M. P. et al. Fracture resistance of endodontically treated teeth restored with composite posts. J Prosthet Dent, Saint Louis, v. 89, n. 4, p. 360367, Apr. 2003.

93. O'KEEFE, K. L.; MILLER, B. H.; POWERS, J. M. In vitro tensile bond strenght of adhesive cements to new post materials. Int J Prosthodont, Lombard, v. 13, n. 1, p. 47-51, Jan./Feb. 2000.

94. OTTL, P. et al. Fracture characteristics of carbon fiber, ceramic an non-palladium endodontic post systems at monotonously increasing loads. J Oral Rehabil, Oxford, v. 29, n. 2, p. 175-183, Feb. 2002.

95. OURIQUE, S. A. M. Colagem de fragmento dentário utilizando reforço intracanal de fibras cerâmicas flexíveis (GlasSpan). Rev Paul Odont, São Paulo, v. 21, n. 2, mar./abr. 1999.

96. OURIQUE, S. A. M. Cimento resinoso e compósito reforçados por fibras cerâmicas flexíveis em núcleo intra-canal. Rev Bras Prót Clín Lab, Curitiba, v. 2, n. 7, p. 41-47, jun./jul. 2000.

97. OURIQUE, S. A. M. Fibras cerâmicas flexíveis na odontologia estética. In: LIMBERTE, M. S.; MONTENEGRO, J. R. (Coord.). Estética do sorriso - Arte e ciência. São Paulo: Ed. Santos, 2003. Cap. 18, p. 263-289.

98. PERDIGÃO, J.; GERALDELI, S.; LEE, I. K. Push-out bond strengths of toothcolored posts bonded with different adhesive systems. Am J Dent, San Antonio, v. 17, n. 6, p. $422-426$, Dec. 2004.

99. PEST, L. B. et al. Adhesive post-endodontic restorations with fiber posts : pushout tests and SEM observations. Dent Mater, Copenhagen, v. 18, n. 8, p. 596602, Dec. 2002.

100. PITEL, M. L.; HICKS, N. L. Evolving technology in endodontic posts. Comp Continuing Educ Dent, Lawrenceville, v. 24, n. 1, p. 13-28, Jan. 2003.

101. PONTIUS, O.; HUTTER, J. W. Survival rate and fracture strength of incisors restored with different post and core systems and endodontically treated incisors without coronoradicular reinforcement. J Endod, Chicago, v. 28, n, 10, p. 710715, Oct. 2002.

102. PURTON, D. G.; LOVE, R. M. Rigidity and retention of carbon fiber versus stainless steel root canal posts. Int Endod J, Oxford, v. 29, n. 1, p. 262-265, July 1996.

103. PURTON, D. G.; PAYNE, J. A. Comparison of carbon fiber and stainless steel root canal posts. Quintessence Int, Berlin, v. 27, n. 2, p. 93-97, Feb. 1996. 
104. PURTON, D. G.; CHANDLER, N. P.; QUALTROUGH, A. J. Effect of thermocycling on the retention of glass-fiber root canal posts. Quintessence Int, Berlin, v. 34, n. 5, p. 366-369, May 2003.

105. QUALTROUGH, A. J. E.; CHANDLER, N. P.; PURTON, D. G. A comparison of the retention of tooth-colored posts. Quintessence Int, Berlin, v. 34, n.3, p. 199201, Mar. 2003.

106. RAYGOT, C. G.; CHAI, J.; JAMESON, L. Fracture resistance and primary failure mode of endodontically treated teeth restored with a carbon fiber-reinforced resin post system in vitro. Int J Prosthodont, Lombard, v. 14, n.2, p. 141-145, Mar./Apr. 2001.

107. REID, L. C.; KAZEMI, R. B.; MEIERS, J. C. Effect of fatigue testing on core integrity and post microleakage of teeth restored with different post systems. J Endod, Chicago, v. 29, n. 2, p. 125-131, Feb. 2003.

108. RING, M. E. História ilustrada de la odontologia. Barcelona: Doyma, 1989. $320 \mathrm{p}$.

109. ROVATTI, L.; MASON, P. N.; DALLARI, A. New researches on fibre carbon posts. Minerva Stomatol, Torino, v. 43, n. 12, p. 17-20, Dic. 1994.

110. ROVATTI, L., MASON, P. N., DALLARI, A. The esthetical endondontic posts. In: INTERNATIONAL SYMPOSIUM S. MARGHERITA LIGURE, 2., 1998, Santa Margherita Ligure, Italy. Proceedings. Santa Margherita Ligure, Italy: [s. ed.], 1998. p. $12-16$.

111. RUDO, D. N.; KARBHARI, M. E. Physical behaviors of fiber reinforcement as applied to tooth stabilization. Dent Clin North Am, Philadelphia, v. 43, n. 1, p. 735, Jan. 1999.

112. SAHAFI, A. Retention and failure morphology of prefabricated posts. Int $\mathbf{J}$ Prosthodont, Lombard, v.17, n. 3, p. 307-312, May/June 2004.

113. SAHAFI, A. et al. Bond strength of resin cement to dentin and to surface-treated posts of titanium alloy, glass fiber, and zirconia. J Adhes Dent, New Malden, v. 5, n. 2, p. 153-162, Summer 2003.

114. SAUPE, W. A.; GLUSKIN, A. H.; RADKE, R. A. A comparative study of fracture resistance between morphologic dowel and cores and a resin-reinforced dowel system in the intraradicular restoration of structurally compromised roots. Quintessence Int, Berlin, v. 27, n. 7, p. 483-491, July 1996.

115. SHILLINGBURG, H. T.; KESSLER, J. C. Príncipios da restauração dos dentes tratados endodonticamente. In: Restaurações protéticas dos dentes tratados endodonticamente. 2.ed. São Paulo: Quintessence, 1991. Cap. 1, p. 13-44. 
116. SIDOLI, G. E.; KING, P. A.; SETCHELL, D. J. An in vitro evaluation of a carbon fiber-based post core system. J Prosthet Dent, Saint Louis, v. 78, n. 1, p. 5-9, July 1997.

117. SILVA E SOUZA JÚNIOR., M. H. et al. Reconstrução de dentes tratados endodonticamente. In: Odontologia estética: fundamentos e aplicações clínicas. Restaurações indiretas sem metal: resinas compostas e cerâmica. São Paulo: Ed. Santos, 2001. Cap. 4, p. 29-46.

118. SILVERSTEIN, W. H. The reinforcement of weakened pulpless teeth. $\mathbf{J}$ Prosthet Dent, Saint Louis, v. 14, n. 2, p. 372-381, Mar./Apr. 1964.

119. SIRIMAI, S.; RIIS, D. N.; MORGANO, S. M. An in vitro study of the fracture resistance and the incidence of vertical root fracture of pulpless teeth restored with six post-and-core systems. J Prosthet Dent, Saint Louis, v. 81, n.3, p. 262269, Mar. 1999.

120. SOARES, J. C. F. Resistência à fratura de raízes enfraquecidas reconstruídas com sistemas restauradores adesivos. $1999.101 \mathrm{f}$. Dissertação (Mestrado em Odontologia) - Faculdade de Odontologia de Bauru, Universidade de São Paulo, Bauru, 1999.

121. SORENSEN, J. A.; ENGELMAN, M. J. Ferrule design and fracture resistance of endodontically treated teeth. J Prosthet Dent, Saint Louis, v. 63, n. 5, p. 529536, May 1990.

122. SORENSEN, J. A.; ENGELMAN, M. J. Effect of post adaptation on fracture resistance of endodontically treated teeth. J Prosthet Dent, Saint Louis, v. 64, n. 4, p. 419-424, Oct. 1990.

123. SORENSEN, J. A.; MARTINOFF, J. T. Clinically significant factors in dowel design. J Prosthet Dent, Saint Louis, v. 52, n.1, p.28-35, July 1984.

124. SORENSEN, J. A.; MARTINOFF, J. T. Intracoronal reinforcement and coronal coverage: a study of endodontically treated teeth. J Prosthet Dent, Saint Louis, v. 51, n. 6, p. $780-784$, June 1984.

125. SORNKUL, E.; STANNARD, J. G. Strength of roots before and after endodontic treatment and restoration. J Endod, Chicago, v. 18, n. 9, p. 440-443, Sept. 1992.

126. STANDLEE, J. P. et al. Analysis of stress distribution by endododontic posts. Oral Surg Oral Med Oral Pathol Oral Radiol Endod, Saint Louis, v. 33, n. 6, p.52-60, June 1972.

127. STEWARDSON, D. A. Non-metal post systems. Dent Update, Guildford, v. 28, n. 7, p. 326-336, Sept. 2001.

128. STOCKTON, L. W. Factors affecting retention of post systems: a literature review. J Prosthet Dent, Saint Louis, v. 81, n. 4, p. 380-385, Apr. 1999. 
129. STRUB, J.R.; PONTIUS, O.; KOUTAYAS, S. Survival rate and fracture strength of incisors restored with different post and core systems after exposure in the artificial mouth. J Oral Rehabil, Oxford, v. 28, n. 2, p. 120-124, Feb. 2001.

130. TERRY, D. A.; TRIOLO, P. T. Fabrication of direct fiber-reinforced posts: a structural design concept. J Esthet Restor Dent, Hamilton, v. 13, n.4, p. 228240, July 2001.

131. TJAN, A. H. L.; WHANG, S. B. Resistance to root fracture of dowel channels with various thickness of buccal dentin walls. J Prosthet Dent, Saint Louis, v. 53, n. 4, p. 496-500, Apr.1985.

132. TRABERT, K. C.; CAPUTO, A. A.; ABOU-RASS, M. Tooth fracture: a comparison of endodontic and restorative treatments. J Endod, Chicago, v. 4, n. 11, p. 341-345, Nov. 1978.

133. TROPE, M.; RAY, H. L. Resistance to fracture of endodontically treated roots. Oral Surg Med Oral Pathol Oral Radiol Endod, Saint Louis, v. 73, n. 1, p. 99102, Jan. 1992.

134. TROPE, M.; MALTZ, D.O.; TRONSTAD, L. Resistance to fracture of restored endodontically treated teeth. Endod dent Traumatol, Copenhagen, v. 1, n. 3, p. 108-111, June 1985.

135. USUMEZ, A. et al. Microleakage of endodontically treated teeth with different dowel systems. J Prosthet Dent, Saint Louis, v. 92, n. 2, p. 163-169, Aug. 2004.

136. VANO, M. et al. The adhesion between fibre posts and composite resin cores: the evaluation of microtensile bond strength following various surface chemical treatments to posts. Int Endod J, Oxford, v. 39, n. 1, p. 31-39, Jan. 2006.

137. VICHI, A. et al. An SEM evaluation of several adhesive systems used for bonding fiber posts under clinical conditions. Dent Mater, Copenhagen, v. 18, n. 7, p. 459-502, Sept. 2002.

138. XIBLE, A. A. Avaliação da resistência ao cisalhamento de três sistemas de núcleos intra-radiculares. 2000. 92 f. Dissertação (Mestrado em Odontologia) - Faculdade de Odontologia de Bauru, Universidade de São Paulo, Bauru, 2000.

139. YOLDAS, O.; TAYFUN, A. Microhardness of composites in simulated root canals cured with light transmitting posts and glass-fiber reinforced composite posts. J Endod, Chicago, v. 31, n. 2, p. 104-106, Feb. 2005. 
ABSTRACT 


\section{ABSTRACT \\ EVALUATION OF FRACTURE RESISTANCE OF TEETH WITH FLARED ROOT CANALS RECONSTRUCTED WITH PREFABRICATED GLASS FIBER POSTS (ASSOCIATED WITH ACCESSORY POSTS OR FIBER STRIPS) OR WITH ANATOMIC POSTS.}

This study evaluated the fracture resistance of endodontically treated teeth reconstructed with cast metallic posts or different restorative procedures using glass fiber posts. Fifty canines were sectioned at the cementoenamel junction, endodontically treated and fixated in acrylic resin blocks. Teeth were randomly divided into five groups (10 specimens each): 1) cast metallic post (control group); 2) conventional glass fiber post FibreKor n. 2 (1.25mm diameter); 3) glass fiber post surrounded by glass fiber strips (Interlig); 4) glass fiber post combined with accessory glass fiber posts (Reforpin); 5) anatomic post (glass fiber post covered with low-viscosity composite resin (Filtek Flow). Root canal preparation in the five groups simulated roots with wide root canals and was performed by the step-down technique (two steps). This preparation was performed with a diamond bur n. 1016HL (1.8-mm diameter), which penetrated into the root canal in 10mm (total depth of root canal preparation). The cervical step was prepared with 5-mm depth with a diamond bur n. 3017HL (2.5-mm diameter). Posts were luted with the adhesive system Scotchbond Multi-Uso Plus and resin cement RelyX CRA. After fabrication of the coronal portion of posts (standardized with aid of polypropylene templates) with composite resin Enforce-Core, a metallic full crown cast in nickel-chromium alloy was cemented on it. Specimens were stored in distilled water at $37^{\circ} \mathrm{C}$ for 24 hours and submitted to compressive fracture resistance test in a universal testing machine Kratos. Load was applied at $135^{\circ}$ to the root long axis, at a crosshead speed of $0.5 \mathrm{~mm} / \mathrm{min}$. Fracture resistance values were the following, in decreasing order: Group 1 - 110.85kgf; Group 4 - 93.88kgf; Group 5 - 89.34kgf; Group 3 - 79.07kgf; Group 2 - 76.04kgf; statistical analysis (ANOVA and Tukey) revealed statistically significant difference $(\mathrm{p}<0.05)$ between groups 1 and 2 and between groups 1 and 3 . Concerning the pattern of fracture, all roots in group 1 presented fracture $(60 \%$ at the middle third); groups 2 and 4 presented $40 \%$ of fractures at the cervical root third and 30 to $40 \%$ of failure at the coronal portion of the post; group 3 demonstrated predominance of fracture at the cervical root third (60\%); in group 5, 50\% of failures occurred at the coronal portion of the post. 
